
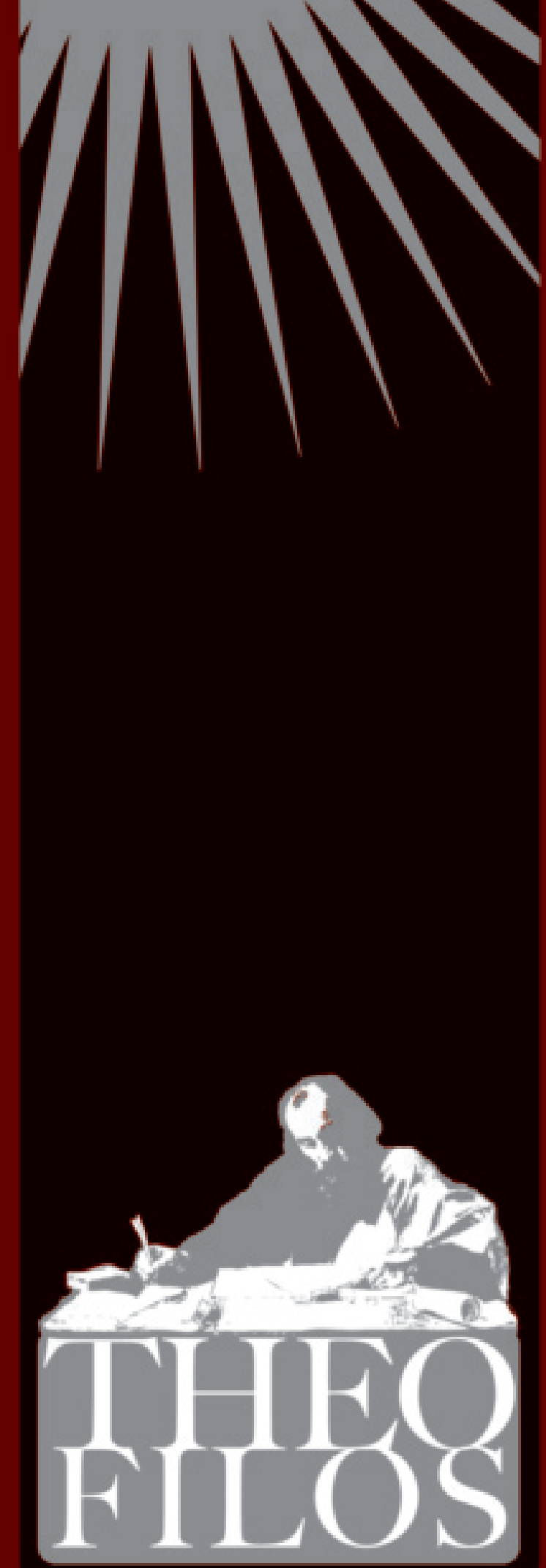

Supplement

VOL. I2 NR. I 2020 
Theofilos is a Nordic peer reviewed open access journal devoted to the study of Theology, Philosophy and Culture and their neighbouring disciplines. The overarching purpose of the journal is to present, analyse, and discuss the truth and relevance of the Christian faith.

Theofilos is published by NLA University College (Kristiansand, Norway) in partnership with Johannelund School of Theology (Uppsala, Sweden). There are usually two issues per year, and occasionally also theme issues (Theofilos Supplement).

Each issue of Theofilos contains five independent sections: editorials (intro), peer reviewed articles (academia), critical discussions and analysis (forum), book reviews (biblos), and relevant information (nota bene). Writers are welcome to contribute manuscripts to academia or forum and book reviews for biblos. For guidelines, see www.theofilos.no or inside back cover.

Theofilos är en nordisk fackgranskad open access tidskrift för studiet av teologi, filosofi och kultur och närliggande områden. Tidskriften utkommer regelbundet två gånger per år och tillfälligtvis med temanummer (Theofilos Supplement).

Dess övergripande syfte är att presentera, analysera och diskutera den kristna trons sanning och relevans.

Tidskriften publiceras av NLA Høgskolen (Kristiansand, Norge) i samarbete med Johannelunds teologiska högskola (Uppsala, Sverige).

Varje nummer innehåller fem oberoende avdelningar: ledarartiklar (intro), fackgranskade artiklar (academia), kritiska diskussioner och analyser (forum), bokrecensioner (biblos) och relevant information (nota bene).

Skribenter är välkomna att bidra med manus till academia och forum samt bokrecensioner till biblos. För riktlinjer, se www.theofilos.no eller insidan av omslagets baksida.
Theofilos er et nordisk fagfellevurdert open access tidsskrift for studier av teologi, filosofi og kultur og beslektede fagfelt. Tidsskriftet utgis fast to ganger årlig, og iblant med ekstra temanummer (Theofilos Supplement). Tidsskriftets overordnede hensikt er å presentere, analysere og drøfte den kristne troens sannhet og relevans. Det publiseres av NLA Høgskolen (Kristiansand, Norge) i samarbeid med Johannelunds teologiska högskola (Uppsala, Sverige).

Hvert nummer inneholder fem uavhengige avdelinger: lederartikler (intro), fagfellevurderte artikler (academia), kritiske diskusjoner og analyser (forum), bokanmeldelser (biblos) og relevant informasjon (nota bene)

Skribenter er velkomne til å bidra med manus til academia og forum, samt med bokanmeldelser til biblos. For retningslinjer, se www.theofilos.no eller innsiden av omslagets bakside.

\section{Editorial board/Redaksjon/Redaktion}

Lars Dahle (Chief Editor / ansvarlig redaktør), NLA Høgskolen, Norge

Stefan Lindholm (Editor / redaktör), Johannelunds teologiska högskola, Sverige

Bjørn Hinderaker (Book Editor / bokredaktør), NLA Høgskolen, Norge

Kjell O. Lejon, Linköpings Universitet / Johannelunds teologiska högskola, Sverige

Margunn Serigstad Dahle, NLA Høgskolen, Norge

Stefan Gustavsson, NLA Høgskolen, Norge / Johannelunds

teologiska högskola, Sverige

Terje Skjerdal, NLA Høgskolen, Norge

\section{Editorial Advisory Panel/Redaksjonsråd/Redaktionsråd}

Knut Alfsvåg, VID vitenskapelige høgskole, Stavanger, Norge Jeppe Bach Nikolajsen, MF vitenskapelig høyskole for teologi, religion og samfunn, Norge

\section{Theofilos / www.theofilos.no}

ISSN 2703-7037 (online)

ISSN 1893-7969 (print / trykt utg.)

International license: CC BY-NC 4.0

Registration (DOI): NLA University College

Production: Förlaget Boken

Publication: Damaris Norge AS

Print: Synkron Media AS
Tomas Bokedal, NLA Høgskolen, Norge / Divinity and Religious Studies, University of Aberdeen, United Kingdom Leif Erikson, Åbo Akademi, Finland

Jens Bruun Kofoed, Fjellhaug internationale høgskole, Norge/ Danmark

Paul Hemeren, Skövde Högskola, Sverige

Torbjörn Johansson, Församlingsfakulteten, Sverige

Per Landgren, Oxford University, United Kingdom

Torbjörn Larspers, Johannelunds Teologiska Högskola, Sverige

Vesa Ollilainen, Åbo Akademi, Finland

Atle Ottesen Søvik, MF vitenskapelig høyskole for teologi,

religion og samfunn, Norge

Solveig Reindal, NLA Høgskolen Bergen, Norge

Morten Sager, Göteborgs universitet, Sverige

James Starr, Johannelunds Teologiska Högskola, Sverige

Ralph Vaags, Universitetet i Agder, Norge

Chris Wales, NLA Høgskolen Gimlekollen, Norge

https://www.nla.no/forskning/2publikasjoner2/tidsskriftet-theofilos/ http://www.johannelund.nu/theofilos/

Theofilos, NLA Høgskolen, Bergtoras vei 120, NO-4633 Kristiansand, Norway.

Theofilos, Johannelunds teologiska högskola, Heidenstamsgatan 75, SE-754 27 Uppsala, Sweden.

For questions, please contact red@theofilos.no.

För frågor, var vänlig kontakta red@theofilos.no.

For spørsmål, vennligst kontakt red@theofilos.no.

Theofilos utges med bidrag från Samfundet Pro Fide et Christianismo, förvaltare av kyrkoherde Nils Henrikssons Stiftelse. 


\section{Welcome to the first open access issue of Theofilos}

\section{Dear Readers!}

With many others, you may be reading this on a paper - still warm off the printer - or on a digital screen in some form or other. Indeed, most of you are probably not holding a physical copy of Theofilos in your hands as you are reading these words!

It is now a universal trend that academic as well as popular texts are increasingly being published on various digital platforms. The editorial board of Theofilos decided to join this trend, and from this issue onwards we begin digital publication. The transition to open access was led by our wise and patient Chief Editor, Lars Dahle, and has involved new and fascinating insights into the nature and ethics of academic publishing.

A consequence of all this hard work is that the publication dates are dramatically delayed in 2020. Still, in view of the attractive new format and the ongoing relevant content, we think it was worth waiting! Among other things, all articles (in due time also for back issues) now have their unique DOI-number. This is a fantastic search tool for academics, and this function was a strong motivator to begin the process towards open access publishing.

We are therefore proud and happy to be able to present Theofilos as a modern journal in the best sense of the word - being able to moderate its message in tune with the contemporary context and thereby reaching more readers than the limited paper edition was ever able to do.

I hasten to add that for those who would like to continue to read the paper edition and I am one of them! - it will be printed in a very limited edition and distributed to strategically chosen libraries in Scandinavia. See list on the homepage (www.theofilos.no). This is made possible with financial support from Pro Fide et Christanismo.

In the journey towards becoming an online journal, we have also examined the ethical guidelines of Theofilos, and we will continue to work towards ensuring a high quality in our editorial and peer review processes. Another important focus area in the near and far future is online marketing in various ways, so that news about upcoming issues and articles, and key related physical and digital events, will be made known more widely.

Let me also add that from the end of 2020 I will continue my work as co-editor for Theofilos as part of my role as Associate Professor in Systematic Theology at Johannelund School of Theology. Thus, the institutional partnership between NLA University College and Johannelund has been strengthened. I look forward to benefit from the collegia of both these fine institutions in our ongoing editorial work with Theofilos. Let me add that Lars' combination of enthusiasm and wisdom in Christ is important not only to the existence and development of Theofilos but to much more besides. I am grateful to continue to be his co-worker.

On behalf of both of us as Editors, I would also like to thank the infatigable Sune Jäderberg at Förlaget Boken who has been responsible for the production and layout of Theofilos since our humble beginnings in 2009. We appreciate his meticulous care for details and his great sense of humor. Kjetil Fyllingen, our excellent web consultant at Damaris Norge, established our new website in June 2019, and has now facilitated our transition to open access with a steady hand.

This first open access issue is a Supplement issue based on the Veritas Research Symposium at the NLA Gimlekollen Campus in Kristiansand, Norway, in October 


\section{Theofilos}

A Nordic open access journal in Theology, Philosophy and Culture

Published by NLA University College - in partnership with Johannelund School of Theology

Available at www.theofilos.no

2018. The theme is "Science, Natural Theology, and Christian Apologetics". It has been edited by our Chief Editor, our Book Editor Bjørn Hinderaker, and with Peter S. Williams as our Guest Editor. We are truly grateful for Pete's assistance in editing all the texts and for his own substantial contributions, and we also extend our thanks to all the other contributors. So, without further ado, I will let our Guest Editor introduce the exciting content of this first open access issue of Theofilos.

Tolle et lege!

Stefan Lindholm, Editor

Uppsala, Sweden, December 2020

\section{Introducing the Theofilos Supplement issue on Science, Natural Theology, and Christian Apologetics}

In early 2018, I proposed an annual research 'symposium' to be held at the NLA Gimlekollen Campus (with academic presentations and discussion, but with coffee replacing the traditional Greek wine). I was delighted to see NLA colleagues run with the concept, such that the Veritas Research Symposium launched in October 2018 now is an annual event at the campus in Kristiansand, Norway. The symposium's focus is research on challenges, themes, and issues in Christian apologetics and related missiological, theological and philosophical areas. The symposium is closely linked to the annual Norwegian Veritas Conference. ${ }^{1}$

The theme chosen for the inaugural symposium was Science, Natural Theology, and Christian Apologetics. This is an exciting topic for interdisciplinary research of key relevance to contemporary culture. Once we had a view of the proposed papers, it became clear that they fell naturally into three sub-topics which we used to structure the Symposium: 'Issues in Genesis', 'Issues in Natural Theology' and 'Issues in Contemporary Popular Culture'.

Papers presented at the 2018 symposium were subsequently read and commented upon by the co-editors of this Supplement issue of Theofilos (Chief Editor Lars Dahle, Book Editor Bjørn Hinderaker and myself as Guest Editor), before being revised by the contributors and submitted to the standard double blind peer review process.

\section{The academia section}

The editorial and the peer review procedures resulted in seven academic articles from the Symposium. The articles cover the three topical areas mentioned above and represent a fascinating spectrum of positions and perspectives.

\section{Issues in Genesis}

- Jens Bruun Kofoed (Fjellhaug International University College):

'Approaching Genesis and science: Hermeneutical principles and a case study'

- Gunnar Innerdal (NLA University College, Bergen): 'The origin of sin - in dialogue with natural science'

\section{Issues in Natural Theology}

- Knut-Willy Scether (Volda University College): 'The apologetic fruitfulness of a revised natural theology'

- Atle Søvik (MF Norwegian School of Theology, Religion and Society, Oslo): 'How to formulate the fine-tuning argument for the existence of God?'

- Steinar Thorvaldsen (UiT, The Arctic University of Norway, Tromsø): 'Intelligent design and natural theology' 


\section{Issues in Contemporary Popular Culture}

- Peter S. Williams (NLA University College, Kristiansand): 'Scientific Rebuttals to "Ancient Aliens" as Popular Alternatives to Biblical History'

- Margunn Serigstad Dable (NLA University College, Kristiansand) and Ingvild Thu Kro (NLA University College, Kristiansand): “Unraveling the Mystery": Assessing The Big Bang Theory as a Secular Fictional Universe'

\section{The other sections}

This special Supplement issue also presents a selection of thematically relevant contributions in the usual forum, biblos and nota bene sections of Theofilos.

We are especially pleased to have received permission to include previously published articles by Oxford emeritus professor John Lennox and Genesis specialist C. John Collins. As keynote speaker at the Veritas Conference in 2018, Lennox visited our Symposium with an inspirational greeting. The essay from Collins highlights some significant, and maybe unexpected, contributions from Francis Schaeffer and C.S. Lewis, influential Christian apologists in the 20th century.

\section{forum}

- Peter S. Williams (NLA University College, Kristiansand), 'Natural Theology and Science in Contemporary Apologetic Context: An Overview'

- John Lennox (University of Oxford), 'Science and Faith: Friendly Allies, Not Hostile Enemies' (Reprinted with permission)

- C. John ('Jack') Collins (Covenant Theological Seminary, St. Louis), 'Freedoms and Limitations: C. S. Lewis and Francis Schaeffer as a Tag Team' (Reprinted from Firstfruits of a New
Creation: Essays in Honor of Jerram Barrs with permission)

- Bjørn Hinderaker (NLA University College, Kristiansand) and Lars Dahle (NLA University College, Kristiansand), 'Genesis 1-3 as a Worldview Story: Exploring the Story and Its Worldview with Francis A. Schaeffer, C. S. Lewis, and C. John Collins'

\section{biblos}

- 'Four Dozen Key Resources on Apologetics and Natural Theology in an Age of Science', as curated and annotated by Peter S. Williams (NLA University College, Kristiansand).

\section{nota bene}

- Iain Morris (Kharis Productions), 'How convincing is the case for God? The "Finnes Gud?" television series offers you the chance to assess it!'

- Finnes Gud? and The God Question for Starters

\section{A final note}

The editorial team wish to record our thanks to everyone involved, both with the 2018 Veritas Research Symposium and with the production of this special theme issue of Theofilos.

We trust that this Supplement edition of Theofilos will provide an introduction to and overview of key issues in the interdisciplinary field of Science, Natural Theology and Christian Apologetics, offering some fresh perspectives on these issues, whilst stimulating further reflections, a continued conversation, and future contributions on these themes.

\section{Peter S. Williams}

Southampton, December 2020

Guest Editor

1 See https://veritaskonferansen.no/. 


\title{
Approaching Genesis and Science: Hermeneutical Principles and a Case Study
}

\author{
Jens Bruun Kofoed \\ Professor of Old Testament Exegesis and Theology \\ Fjellhaug International University College, Oslo, Norway \\ jbk@dbi.edu \\ The unlike is joined together, \\ and from differences results the most beautiful harmony, \\ and all things take place by strife. \\ Heraclitus, Fragments 126
}

\begin{abstract}
The purpose of the present paper/article is to discuss the hermeneutic principles used in reading 'God's two books,' creation and Scripture, together. The first part of the paper outlines and recommends the hermeneutical principles and procedures used by Galileo Galilei (1564-1642) in the Copernican controversy conflict between the Church and (Christian) scientists on the right to interpret scripture and how to do this informed by science. In the second part of the paper these principles and procedures are applied to a case study on the apparent conflict between the doctrine on common descent in evolutionary biology and the traditional understanding of Adam and Eve as the sole progenitors of humankind. A recent attempt by Joshua Swamidass to synthesize mainstream evolutionary theory with a high-view interpretation of Scripture is commended for allowing the scientific consensus to prompt a reconsideration of the traditional 'spinal cord reflex' against evolutionary understandings of humankind's descent among Evangelical scholars. For the same reason it is recommended that sandboxes for interpretative and hypothesizing experimentation are created in both the academy and the church in order for various syntheses between interpretations of Scripture and scientific theories to be discussed without inquisitory strategies hindering a healthy and constructive debate.
\end{abstract}

Keywords: Genesis; Evolution; Science; Adam; Creation 


\section{God's Two Books}

The relationship between interpretations of Genesis and (pre)scientific theories has always occupied Christian scholars. ${ }^{1}$ As early as the third century $\mathrm{AD}$ Anthony the Great wrote that 'my book is the created nature, a one always at my disposal whenever I want to read God's words,' 2 and among the Church Fathers explicit mentioning of God's two books, Scripture and creation, can be found in the writings of Basil the Great (c.329-379), Gregory of Nyssa (c.335-395), Augustine (354-430), John Cassian (360-430/435), John Chrysostom (347-407), Ephrem the Syrian (c.306-373) and Maximus the Confessor (c.580-662). Augustine, for example, regards creation as 'a great book'3 and describes how God, who mercifully clothed naked Adam and Eve after the fall with a skin, likewise stretched out the 'firmament of your book' like a skin in order for us to 'read' about his mercy. ${ }^{4}$ In the Middle Ages references to the two-books metaphor may be found in the writings of, among others, Bernard of Clairvaux (1090-1153), Hugh of St. Victor, (10961141), St. Bonaventure (1217-1274), St. Thomas Aquinas (1224-1274), Thomas of Chobham (c. 1255-1327), Dante Alighieri (1265-1321), Thomas of Kempis (1380-1471) and Raymond of Sebond (c. 1385-1436), and though the reformer Martin Luther did not use the metaphor itself, he clearly regarded Scripture and creation God's twin revelations. In his commentary on Gal 4:9 he writes, for example, that ' $[\mathrm{t}]$ here is a twofold knowledge of God: the general and the particular. All men have the general knowledge, namely, that God is, that He has created heaven and earth, that $\mathrm{He}$ is just, that $\mathrm{He}$ punishes the wicked, etc. But what God thinks of us, what He wants to give and to do to deliver us from sin and death and to save us - which is the particular and the true knowledge of God - this men do not know' (Luther 1963, 399; WA 15,608). ${ }^{5}$ Nature and history are, Luther argues elsewhere, larvae Dei God's masks' (WA 17,2,192; 40,1,174). ${ }^{6}$

The purpose of the present paper is not to track the pedigree of the concept of God's two books, but to discuss the hermeneutic principles used in 'reading' them together. The first part of the paper outlines and recommends the principles for bringing the two 'books' together used by Galileo Galilei (1564-1642). In the second part of the paper the principles are applied to a case study on the apparent conflict between the doctrine on common descent in evolutionary biology and the traditional understanding of Adam as the sole progenitor of humankind.

\section{The Renaissance as a Hermeneutical Turning Point}

In the Patristic and Middle Ages, Giuseppe Tanzella-Nitti argues, the idea of dialectic opposition between the two books is unknown: 'Authors are not concerned about showing or demonstrating their "harmony," in the contemporary meaning of the word. Rather, they want to show their common dignity as divine revelation and their role to provide mankind with a true knowledge of the unique God [...] The two Books are discussed and compared without any need for healing or rectifying any conflict'. The transition to the Renaissance, however, is a hermeneutical turning point. 'The development of natural studies and experimental observations carried out in the late Renaissance,' Tanzella-Niti continues, 
'introduced the idea that we can approach the world of the divine without the mediation of sacred Scripture, of theology or scholastic philosophy, and of course without the mediation of any Church' (Tanzella-Niti 2004, 14; quote from online version).

The hermeneutic picture painted by Tanzella-Nitti is slightly distorted, however, since 'natural studies and experimental observations' was practised before the Renaissane, and already Augustine, for example, saw tensions between God's two books and made efforts to harmonize them. Besides, outside the authority of the Church, such pre-scientific exercises were indeed practised in a 'secular' or 'pagan' setting, so the situation described by Tanzelli-Nitti only applies to pre-scientists working under the auspice and authority of the Church.

Tanzelli-Nitti is correct to argue, however, that, though God, for the Renaissance scientists, were still the author of the book of Nature, the concept of Nature as a book became more and more secularized and separated from its original theological setting with two important consequences. Firstly, from being a book 'all men' could read, reading the book of Nature now became a matter for scientists, as remarked, famously, by Galileo Galilei in his Il Saggiatore from 1623:

Philosophy is written in this grand book, the universe, which stands continually open to our gaze. But the book cannot be understood unless one first learns to comprehend the language and read the letters in which it is composed. It is written in the language of mathematics, and its characters are triangles, circles and others geometric figures without which it is humanly impossible to understand a single word of it; without these, one wanders about in a dark labyrinth (Galilei 1968, 232).

Secondly, the alienation of the book of Nature permitted readings that eventually brought it into conflict with the reading of Scripture. And it was none other than Galilei himself, of course, who became the centerpiece of the first significant conflict between the Church and (Christian) scientists on the right to interpret scripture and how to do this informed by science. ${ }^{7}$

Our interest is not so much in the theological and political specifics of that conflict, but, again, in how the readings of the two books were brought to bear on one another, and how (if at all) this may be of help in the next and still on-going significant conflict between readings of the two books, namely between creationist interpretations of Scripture and scientific theories of evolution.

A 'creationist,' at a broad level, is, according to Stanford Encyclopedia of Philosophy:

someone who believes in a god who is absolute creator of heaven and earth, out of nothing, by an act of free will. Such a deity is generally thought to be 'transcendent' meaning beyond human experience, and constantly involved ('immanent') in the creation, ready to intervene as necessary, and without whose constant concern the creation would cease or disappear. Christians, Jews, and Muslims are all Creationists in this sense (Ruse 2018).

Though the Encyclopedia proceeds to define creationists very narrowly as 'Young Earth Creationists,' the term is not used by the present author (nor by, for example, old earth creationists or proponents of evolutionary creationism) in 
this narrow definition. In its present use it spans positions from theistic or evolutionary creationism to young earth creationism, that is, from positions that read the Biblical text literalistically and in conflict with evolutionary biology to approaches that allow for non-literalistic interpretations that may be compatible with evolutionary understandings of the origins of the universe and life.

\section{Concordism}

The crucial question in bringing science and faith together is not so much whether God has written two books but how we should understand the relationship between them in our search for answers to the questions of origin. The various positions are often described in terms of a continuum from concordism to non-concordism with 'concordism' covering approaches that see a concord or agreement between what the two books have to say about the origin of cosmos, life, species and man, and non-concordism' expressing views that consider the two books as two separate sources of knowledge with no overlap. 8

Hugh Ross and Kenneth Samples, in Old Earth or Evolutionary Creation?, have a useful model of the continuum from 'hard' concordant via 'soft' concordant and non-concordant approaches to 'hard' non-concordant ones (Keathley, Stump, and Aguirre 2017, 22-24). According to the 'hard' non-concordant model God's two books are two separate sources for knowledge with no overlap whatsoever. Since they address different domains (of faith and science), they may, and indeed do, according to this view, provide different explanations of life's origin without these explanations contradicting each other. According to the 'soft' nonconcordant model there is a minimal overlap between what the two sources of knowledge addresses. Proponents of the two non-concordant models typically argue, therefore, that Scriptural creation theology and evolutionary biology are two different and equally true explanations on the questions of origin. Most evolutionary creationists prefer this complementary model and acknowledge, on the one hand, that Scripture states explicitly that the cosmos had a beginning, but also hold, on the other hand, that Scripture nowhere explains scientifically how life began. Furthermore, proponents of both non-concordant models have a 'deistic' tendency to downplay God's supernatural intervention and a corresponding emphasis on seeing God's creative activity as a direction of the evolutionary processes. For the same reason proponents of these models - in particular those who favor the 'hard' non-concordant model - argue that it is science, not Scripture, that answers our questions of origin.

Over against this non-concordant approach stands two concordant models which both view the relationship between Bible and science as a 'fusion' or an 'interaction.' The first model, also known as 'hard' concordism, attribute scientific meaning to all Biblical texts referring to creation and holds that all scientific observations have theological implications. Proponents of this model - especially young-earth creationists - typically argue that it is possible to find scientific information in the Bible regarding dinosaurs, Neanderthals, particle physics, etc. The other model, often labeled 'soft' concordism, assumes a greater overlap between what Bible and science addresses than in the 'soft' non-concordant model, but a lesser overlap than in the 'hard' concordist model. In this approach, most 
texts in the Bible are considered scientifically netural or irrelevant, and the scientific data is generally not assumed to have theological implications. This model is typically assumed by old-earth creationists, who, on the one hand, argue that Gen 1-11 is a factual, chronological description of the origin of the universe, and that texts such as Job 37-39, Ps 104, and Prov 8 contribute with important scientific information on Gen 1-11. On the other hand, it is also argued that there are scientific details which are not addressed by the Bible, and that scientific data on the origin of the universe should be integrated in a constructive interaction with the Biblical information. A characteristic of both concordant models is, furthermore, an emphasis on God's supernatural creativity as an explanation on the questions of origin, and that there are aspects in the origin of the universe which science is unable to explain because it lies outside the scope of science.

What needs to be added to or at least emphasized in the models outlined by Ross and Samples is, however, that no matter how comprehensive or minimal the overlap may be, it is an overlap between two different 'magisteria,' namely between scientific data (and their various interpretations) and Scripture (in its different understandings). In 1997 Stephen Jay Gold argued that science and religion are two 'nonoverlapping magisteria' (Gould 1997; cf. 2002). Gould drew the term 'magisterium' from Pope Pius XII's encyclical Humani generis (1950) and defined it as 'a domain where one form of teaching holds the appropriate tools for meaningful discourse and resolution' (Gould 2002,5). Whereas science, Gould argues, 'tries to document the factual character of the natural world, and to develop theories that coordinate and explain these facts,' religion 'operates in the equally important, but utterly different, realm of human purposes, meanings, and values' (Gould 2002,4). Contrary to Gould's concept of 'nonoverlapping magisteria' (NOMA), according to which the difference is between facts and values, Scripture in the 'soft' models does describe factual events and phenomena albeit in a different 'language' and with a different intent. Scripture's 'language' is not scientific in the modern sense of the word, and scriptural 'data' cannot be mined and analysed scientifically (in the modern sense of the word) through 'systematic observation and experimentation, inductive and deductive reasoning, and the formation and testing of hypotheses and theories'. It is a non-sequitur, however, that Scripture for that reason cannot contribute to our understanding of 'facts.' For two reasons.

First, Franscesca Rochberg has recently argued - in what many reviewers consider the potential successor and replacor of the influential The Intellectual Adventure of Ancient Man (Frankfort et al. 1946) - that it amounts to a 'lingering afterglow of scientism and positivism from the last century' to reserve the terms 'science' and 'rationality' for post-Babylonian, Western culture (Rochberg 2016, 140; cf. Mieroop 2017). Rochberg describes how the ancient Mesopotamians used analogical thinking, i.e. correspondences between otherwise unrelated phenomena, to interpret their world, and argues that, though

[t]he roles of analogy and analogical thinking have been slow to gain recognition as important parts of science ... analogy plays an important part in both the literary and the scientific imagination, as it did in the scholarly imagination of the 
scribes. Assyrian and Babylonian divinatory, astrological, magical, and medical texts that characteristically deal in correspondences and properties testify to one important context for the use of analogy in cuneiform scholarship (Rochberg 2016, 156-157).

The ancient Mesopotamians were not, in other words, ignorant of their world, and though their observations of reality had a different purpose than that of modern science, they produced, nonetheless, knowledge of that reality:

[T] he investigation of what [David] Brown called 'observed reality,' that is to say, the phenomena of the ancient scribe's perception, experience, and imagination, was undertaken not so as to understand 'observed reality,' that is, nature as such, or what we might call the workings of a structured world, but to interpret the perceived, experienced, or imagined phenomena for the purpose of divination, that is, to know what things meant. In the process of pursuing this goal, much was known of the world, including how parts of it 'worked' (Rochberg 2016, 125).

Since the Hebrew Bible - in any dating of its texts - was produced in the same cognitive environment and for a like-minded audience, we should expect (some of) its 'language' to be not only phenomenological but also analogical. And though its 'observations of reality' also had a different purpose than that of modern science, we should assume that pursuing their goal, the scribes responsible for the Hebrew also acquired knowledge of the world. We should not expect, in other words, to find 'values' only, but also 'facts' about reality in Scripture. The nonoverlapping elements are not facts and values, but facts produced by different conceptions of science.

Second, since it is beyond the limits of modern science to account for transcendent causes, Scripture may - at least for the theistic (or deistic) scientist - testify to phenomena undetectable by scientific method. The term 'undetectable' is chosen deliberately over 'inexplicable' to avoid a 'God-of-the-gaps' concordism in which God becomes a stand-in for gaps in scientific knowledge. It is important to define very carefully, what is meant by 'gaps.' Dietrich Bonhoeffer, in a letter to Eberhard Bethge, 29 May 1944, argued
how wrong it is to use God as a stop-gap for the incompleteness of our knowledge. If in fact the fronti- ers of knowledge are being pushed further and further back (and that is bound to be the case), then God is being pushed back with them, and is therefore continually in re- treat. We are to find God in what we know, not in what we don't know' (Bonhoeffer 1997, 310-12; letter to Eberhard Bethge, 29 May 1944).

The present writer fully concurs with such a rejection of a stop-gap concordism, but only if it is clarified that the expressions 'what we know' and 'what we don't know' is understood as 'what we know or don't know from modern scientific analysis and interpretation of observable reality' and thus allows Scripture to complement knowledge resulting from modern scientific research on empirical data with knowledge based on the possibility that phenomena may have transcendent causes. For the theistic (and deistic) scientist factual phenomena, in other words, may be caused by other than materialistic and naturalistic causes. 


\section{Galilei's hermeneutical principles}

In the book Controversy of the Ages subtitled Why Christians Should Not Divide over the Age of the Earth Theodore J. Cabal and Peter J. Rasor II argue that the hermeneutical principles used Galilei in the Copernican controversy may be helpful in the current debate on how to read and science and Scripture together.

The authors are well aware of the differences between the Copernican controversy and the current challenge from evolutionary biology. In the Copernican controversy both parties shared the same theistic worldview. An often-mentioned example is

Robert Boyle (1627-1691), who thought of scientific research as worship with the scientist as priest and nature as temple. Johannes Kepler, too, considered himself a priest in the temple of nature. It is to be emphasized, therefore, that the scientists of the $1500 \mathrm{~s}$ and 1600s all had a Christian point of departure. They were devoted Christian believers and considered their science an investigation of nature, not a challenge to the creator. For the same reason they all tried to find concordance between God's two 'books,' Bible and nature. In Darwin's time (1809-1882) science was no longer practised based on a Biblical worldview, and Darwin's evolutionary discoveries only strengthened the empirical and positivistic worldview, which, from the beginning of the 1800 s, had made its way into science. Darwin, after the publication of The Origin of Species in 1859, described himself as an agnostic, and probably ended up as an atheist (Cabal and Rasor II 2017, 51-58).

Or as Jes Fabricius Møller has it in an article on reactions against Darwinism in
Denmark in the period 1860-1900: 'There can be no doubt that an openly proclaimed support to Darwinism often goes hand in hand with a denouncement of Christianity' (Møller 2000, 70; my translation). For the same reason Darwinism (or Neo-Darwinism as it is called today) is closely connected with a worldview in which the origin of life in all its forms is given purely naturalistic explanations, and in which there is no room for a transcendent God's supernatural creative acts. An application of the criteria used in the Copernican controversy requires, therefore, a distinction between the scientific data (the fossil record, astronomic observations, etc.) and possible interpretations of these data (e.g., an evolutionary understanding of the fossil sequence in the empirical verifiable geological record and a dating of the age of the universe on the basis of astronomic observations), so that explanations demanded by a methodologically atheistic, naturalistic worldview, are discarded in favor of interpretations of the data which are consistent with a Biblical worldview.

Another difference not mentioned by Cabal and Rasor between the Copernican controversy and the present discussion on creation and evolution is that the conflicts should be placed on different levels as far as the theological consequences are concerned. Whether the sun circled the earth or the earth the sun had little consequence on matters essential to the Christian faith, whereas the discussion on creation and evolution may have a serious impact on the core understanding of anthropology, harmatology and - consequently salvation.

Where the Copernican controversy is helpful, however (and Cabal and Rasor argues this convincingly), is in the 'theological conservatism principle' exempli- 
fied by Galilei's tackling of the conflict between his own heliocentric worldview and the contemporary consensus on Biblical cosmology. In two letters to the astronomer Antonio Castelli in 1613 and the Grand Duchess Christina in 1615, respectively, Galilei described a procedure involving two interpretive criteria and two interpretive steps. The two criteria were 1) Scripture, not interpretations of the Scripture, is inerrant, and 2) nature and Scripture cannot contradict each other. The two interpretive moves were 1) that traditional interpretation must take precedence over scientific theories on which there is no consensus, but that 2) scientific theories on which there is consensus should call for reinterpretation of the Bible. Two criteria that in many ways express the soft concordist approach described above. The crux of the matter is, however, how these criteria were practised, and this is where Cabal and Rasor's proposal is so useful. The criteria were applied in a three-stage process, described by Cabal and Rasor with the sentences 'The two can never wed,' 'The two can court,' and 'The two can wed on these terms,' and it is this process they recommend in the contemporary discussion on the questions on origin (Cabal and Rasor II 2017, 40-47).

\section{They Can Never Wed}

The interpreters of the Bible in the Copernican controversy practised a theological arm's length principle characterised by a skeptical approach to new scientific theories that were seemingly incompatible with Scripture. The immediate reaction was, therefore, that 'they could never wed.'

\section{The Two Can Court}

As the old worldview came under more and more pressure and the new heliocent- ric cosmology was deemed less and less problematic, interpreters began - with Cabal and Rasor's expression - to 'court' each other. In this phase, very few interpreters accepted the new worldview, but more and more interpreters began to take it under serious consideration. A characteristic for this 'consideration' was, according to Cabal and Rason, that it was made 'innocent' or 'safe' to discuss (Cabal and Rasor II 2017, 41-43) .

The Lutheran theologian Andreas Osiander, who wrote the anonymous introduction to Copernicus' De revolutionibus orbium coelestium from 1543, encouraged readers to regard Copernicus' ideas as mathematical speculation with a hypothetical status, and the consequence was that a space was created in which (not least Lutheran) scientists could develop various models to describe the universe. Models that, importantly, were deemed compatible with Scripture. The challenge in this phase was, therefore, whether these models should be based on scientific theories, on Scripture, or a combination of both. And it was Galilei himself who came up with an approach that solved his own conflict (albeit only after his death) and has turned out to be useful in similar controversies.

\section{The Two Can Wed on These Terms}

The 'courting' phase moved, as is well known, interpreters from all confessions to acknowledge heliocentrism as the correct interpretation of the scientific data, and, consequently, to regard the traditional worldview as a misinterpretation of Scripture. Science didn't correct Scripture, but a better or true interpretation of the scientific data corrected both the existing geocentric interpretation of Scripture and the geocentric interpretation of the scientific data. 
An important point for Cabal and Rasor is that all this, i.e., the three-phase process, did not happen overnight. It took generations of tough discussions and inquisitory battles before a new consensus emerged. It was only after the publication of Newton's Principia in 1687 144 years after the death of Copernicus that the controversy decreased.

Another point is that 'the devil is in the detail,' since Galilei violated his own principle that only scientific theories on which there is consensus should call for new interpretations of Scripture, since he argued for a reinterpretation of Scripture before the heliocentric worldview had gained consensus among scientists. Though mathematical models had questioned the Ptolemaic or geocentric worldview already in Galilei's time, it took a Johannes Kepler (1571-1630), Tycho Brahe (1546-1601), Isaac Newton (16431727), and many others before a consensus demanding reinterpretation of Scripture emerged.

\section{A Case Study: The First Human Couple}

One of the most challenging issues in bringing 'God's two books' together is the apparent conflict between Scripture's claim that all humans descend from a first human couple and the neo-Darwinian assertion that we are descended from an ape-like population of at least several thousand and that there never was a bottle-neck of two. In the following we shall try to apply the Galilean hermeneutic described above by looking at, first, the relevant texts from Scripture, and, secondly, at a new approach to the scientific data published recently by Joshua Swamidass.

\section{Scriptural Data}

As far as common descent is concerned, the question is how to understand the narrative on Adam and Eve in Gen 2-3, and how other texts in the Bible refer to that story. To answer the first question we need to determine, first, the text's genre. Is it an account of a historical event in which everything should be taken literally? Is the narrative a symbolic or archetypal story? Or all the above? The answer may not be as simple as we would expect (or like). Against an understanding of the text as literal history is that it makes use of themes or mythemes also found in, primarily Mesopotamian, primeval or protohistorical texts. This is true for creation of man from earth/clay, first creation as a fertile and harmonious place, rivers flowing from that place and watering the rest of the world, the tree of life, a snake depraving man of eternal life, and the barring of man from returning to paradise. Is the author using these motifs or mythemes to tell the inspired and true version of primeval history? A full discussion is outside the scope of this article, but the discussion is, nonetheless, necessary, since the appearance of so many parallels between the Mesopotamian and Biblical texts is suggestive (cf. Kofoed 2015; 2016a; 2016b [in Danish]).

It is not only in the comparative material outside the Biblical text but also in the text, however, where we find features suggesting that the Biblical text is not just literal history. The lexeme not used indisputably as a personal name until Gen 4:25 where it is stated euphemistically that 'Adam knew his wife.' In

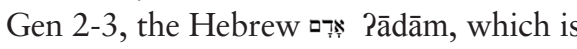
both a generic term for 'man' and the personal name 'Adam,' is used with a prefixed, definite article, and since Hebrew 
never fronts personal names with the definite article, it should be translated '(generic) man,' not 'Adam.' It could be argued, for the same reason, that the lexeme behind the translation 'Eve' is also not used as a personal name, since 'she' is referred to as 'helper' פēzer; Gen 2:18), and woman' (. Tišs Piššăh ${ }^{\mathrm{h}}$, Gen $2: 22$ ). And though the name חִ̣awwa $\bar{a}^{\mathrm{h}}$ given by 'man' to his 'woman' in Gen 3:20 may be transliterated (roughly) as Eve,' its meaning is 'life.' This is clear from the subsequent explanation 'because she was the mother of all living' in Gen 3:20, and illustrated by Gen 4:1, where 'man' impregnated this '[mother of] life' with Cain.

To this could be added that חִ̣ hawwa $\bar{a}^{\mathrm{h}}$ does not appear anywhere else in the Old Testament as a personal name. Does this mean that we should understand not only

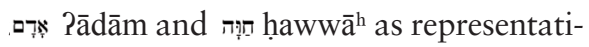
ves for 'man' and '[mother of] life' but also Cain and Abel as representatives of shepherds and farmers (Gen 4:2)? That is, in the same way as Jabal in the following pericope is representative of 'those who dwell in tents and have livestock' Gen $4: 20)$, Jubal of 'those who play the lyre and pipe' (Gen 4:21), and Tubal-Cain who 'was the forger of all instruments of bronze and iron' (Gen 4:22)? If so, it would allow for the development from the hunter-gatherer culture at the end of the Paleolithic era (100.000 - 12.000 B.C.) via the agriculture in Mesolithic period (12.000 - 7.500 B.C.) to the beginning urbanization and domestication of animals in the Neolithic period (7.500 - 4.000 B.C.) which, according to the consensus, took thousands of years, not as a non-representative reading of Genesis 4 implies - a few generations.

The features discussed suggest that the author may not have used the language to refer literalistically ${ }^{9}$ to historical processes, events and persons, and that we, con-

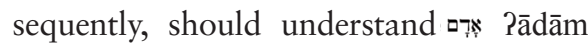
and חִָּ̣ hawwa $\bar{a}^{\mathrm{h}}$ representatively. An understanding of the text's genre which may be supported by parallels in the Mesopotamian sources, where the names of individuals between creation and the flood often are representative of the people or cultures they founded and/or represent (cf. Lowery 2013).

There is, however, also an 'on the other hand.' Though there are good arguments for the assertion that the personal names 'Adam' and 'Eve' does not appear until Gen 4:25, it could be argued that the absence of the prefixed definite article in םדָ ?ādām in the clauses '[a]nd to Adam

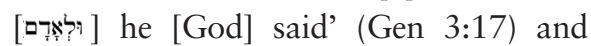
'[a]nd the Lord God made for Adam and for his wife garments of skins' (Gen 3:21) point in the opposite direction. Especially because we would have expected the use

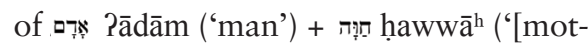

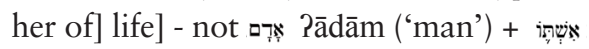
Pištô ('his wife') if a representative meaning was intended. Though the editors of Biblia Hebraica Stuttgartensia remark that the missing definite article in both Gen 3:17 and 3:21 must be an error on behalf of the Scribe and that we ought to add the particle in our reading, it is with no basis in the manuscripts. It would, furthermore, be awkward if verse 21 should be translated ' $[a]$ nd the Lord God made for the human/man and for his wife garments of skins,' since generic 'man' already at this point consisted in man and woman. Furthermore, when, in Gen 4:1, it is stated that 'man' or 'Adam' (depending on whether we understand it generically or personally) 'knew his wife,' the Hebrew חִ̣ hawwa $\bar{a}^{\mathrm{h}}$ is prefixed with the direct object marker $\mathrm{s}$, indicating that it is a particular חִ hawwa $\bar{a}^{\mathrm{h}}$ - presumably 
'Eve.' And whereas Gen 4:1 has דָָָ ?ādām prefixed with the definite article in the meaning (generic) 'man,' Gen 4:25 has พָָ Pādām without the definite article in the meaning (the person) Adam.' Besides, Adam,' in 4:25 clearly refer to the same בדָ ?ādām mentioned in 4:1, and there are good arguments, therefore, for

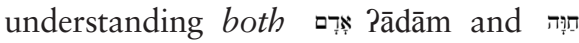
hawwa $\bar{a}^{\mathrm{h}}$ in 4:1 as personal names. And since they are likely to be personal names in the narrative on Cain and Abel, would it not also be natural to understand them as such in the preceding narrative? Such an understanding is also supported by the fact that Gen 2:4:4-26, according to the toledot-structure with a new toledot beginning only in 5:1, seems to consist of connected narratives. Finally, it could also be argued that, since all the other names in the genealogies of Gen 5 and 1 Chron 1 is understood as personal names, אדָד ?ādām should be taken as the individual progenitor of the following descendants.

As far as the Old Testament is concerned, the possible mentioning of the personal name Adam in Hos 6:7, where it is stated that 'like Adam they transgressed the covenant' with 'they' referring to Ephraim and Judah in verse 4. That it is only a 'possible' mentioning has to do with the fact that 'Adam,' according to Jos 3:16 also is a city, and that the breaking of the covenant mentioned in Hos 6:7 could have taken place in the city Adam not in the person Adam. The context of Hos 6 is of little help in deciding which meaning was intended. On the one hand, 'Adam' is mentioned together with other placenames such as Gilead in verse 7 and Shechem in verse 9. On the other hand, the following verses refer to other persons or groups of individuals, namely evildoers (v.8), priests (v.8), and House of Israel, Ephraim and Judah (vv.10-11).
The strongest indicator of its intended meaning is perhaps that the preposition : 'like' - as in 'like [the person] Adam' and not the preposition 7 'in' - as in 'in [the city] Adam' - is used. And though the editors of Biblia Hebraica Stuttgartensia suggest that the text should be emended to ביָאד] 'in Adam' - presumably because the preceding verses mention placenames - the text should be preserved, since there is no basis in the manuscripts for such an emendation. Even if we allow for an understanding of Adam as a personal name in Hos 6:7, it could both be understood as a reference to Adam as a representative or a personal name, so the attestation in Hosea cannot be used to determine which meaning of aד̦ ?ādām was intended in the contested verses in Gen 3.

In the New Testament, 'Adam' is attested in Luk 3:38, Rom 5:14, 1 Cor 15:22;45, 1 Tim 2:13-14 and Jud 14. In Luk 3:38, 'Adam' appears in Jesus' genealogy through Joseph's line, and since this use of 'Adam' is taken from genealogies presumably those of Gen 5 and 1 Chr 1 , it adds nothing new to the Old Testament attestations already discussed. The same is true for Jud 14, where Jude, with a quote from the pseudepigraphal 1 Enoch $1: 9$, states on his ungodly contemporaries that '[i]t was also about these that Enoch, the seventh from Adam, prophesied.'

The remaining New Testament attestations are different, however, in that they do have a bearing on the understanding of 'Adam' in Gen 2-4. In Rom 5:14 Paul writes that 'death reigned from Adam to Moses, even over those whose sinning was not like the transgression of Adam, who was a type of the one who was to come.' Paul makes the theological point from the comparison that 'if many died through one man's trespass, much more 
have the grace of God and the free gift by the grace of that one man Jesus Christ abounded for many,' (v.15), and 'as one trespass led to condemnation for all men, so one act of righteousness leads to justification and life for all men. For as by the one man's disobedience the many were made sinners' (vv.18-19). In 1 Cor 15, the use of 'Adam' stands in parallel to the one just discussed, albeit with more focus on the 'life' mentioned in Rom 5:18: 'For as in Adam all die, so also in Christ shall all be made alive' (v.22). Furthermore, and with a quote from the Greek translation of Gen 2:7: 'Thus it is written, "The first man Adam became a living being"; the last Adam became a life-giving spirit' (v.45). The final New Testament attestation of Adam' is in 1 Tim 2:13-14, where Paul as an explanation for the subordination of woman to man writes that 'For Adam was formed first, then Eve; and Adam was not deceived, but the woman was deceived and became a transgressor.' Besides these mentionings of 'Adam,' it is also relevant to mention Acts 17:26, where Paul states that 'he [God] made from one man $[\dot{\varepsilon} \xi \dot{\varepsilon} v \dot{v} \varsigma]$ every nation of mankind.'

It is also of interest that one of the socalled deuterocanonical or apocryphal writings, the Wisdom of Solomon, in the 1st century A.D. describes Adam as the 'father of the world' in its statement on Lady Wisdom: 'She preserved the first formed father of the world, that was created alone, and brought him out of his fall, And gave him power to rule all things' (Wisd 10:1-2; KJV). We find the same understanding of Adam in an earlier apocryphal writing, namely the Book of Tobit (4th-5th century B.C.), in which it is stated of God that 'Thou madest Adam, and gavest him Eve his wife for an helper and stay: of them came mankind'
(Tob 8:6; KJV).

Together with the aforementioned three uses of Adam' in corpus paulinum, these attestations are no doubt the greatest challenge for readings that understand Adam' in Gen 2-3 exclusively as a representative let alone a symbolic character. Furthermore, since the post-canonical attestations demonstrate that Adam and Eve are understood consistently as the first human couple and that the fall was understood as a historical event, the burden of proof is on those, therefore, who assert that 1) Adam and Eve were not historical persons, that 2) Gen 3 should not be understood as a narrative on a historical fall.

Besides, the history of interpretation is uniform for a reason, since it is very difficult to comprehend how the New Testament texts can be understood differently than an affirmation of Adam and Eve as historical persons, of the fall as a historical event, and of mankind as descending from the first couple. It is noteworthy, for example, that neither $\mathrm{N}$. T. Wright nor Kenton Sparks disputes such an understanding but admit that Paul understood Adam and Eve as historical persons and the fall as a historical event. When they, nevertheless, state that the narratives in Gen 2-3 should be interpreted representativaly or as symbolic stories, it is because Paul, in their interpretation of the New Testament texts, shared his contemporaries' errant understanding of Gen 2-3 .

Despite the preponderance of arguments for an understanding of Adam and Eve as historical individuals, the textual arguments for a representative interpretation must, nonetheless, be entertained as a valid reading since there are features in the texts challenging an exclusively 'historical' understanding. This is true for the 
representative role Adam and Eve also play in Gen 2-3, and the fact that they appear neither in prose nor poetry in the rest of the Old Testament (with Hos 6:7 as a possible exception). In the New Testament, a representative role could be supported by the fact that Paul, in Romans and 1 Corinthians, does not mention the individual who, according to Gen 3, was the first to sin, namely Eve. Instead, it is Adam, who is singled out, probably as a representative for both of them. The challenge for the traditional interpretation is therefore that, if Adam should be understood as representative for (generic) man in Rom 5 and 1 Cor 15, why should he not also be understood representatively in Gen 2-3?

The purpose here is not to settle the case, but the discussion suggests a model that both acknowledges 1) the representative role played by Adam and Eve in Gen 2-3, 2) the unmistakable reference to Adam and Eve as the first human pair, and 3) the fall as an historical event. Models operating with Adam and Eve as purely symbolic or literary figures seem impossible to reconcile with Scripture, while it seems difficult to argue for models open to Adam and Eve not being the only humans around at the time referred to in Gen 2-3. The modifier 'difficult' is chosen deliberatly in the assessment of the latter, since it is worth discussing whether Adam' in Rom 5 and 1 Cor 15 can be understood as a reference to Adam and Eve as representatives of a group of people created through planned or directed evolution.

\section{The Scientific Data}

The general consensus in evolutionary biology is that the best explanation (to put it mildly) of the available scientific data is the hypothesis of common descent and speciation, which says that all orga- nisms now on earth trace back to a single progenitor, and that there never was a bottleneck of two individuals in the process of speciation that resulted in the evolution of hominins. Joshua Swamidass, Associate Professor of Laboratory and Genomic Medicine at Washington University in Saint Louis, accepting this consensus, has recently suggested that the exclusive focus on genetic ancestry has created a discussion on false opposites that allows true discourse between intepreters of 'God's two books' to be suppressed .

The problem is, according to Swamidass, that whereas evolutionary biology discusses the reproductive origin of humans by tracing the origin of stretches of DNA, i.e., in terms of genetic descent, Scripture bases its arguments on genealogical descent, i.e., the reproductive origin of people (S. J. Swamidass 2018b, 6). Interpreting Scripture in terms of the modern, scientific category of genetic descent, creates, in other words, a false dichotomy between the consensus of evolutionary biology and interpretations by scholars with a high view on Scripture. ${ }^{10}$ If, instead, the two sets of data are interpreted according to their own categories, a different picture emerges. Using the emic categories of Scripture and contemporary science, respectively, to bring the 'two books' together, Swamidass suggests the following scenario:

Entirely consistent with the genetic and archeological evidence, it is possible Adam was created out of dust, and Eve out of his rib, less than 10,000 years ago, living in a divinely created garden where God might dwell with them, the first beings with opportunity to be in a relationship with Him. Perhaps their fall brought accountability for sin to all their natural descendants. Leaving the Garden, their offspring 
blended with their neighbors in the surrounding towns. In this way, they became genealogical ancestors of all those alive when recorded history begins about 6,000 years ago. Adam and Eve, here, are the sole-progenitors of all mankind. So, evolution presses in a very limited way on our understanding of Adam and Eve (S. J. Swamidass 2018b, 3).

The interbreeding necessary for the model may be alluded to in Gen 6:1 and Num 13:33, Swamidass mentions, and even if we identify Adam as early as 6,000 years ago, Swamidass continues, we may 'still estimate he would be ancestor of everyone alive by AD 1, before Paul writes Romans and the ministry of Jesus begins. The point is that all these accounts, including a literalist and traditional account of a de novo Adam, they fit without contradiction with evolutionary science' (S. J. Swamidass 2018b, 3-4). The explanation for this is given, helpful- ly for the scientifically challenged (including the present author), in a graphic illustration:

The illustration, Swamidass explains, show a cartooned pedigree, a genealogy, from past (top) to present (bottom). Squares and circles denote men and women, respectively, with lines indicating parentage. Red and blue individuals are those in the genetic lineages to a single ancestor, Mito-Eve and YAdam, respectively, with no relevance to Adam and Eve of Scripture. In contrast, every individual with a black border is a common genealogical ancestor of all those in recorded history (grey box). The Scriptural Adam and Eve (the black box and square) are created from the dust and a rib less than 10,000 years ago, have no parents, are in the Garden of Eden (black box), and are genealogical ancestors of everyone in history (S. J. Swamidass 2018b, 4).

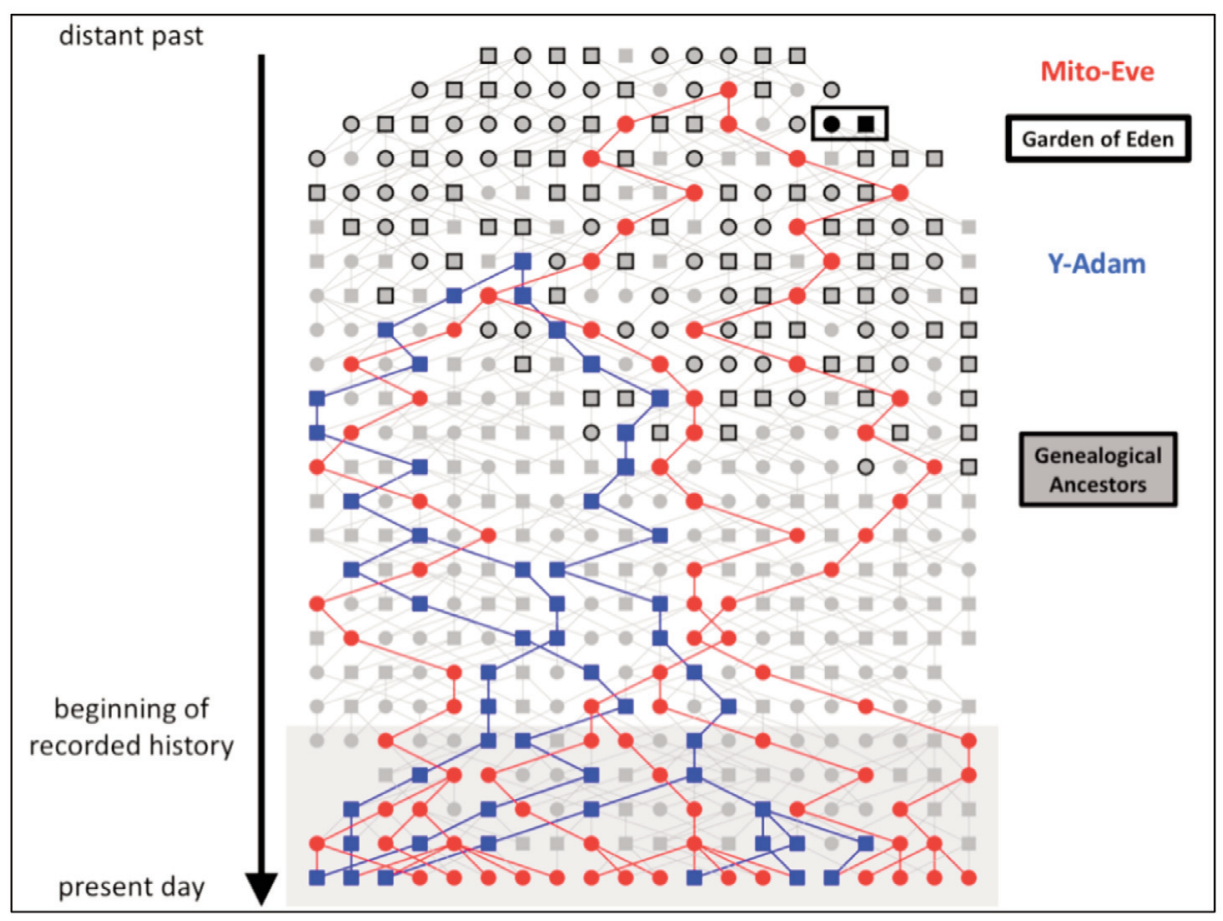

Theofilos vol. 12 nr. 12020 
Swamidass is not unaware of the challenges to the model posed by other aspects of the relevant texts from Scripture, not least the question of how, when and upon whom the image of God was bestowed. Was it also bestowed, for example, on the lines outside the garden with which the descendants of the couple in the garden interbred? If nevertheless, Swamidass asserts, 'important theological status transmits to us by genealogical descent, exclusively from Adam and Eve, then they would be our sole-genealogical progenitors, but not our sole genetic progenitors. Keep in mind that sole-progenitorship allows intermixing with other lines' (S. J. Swamidass 2018b, 3). In other words: True humanity, i.e., A $\delta \dot{\alpha} \mu$ Adam in the Pauline sense (Rom 5; 1 Cor 15), appears for the first time in the couple in the garden. All humans, therefore, descend

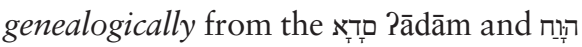
hawwa $\bar{a}^{\mathrm{h}}$ of Gen 2-4, whereas all humans genetically speaking, trace back to nonhuman progenitors, i.e., to hominins (and their hominid progenitors) outside the garden without the imago Dei.

When we make a firm distinction between 'genealogical ancestry' - which is the interest of the Biblical text - and 'genetic ancestry' - which is the focus of evolutionary biology - we guard against superimposing a 'genealogical' agenda on the interpretation of the scientific data. By suggesting that we grant legitimate autonomy to the Biblical text in its definition of the term 'human,' we similarly guard Biblical interpretations against 'genetic' eisegesis. And the scenario suggested by Swamidass in his synthesis of the genealogically focused Biblical texts and genetically oriented evolutionary biology might be 'an account,' in the words of Swamidass, 'where no conflict lies' (S. J. Swamidass 2018b, 4).
The point here is not whether the scenario suggested by Swamidass is - or is not - a convincing synthesis of mainstream evolutionary theory and Sciptural interpretations which adhere to a high view on Scripture, but the commendable approach Swamidass takes to the question so pressing for Galilei and so urgent today: In the apparent contradiction between interpretations of God's two books, is there a new path that can be walked that interprets the data of both with uncompromisable seriousness? Just as both the Catholic Church and individual Christian scholars from both Catholic and Protestant Churches eventually came to ask whether, in the light of the overwhelming scientific consensus on the heliocentric worldview, is was possible to interpret the Biblical text 'heliocentrically,' Swamidass invites us to ask, In the light of the overwhelming scientific consensus on the evolutionary origin of man, is it possible to interpret the Biblical texts and the scientific data in a complementary rather than contradictory way?

Swamidass' point of departure is, of course, that the scientific consensus now has become so overwhelming that interpreters of Scripture no longer can uphold the 'the-two-can-never-wed-approach,' and that time has come to seriously 'court' evolutionary theories. Given that is the case, and applying the principles of Galilei discussed above, the next questions are whether and, given a positive answer, on which conditions 'the two can wed.'

It goes without saying that the naturalistic or materialistic worldview under which mainstream evolutionary biology operates is utterly incompatible with a Scriptural worldview, and that the scientific data must be interpreted in accordance with the latter if serious 'courting' is to 
take place. But there are other conditions, that must be met as well. An 'uncompromisable' interpretation of the Biblical texts (i.e., an interpretation which adheres to a high view on Scripture) seems to be an understanding, as we have seen, of

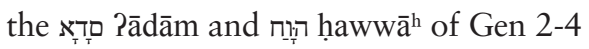
as both representatives of and sole genealogical pro-genitors of humankind.

Another 'uncompromisable' interpretation seems to be that the description of God's creative work is incompatible with the clockmaker-god of Deism, and that we need to allow for a more active role on God's part. Such a role is, however, largely undetectable by science, since scientific analysis is based on natural - not supernatural - causation. Whether or not God created the first humans de novo or through directed evolution, is a related (and difficult) question, of course, but the picture emerging from Gen 1-2 is not of a passive and uninvolved but very creative and intervening God. And though this intervention, again, may not be detectable for scientific inquiry, it needs to be taken into consideration in 'courting' evolutionary theories. Christian scholars must, in other words, insist that the principles of natural causation underlying mainstream evolutionary theories must be supplemented by supernatural ones. Not as a godof-the-gaps-argument, but as a necessary corollary to the worldview of Scripture. How, when, and to which degree supernatural causation took place is another matter on which Scripture is not clear and on which scholars adhering to a high view on Scripture, consequently, disagree.

Whether the scenario suggested by Swamidass honours these 'uncompromisable' interpretations of Scripture is a matter of debate, of course, but that's the whole idea! Keeping in mind that the Copernican controversy took generations if not centuries to solve and reminding ourselves of the dynamic and provisional character of scientific theories as well as the distinction between the authoritative norma normans and the derived norma normata, we should not expect the 'Darwinian controversy' to be solved over night. Just as it took a Kepler, Brahe, and Newton before it became obvious that the scientific consensus demanded a new interpretation of Scripture, it may take several 'post-Darwins' until (if at all) it becomes pressing or necessary to change the traditional readings of the creation accounts in Genesis.

\section{Discussion}

The purpose of recommending a debate on the compatibility or complementarity of evolutionary theories and interpretations of Scriptures along the lines of the Copernican controversy is not to foreshadow a similar result, namely that, just as Renaissance interpreters eventually caved in to heliocentrism, Christian interpreters will also come to accept readings compatible with some form of evolutionary theory. The process may, of course, lead to the result that 'the two can never wed.' Ted Cabal, for example, writes elsewhere that 'Darwinism has been courted and hybridized by even young-earth creationists (e.g. widespread speciation), but conservative evangelicals have remained opposed to an evolutionary first couple, believing it entails serious theological problems,' and that he is 'biblically unauthorized to accept' evolutionary creationism as described by representatives of BioLogos (Keathley, Stump, and Aguirre 2017, 66-67). Though for Cabal, the process has obviously (already?) convinced him that the courting will never result in a wedding, Cabal shares the view of Swamidass, that the time has come for 
Christian interpreters to 'court' theories of evolutionary science. And the negative outcome of Cabal's process should be understood - in the light of Cabal's own emphasis on the 'non-overnightness' character of the debate - as a contribution to that debate.

An important precondition for the debate is to create the same 'sandbox' for interpretative and hypothesizing experimentation as called for by the Lutheran theologian Andreas Osiander in the abovementioned foreword to Copernicus' De revolutionibus orbium coelestium, for various syntheses between interpretations of Scripture and scientific theories to be discussed without inquisitory strategies hindering a healthy and constructive debate. Initiatives taken by institutions and organisations like Discovery Institute, The Faraday Institute for Science and Religion, BioLogos and Reasons to Believe must be welcomed, therefore, since they have created precisely such sandboxes where models for interpretations of the scientific data can be developed and discussed. And the dialogue between representatives of BioLogos and Reasons to Believe with professors from Southern Baptist Seminary as facilitators - published in the already mentioned book Old-earth or Evolutionary Creation? - is examplary of the 'courting' necessary for clarifying whether traditional understandings of Scriptural texts on the questions of origin should be revised. The same is true for research projects like the Creation Project of the Carl F. H. Henry Institute for Theological Understanding at Trinity Evangelical Divinity School, with it's declared purpose to 'to catalyze a field of study around the doctrine of creation that is faithful to Scripture and informed by scientific evidence' (The Creation Project 2016). The same is true in principle for organisations like Creation Ministry International, Institute for Creation Research or Answers in Genesis, but - and there is a 'but'! - a characteristic of these organisations is that they usually demand a particular (and usually traditional) interpretation of Scripture as a precondition for 'courting' scientific theories. An obvious example is the addendum to the two Chicago Statements on Biblical Inerrancy /Hermeneutics (CSBI/H) suggested by the organisation Answers in Genesis, which sets as a condition for 'courting' scientific theories that interpreters agree on the following affirmation and denial:

We affirm that the great Flood described in Genesis 6-9 was an actual historic event, worldwide (global) in its extent and extremely catastrophic in its effect. As such, it produced most (but not all) of the geological record of thousands of meters of strata and fossils that we see on the earth's surface today.

We deny that Noah's Flood was limited to a localized region (e.g., the Mesopotamian valley of the Tigris and Euphrates Rivers). We also deny that the Flood was so peaceful that it left no abiding geological evidence. We further deny that the thousands of meters of sedimentary rock formations with their fossilized remains were largely produced after or before the Flood or even before Adam (Answers in Genesis n.d.).

These are interpretations, however, on which there is no consensus among interpreters with a high view on Scripture, that is, interpreters who adhere to the principles of the $\mathrm{CSBI} / \mathrm{H}$, and since the $\mathrm{CSBI} / \mathrm{H}$ is open to disagreement on these matters it could well be argued that the addendum suggested by Answers in Genesis runs counter to the spirit of the 
$\mathrm{CSBI} / \mathrm{H}$. This does not necessarily mean that 'creation science' of Answers in Genesis is unimportant or scientifically unsustainable, and interpreters of Scripture need to include this research in their process of 'courting.' The problem is, however, that the interpretative exclusivity of these organisations makes it impossible for dissidents to play in the same sandbox, and that the scientific theories of these organisations tend to become isolated and marginalized in relation to the broader scientific discourse necessary for clarifying whether they are better explanations of the scientific data than other models.

In addition to the need for such sandboxes for scholarly discussion, we need similar arenas for lay interaction in the church. This is somewhat more challenging, of course, since, unlike organisations which usually promotes one particular model or view, many churches want to create an environment that is inclusive of more than one interpretation. If the rhetoric is based on the empirical data and shows respect for proponents of differing interpretations of these data, and if a 'Galilean' strategy is followed, it should be possible, however, to create an atmosphere in which a high view on Scripture can be combined with sound conservative skepticism towards and critical testing of new scientific theories without creating the expectation that crises between God's two books on this level are likely to be solved in one's own generation.

\section{Works Consulted}

Andersen, Hanne, and Brian Hepburn. 2015. 'Scientific Method'. The Stanford

Encyclopedia of Philosophy. 2015.

https://plato.stanford.edu/archives/sum2016/entries/scientific-method/.

Answers in Genesis. n.d. 'Affirmations and Denials Essential to a Consistent Christian

(Biblical) Worldview’. Answers in Genesis. Accessed 25 August 2017.

https://answersingenesis.org/answers/affirmations-denials-christian-worldview.

Barbour, Ian G. 1990. Religion in An Age of Science. The Gifford Lectures 1989-1991 1.

London: SCM Press.

Biologos. n.d. Adam and Eve with N.T. Wright. Accessed 20 July 2017.

http://biologos.org/resources/audio-visual/nt-wright-on-adam-and-eve.

Bonhoeffer, Dietrich. 1997. Letters and Papers from Prison. Edited by Eberhard Bethge.

Translated by Reginald H. Fuller. New York: Touchstone.

Cabal, Theodore, and Peter J. Rasor II. 2017. Controversy of the Ages: Why Christians

Should Not Divide Over the Age of the Earth. Wooster: Weaver Book Company.

Frankfort, H., H. A. Groenewegen-Frankfort, John A. Wilson, Thorkild Jacobsen, and

William A. Irvin. 1946. The Intellectual Adventure of Ancient Man: An Essay on

Speculative Thought in the Ancient Near East. Pelican Books A198. Chicago: University

of Chicago Press.

Galilei, Galileo. 1968. The Assayer. Edited by A. Favaro. Opere 6. Firenze: Giunti-Barbera.

Giberson, Karl. 2018. 'The Relationship Between Science and Religion'. BioLogos.

19 November 2018. /blogs/archive/the-relationship-between-science-and-religion.

Gould, Stephen J. 1997. 'Nonoverlapping Magisteria'. Natural History 106: 16-22; 60-62.

- 2002. Rocks of Ages: Science and Religion in the Fullness of Life. New York:

Ballantine Books. 
Keathley, Kenneth, J. B. Stump, and Joe Aguirre, eds. 2017. Old Earth or Evolutionary Creation?: Discussing Origins with Reasons to Believe and BioLogos.

Downers Grove: IVP Academic.

Kofoed, Jens Bruun. 2015. 'Bibelsyn og bibelens genrer'. Dansk Tidsskrift for Teologi og Kirke 42 (2): 131-42.

—. 2016a. 'Fortæller, Hvad Vil Du? Om Struktur Og Genre i Genesis 1-11'. Dansk Tidsskrift for Teologi Og Kirke 1: 29-54.

- 2016b. 'Mytebegrebet Som et Nødvendigt Onde'. Dansk Tidsskrift for Teologi Og Kirke 1: 5-27.

Lowery, Daniel DeWitt. 2013. Toward a Poetics of Genesis 1-11 Reading Genesis 4:17-22 in Its Ancient Near Eastern Background. Winona Lake: Eisenbrauns.

Luther, Martin. 1963. Luther's Works. Lectures on Galatians Chapters 1-4. Edited and translated by Jaroslav Pelikan. Luther's Works 26. Saint Louis, MO: Concordia Publishing House.

Mieroop, Marc van der. 2017. Philosophy before the Greeks: The Pursuit of Truth in Ancient Babylonia. Reprint edition. Princeton and Oxford: Princeton University Press.

Møller, Jes Fabricius. 2000. 'Teologiske Reaktioner På Darwinismen i Danmark 1860-1900'. Historisk Tidsskrift 100 (1): 69-92.

Rochberg, Francesca. 2016. Before Nature: Cuneiform Knowledge and the History of Science. Chicago: University of Chicago Press.

Ruse, Michael. 2018. 'Creationism'. In The Stanford Encyclopedia of Philosophy, edited by Edward N. Zalta, Winter 2018. Metaphysics Research Lab, Stanford University. https://plato.stanford.edu/archives/win2018/entries/creationism/.

Sparks, Kenton L. 2008. God's Word in Human Words: An Evangelical Appropriation of Critical Biblical Scholarship. Grand Rapids, Mich: Baker Academic.

- n.d. 'After Inerrancy: Evangelicals and the Bible in a Postmodern Age'. The BioLogos Foundation (blog). Accessed 24 August 2017. https://biologos.org/uploads/static-content/sparks_scholarly_essay.pdf.

Swamidass, S. Joshua. 2018a. 'The Overlooked Science of Genealogical Ancestry'. Perspectives on Science and Christian Faith 70: 19-35.

- 2018b. 'The Genealogical Adam and Eve'. Paper read at the Dabar Conference on Reclaiming Theological Anthropology in an Age of Science, Carl F. Henry Center for Theological Understanding, Trinity Evangelical Divinity School, June 14.

- 2019. The Genealogical Adam and Eve: The Surprising Science of Universal Ancestry. Downers Grove, Illinois: IVP Academic.

Tanzella-Niti, Giuseppe. 2004. 'The Two Books Prior to the Scientific Revolution'. Annales Theologici 18: 51-83.

The Creation Project. 2016. 'The Creation Project'. Henry Center for Theological Understanding. 4 October 2016. http://henrycenter.tiu.edu/evangelical-theology-and-the-doctrine-of-creation.

Wikipedia. 2018. 'Biblical Literalism'. In Wikipedia. https://en.wikipedia.org/w/index.php?title=Biblical_literalism\&oldid=865924104. 


\section{Notes}

${ }^{1}$ I thank Lars Dahle, Bjørn Hinderåker, and Peter Williams for organizing the Veritas Research Symposium in which an earlier version of this paper was presented. I am grateful for the comments and criticisms provided by the other speakers at the symposium and at the research seminar of Fjellhaug International University College, Denmark.

2 Reported by Socrates Scholasticus, Historia Ecclesiastica, IV, 23 (PG 67, 518).

3 Sermones, 68, 6 (PLS 2, 505).

4 Confessiones, XIII, 15, 16

5 The distinction between general and natural revelation was not Luther's invention, of course, since it was introduced already by Thomas Aquinas (c.1225-74), who defined 'natural theology' as the task of discovering what we can know about God and his truth wholly apart from special revelation.

${ }^{6}$ I thank my colleague Peter Olsen for these references.

7 Pivotal was of course texts on the mobility of the sun (Josh 10:12-13//Hab 3:11; Ps 19:4-6; Ecc 1:5), and the stability of the earth (1 Sam 2:8; 2 Sam 22:16; Isa 24:18; Job 9:6; 38:4-6; Ps 18:15; 93:1; 96:10; 102:25; 104:5; Prov 8:27-29; 48:13; 1 Chron 16:30; Joh 17:24).

8 A different approach may be found in the suggestion by the late Ian Barbour who, in 1988 (and in an elaborated version in his 1990 Gifford lectures) suggested that the relationship between science and religion be understood in terms of the four models of conflict, independence, dialogue, and integration (Barbour 1990; for a brief outline of the models see Giberson 2018).

9 Wikipedia's distinction between and definition of literalistic and literal readings is representative of how it is used by the present writer: 'Biblical literalism or biblicism is a term used differently by different authors concerning biblical interpretation. It can equate to the dictionary definition of literalism: "adherence to the exact letter or the literal sense," where literal means "in accordance with, involving, or being the primary or strict meaning of the word or words; not figurative or metaphorical"' (Wikipedia 2018).

10 One representative expression of such a 'high view' would be the two statements issued by International Council of Biblical Inerrancy (ICBI), namely Chicago Statement on Biblical Inerrancy (CSBI) and Chicago Statement on Biblical Hermeneutics from 1978 and 1982. ICBI was officially dissolved in september 1987, and all historical documents were transferred to Dallas Theological Seminary's archive, from where they may still be accessed (http://library.dts.edu/Pages/TL/Special/main.shtml). 


\title{
Theofilos
}

A Nordic open access journal in Theology, Philosophy and Culture

Published by NLA University College - in partnership with Johannelund School of Theology

Available at www.theofilos.no

\section{How did sin enter the world? In dialogue with natural science}

\author{
Gunnar Innerdal \\ Associate Professor of Systematic Theology \\ NLA University College, Bergen, Norway
}

\begin{abstract}
This article suggests an answer to how sin entered the world if current natural science makes it unlikely that it happened in the way told in traditional narratives of Adam and Eve. After reviewing some current alternatives, I argue that the best available way is to understand sin as a contingent historical reality arising through a process connected to the evolutionary rise of human beings.
\end{abstract}

Keywords: Human origins, sin, the fall, historical Adam, science, hermeneutics

$\mathrm{F}$ or a systematic theology attentive to natural science, ${ }^{1}$ questions concerning the reality, origin and impact of sin are among the most complex and challenging today. ${ }^{2}$ The aim of this article is to discuss some of those questions, centering on the origin of humanity and sin, questions where Christian doctrine grounded in traditional narratives of the origin of the world, humanity and sin, are challenged by recent scientific findings. My intention is not to provide an apologetic for any specific given historical or contemporary version of Christian doctrine, but to contribute to the constructive systematic theological task of putting forth Christian faith as a coherent way to understand all of reality and human living. ${ }^{3}$ The research question can be phrased in this way: If sin is not a (metaphysical) necessity, but a historical and contingent phenomenon, and traditional narratives on sin and human origins are no longer plausible on scientific grounds; how then did sin enter the world?
I will start by discussing the plausibility problems connected to what I call traditional narratives about how sin entered the world. Then I will advance to a theological discussion where I give reasons for adherence to the first if-clause of the research question on sin as not necessary, but contingent. Lastly, after surveying some available positions on the matter, I suggest how one can imagine sin having entered the world as a contingent phenomenon within a scientifically informed Christian interpretation of reality today.

\section{The Plausibility Problems of Traditional Narratives}

For centuries, many (probably most) Christians believed in some kind of way that Adam and Eve were the concrete and historical two first human beings, a single couple from whom all later humans descend physically. 5 They were created by God in a blissful state of perfection 6 , without sin, in a world without death and evil. ' However, because of their 'fall' 8 into sin after being tempted within the created 
realm, death and decay entered the world as a consequence, and the human lineage consequently came under an inescapable bondage to $\sin .^{9}$

Versions of such traditional narratives come to expression in a range of Christian practices throughout history, such as in art, poetry, liturgy, and confessional or creedal statements, in implicit and explicit ways. Apart from the explicit historical claims such traditional narratives make, they are used in doctrinal contexts, among other things, as part of different kinds of theodicies, theories of salvation/ atonement and the freedom or bondage of the will in relation to salvation. Then again, it has significance in connection to the theology of original sin connected to (infant) baptism and the Virgin birth in many theological systems. ${ }^{10}$ They are therefore of great importance within a comprehensive theological framework.

Particularly after the Enlightenment and the rise of modern science, this kind of narrative has been heavily questioned within as well as outside the church, often for different scientific reasons. ${ }^{11}$ Charles Darwin's (1809-1882) theory of the origin of the diversity of species through natural selection from common ancestry, coupled with modern geological theories of an old universe and earth, has been and continues to be one of the central challenges raised to such a narrative. After Darwin, many other scientific insights and theories complete the picture. However, the theological and religious philosophical significance of the theory of evolution is far more nuanced and complex than a simple yes or no to Christian faith, or any other kind of faith, 12 or a yes or no to the authority or content of the Bible13.

Scientific evidence from evolutionary biology, paleontology, geology, and gene- tics question especially two notions in the traditional narrative sketched above. The first is the idea of so-called monogenesis that all human beings descend from one single couple only. Most population geneticists today hold that the human population never was below at least 10000 individuals during the transition from the evolutionary precursors to homo sapiens (anatomically modern human beings). The second is the idea of a paradisiac origin of humanity. There is no empirical evidence of human beings sometime living under conditions dramatically different from ours when it comes to the presence of suffering and futility in the world or some kind of moral perfection associated with a pre-lapsarian (pre-fallen) state.

It is important to emphasize the hypothetical nature of the reasoning in the discussion that follows. It might be that an intellectual discussion relating traditional theological narratives and current science is not necessary or relevant in many contexts and for many people. A mythical, metaphorical, or kerygmatic approach to the questions might do as good a job as a systematic treatment based on rationality, coherence and available science in many contexts. ${ }^{14}$ And further, because of the inherently hypothetical and not-yetcomplete nature of science, my suggestions should not be read as final, absolute answers to how the complete integration of theology and science must forever look from now on. They are instead to be taken as conditional propositions: if what science says on this or that point is true, and we think that science really is a pursuit of truth and can help us discern something of it, even from a theological perspective, then an answer to how to relate Christian faith to it might look like this. Performing such a task is a part of 
the Christian apologetic task of being able to give a rational account for our belief (cf. 1 Pet 3:15).

\section{Scripture Interpreted by and Interpreting Science}

Debates about Adam, evolution, and the origin of sin among Christians tend to run quickly into questions about biblical authority, hermeneutics and exegetical questions pertaining to texts in both biblical testaments. It is impossible to survey the whole range of questions, positions and arguments involved in such matters here, and I am consciously trying to avoid making the question purely an issue of biblical authority or exegetical topoi or a combination of these. My aim is rather to make a systematic theological discussion about patterns of thought in conscious interaction with the many layers of tradition, including biblical interpretation, which we are confronted with in such discussions.

Nevertheless, I will have to make some brief remarks about my Augustinian kind of thinking about the most important questions of the relationship of science and biblical interpretation that is implied in the reasoning that follows. I take these to be largely uncontroversial, although their later application might be controversial. When relating Scripture and science as part of a theological system, ${ }^{15}$ I do not think that biblical authority or specific interpretations of biblical texts is established before making a theological system on this basis, but that the theories of how to use Scripture and how it relates to scientific findings is an integral part of the theological system itself. ${ }^{16}$

In some oft-quoted passages from his treatise on The Literal Meaning of Genesis (De Genesi ad litteram) Augustine of Hippo (354-430) writes:
In matters that are obscure and far beyond our vision, even in such as we may find treated in Holy Scripture, different interpretations are sometimes possible without prejudice to the faith we have received. In such a case, we should not rush in headlong and so firmly take our stand on one side that, if further progress in the search of truth justly undermines this position, we too fall with it. That would be to battle not for the teaching of Holy Scripture but for our own, wishing its teaching to conform to ours, whereas we ought to wish ours to conform to that of Sacred Scripture. ${ }^{17}$

We can discern two basic hermeneutical principles for biblical interpretation here. The first is the awareness that there are instances where Scripture can be interpreted differently based on honest truth-seeking within other disciplines without obscuring the faith. The second is a certain caution about binding biblical interpretation too tightly to scientific evidence that is not clear enough to bear the burden, while still not refusing to try to think them together. A similar attitude is famously put in proverbial form by Holmes Rolston III: 'The religion that is married to science today will be a widow tomorrow. [...] But the religion that is divorced from science today will leave no offspring tomorrow.'18 Although any kind of relationship with contemporary science remains in some way an incomplete, hypothetical and preliminary project, there is no real alternative to trying to make such relationships.

Augustine writes further on potential conflicts between supposed interpretations of biblical texts and something like what today would be called scientific evidence: 
Usually, even a non-Christian knows something about the earth, the heavens, and the other elements of this world, about the motion and orbit of the stars and even their size and relative positions, about the predictable eclipses of the sun and moon, the cycles of the years and the seasons, about the kinds of animals [Darwinian sic!], shrubs, stones, and so forth, and this knowledge he holds to as being certain from reason and experience. Now, it is a disgraceful and dangerous thing for an infidel to hear a Christian, presumably giving the meaning of Holy Scripture, talking non-sense on these topics [...]. The shame is not so much that an ignorant individual is derided, but that people outside the household of the faith think our sacred writers held such opinions, and, to the great loss of those for whose salvation we toil, the writers of our Scripture are criticized and rejected as unlearned men. If they find a Christian mistaken in a field which they themselves know well and hear him maintaining his foolish opinions about our books, how are they going to believe those books in matters concerning the resurrection of the dead, the hope of eternal life, and the kingdom of heaven, when they think their pages are full of falsehoods on facts which they themselves have learnt from experience and the light of reason? 19

What Augustine puts well here is that where clear scientific evidence, based on real empirical evidence and sound theoretical reasoning built upon them, conflicts with an interpretation of Scripture we hold to, this tension has to be relieved. 20 In most cases, this would amount to some kind of re-thinking of our interpretation of Scripture - or, by extension, the traditional teaching of the church based on such an interpretation of Scripture, as in the case of the traditional narratives referred to above. This principle does not mean that Scripture cannot correct human knowledge; there are historical examples of ideas later being recognized as good science that had their roots in theological ideas, and it is thinkable that science may learn from theology even in questions related to the ones discussed here. But when interpretations of Scripture require scientific 'non-sense' on any given topic, our first inclination should be to re-think our interpretations rather than to insist on biblical authority or inerrancy, or to engage in hopeless alternative scientific projects. ${ }^{21}$

\section{State of the Science}

The crucial question to be raised after laying out these hermeneutical principles is: What are the established scientific facts concerning the matters discussed? There are many pitfalls available for simplistic answers here, and I cannot give anything close to a complete scientific answer for my own, due both to my fields of scholarly competence as well as the number of relevant scientific sources.

Traditionally, the dividing lines between theologians and Christians of different types regarding the historicity of Adam and humanity's fall into sin has mainly been drawn between 'conservative' Christians professing a strong version of the (in some sense literal) authority and reliability of Scripture, and 'liberals' that more freely could dismiss biblical texts as collections of outdated ideas. However, in recent years, in response to clearer scientific evidence, the discussion has moved also inside 'conservative' circles, within a spectrum including Evangelicalism as well as Catholicism, where the authority of Scripture is taken more for granted. ${ }^{22}$

The Christian biologist Dennis R. 
Venema summarizes the scientific debate regarding some questions important to the discussion in this article in the following rhetorically heightened way:

many theories in science are so well established that it is highly unlikely new evidence will substantially modify them. [...] The sun is at the center of our solar system, humans evolved, and we evolved as a population. 23

Venema's claim of heliocentric certainty on this point has been subject to some debate. After a long discussion taken up by biologist Richard Buggs, Venema acknowledged that all of humankind may (mathematically) genetically stem from two sole individuals living about 700000 years ago. ${ }^{24}$ This scenario will need to involve a sudden catastrophic dip of the population of all Eurasian hominins living at the time ${ }^{25}$ to the number of two in a single generation, followed by a rapid exponential growth, and this is highly implausible, in Venema's words not even 'remotely plausible'. ${ }^{26}$ So his point stands.

Thus, in the words of Ian McFarland, '[b]y Augustine's own hermeneutical criteria' the traditional narratives mentioned above cannot stand, even if Augustine adhered to a version of them himself. ${ }^{27}$ There never was a single first human couple defining the course of the rest of the history of humanity by their actions. If this is the case - and there are good reasons to think that - we are left with a series of hermeneutical-theological and apologetic tasks. Traditional Christian doctrines and their narrative backdrop as sketched above must be thought through anew, being sensible to what is essential to them and how to continue to interpret the biblical texts behind them as authoritative and life-giving Word of God in light of our best scientific knowledge. 28

\section{The Contingency of Sin}

A possible way of responding to the plausibility problems of traditional narratives and doctrines facing current science, would be to abandon them and the doctrines they support entirely. ${ }^{29}$ This solution may threaten to undermine the Christian faith as such. The path taken here is another one: first to explore (briefly) what the significant central elements of the doctrine of $\sin$ and the origin of $\sin$ are in a systematic theological perspective, then to try to express those in a way attentive to scientific insights. I will try to make this first step by way of a summary expanding on four theses, after some initial methodical considerations.

The Christian message is first and foremost a message about Christ and God's grace given in him. It is from the vantage point of the redemption of Christ that we as Christians look backward in direction of the beginning and forward in direction of the eschaton. ${ }^{30}$ More than an account of exactly what historically went wrong in the world, where, when and in which way, the doctrine of $\sin$ is a doctrine about our current shared need of the salvation that God graciously gives in Christ's death and resurrection. The doctrine of $\sin$ is rather a consequence, the flipside of, the doctrine of redemption than a presupposition for the doctrine of redemption in Christ. ${ }^{31}$

My first thesis on central elements of the doctrine of $\sin$, is that $\sin$ is a reality. This is a very basic insight in Christian theology: we have a problem. That $\sin$ is a reality means either that sin has always been a reality, or that at some point this reality has come into existence. The almost universally shared human experience that it is something wrong in the world and human life, that things are not 
either the way they were, or should have been or shall become, suggest that the current state of the world is not simply the way things have always been and will always be. ${ }^{32}$ Sin is experienced almost universally by human beings through such phenomena as evil, deceit, violence, abuse, greed and so on, but also through anxiety or Anfechtung arising from our damaged relation to God. However, sin is not as such detectable scientifically as a problem, at least in its moral aspects. The natural scientist as scientist can say much about how things are and what people (or animals) do, but not about what they ought to do. To identify $\sin$ as $\sin$ and make human beings responsible for their lives and accountable toward God the Creator, it is necessary to activate philosophical and/or theological reasoning.

Second, all human beings are sinners and thus in total need of God's salvific interception. According to Lutheran theology (and most other Christian traditions), sin is a problem we are not able to solve ourselves on our own, either individually or corporately. However, it is probably more correct to say that we are all sinners because we all sin/are sinners, than because our fore-parent(s) did. ${ }^{33}$ The inevitability of sin in each human being's life is thus not due to a forcing necessity that can free us from responsibility or guilt, but to a kind of accumulative pressure of living as part of a collective humanity continually sinning and in a world marked by that. There is one exception to this rule, though. The basic insight in Christology that Jesus Christ was fully divine and fully man, yet without sin (cf. Hebr 4:15), shows that it is not an essential feature of humanity to be sinful even if every human being except Christ are sinners - and this holds even regardless of whether there were ever a concrete pre-historical paradisiac sinlessness of human beings.

Third, sin is our fault, not God's. This is a kind paradox given the belief in God as creator of everything, thus rejecting forthright metaphysical dualism. Is it expressed as such e.g. in the Augsburg Confession art. XIX 'although God does create and preserve nature, yet the cause of sin is the will of the wicked' (emphasis mine). God created everything but is not the cause of sin! Dietrich Bonhoeffer puts this point strikingly:

The Bible does not seek to impart information about the origin of evil but to witness to its character as guilt and as the unending burden that humankind bears. [..] It will [..] never be possible simply to blame the devil who has led one astray; instead this same devil will always be precisely in the place where I, as God's creature, in God's world, ought to have been living and did not wish to live. [..] [It is] just as impossible to accuse creation of being imperfect and to blame it for my evil. The guilt is mine alone. 34

Fourth, a fundamental Christian insight regarding $\sin$ (and its associates suffering, death and decay) is that it does or did not have to be this way. In every concrete act of sinning as well as in all humankind having become sinners in the stronger sense, in our current lives as well as in the lives of our forebearers, it is possible to imagine not sinning. This implies that God is not/was not forced to use the cruelties of the evolutionary process as his only option for creating something good (in this sense our sinful world is not the best possible world, but perhaps the best possible world with us in it ${ }^{35}$ ). As a Christian endorsing the strict scientific theory of evolution and its empirical basis, I still 
think it is important that we do not conflate the concrete evolutionary process and the concrete sinful human history in this world with God's original will or his only option for creation. ${ }^{36}$ Instead of viewing evolution as God's ultimate intention, one should view evolution as God's way of sustaining and by novelty make all of creation flourishing under present conditions, including human sin. It is possible to imagine an evolutionary process with both more or less of the dark sides of suffering, evil and death, but that would be another world.

\section{How Sin Entered the World}

If $\sin$ is to be conceived as a reality that is not necessary and cannot be blamed on God, it seems that in some sense sin must have 'entered' the world at some point or in some way. The expression comes from Paul in Rom 5:12, using the word eiserkhomai, to come into. ${ }^{37}$ The phrase has a similar kind of paradoxicality to it as the snake in the Garden story (where did it come from?), for was sin in any sense or anywhere before it entered the world, which seems to follow from the spatial expression in the metaphor? Perhaps a better term would be to say that sin arose within the world, but for the sake of familiarity I will stick to the traditional term. Biblical theology as well as anthropological and philosophical considerations strongly suggest that this entrance of $\sin$ is in some way closely connected to the rise of humankind.

I will start my suggestive discussion about how this can be imagined in a scientifically informed Christian faith today by sketching out four types of alternatives currently trying to respond to the plausibility problems of the traditional narratives outlined above while being attentive to current natural scientific knowledge. ${ }^{38}$
They are all closely connected to the question of the historicity of the first sinners in traditional narratives, Adam and Eve, and their scientific plausibility.

\section{Current Alternatives to Traditional Narratives}

A first type of views is those that champion more or less purely existential interpretations of the Genesis narrative. The story of the disobedience of Adam and Eve is primarily exemplary or typological, expressing common elements of the human condition. This type of views does often not in a strong sense answer the question in the way I have framed it here, but elements of such views can be interesting alternatives for integration in a nuanced position, because they often contain insightful perspectives on the current situation of human beings as sinners.

According to these types of views, Adam and Eve are not historical individuals, and the 'fall' into sin is not an event in history with a before and after in the normal sense, but some kind of mythological or figurative narration of the common human condition. An oft-quoted representative of this view is Søren Kierkegaard, who emphasized that the condition present at Adam's fall into sin is not radically different from the condition when we all make that same fall. ${ }^{39}$ Dietrich Bonhoeffer also comes close to such a position because of his insistence on the inaccessibility of our origins and the fall. 40

A weakness of these types of views is that they might easily be taken to imply that $\sin$ is just the way things are and always have been (thus perhaps compromising creation's original goodness and the contingency of sin), since proponents often refuse to take a stand on the question of how sin entered the world. ${ }^{41}$ 
A second type, and a more full-fledged attempt to answer my framing of the question, is views where an attempt is made to uphold the idea of only two concrete individuals as the genetic origin of our species. ${ }^{42}$ But to avoid inconsistency with genetics, this couple is placed way back in history compared to traditional readings of the historical context of Genesis, which are based on e.g. traditional biblical chronologies or the presence of agriculture in the story. This type of view is, as noted above, scientifically possible, but highly implausible. ${ }^{43}$ The Garden (in some kind of figurative sense) story of Adam and Eve, according to this type, stands for the first two human beings, which must be taken in a loose, homininlike sense, sometimes including Neanderthals and Denisovians and other of our human-like relatives, falling into sin in a very distant past. Such versions can be found in circles affinitive to or affirming Intelligent Design-thinking. ${ }^{44}$

This type of solution raises as many questions as it solves regarding human uniqueness and sinfulness. Besides being scientifically implausible, bordering on impossible, this kind of solution is also highly arbitrary in exegetical and hermeneutical perspectives. It is difficult to see, for example, why the notion of a historical ancestor couple is the only point in the story recorded in Genesis that should be taken literally, while its historical and geographical context, as well as what the text says about the origin of other animals or the presence of agriculture, should not. This kind of views can be excluded from further discussion here as a possible but currently not even remotely plausible alternative.

A third type of views affirms some kind of fairly recent ${ }^{45}$ historicity present in the Genesis narrative about Adam and
Eve. 46 This can happen in a way taking them to be two concrete historical persons, or by making them representatives of the human race, either as individuals or a group.

A first subcategory affirms that the Adam and Eve of Genesis were two concrete historical individuals in the recent past who are parents (in genealogical sense) of all human beings made in the image of God. However, to be reconcilable to genetic science, this couple is not conceived as the sole genetic progenitors of all humankind. This is a deviation from what I have called traditional narratives since it does not uphold monogenism. This couple's universal parenthood of modern humans came through gradual mingling with other creatures existing at the time. The transition from pre-human ancestors to humans made in the image of God happened through a special intervention by God, either through a special spiritual endowment of already existing creatures, or a new miraculous creation of two individuals with similar genetic attributes as fellow human-like creatures. The Garden story recounts a rebellion against God that happened with the first human beings in this sense, which later spread to all humankind.

A classical proponent of such a view is theologian John Stott, using the term homo divinus ('divine' man) for the first human beings created in the image of God, then falling into sin. ${ }^{47}$ The Christian scientist S. Joshua Swamidass has recently strongly championed the scientific possibility of this kind of view, emphasizing that it is genetically possible that all current human beings, as well as all human beings alive at $\mathrm{AD} 1$, share a sole couple living recently in the Middle East as genealogical (not genetic) ancestors. ${ }^{48}$ If so, those were not our only (or first) ${ }^{49}$ 
genetic ancestors, and interbred with other biologically similar creatures at the time, which Swamidass calls 'people outside the Garden'50, who had evolved through common descent (cf. the old question about Cain's wife, Gen 4:17). Through the generations, all living human beings through this original couple's lineage might have had a share both in their creation in the image of God and their fall into sin and its consequences. C. John ('Jack') Collins comes close to this view from another angle (without stressing the insights from genetic/genealogical science), saying that Adam and Eve where representatives of the initial human population, their 'father/king and mother/queen', and stressing their universal parenthood for later humanity. 51

In another subcategory of type three we find theologians insisting on the historicity or event-character of the fall all the while avoiding the claim that Adam and Eve were two concrete historical human persons. Instead, it is said that the Genesis story refers to real historical events, but narrated in a figurative, not literal sense, as is also the case with Collins. Thus, Adam and Eve can be taken to stand for an initial group of human beings representing them all vis-à-vis God. Some authors, especially in the reformed tradition, apply the concept of covenant to this kind of representation idea, borrowing from OT biblical theology and a certain reading of Hos 6:7.52 A recent example of this is James K. A. Smith, who argues that there might have been an initial group of hominins 'elected' by God into a covenant, but his solution borders on type four because he places the event further back in time. ${ }^{53}$

A fourth type of views claims that sin entered the world through a gradual process connected to the rise of humankind as a population or certain characteristics of humanity, such as consciousness or ability for moral reflection or a special relation to God, and not through individuals (or groups) acting in a singular event. There have probably been suffering and death and natural behavior close to evil in the proper sense involved in natural processes long before human beings stepped on the earth, but sin in the proper sense committed by someone accountable for it arose when human beings became evolutionary capable of sinning in that sense. The South-African theologian Ernst M. Conradie is a current champion of such a view articulated into some detail. 54

The most important strength of this kind of solution is that it requires little adjustment to standard scientific accounts of the history of humanity in order to integrate science and biblical concerns. It can also be argued that it is based on a more refined biblical hermeneutic, even if it raises important questions about how to understand apostolic authority and the literal sense of apostolic texts of the NT in some theological milieus. Its main weakness in relation to traditional narratives is that the event-character of the 'fall' is weakened.

\section{Discussion of the Most Promising Types}

Views of both the third and the fourth type might deserve a closer look as they are both scientifically and exegetically possible and to some extent plausible. Type three usually avoids scientific nonsense in the hermeneutical sense of Augustine, but remains very hypothetical at the scientific level; there is no evidence against it, but there is also no scientific data suggesting that this really was the case, while there is scientific data and 
plausible interpretations of them that at least implies that it was not the case. In order to make the idea come up scientifically at all, a certain historical-literally minded reading and hermeneutic of Scripture must be presupposed, 55 so the weight of support for this argument must lie on the theological side.

When it comes to biblical hermeneutics, type three has an easier task in integrating New Testament material about Adam in the framework of a theology strongly emphasizing apostolic authority. There are passages in which both Paul, Jesus and the author of the Gospel of Luke seems to talk of Adam in a sense close to what we today would probably call a historical human person. ${ }^{56}$ But in the exegesis of Genesis and other relevant OT texts things are more complex. Why, for example, must the claim that the first human being Adam was created 'from dust' and given 'breath of life' (Gen 2:7) indicate a kind of special creation or intervention concerning the creation of human beings in evolutionary perspective, while the same terms applied to other animals (Gen 1:20;2:19) are not taken at the same level? And how is it to be explained in this kind of scenario that the narrative places the creation of animals chronologically after the creation of the first human being? Emphasis on a literal creation of Adam and Eve also seems to be little consistent with far-spread nonliteral interpretation of other literal aspects of the text. Few Adam and Eve supporters insist e.g. on the historical character of the walking and talking snake (no fossil evidence of such a species at the supposed time), the geographical location of the Garden (the rivers and lands of 2:11-14; and the location of the tree of life and the flaming sword, or their continued existence, 3:24) and the impli- cit presence of Adam's mother and father in the narrative (2:24).

Type three can also have some difficulties in its theological implications. In this model, the historical transition into humans in the full sense must presuppose some kind of miracle or special divine intervention. While this is a possibility, it is not clear why that must follow from a reading of Genesis that is not literal in a strong sense (as shown above). Invoking of miracles as an explanation of (partially) natural processes ought rather to happen when relatively unambiguous historical witness claims that a miracle happened, as in the case e.g. of the resurrection of Jesus. The literary characteristics of Gen 2-3 are much more ambiguous in this sense. And if they necessarily must be interpreted as describing such a miracle, it is strange that it did not leave any kind of scientifically detectable traces, especially if Adam was the kind of pre-lapsarian super-human he is often conceived as in traditional narratives. ${ }^{57}$

I think it is a fair reading of Genesis 1-2 that the primary miracle there is creation as such (ex nibilo and by the power of the word of God), not that human beings are created in a basically different or more direct way than other living creatures. An important motivation for claiming the historicity of Adam and Eve in this way is often that it provides a secure grounding for the dignity and rights of all human beings, as well as our common culpability for original $\sin$ by some kind of inheritance. However, a problem is that the model (at least in subcategory one versions) seems to be suggesting that genealogical descent is relevant to who has a share in this kind of humanity or sinfulness, and the door can be left open for very unpleasant consequences in questions relating to racism and a naïve biological understanding of 
sin. ${ }^{58} \mathrm{~A}$ better approach concerning human dignity, as has been convincingly argued by Monika Hellwig and Daryl P. Domning, is to underscore that 'the boundary that marks the distinction between the human and other animals need not be sharp to be real and consequential.' 59 It does not require miraculous divine intervention.

It is also a matter of discussion whether type three resonates more easily with the traditional narratives sketched at the beginning of this article than type four. The first human couple becomes so in a very revised sense, perhaps not being able to bear the theological implications that the traditional narrative used to carry. Swamidass' genealogical hypothesis clearly affirms that it scientifically requires a substantial population of 'biological humans' outside the Garden. The biblical texts alluded to in order to justify this claim can in my view hardly be taken to refer to such a population, talking of Nephilim, giants and sons of God (Gen 6:1-4) - not anything close to humans of the same biological makeup as Adam and Eve. Cain's wife and the inhabitants of cities outside the Garden is a better basis, but the narrative of Genesis still claims quite straightforwardly that there was no human being before the creation of Adam (Gen 2:5).60 Swamidass' use of the term monogenism also becomes quite contraintuitive. The 'people outside the Garden' who according to evolutionary science made the proposed 'monogenism revised' of a genealogical Adam and Eve possible, did not themselves rise through monogenism.

The traditional connection between human sin, suffering and physical death (e.g. the pre-lapsarian state) is also lost in type three (as in all the other types). Thus, it might seem that the hermeneutic strength of type three regards only hermeneutics of biblical literacy and authority when they are applied selectively and does not besides that have notably more theological explanatory power than type four. My tentative conclusion regarding type three is that it is scientifically possible, but scientifically implausible (or, scientifically strictly not assessible). The theological support for the view, however, is not strong enough to make it very attractive as a comprehensive alternative. It is in a fundamental way arbitrary in what it takes for granted as needing to be interpreted literally in the Scriptures.

I have thus ended up assessing types one through three as not plausible in different degrees. That does not imply that type four is totally convincing or logically necessary, but it seems to be the best possible explanation of the data I am currently aware of from science and theology.61 I will therefore end by a suggestive further articulation of such a view, in dialogue with some central possible objections.

Ernst M. Conradie articulates an attractive version of type four, the entrance of sin to the world as a gradual process connected to the evolutionary rise of humankind, in Redeeming Sin (2017).62 The aim of the book is to retrieve Christian sintalk in the discourse concerning current environmental problems, but he also goes quite far in discussing what has went wrong in the world. A central notion in his proposal is the distinction between different levels of complexity in the evolutionary process and their connection to the questions discussed here. He speaks of 'bifurcations' that happened both before, during and after the transition into human beings:

At each level of emerging complexity in (human) evolution, what may 
retrospectively be considered to be 'good' (reaching maturity) or 'bad' (undermining a process of maturation) is not pre-determined. Bifurcation (in the sense of things going 'right' or 'wrong') is possible but not necessary at each level of complexity in an ongoing process apparently aimed at reaching relative maturity appropriate to that level. Bifurcation at a given level of complexity will set parameters for any further levels of complexity but does not determine further bifurcations. Only at some levels of complexity such bifurcation may, retrospectively, be judged in economic, moral, religious or theological terms. ${ }^{63}$

The concept of maturation is drawn from the theology of the Church Father Irenaeus of Lyon (c. 125-c. 203) and theologians following him. ${ }^{64} \mathrm{He}$ thought that the first human pair in paradise was created with a childlike innocence, and was intended to grow. This is a notion that can fit very well with modern evolutionary cosmology. Furthermore, by emphasizing the relative 'freedom' of each level of complexity even if they in a certain sense follow upon and determine another, Conradie also opens the possibility of maintaining the traditional Augustinian notion that human beings at some time were able not to sin (posse non peccare). In Conradie's version this means only minimally that they were never forced into sinning by some kind of necessity; it does not necessarily mean that human beings at some point were in a very different and less vulnerable position with respect to sin. The only principal difference between the first human sinner(s) and later generations of sinners would be the difference of not having (accountable) sinners as biological and sociological parents, however much or little that entails.
A gradual view of how sin entered the world needs to be accompanied by a nuanced view of the close connections between human beings and our pre-human predecessors when it comes to sinful behavior. As pointed out by Michael J. Chapman, 'humans are predisposed to misbehaviors (..) because of our evolutionary history'.65 Human beings always have been (from the transitional phase[s] into our species until now) genetically disposed for sinning through their evolutionary heritage. This fact, however, does not mean that human beings are not accountable for sin, from our origins until now, because when human beings became aware of what they were doing, and that they could refrain from doing wrong or evil things or damaging their relationship with God, they were accountable spiritual beings and responsible moral agents (cf. the fall as knowledge of good and evil in the Genesis narrative). Thus, this evolutionary heritage is perhaps not a greater problem for avoiding blaming God for sin than traditional versions underscoring $\sin$ as a possibility in the pre-lapsarian state. The snake was in the Garden, after all. Together with this notion of accountability, it is plausible to connect the rise of human sin within the world with higher levels of complexity concerning consciousness of self, of the human other and his/her dignity, and of God as benevolent creator and the human relation to God. 66

There are pointers in the direction of this almost purely hypothetical character of the 'pre-lapsarian' state of posse non peccare both in the biblical narrative and in pre-enlightenment and pre-Darwin theological reflection. In the Genesis narrative, there is nothing notable happening between the creation of man and his woman before they both disobey the only 
prohibition he ever received. Adam wasn't very long in Paradise! An example is the Church Father Maximus the Confessor (c. 580-662), who was a sharp critic of Origen's theory of a pre-creational fall with creation itself as a kind of consequence of this fall. ${ }^{67}$ Thus Maximus emphasized that the fall into sin happened after God had created everything, inside the created realm. However, he still says that man fell when he was created (hama to ginesthai - 'together with the act of coming into existence'), as to underscore that the pre-lapsarian state is of a more principal and hypothetical kind than a period of notable duration. 68

An important question facing type four views of the story about how $\sin$ began is how it resonates with the eventcharacter and thus the historical contingency of the fall. As Cavanaugh and Smith points out, it may seem to be crucial for traditional doctrine that the nature of the Fall is 'historical' or 'event-ish' ${ }^{69}$ Thomas A. Noble, for example, strongly argues that the Fall must be 'an event within the created realm', adding that it must be a single event. ${ }^{70}$ For reasons of upholding the contingency of sin I fully appreciate the notion inherent in the first point that sin happened within creation, but I think it is worth asking with Daryl P. Domning whether the second is not an 'unexamined assumption' left over from traditional narratives that must not necessarily follow from a reading of the biblical texts and a dogmatics of sin as contingent attentive to natural science. ${ }^{71}$

A short visit to Paul Ricoeur can perhaps help here. He speaks of an 'extreme contraction of the origin of evil into one point' in the 'Adamic' myth' (we could add, also in traditional narratives based on it), that 'emphasizes the irrationality of that cleavage.' But it is still narratively spread out into a 'drama which takes time', thus suggesting that the point is not the duration of the 'event' as short or long. ${ }^{72}$ Thus, I suggest, human beings started to sin when they became evolutionary capable of doing so, and has continued doing so from that time on. ${ }^{73}$ The duration or historical frequency (or how many times it happened) of the event(s) is strictly irrelevant to the doctrine of sin, and there are good reasons to think that we will never be able to describe exactly when, how or how many times it happened. What we know is that it happened to human beings and affects us all.

Gregory A. Peterson argues that '[i]n an evolutionary framework, it might be more accurate to speak not of "the fall' but of falling,' thus resonating well with my argument so far on the gradual entrance of sin. However, he also adds that this falling in a comprehensive picture could not be seen only as a falling down (from some original heights) but also as a falling up. The bifurcations into new levels of complexity in human evolution are always double edged, while opening possibilities of heightened goodness, they may also be used to maximize evil. So there is a certain risk and fragility involved in the special attributes of human beings - the higher you are climbing, the farther down might you fall. ${ }^{74}$ This is a dynamic well recognizable from use and misuse of modern technology and globalization. This way of putting it resonates well both with an Irenean model of maturation and the Genesis story, where the Fall leads to gain as well as pain, heightened knowledge as well as expulsion from the Garden by the grace of God.

A last objection to the view of the entrance of sin into the world as a gradual process to be treated only briefly here (relative to its complexity and contro- 
versy) is the one from biblical (apostolic) authority. What about the claims of Paul and other NT passages concerning Adam? Do they not presuppose a historical, personal Adam and his single Fall? How then could we reject that? My first response to such questions is to take a step back and reflect briefly on the level of acuteness of the problem. There is currently much contextual emotional pressure and in some circles ecclesial constraints connected to the question of the historical Adam as case of biblical authority, but it can be argued that there are similar cases concerning biblical authority which is not felt as having the same kind of urgency. Different strands of Christians today are often well accustomed to think that passages in the OT are accommodated to the language and system of knowledge current at the time. E.g. the Earth is not flat, does not rest on pillars, and there is no underworld beneath our feet, even though some biblical texts seem to claim such things. ${ }^{75}$ There is no good reason to hold that the case is totally different in the NT. For example, almost no-one holds the view today that evil spiritual powers rest literally in the 'air' or the atmosphere closely above the earth (gr. aer, see Eph. $2: 2$ ), that the seed of the mustard tree is literally the smallest of all seeds (see Mark 4:31, where Jesus seems to be claiming that), or that nature itself teaches that long hair is shameful to a man (1 Cor 11:14). These are all questions where the interpretation and application of Scripture is usually informed by science or common sense in a quite straightforward way, without suggesting that it thereby undermines apostolic authority. ${ }^{76}$ Thus, we should at least be open to the possibility that Paul and other NT authors express ideas that are of theological relevance together with 'facts' that are not viewed as facts by modern readers.

When it comes to evolutionary biology and human origins, as provocatively put by Scot McKnight, Paul 'could not have and therefore did not know better.'77 The reason is that all human communication happens within a cultural context, or put more theoretically: every true proposition must be placed in a theoretical framework. ${ }^{78}$ It is fully possible, however, that propositions expressed within a theoretical framework including certain scientific or other knowledge from a given cultural position in space and time, can be true even in other theoretical frameworks. In the case of Jesus, this kind of inculturation to the cultural theoretical framework of his day (e.g. concerning a global Noahflood, or the authorship of OT texts) can be seen Christologically as following from his full humanity. It is impossible to be fully human separated from any concrete, historical and cultural context. Whether this was something he in his divine-human person was aware of, merely accommodating what he said to his hearers, we will never now. In the history of ideas, one cannot expect people to answer questions that was not yet raised, or to adjust their theological reasoning to scientific insights yet not gained. Yet one does not therefore need to conclude that they were completely wrong, for relative to their theoretical framework their reasoning might have been all good. The question of whether Paul believed in a historical Adam is thus perhaps not the most important one. He did probably believe in Adam in a more 'historical' sense than most people today, but the distinctions between historical, figurative, mythological etc. approaches to primeval history in the modern sense was not known to him, because at the time there was little scientific knowledge available 
about this part of history. A central task would therefore be to analyze not only the literal content of apostolic sayings, but also their meaning and motivation, and how they connect to other notions, even in the case of Adam and the fall.

McKnight, citing Paul Achtemeier, points out some important aspects of Paul's reasoning regarding Adam:

'The universality of human mortality is Paul's empirical proof of the universality of human sin.' That is, Paul knows from Genesis that sin leads to death, and since all die, he knows that all $\sin .79$

If that is the case, the historicity of Adam is not a strict necessity for Paul's articulation of the meaning of the redemption given in Christ. The meaning of the figure of Adam in Paul's reasoning is that all human beings are mortal sinners in need of redemption. A contemporary account of a gradual entrance of sin into the world could ground that concern just as well.

We can thus think that Paul and other NT author express their views - views with real theological implications that should be integrated into contemporary systematic theology - within ancient theoretical frameworks containing notions that we today have better knowledge of in e.g. scientific or historical terms. I suggest that Paul would have expressed himself in other ways concerning Adam today, within a theoretical framework suitable for communication of the Gospel in our world, including the best available contemporary knowledge of evolutionary biology and genetic science, as well as the historical context of Genesis. Regrettably, however, we will never be able to ask him.

The question in the end is perhaps: what is the greater problem for our theo- logical systems? That minor adjustments are made to traditional notions in some corners about apostolic authority, cultural frameworks and historicity, or that the thinking about the hermeneutical relation between science and theology must be changed by claiming that Paul or other NT writers forces us to hold views that are at the end of the day highly implausible in light of the best of contemporary science? ${ }^{80}$ I think that the first alternative is the most viable in the long run, because it is most in accordance with my hermeneutical principles building on Augustine, and also the most faithful to Scripture, bringing Scripture into a real conversation with us and everything we do, know, think and believe.

\section{Conclusion}

In this article, I have surveyed different attempts to answer the question of how sin entered the world, attentive to current natural scientific knowledge of human origins. I first noted some plausibility problems for traditional narratives of the fall and original sin facing modern science, most recently (population) genetics, which rejects the possibility of monogenesis in the traditional sense and questions the reality of a pre-lapsarian state. Then I noted four central elements of the doctrine of sin that needs to be taken into account when trying to re-think traditional narratives in a contemporary systematic theology that faithfully reworks the tradition. These included that $\sin$ is a reality, that all human beings are sinners, that $\sin$ is our fault, not God's, and that things did not or do not have to be this way. By way of summary: sin is a contingent, created reality that is not metaphysically or otherwise necessary.

Then I described four currently proposed types of views attempting to describe 
human origins and the entry of sin to the world. A first type refuses the question by avoiding answering it, making instead an existential interpretation of the Genesis narrative. A second type places the first human couple and their 'fall' way back in hominin time. A third type suggests that Adam and Eve in some sense was historical human beings, created de novo or in some way endowed with a new relationship with God, before falling in some kind of historical event. They may have interbred with other creatures of the time, and thus become the genealogical (but not genetic) ancestors of all later human beings. There are also group versions and more figurative versions of this type, where Adam and Eve are representatives or stands for a group of early human beings. The fourth type is to view the entrance of sin into the world as a gradual process closely connected to the evolutionary rise of humankind. After discus- sion of type one through three concluding that they are all in some degree implausible, I articulated a version of type four drawing on the work of Ernest M. Conradie, and in dialogue with some possible important objections to this way of thinking.

In order to gain a more comprehensive understanding of the doctrine of $\sin$ attentive to natural science and other relevant human knowledge, other questions that could not be handled here must be pursued as well. Among them are questions about what kind of problem sin is, what our common status as sinners entails, the relation between individual and collective aspects of the doctrine, and traditional ecumenical disagreements on the understanding of sin. The challenges raised by natural science may be an impetus to further work on the doctrine of sin also regarding such questions. ${ }^{81}$

\footnotetext{
Notes

${ }^{1}$ In my understanding this excludes young-earth creationist views from discussion in this article, because I find them at odds with a great range of concrete empirically based, sound natural scientific reasoning in many disciplines.

2 Wolfhart Pannenberg says: 'No other theme in Christian anthropology has been so obscured for us today than that of sin and our approach to it', (the first sentence under the heading ' $\mathbb{\$} 3$. Sin and Original Sin'), Systematic Theology, vol. 2 (Grand Rapids: Eerdmans/Edinburgh: T\&T Clark, 1994), 231. Pannenberg is not only concerned with science-theology issues, but that is an important part of the complex picture he refers to.

3 As I have shown in Gunnar Innerdal, 'Troens troverdighet. En drøfting av apologetikkens oppgave og plass i systematisk teologi', Teologisk Tidsskrift 1, no. 4 (2012): 419-436, this can be viewed as undertaking an apologetic task, or as having an apologetic concern within systematic theology.

4 This question is highly relevant to the doctrine of original sin (as some kind of inheritance or consequence of the origin of $\sin$ ), but the content of that particular doctrine will not be elaborated on in this article.

5 See e.g. C. John Collins, Reading Genesis Well: Navigating History, Poetry, Science, and Truth in Genesis 1-11 (Grand Rapids: Zondervan, 2018), 232. Cf. Stephen Greenblatt, The Rise and Fall of Adam and Eve (London: The Bodley Head - Penguin Random House), 2-3; and first paragraph of Rebecca Randall, 'What If We Don't Have to Choose Between Evolution and Adam and Eve?' Christianity Today Jan 30, 2020, see https://www.christianitytoday.com/ct/2020/january-web-only/genealogical-adam-eve-evolution-joshua-swamidass.html. Joshua S. Swamidass himself does not include the intuitive sense of monogenism in his version of the traditional narrative, claiming he has most of theological history on his side. Joshua S. Swamidass, The Genealogical Adam and Eve: The Surprising Science of Universal Ancestry (Downers Grove: IVP Academic, 2019), 5 et al. I think he is wrong, but it is not possible to establish that statistically or otherwise in this context, except through the glimpses of historical examples given.

6 How perfect this perfection was is a matter of dispute. The traditional theological consensus is that this original state was perfect at least in the sense of much better than the world we experience now, and without any kind of specific lack or content that questioned it from being 'very good' (Gen 1:31).

7 Swamidass, again, alters the traditional narrative by placing sinlessness and the possibility of immortality within a Garden in the midst of a world with wrongdoing (perhaps not sin in the strong sense) and (at least physical) death present. Genealogical Adam and Eve, 178 Table 14.1, 205 et al.
} 
8 I have put the word 'fall' in quotation marks just to underscore its utterly metaphorical sense (in the traditional western-Augustinian use as well as in theology standing in dialogue with modern science). See e.g. Ernst M. Conradie, Reedeming Sin: Social Diagnostics Amid Ecological Destruction (Lanham: Lexington Books, 2017) 136; cf. also Collins, Reading Genesis Well, 177; 227-233.

9 A similar summary of the different aspects included in the concept historical Adam is made by Scot McKnight in Dennis R. Venema and Scot McKnight, Adam and the Genome: Reading Scripture after Genetic Science. (Grand Rapids, Brazos Press, 2017), 107-108. Note that my summary is by purpose made without making explicit claims that presuppose an in a strong sense literal interpretation of the texts concerning the creation of man (or other creatures) and the Eden story in Gen 1-3. I have also put the word narrative in plural ('traditional narratives') to make explicit that I do not refer to any single very particular view on each of the issues or notions involved. Instead, I am referring to a type of views that can be reasonably thought of as belonging to a group because they agree to a certain degree on the most important things.

10 Some important examples include The 1529 Augsburg Confession art. II on original sin and its transmission from Adam; The 1577 Formula of Concord art. II on the status of the human will before and after the fall; The 1993 Catechism of the Catholic Church \$ 391, 391 \& 399 on Adam and Eve as our 'first parents'; and the canons of the 'Augustinian' 418 Council (or Synod) of Carthage on bodily death as a consequence of $\sin$.

11 They have of course also been questioned for other reasons and at earlier times, but that is not my concern here. For suggestions in other fields, se Tatha Wiley, Original Sin: Origins, Developments, Contemporary Meanings (New York: Paulist Press, 2002), 206-207. A through account of some of the problems at the intersection of traditional narratives and contemporary science can be found in John Schneider, 'The Fall of Augustinian Adam: Original Fragility and Supralapsarian Purpose', Zygon 47, 1 (2012): 949-969.

12 For a through account of this point, see Conor Cunningham, Darwin's Pious Idea: Why the Ultra-Darwinists and Creationists Both Get It Wrong (Grand Rapids/Cambridge: Eerdmans, 2011). 13 See e.g. Peter C. Bouteneff, Beginnings: Ancient Christian Readings of the Biblical Creation Narratives (Grand Rapids: Baker Academic, 2008).

14 Cf. e.g. how Dietrich Bonhoeffer repeatedly stresses that our position in the middle (of an already sinful world) makes it impossible (and perhaps not desirable) for us to access the beginning, in Creation and Fall.

15 The word system is here used in a loose sense, as what is the result of having done systematic theology, roughly equivalent to comprehensive position.

16 Cf. Innerdal, Gunnar, 'Bibelsynets systematisk-teologiske sammenheng.' Theofilos Supplement no. 1 (2015): 20-32, and 'Troens troverdighet', 425-426.

17 (St.) Augustine, The Literal Meaning of Genesis, 18,37. Available among others in Ancient Christian Writers, vol. 41. Translated and annotated by John Hammond Taylor, S.J. (New York: Paulist Press, 1982). 18 Holmes Rolston III, Science and Religion: A Critical Survey (Philadelphia and London: Templeton Foundation Press, 2006), p. ix.

19 (St.) Augustine, The Literal Meaning of Genesis, 19,39.

20 A similar stating of this point: 'If indeed [the 'books' of] nature and Scripture have the same author, as Christians affirm, then there cannot, ultimately, be any disagreement between what we 'read' in one book and what we read in the other. The problem, of course, is that our 'reading' of either book is not perfect. Science does not yet have a full picture of many aspects of the natural world. Similarly, our exegesis and hermeneutics are not infallible. As a result, there may appear to be conflict between science and Scripture, and it may take a long time to sort out apparent disagreements as we wait for improvements in science and theology.' Venema in Adam and the Genome, 8. Cf. the remarks on 'all truth as God's truth' in the introduction to Douglas J. Moo, 'The Type of the One to Come: Adam in Paul's Theology', lecture as part of Adam and the Fall, Creation Project at Henry Center. Available at https://henrycenter.tiu.edu/resource/the-type-ofthe-one-to-come-adam-in-pauls-theology/ (accessedible 05.09.2019)

21 For a more thorough discussion of some points made in this paragraph, see Peter Harrison, 'Is ScienceReligion Conflict Always a Bad Thing?: Augustinian Reflections on Christianity and Evolution,' in in Evolution and the Fall, ed. James K. A. Smith and William T. Cavanaugh (Grand Rapids: Eerdmans, 2017). 22 Cf. many of the works referred to and their pre-history, as well as, e.g. the conference Adam, the Fall, \& the Goodness of God, at Henry Center March 22-23, 2019. To be noted in passing is that the later generations of mainstream Lutheran theologians has not regarded these questions as so significant as in the current discussion, having its center of gravity within Evangelicalism in the US. A recent example of this attitude can be found in Eva-Lotta Grantén, Utanför Paradiset: Arvsyndsläran i nutida luthersk teologi och etik (Stockholm: Verbum, 2013), esp. 44-47, where Grantén without further discussion goes far in rejecting any kind of historicity connected to the Genesis account, relying on the German biblical scholar Claus Westermann. See also Philip Hefner, 'Biological Perspectives on Fall and Original Sin', Zygon 28, 1 (1993): 77-101. In my judgment, this difference is mainly due to different dominant frameworks concerning how to relate creation and redemption, science and theology, and questions about biblical authority. My discussion in this article purposefully discusses questions with the context of Evangelicalism strongly in view, without 
for that reason suggesting that it is necessarily something wrong with the approach of Lutheran theologians (often situated in a European context) framing the discussion in another way. But the discussions in this article are relevant also Lutheran contexts because it concerns new scientific findings that has a bearing on what are the possible alternatives in this part of the science-theology discussion. An earlier version of a similar discussion is the back-and-forth debate between Per Lønning and Anders J. Bjørndalen in the Norwegian journal Tidsskrift for teologi og kirke in 1966. The most significant changes of premises in their discussion contra today, is new developments in genetics and OT hermeneutics and source criticism.

23 Venema in Adam and the Genome, 4 and 55. My emphasis. In the words of his co-author Scot McKnight: 'that you and I, and the rest of humans for all time, come from two solitary individuals, Adam and Eve[:] Genetics make that claim impossible' (xi). My emphasis. Collins puts the point a little more carefully: 'it has become common among geneticists to infer not only that humans share common ancestry with the apes but also that the initial human population is much larger than two.' Collins, Reading Genesis Well, 232. A popular account of recent mainstream genetical research can be found in Adam Rutherford, A Brief History of Everyone Who Ever Lived: The Stories In Our Genes (London: Orion Publishing co. 2016). Also available in U.S. version: A Brief History of Everyone Who Ever Lived: The Human Story Retold Through Our Genes. New York: The Experiment, 2017.

24 The discussion leading to this conclusion happened mainly in a mile-long discussion thread at Biologos forum: https://discourse.biologos.org/t/adam-eve-and-population-genetics-a-reply-to-dr-richard-buggs-part1/37039/1064 (accessed March 4, 2019). Venema sums up his view in the podcast available at https://www.apologeticscanada.com/2018/11/30/adam-and-eve-and-the-human-genome-an-interview-withdennis-venema/ (from about 29:50; accessed March 3, 2019).

25 These are not humans in the sense applied by Venema in the book, equaling anatomically modern human beings, possibly appearing as far back as about 300000 years ago. It is notoriously difficult to define the boundary between human and non-human in this context, specially scientifically (because all species boundaries in evolutionary history are more or less arbitrary dividing lines through gradient changes), but also theologically (where to draw the line between humans and hominins, why and with what consequences). 26 Again at https://discourse.biologos.org/t/adam-eve-and-population-genetics-a-reply-to-dr-richard-buggspart-1/37039/1064.

27 Ian McFarland, In Adam's fall: A Meditation on the Christian Doctrine of Original Sin (Chichester: Wiley-Blackwell, 2010), 143. The words are used with reference to the passages from Augustine discussed above in a footnote. McFarland does not claim that this is Augustine's view of the concrete matter, but tries to apply Augustine's hermeneutical criteria to the scientific situation today, which Augustine for obvious reasons could not. In the context McFarland also includes issues about evolutionary theodicy. I do not have space to go into that question in this article. Attempts at that can be found in Christopher Southgate, The Groaning of Creation: God, Evolution and the Problem of Evil (Louisville: Westminster John Knox Press, 2008), or in Asle Eikrem and Atle Ottesen Søvik, 'Evolutionary theodicies - an attempt to overcome some impasses', Neue Zeitschrift für Systematiche Theologie und Religionsphilosophie, 3, (2018:) 428-434, preprint available at https://atleottesensovik.mf.no/Filer/Publikasjoner\%20før\%202018/Evolutionary\%20theodicies\%20preprint.pdf (accessed March 8, 2019).

28 A good description of this task is found in William T. Cavanaugh \& James K. A. Smith, 'Introduction: Beyond Galileo to Chalcedon', in Evolution and the Fall (Grand Rapids: Eerdmans, 2017). They summarize: 'the church will have to collectively discern what constitutes a faithful extension of the tradition. Perhaps we might determine that the picture of a historical couple lapsing in a single episode is not essential. But we might also discern that making fallenness basically synonymous with finitude violates the 'core' of the traditional doctrine,' p. xxv. Cf. a similar understanding of this theological task in Nicholas Olkovich, 'Reinterpreting Original Sin: Integrating Insights From Sociology and the Evolutionary Sciences,' The Heythrop Journal, LIV (2013): 715-731.

29 This is the main approach taken in Patricia A. Williams, Doing without Adam and Eve: Sociobiology and Original Sin (Minneapolis: Fortress Press, 2001). A similar account to mine so far of the history of traditional narratives, their problems and the possible paths forward can be found in Wiley, Original Sin, 1 and passim, cf. also Conradie, Redeeming Sin, 131. Wiley, however, rejects the historicity of traditional narratives of Adam and Eve, and constructs a doctrine of original sin that is grounded (only) in an analysis of the present human situation as sustained inauthenticity, drawing especially on Bernhard Lonergan (see ch. 8). Thus she is not much interested in the question put in the way I do in this article.

30 As Dietrich Bonhoeffer puts it, "[the church] views the creation from Christ; or better, in the fallen, old world it believes in the world of the new creation, the new world of the beginning and end, because it believes in Christ and nothing else.' Creation and Fall: A Theological Exposition of Genesis 1-3. Dietrich Bonhoeffer Works, vol. 3. (Minneapolis: Fortress Press, 1997), 22 (the volume is a transcript of Bonhoeffer's lectures at the University of Berlin, 1932-33). Already the Church Father Ireneus (ca. 200 AD) suggested that it is Adam that is modelled on Christ, not the other way around, se Bouteneff, Beginnings, 81-82. 
31 See T. A. Noble, 'Original Sin and the Fall: Definitions and A Proposal,' in R. J. Berry and T.A. Noble, eds. Darwin, Creation and the Fall: Theological Challenges (Nottingham: Apollos/InterVarsity Press, 2009), 112-113.

32 That this is a basic insight in the doctrine of sin is emphasized e.g. by Jan-Olav Henriksen (referring to John Haught), in Life, Love and Hope: God and Human Experience (Grand Rapids: Eerdmans 2014), 262-3n49; and Conradie, Redeeming Sin, 76 and passim.

33 This is almost surely the better interpretation of the Greek phrase eph' ho in Rom 5:12: not that everybody sinned 'in' that one human being (so Augustine and many other Latin writers, following the Latin Vulgate translation), but that all are sinners subject to death 'because' they (like that one human being) have all sinned themselves. See e.g. McKnight in Adam and the Genome, 173; 184-188.

34 Bonhoeffer, Creation and Fall, 105.

35 This is a central claim in the theodicy developed by Atle Ottesen Søvik. Se The Problem of Evil and the Power of God (Leiden: Brill, 2011) and later works.

36 Cf. Bonhoeffer, Creation and Fall, 139.

37 As Collins, Reading Genesis Well, 229, points out, the expression might well be an allusion to or an echo of Wisdom of Salomon 2:23-24.

38 Cf. The 5-model list presented in Bjørn Are Davidsen and Atle Ottesen Søvik, Evolusjon eller kristen tro? - Ja takk, begge deler!: Om fornuft, vitenskap og tro, De store spørsmålene \#2 (Follese: Efrem forlag, 2016), $167-168$, can serve as a reminder that there are other legitimate ways of mapping the alternatives and framing this discussion. Other mappings of alternatives can be found in C. John Collins, Did Adam and Eve Really Exist? Who They Were and Why You Should Care (Wheaton: Crossway, 2011), and Denis Alexander, Creation or Evolution: Do We Have to Choose? Second edition (Oxford: Lion Hudson, 2014), chapters 10 and 12 .

39 Most thoroughly in Kirkegaard alias Vigilius Haufniensis, The Concept of Anxiety. There is also relevant material in Kierkegaard alias Anti-Climacus, The Sickness Unto Death. For reasons of space I am not able to go into a substantial discussion about Kierkegaard's position here, and only refer to him through secondary literature. For discussions of Kierkegaard's view see McFarland, In Adam's Fall, 43-44 and Knut Alfsvåg, Christology as Critique: On the Relation between Christ, Creation and Epistemology (Eugene: Pickwick Publications, 2018), 135-145.

40 See Bonhoeffer, Creation and Fall. Aaron Riches expresses a similar position in 'The Mystery of Adam: A Poetic Apology for the Traditional Doctrine' in Evolution and the Falln, ed. James K. A. Smith and William T. Cavanaugh eds., Evolution and the Fall (Grand Rapids: Eerdmans, 2017). Riches says that Adam 'is the first being of human history', but because he is proto-logical, part of proto-history he 'cannot be investigated by historical methods' (p. 123). It sounds a bit incredible to me that something historical cannot be investigated by historical methods.

41 In the words of Conradie: 'To err may be human, but if sin is 'natural,' then the contingency of sin and salvation can no longer be maintained.' Redeeming Sin, 97, cf. 110, and 133: '..even if the fall is regarded as a myth, such a myth needs to help one to make sense of where and how things have gone wrong. (...)

The question of plausibility [..] cannot be avoided unless one wishes to argue that nothing has gone wrong, or that things have always been wrong and that there is no specific human culpability for what has gone wrong.' And further: 'The postulate of a historical fall is therefore, it seems to me, an essential requirement for (an Augustinian understanding of) the Christian faith, even if the fall as a historical event can no longer be located in the Eden narrative, interpreted as literal history' (p. 135). Similarly George L. Murphy, 'Roads to Paradise and Perdition: Christ, Evolution, and Original Sin,' Perspectives on Science and Faith, 58, 2 (June 2006): 112, says: 'the claim that Adam is not a historical individual in the modern sense does not mean that Paul is talking only about the existential situation of all people, or that the origin of sin is not in view in the text [Rom 5].'

42 Young Earth Creationism is similar to this type, but with another timeframe, because it has not the same need of making Scripture and contemporary science say the same thing.

43 Cf. the discussion between Dennis Venema and Richard Buggs referred to above.

44 A recent example of this type of view is found in Hössjer, Ola, Ann K. Gauger and Colin R. Reeves, 'An Alternative Population Genetics Model,' in Theistic Evolution: A Scientific, Philosophical, and Theological Critique, ed. J. P. Moreland et. al. (Wheaton: Crossway, 2017), 503-521.

45 This will often mean about 6-10-12 000 years ago, referring to the context and/or chronology of Genesis, but other timeframes are also possible.

46 'Some kind of historicity' here includes ideas from Adam and Eve as concrete individual human beings, to notions of the text as figurative or using pictures, but 'there are actual events that the pictures refer to' C. John Collins, 'Adam as Federal Head of Humankind,' in general ed. Stanley P. Rosenberg ed. Finding Ourselves After Darwin: Conversations on the Image of God, Original Sin, and the Problem of Evil, general ed. Stanley P. Rosenberg (Grand Rapids: Baker Academic, 2018), 151. 
47 E.g. in John Stott, Understanding the Bible, Expanded edition (Grand Rapids: Zondervan, 1984), 55-56. A more recent adherent is Tim Keller, e.g. in this Gospel Coalition video: https://www.thegospelcoalition.org/article/keller-moore-duncan-non-negotiable-beliefs-about-creation/ (accessible 29.09.2019).

48 Most thoroughly in Swamidass, Genealogical Adam and Eve, which collects and develops several earlier articles and posts from his blog Peaceful Science (see the bibliography of the book for details). Although it is genetically possible that all human beings share common ancestors in this genealogical sense, it is almost impossible that we do so in only one couple, it is more likely the case that we all are related through several couples at different points in history (this also holds for models adhering to mainstream population genetics). Adam and Eve is thus of theological significance only, not having any kind of scientific impact or plausibility beyond them being (probably) possible at a date and place close to the Genesis narrative.

49 That may be taken as a deviation from the literal sense of 1 Cor 15:45, saying that Adam was the first human being (anthropos).

50 For an explanation of the term, see Swamidass, Genealogical Adam and Eve, 130. He later (133-135) makes a distinction between those people as biological humans, while the lineage of Adam and Eve are also textual humans (those who are of real concern in the biblical text).

51 C. John Collins, 'Adam as Federal Head', 158.

52 Cf. The discussion of the passage in Collins, Reading Genesis Well, 230-1. Collins may be making much of little evidence; putting too much weight on biblical theology and less on linguistics and historical hermeneutics.

53 See Smith, 'What Stands on the Fall?: A Philosophical Exploration,' in Evolution and the Fall, ed. James K. A. Smith and William T. Cavanaugh eds., Evolution and the Fall (Grand Rapids: Eerdmans, 2017), esp. 61-62. Similar reasoning from a Catholic perspective can be found in Murphy, 'Roads to Paradise and Perdition,' 115-116, and from a Lutheran perspective in Robert Jenson, Systematic Theology: The Works of God, vol. II (Oxford University Press, 1999), 150.

54 Conradie, Redeeming Sin. Per Lønning argued something similar in his contributions in Tidsskrift for teologi og kirke (TTK), 1966. Lønning's position also has elements of type one in it. Joel B. Green, “Adam, What Have You Done?': New Testament Voices on Original Sin,' in Evolution and the Fall, ed. William B. Cavanaugh and James K. A. Smith eds., Evolution and the Fall, (Grand Rapids: Eerdmans, 2017) argues that such a scenario is also reconcilable with NT view on original sin.

55 This point is well put by Greg Cootsona in a discussion forum with Swamidass on the web: 'Stated another way, the only reason that we are concerned with this original pair living in Mesopotamia around 6,000-10,000 is our biblical and theological tradition,' from

https://discourse.peacefulscience.org/t/greg-cootsona-mere-science-and-adams-empty-chair/591/18 (accessed March 4, 2019, my emphasis). Swamidass confirms this indirectly in his book by granting the claims of biblical inerrancy of the Chicago Statement and the Lausanne covenant as given presuppositions (without discussion or justification) for his theological working space in dialogue with science. The question of warrant for belief in Adam and Eve turns on (almost only) 'whether we think Scripture is trustworthy, and what we think it is telling us', Genealogical Adam and Eve, 87.

56 These passages include Matt 19:4-5; Luk 3:38; Rom 5:12.14; 1 Cor 15:45; 1 Tim 2:13. An important path that I'm not able to follow at any length here due to space considerations, is whether a traditional reading of these passages are sensitive enough to the Adams and Eves of the Second Temple Judaism context. It is perhaps not totally obvious that Adam as historical person in something close to a modern sense is the only viable interpretation of these passages. See e.g. McKnight's part of Adam and the Genome; Green, “Adam, What Have You Done?", 98-105; Antti Laato and Lotta Valve eds. Adam and Eve Story: In the Hebrew Bible and in Ancient Jewish Writings Including the New Testament. Studies in the Reception History of the Bible, 7, ed. Antti Laato and Lotta Valve (Turku: Åbo Akademi University \& Winona Lake: Eisenbrauns, 2016). As the commentaries show, there is a range of available interpretations of each of the mentioned texts. I cannot go into the details of them here, but I think that the conclusion I draw from the sum of these texts is a straightforward one.

57 Cf. the scene in the 2014 Hollywood film Noab where Adam and Eve has skin shining as from gold. Although I do not suggest that the film is fully representative to the tradition or that this is a plausible interpretation of what Genesis is saying, I think the scene captures important intuitions in traditional narratives about Adam and Eve that are very hard to integrate in a type three view.

58 This point was made by Venema vs. Swamidass at an Adam and the Genome book symposium, see http://henrycenter.tiu.edu/2017/07/response-to-the-symposium-part-1/ (accessed March 4, 2019). A theory of common human descent much more easily goes together with an insistence that all human beings are part of the same 'family'. Swamidass has answered any accusations of implicit racism in his book Genealogical Adam and Eve, granting 'people outside the Garden' full human dignity and rights, even perhaps the image of God. But it remains strange that his distinction between biological humans and textual (biblical, in the 1 ineage of Adam) humans must mean that not all humans were humans in the same sense for quite a considerable time before Adam and Eve's lineage spread throughout the world. In his version of a regional Noahic 
Flood (not literally global as stated in Gen 7:19-20) restricting the Adam and Eve textual human lineage down to 5, it also seems strange that God will have to be punishing people originating outside the Garden together with textual humans for the sins committed by textual humans.

59 See Domning, Daryl P. and Monika K. Hellwig, Original Selfishness: Original Sin and Evil in the Light of Evolution (New York: Routledge, 2006), 136.

60 Swamidass, Genealogical Adam and Eve, 146 tries to counter this objection by saying that Gen 2 refers to a specific place, but the creation of man/Adam happens before the Garden is set up, and v. 4 clearly states that the whole world is within view.

61 A similar judgment is made by Greg Cootsona in his book Mere Science and Christian Faith: Bridging the Divide with Emerging Adults (Downers Grove: InterVarsity Press, 2018) and in this forum discussion: https://discourse.peacefulscience.org/t/greg-cootsona-mere-science-and-adams-empty-chair/591 (accessed March 4, 2019).

62 I have reviewed the book at http://readingreligion.org/books/redeeming-sin (accessedible March 8, 2019).

63 Conradie, Redeeming Sin, 196.

64 On Irenaeus theology of creation - and fall - see Matthew Craig Stenberg, Irenaeus on Creation: The Cosmic Christ and the Saga of Redemption. Supplements to Vigiliae Christianae vol. 91 (Leiden/Boston: Brill, 2008).

65 Chapman, 'Hominid Failings: An Evolutionary Basis for Sin in Individuals and Corporations,' in Evolution and Ethics: Human Morality in Biological and Religious Perspective, ed. Philip Clayton and Jeff Schloss (Grand Rapids/Cambridge: Eerdmans), 109. Chapman later adds that still 'evolutionary theory does not actually support the reduction to deterministic, gene-based explanations' (p. 111). On this point see also Conradie, Redeeming Sin, 91-92; 131-143.

66 See Conradie, Redeeming Sin, 140 for further details. The God-relation of the first human beings/sinners is often a central element in type three views, see e.g. Smith, 'What Stands on the Fall,' 59. While it is possible that the creatures first identifiable as humans were addressed by God with a special kind of revelation, I do not think that is a necessary inference from the Genesis narrative read in a type four way. The revelation starting a new kind of relationship between creatures and God at the dawn of humanity might as well be conceived as a part of 'natural' as of 'special' revelation (to use common terms of Scandinavian Lutheran theology).

67 See Paul M. Blowers and Robert Louis Wilken, ed./trans. On the Cosmic Mystery of Jesus Christ: Selected Writings from St. Maximus the Confessor (New York: Yonkers/St. Vladimir's Seminary Press, 2004), 24. I was made aware of this point through working with a Master's thesis in Greek several years ago, see Gunnar Innerdal, Maximos Bekjenneren: En bok om askese. Oversettelse, innledning og noter (University of Bergen, fall 2010), 100.

68 The relevant texts from Maximus are Ambiguum 42, (Quaestiones) Ad Thallasium 61, cf. Ad Thal. 1. Translation of these are available in Blowers/Wilken, On the Cosmic Mystery, 85; 97; 131. Bouteneff, Beginnings, 121-168 cites the Cappadocians as being very unsure about the character (and perhaps existence) of paradise.

69 Cavanaugh and Smith, 'Introduction,' xxvi. The expressions are used in a summary of Smith's article later in the volume.

70 Noble, 'Original Sin and the Fall,' 114. The same presupposition is made by Swamidass, Genealogical Adam and Eve, 184, speaking of the Fall as a 'single act'.

71 '. .has there not always been an unexamined assumption here: namely, that the universality and the moral character of original sin both necessarily stem form one and the same individual, act, and moment in time?' (not to mention that in the Genesis narrative it is not an individual, but a couple acting...!), Domning and Hellwig, Original Selfishness, 140.

72 See Paul Ricoeur, The Symbolism of Evil, translated by Emerson Buchanan (Boston: Beacon Press, 1969), 243.

73 Cf. McFarland, In Adam's Fall, 160: “Adam' can only be regarded as the first in a series of sinners and not as the unique 'cause' of subsequent human sin.' '...we are all one with Adam, and thus we share with him - and with each other - the same nature, marked by the damaged wills that turns us all invariably and catastrophically away from God.'

74 Cf. Conradie, Redeeming Sin, 217.

75 See e.g. Murphy, 'Roads to Paradise and Perdition', 112 for a short but informed account of this way of thinking. A much read and controversial work on these questions from an Evangelical point of view is Kenton Sparks, God's Word in Human Words: An Evangelical Appreciation of Critical Biblical Scholarship (Grand Rapids: Baker Academic, 2008). Swamidass, Genealogical Adam and Eve, 139 suggests a similar hermeneutic concerning some sayings in Scripture (e.g. 'to the ends of the earth', and a regional, not global Noahic flood), but for some unstated reason it is not an alternative for the biblical passages supposed to be claiming what he adheres to as must-be historical givens concerning Adam and Eve and universal ancestry through them. 
76 On 1 Cor 11, cf. how parts of this text are 'relativized' historically as early as in the Augsburg Confession, art. XXVIII, along with the prohibition of eating blood in contexts with Jewish presence from Acts 15 .

77 McKnight in Adam and the Genome, 189.

78 The concept 'theoretical framework' in relation to truth value is worked out in detail by the German philosopher Lorenz B. Puntel and his American friend and colleague Alan White. See Puntel and White (trans.), Structure and Being: A Theoretical Framework for a Systematic Philosophy (University Park: Pennsylvania State University Press, 2008), and Alan White, Toward a Philosophical Theory of Everything: Contributions to the Structural-Systematic Philosophy (New York: Bloomsbury, 2014).

79 McKnight in Adam and the Genome, 187.

80 Collins, for example admits that '[p]robably there are some scientific problems' with his type three view, see 'Adam as Federal Head of Humankind', 158.

81 An earlier version of this work was presented at the Veritas Research Symposium, NLA University College, Gimlekollen, 19.10.18, and some of the material in a different set up at a research seminar at two day-meeting of Department of Theology, Religion and Philosophy, NLA University College, 05.02.2018. I have also discussed the material with prof. Neil Messer, University of Winchester, and received extensive editorial feedback from Theofilos. I want to express thanks to my colleagues for the responses and input received. 


\title{
Theofilos
}

A Nordic open access journal in Theology, Philosophy and Culture

Published by NLA University College - in partnership with Johannelund School of Theology

Available at www.theofilos.no

\section{The Apologetic Fruitfulness of a Revised Natural Theology}

\author{
Knut-Willy Sather \\ Professor at Department of Religious Studies \\ Volda University College \\ knut-willy.saether@hivolda.no
}

\begin{abstract}
This article explores the epistemological locus of a revised natural theology (RNT) and examines the apologetic fruitfulness of this concept. In the current science-religion dialogue, RNT is advocated by scholars such as John Polkinghorne. I argue in this article that RNT partakes of the nature of faith and can be labelled as theological metaphysics. The apologetic output is then mainly seen as a contribution to constructing a coherent philosophical-theological understanding of reality. For being able to do this, we need to acknowledge a wider epistemological framework for RNT. One step is to rephrase the underlying critical realism to a constructive critical realism. This approach takes better into account the complexity of our reality. Thus, the apologetic fruitfulness can be evaluated against other competitive coherent systems at a transdisciplinary level.
\end{abstract}

Keywords: Revised natural theology, theological metaphysics, constructive critical realism, fideism, foundationalism, coherentism

\section{Introduction}

I $n$ this article, I will problematize the locus of a revised natural theology (RNT) and examine the apologetic fruitfulness of this concept. In the current science-religion dialogue, scholars such as John Polkinghorne argues for RNT. ${ }^{1}$ Such natural theology starts with insight from the scientific endeavor and elaborates this insight into a larger picture of reality. It differs from the old fashion natural theology in several ways. It is more modest, talking about hints and signs, instead of proofs and evidence. It does not emphasize any particular scientific insight but looks at the ground of all science's explanation. The content of a revised natural theology according to Polkinghorne can be summarized is three topics: (1) The intelligibility of nature (2) The fine-tuning of nature (3) The beauty of nature. ${ }^{2}$

By apologetic fruitfulness, I have in mind how RNT tries to make Christian faith reasonable, understandable, and communicable. Polkinghorne uses the phrase 'motivated belief' for his point of departure, and his approach is a mediation on the relationship between science and theology. Such an apologetics also offers an open-minded and critical attitude towards both science and theology that constitutes an insightful case for the truth of Christian faith.

By searching for the locus of RNT, I have in mind how RNT fits into a larger epistemological picture. Such a picture includes both a discussion of what kind of theology RNT is, and a clarification of 
how we can understand RNT in a broader picture of knowledge, including how RNT relates to topics such as critical realism, foundationalism, and coherentism.

I will not map out the specific content of RNT, as this is done elsewhere. ${ }^{3} \mathrm{My}$ agenda is to problematize the RNT itself as a package of thinking. My sub-questions concerning the locus of RNT are twofold: (1) What kind of theology are we dealing with in RNT? (2) How does RNT fit into a larger epistemological picture of our knowledge? Having explored these two questions, I finally address the apologetic fruitfulness of this type of natural theology.

\section{Revised natural theology - what kind of theology?}

RNT is obviously about doing some sort of theology. In my context, I am not searching for particular theologies in the sense as different dogmatic systems or denominational traditions. The clarification of theology I am doing here is, in one sense, more fundamental, by unpacking theology as a field in an interdisciplinary context, namely the science-religion debate. Polkinghorne is relevant for this purpose. He differentiates between systematic theology and metaphysical theology. Systematic theology is: 'the specialist investigation of particular types of experience and insight which we label religious.' 4 This type of theology is comparable with other rational discourses and has a starting point in its own data, namely Scripture, tradition, and reason. Doing this type of theology - labelled as first-order theology - requires an openness and has to be 'prepared to conform to the discovered nature of reality and not shackled by prior prescription of what are the acceptable outcomes of the enquiry.' 5 In Polkinghorne's terms this is doing theology 'bot- tom-up'.

Theological metaphysics, on the other hand, is understood as the great synthesizing discipline which includes first-order rational discourses. Theological metaphysics can be described as a rational discourse with at least one assumption: God's existence. Polkinghorne says theological metaphysics has a starting point in a fundamental principle: belief in God as the ground of being. This kind of theology is also labelled philosophical theology or second-order theology. Theological metaphysics is informed by insight from first-order theology, as well as other fields. When doing theological metaphysics, we try to bring different first-order results (from both science and theology) together and on this basis search for a consistent and coherent picture of the world. ${ }^{6}$ This can be described as the active role of theological metaphysics. In addition, we find a passive role, as theological metaphysics ought to respect different fields which it is informed by. Thus, theological metaphysics tries to stay clear of instructing or correcting specific firstorder insight, such as insight form natural sciences.

It is not directly clear in Polkinghorne's writings what sort of theology RNT is. However, he says RNT partakes of the nature of faith, and I have argued elsewhere for locating RNT to the campus of theological metaphysics. ${ }^{7}$ I find three reasons for this. First, natural theology has always looked closely at what the sciences have been saying about the world, this is also the case for RNT. However, to look closely, is not to relate itself to science in such a way as 'finding God's finger' or filling the 'gaps' with God as an explanation. Hence, RNT tries to avoid the failure of God-of-the-gaps. RNT does not deal with particular occurrences in nature, 
but with the whole ground of the scientific endeavor. Hence, RNT is informed by theories from natural science without overruling them.

Second, the content of RNT (the intelligibility of nature, fine-tuning of nature, and the beauty of nature) is not results from science as data or theories. The insight arises out of the scientific endeavor, but are not explainable within science. This is not God-of-the-gaps, as it is not an attempt to provide theological answers to scientific questions. RNT emphasizes that science seems: 'to throw up questions which point beyond itself and transcend its power to answer.'8 Thus, RNT is a trans-disciplinary interpretation of topics developing from science.

Third, we should not have too strong ambitions concerning what we conclude from such an insight. What we can do, is to be informed by natural science, and bring the insight into a larger interpretive philosophical framework (that is theological metaphysics). From this, RNT cannot claim any universal certainty, as it at least has one assumption: It partakes of the nature of faith in God. Therefore, RNT as a transdisciplinary interpretation does not advocate 'knock down' arguments but strives for a coherent picture if the world.

Such a larger interpretive philosophical framework corresponds with Niels Henrik Gregersen. He argues that the science-religion dialogue is an interdisciplinary dialogue which takes place as a transdisciplinary interpretation of the methods and results from different fields and always involves philosophical questions. ${ }^{9}$ The role of theology of this type, as theological metaphysics, is as an integrative discipline, bringing together insight from different fields into a larger picture. ${ }^{10}$
Thus, in Polkinghorne's concept RNT works as a core link between science and theology, or more precisely: between natural science and theological metaphysics. However, for being able to analyze further such a link, with relevance for how to understand RNT's apologetic fruitfulness, we need to explore the underlying epistemological framework of this type of natural theology. This framework is critical realism. In short, we can say that a critical realistic epistemology makes RNT possible.

\section{Revised natural theology and critical realism}

Critical realism, even limited to the science-religion debate, is a comprehensive topic. ${ }^{11}$ I will not delve deeply into this but clarify a few points with relevance for RNT. In general, critical realism consists of an ontological claim (realism) and an epistemological claim (critical). We need to be aware that critical realism spans over many different approaches, so we actually deal with various critical realisms. My point here is not to analyze varieties of critical realism but problematize the overall position as such in the context of the science and religion debate.

Critical realism in science is not so much a questioned topic; it is critical realism in theology which has been heavily debated.12 Polkinghorne as a critical realist has been criticized for doing a shortcut by taking scientific critical realism as underlying both the scientific and the theological enterprise. Critical realism, as such, has also been criticized for remaining caught in 'modernistic' structures, such as epistemological foundationalism, representational thinking with a correspondence theory of truth, and excessive individualism. ${ }^{13}$ I find the critics of the 'old fashion' critical realism in the science 
and religion dialogue partly legitimate, especially the points problematized by Kees van Kooten Niekerk. In short, he warns us against making short-cuts from critical realism in science to critical realism in theology. Some of his arguments are the following.

First, we have the problem of God as an object. We cannot experience God in the same way as we have sensory experiences in nature. Van Kooten Niekerk says:

theology differs from science in that it is contested whether its core subject matter (God) exists at all. And, of course, [this] affects the plausibility of the reality claims that are contained in theological propositions. ${ }^{14}$

Second, we have the problem that religious experience cannot be subject to testing in the same way as we do experimental testing in science. This point emphasizes the hermeneutical dimension in theology. In one sense, religious experience only exists in the past conveyed through oral or written testimonies. Hence, in these testimonies experience and interpretation are intertwined.

Third, in theology we have to deal with the metaphorical character of the religious language. We express God in metaphors, such as 'father' or 'shepherd'. Further, the metaphorical language expresses God as experienced in and through a personal relationship. Even though we use metaphors and models also in science, they are fundamentally different from what is going on in theology, van Kooten Niekerk says.

In light of these differences, he prefers to use the term 'modified critical realism' in theology. Anyway, a modified critical realism in theology can hardly be justified outside a Christian tradition, as it requi- res a positive attitude to Christian faith in the first place. Van Kooten Niekerk concludes: 'In a fundamentally way it is a question of fides quaerens intellectum (faith seeking understanding), which remains within the context of faith.' 15

Polkinghorne's critical realism does not dissolve the epistemological differences in science and theology, as he pays attention to some of the similar considerations raised by van Kooten Niekerk. However, the epistemological differences are more clearly articulated by van Kooten Niekerk. My reason for acknowledging the differences between critical realism in science and in theology is to emphasize that reality has a many-layered structure. This is not an attempt to advocate a fragmentated view of reality. It is rather the opposite: arguing for a holistic and consistent view of reality which takes into account as best as possible the complexity of the reality in which we try to understand.

My next step is therefore to emphasize more thoroughly an epistemology which pays attention to the many-layered structure of reality. Van Kooten Niekerk's considerations are a necessary first step. However, we need to elaborate this further.

In the science-religion dialogue, Andreas Losch explores a trajectory to solve the challenges with the old fashion critical realism which relies too heavily on an epistemology which is based on how natural science works. He has coined the term constructive critical realism. By doing this, he emphasizes the social and cultural dimensions in our search for knowledge. He says the original critical realism too easily weaves natural science and theology together in one epistemological package. Losch argues for a wider approach to rationality: 'the rationalities 
of natural, social, human science and of course theology are different ones...'16 There must be different rationalities since the objects for these fields are different, and our approach to the objects needs to correspond to the distinctive character of the objects.

Losch develops a broader picture compared with Polkinghorne by including a variety of fields, such as the humanities and social sciences. There are undoubtedly different rationalities involved in our search for knowledge. Losch points out that the traditional critical realism is limited since the distinctive character of different fields has not been sufficiently considered. Losch says: 'The concept of constructive-critical realism assumes that in the process of science (and in its application as well), cultural construction carrying ethical decisions is taking place. ${ }^{17}$ For Losch, our approach to knowledge and our understanding of rationality need to take the 'postmodern challenge' seriously, which in this context gives voice to the cultural and social dimensions in doing science. Thus, such a concept will acknowledge the heritage of modernity as well as the insight from our postmodern context which emphasizes the personal, social and cultural dimension of rationality.

Losch describes the 'postmodern situation' as an opening into new possibilities. He says it opens up space for a new common ground:

Our access to truth is limited; each person can know directly very little of truth and must trust others for the rest. Nevertheless, this limited access to truth represents a common ground on which we can claim freedom and respect. It provides the spiritual foundation of a free society, the achievement of which Polanyi called 'man's cosmic calling'. ${ }^{18}$
At the core of Losch's constructive-critical realism is a two-fold understanding of our search for knowledge. There is a 'constructive direction to shape the world by the use of culture toward the realization of increasing freedom and is, yet, critically aware of its limits: nature's limited resources and sin's diminishment of man's ability of recognition. ${ }^{19}$

The traditional critical realism, advocated by Polkinghorne, can be expanded and adjusted by Losch's constructive critical realism. RNT, as arguing for theism as the best explanation, can benefit from such a broader constructive critical realism. I will emphasize two points based on my analysis above. First, we are not solely 'caught' in modernism, but we relate our epistemology to the postmodern situation. This makes RNT more relevant in dialogue with the current cultural situation. Second, in RNT we do not narrow our focus to natural science and theology but rather expand our approach to include the humanities and other broader fields as well. Our reality is one, but it is many-layered in the sense that we have different approaches with their distinct methodologies in which we try to gain knowledge and insight. In Losch's word, our world is more than physics. RNT can be enlarged by embracing a wider range of fields, and not only being informed by the natural sciences.

In the extension of these two points, a third one with relevance for RNT emerges out of constructive critical realism. The constructive part opens up for a consciousness of the ethical dimension in all search for knowledge. When opening for a constructive critical realistic epistemology in the human sciences, the recognition of its ethical implications cannot be avoided, Losch says. ${ }^{20}$ Thus, our search for knowledge is intertwined with ethical 
decisions. RNT would benefit with a stronger emphasize on the ethical dimension of the purpose of our knowledge, which also has relevance for its apologetic fruitfulness.

\section{Fideism, foundationalism, and coheren- tism}

I will now turn more directly to the apologetic fruitfulness of RNT. As already mentioned, RNT has to be understood as arguing for theism as the best explanation. So far, I have mapped out that RNT is taking place within the context of theological metaphysics and is about a transdisciplinary interpretation of insight from different fields. Theological metaphysics, as well as RNT, assumes the existence of God. This gives us at least one challenge: What is the apologetic fruitfulness of arguing for a theistic belief when the arguments are interpreted beforehand within a theistic framework? Is not theological metaphysics, and then RNT, a self-supporting house of cards, confirming what we already have as assumption(s)? My questions echoes van Kooten Niekerk's observation of the underlying (modified) theological critical realism: The fact that it requires a positive attitude to Christian faith in the first place.

Since theological metaphysics and RNT has at least one assumption, God's existence, we need to clarify this in light of fideism. Broadly spoken, fideism is a position claiming that faith in God is in one sense a God-given gift, independent of reason. Thus, reason is not suited to justify religious faith. Fideism takes many shapes and colors. However, I will emphasize one point in relation to the role of RNT within the context of theological metaphysics. Starting with faith, i.e. belief in God, is something different than starting with specific given theological con- cepts which frames all other kinds of knowledge. The problem with fideism is its tendency to individualism where we all individually claim some sort of infallible information from God. The history of theology has shown us that such claims have fall short. An apologetics weaved together with fideism is not a fertile strategy.

However, theological metaphysics is not fideism. Polkinghorne argues for theological metaphysics as a legitimate taken position informed by different fields. Hence, the role of theological metaphysics is to take seriously the insight from natural science, and I will in company with Losch, include such as the humanities and social sciences. Our insight arises from available data, from testing hypothesis, and by formulating theories, and is not based on prior faith statements or dogmatic claims. My short clarification of RNT as not belonging to the campus of fideism, is partly related to another discussion concerning the structure of knowledge, namely foundationalism and coherentism.

By arguing for RNT with an underlying constructive-critical realism, I will not follow the road of foundationalism, neither the road of relativism. Foundationalism spans over a wide range of positions, and foundationalist theories differ in the kind and degree of dependence they assert, such as strong and moderate foundationalism. ${ }^{21}$ Foundationalism within the context of theology starts with some dogmas, which rely on themselves. ${ }^{22}$ Such a foundationalist view can within the context of theology be related to fideism. Foundationalism represents some obvious challenges, both from a general epistemological point of view and from a more specific theological one.

On the other hand, if we do not start 
with some givens, as in foundationalism in the general sense above, are we then lost in the sea of relativism? In contrast to foundationalism, coherentism is another strategy to structure our knowledge. This can be done without giving up some sort of correspondence to reality (the latter is a core element in critical realism). Coherentism argues that justification of a belief depends on its coherence with other beliefs that one holds. In this picture, our structure of knowledge takes shape as a net, consisting of different kinds of knowledge that in various ways are related to each other. Since such a net runs the risk for being a closed system without reference to the real world (e.g. a fictive world), we need some sort of correspondence or reference to reality. This can be solved in different ways, such as van Huyssteen's postfoundationalism and Gregersen's contextual coherence theory. ${ }^{23}$ The latter argues, by following Nicolas Rescher, for an understanding of data as not givens in the sense of truth, but as immediate truth. Thus, coherentism does not only mean an inner logical consistence between propositions, but also a systematic organization of contextual propositions grown out of experience. ${ }^{24}$ According to Gregersen, we then avoid the danger that the coherent structure is purely logical or at least intralinguistic connectives without reference to the world.

RNT with its underlying constructive critical realism can benefit as an apologetic contribution when carefully navigating between the two extremes: foundationalism caught in modernistic assumptions, and coherentism without some claims of reference to reality. However, RNT as theological metaphysics has at least one assumption or starting point (although not foundationalism), which is needed for making the whole apologetic endeavor meaningful. This assumption is at the very core of theological metaphysics itself: Belief in God.

The apologetic fruitfulness of RNT is then to argue for a coherent picture of the world on a transdisciplinary level informed by insight from different fields. The underlying epistemology finds its way as a constructive critical realism, navigating between the extremes of fideism, foundationalism and relativism. To avoid apologetics ending up as a self-supporting house of cards, or as one of many competitive coherent systems without reference, the realistic claim in constructive critical realism must be acknowledged. This is the true road of doing theological metaphysics.

Further, by striving for a coherent construction, the apologetic fruitfulness can only be evaluated against other competitive coherent systems at a transdisciplinary level. At this point, Polkinghorne gives us an illustrative closing example of comparing different coherent systems:

Firstly, you can just take the brute fact of the physical world as your starting point. That's what somebody like David Hume would take. Start with the brute fact of matter as your unexplained bases. Or secondly, you can take the brute fact (if that's the word to use) of God. In other words, one can appeal to the will of an Agent, the purpose of a Creator, as the basic unexplained starting point for understanding the world. 25

These two different approaches can be described as atheism and theism, respectively. RNT, in the realm of theological metaphysics, makes sense as apologetics in terms of arguing for Christian theism as a more coherent description of reality.

The ethical dimension conveyed from constructive critical realism is my final 
stop. We need to rethink the purpose of apologetics in light of what theology is all about. In the context of apologetics, we too often deal with theology as knowledge acquisition. Miroslav Volf and Matthew Croasmun point out that, by focusing on knowledge at large, academic theology has lost track of its normative role. According to Volf and Croasmun, the "theological knowledge building" had been done at the expense of theology's ability to address normative questions. This is part of a broader academic picture:

As scientists, theologians can talk about what is and what is likely to be, but not about what should be and what we ought to hope for in the future. This, too, is a fate theology shares with humanistic disciplines, which have also traded their ability to address the "big questions" of human life for academic respectability in an intellectual environment dominated by the sciences. ${ }^{26}$

When we reduce theology to knowledge acquisitions, Volf and Croasmun continue, we are caught by a methodological constraint, which leaves little room for practical wisdom and normative judgements. Volf and Croasmun's emphasis on the normative purpose of theology corresponds with Losch's ethical concern developed in constructive critical realism. Apologetics is not so much about arguing for Christian faith as a package of knowledge acquisitions as it is about dealing with practical wisdom, and what this life is all about. Or, to use Aristotelian terms, theology is more than episteme: it is phronesis. Thus, the fruitfulness of doing apologetics is dependent on its ability to take part in the discussion of relevant normative challenges in the public sphere. Contemporary challenges include climate change, challenges on human uniqueness, and bio-technology.

\section{Closing remarks}

According to Polkinghorne, RNT is about arguing for theism as the best explanation. The locus of RNT, as this article displays, has some advantages and challenges. As an apologetic contribution, my conclusion is that RNT needs to be clarified and developed in two ways: (1) A clearer and more thoroughly understanding of the locus of RNT as theological metaphysics (2) A more profound understanding reflecting the many-layered structure of reality, which demands different methods, approaches, and involves different fields.

If RNT is about a transdisciplinary interpretation, then RNT as such assumes the existence of God. As an apologetic contribution, the realm of theological metaphysics is about developing a coherent understanding of reality, informed by insight from different fields. RNT can never be a matter of knockdown arguments, proofs or inferences from nature to God. Belief in God is a precondition for practicing RNT. The task for RNT is to argue for, and give good reasons for, belief in God by following Anselm's phrase 'faith seeking understanding'. With RNT as a transdisciplinary interpretation, we can develop a more profound and nuanced reflection of the traditional topics, such as the intelligibility of nature, the fine-tuning of nature, and beauty of nature. ${ }^{27}$

Finally, RNT should not be solely about reasoning within the context of natural science and theology. The original RNT confine itself too much to these two. One reason for this limitation is the underlying old fashion critical realism. 
We need to extend our epistemology as well. I have argued for a wider approach, where we pay attention to insight from different fields, including the humanities and social sciences. In this respect, Losch's constructive critical realism is useful. Constructive critical realism takes the postmodern situation seriously and finds its way via media foundationalism and relativism. In addition, it emphasizes the ethical dimension in our search for knowledge. The latter is most urgent for both the topics we consider as important in our apologetic endeavor today, such as climate change and the human uniqueness, as well as the credibility for how we practice apologetics in the public sphere.

\section{Notes}

1 We find many extensive contributions to a revised natural theology, although with some variations, such as Alister E. McGrath, The Open Secret: A New Vision for Natural Theology (Malden, Blackwell, 2008) and Re-imagine Nature: The Promise of a Christian Natural Theology (Hoboken, Wiley-Blackwell, 2016). In this article, I follow the concept developed by John Polkinghorne. He is considered as first-generation scientisttheologians (together with Ian G. Barbour and Arthur. E. Peacocke), and he uses explicitly the term "revised" in his natural theology. In addition, many of those who argue for a revised natural theology is in dialogue with core elements in Polkinghorne's thinking.

2 See John Polkinghorne, One World: The Interaction of Science and Theology (London: SPCK, 1986), 45ff.

3 See Knut-Willy Sæther, Traces of God (Trondheim: Tapir Academic Press, 2011), 113ff.

4 John Polkinghorne, The Faith of a Physicist: Theological Reflections of a Bottom-up Thinker (Princeton: Princeton University Press, 1994), 46.

5 John Polkinghorne, Faith, Science and Understanding (London: SPCK, 2000), 19.

6 Polkinghorne, Faith, Science and Understanding, 20.

7 Sæther, Traces of God, 121.

8 John Polkinghorne, Science and Creation: The Search for Understanding (London: SPCK, 1988), 15.

9 See Niels Henrik Gregersen, “A Contextual Coherence Theory for the Science-Theology Dialogue”, in Rethinking Theology and Science, ed. Niels Henrik Gregersen and J. Wentzel van Huyssteen (Grand Rapids: Wm. B. Eerdmans Publishing, 1998), 186.

10 See Polkinghorne Faith, Science and Understanding, 27.

11 For a discussion on critical realism, see such as Niels Henrik Gregersen, "Critical Realism and Other Realisms", in Robert John Russell ed., Fifty Years in Science and Religion: Ian G. Barbour and his Legacy, (Aldershot: Ashgate, 2004), 77-96, and Andreas Losch, "Critical Realism - A Sustainable Bridge Between Science and Religion?” Theology and Science, Vol. 8, No. 4, 2010, 393-416.

12 See such as Kees van Kooten Niekerk, "A Critical Realist Perspective on the Dialogue between Theology and Science", in Niels Henrik Gregersen and J. Wentzel van Huyssteen eds., Rethinking Theology and Science: Six Models for the Current Dialogue, (Grand Rapids: Wm. B. Eerdmans Publishing, 1998), 51-86. 13 See Ted Peters, "Science and Theology: Toward Consonance", in ed. Ted Peters Science and Theology: The New Consonance, (Boulder: Westview Press, 1998), 24.

14 See van Kooten Niekerk, "A Critical Realist Perspective on the Dialogue between Theology and Science", 74. 15 See van Kooten Niekerk, "A Critical Realist Perspective on the Dialogue between Theology and Science", 76.

16 Andreas Losch, "Our World is more than Physics: A Constructive - Critical Comment on the Current Science and Theology Debate", Theology and Science, Vol. 3, No. 3, 2005, 281.

17 Losch, "Our World is more than Physics: A Constructive - Critical Comment on the Current Science and Theology Debate", 283.

18 Losch, "Our World is more than Physics, 283.

19 Losch, "Our World is more than Physics, 285.

20 See Losch, "Our World is more than Physics, 285.

21 See Robert Audi, Epistemology: A Contemporary Introduction to the Theory of Knowledge (New York: Routledge, 2003), 194; 210.

22 In the context of the science-religion dialogue, one of many critical scholars of foundationalism is Wentzel van Huyssteen. He says foundationalism is the claim that "our beliefs can be warranted or justified by appealing to some item of knowledge that is self-evident or beyond doubt..." - J. Wentzel van Huyssteen, Essays in Postfoundationalist Theology (Grand Rapids: W. B. Eerdmans Publishing Company, 1997), 226. 23 See Van Huyssteen, Essays in Postfoundationalist Theology and Gregersen, "A Contextual Coherence Theory for the Science-Theology Dialogue", 51-86. 
24 Gregersen, “A Contextual Coherence Theory”, 193.

25 John Polkinghorne, "Religion in an Age of Science”, McNair Lecture Chapel Hill. UNC March 23, 1993.

26 Miroslav Volf and Matthew Croasmun, For the Life of the World: Theology That Makes a Difference (Brazos Press, 2019), 49.

27 On how the beauty of nature and other related experiences of nature (such as the sublime and wonder) can be explored along these lines, see Knut-Willy Sæther, "Aesthetics at the Intersection of Science and Theology", in Our Common Cosmos: Exploring the Future of Theology, Human Culture and Space Sciences, ed. Zoë Lehmann Imfeld and Andreas Losch (London: T\&T Clark, 2018), 109-124, esp. 114. 


\title{
Theofilos
}

A Nordic open access journal in Theology, Philosophy and Culture

Published by NLA University College - in partnership with Johannelund School of Theology

Available at www.theofilos.no

\section{How to formulate the fine-tuning argument for the existence of God?}

\author{
Atle Ottesen Søvik \\ Professor in Systematic Theology \\ MF Norwegian School of Theology, Religion, and Society \\ Atle.O.Sovik@mf.no
}

\begin{abstract}
This article argues that the fine-tuning argument for the existence of God should have the following characteristics:

It should be clear and logically valid.

- It should contrast the God hypothesis with a chance hypothesis as opposed to a single naturalistic universe hypothesis.

口 It should use the likelihood approach as opposed to ruling out alternatives.

I It should have a specific concept of God as a hypothesis as opposed to intention or design.

I It should have life-permittingness as opposed to fine-tuning as datum.

Different well-known formulations have different combinations of some of these characteristics, but I defend a new formulation, which has all the characteristics.
\end{abstract}

Keywords: Fine-tuning argument; formulation of the fine-tuning argument; W.L.Craig; Robin Collins; Luke Barnes

\section{Introduction}

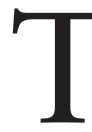

The last couple of decades has seen an increasing interest in debating arguments for and against the existence of God. Numerous debates can be found on YouTube, drawing large crowds. Among the most discussed arguments for the existence of God are cosmological arguments and design arguments. Among design arguments, most attention has been given in recent years to the fine-tuning argument for the existence of God. It is acknowledged by scholars advocating atheism as the best argument for the existence of God. ${ }^{1}$

The fine-tuning argument points to evidence indicating design. It is based on findings from physics showing that many laws of nature, forces, physical parameters and initial conditions of the universe must have very exact values in order for life to be possible. This is called finetuning, but the concept does not imply that anyone actually has fine-tuned anything, it just means that of all the possible universes, the subset that contains life is very small. For example, Roger Penrose has argued that the entropy of the early universe must have been very low, but as far as we know it could have been anything. Penrose calculates it to be finetuned to $1: 10$ raised to $10^{123} .^{2}$

Examples like this show that it is highly unlikely for life to have come 
about by chance, and so it can be used to argue that life is not a result of chance, but instead a result of design. But what is the best way to formulate such an argument for the existence of God? That is the topic for this article.

The fine-tuning argument for the existence of God has so far mainly been about fine-tuning for the existence of life. However, in a forthcoming book, Robin Collins uses fine-tuning for discoverability as an argument for the existence of God. The present article is about finetuning for the existence of life and how this can be used to formulate an argument for the existence of God, so this is what will be meant by the fine-tuning argument from now on.

Probably the two most famous defenders of the fine-tuning argument are Robin Collins and William Lane Craig. ${ }^{3}$ They formulate the argument in quite different ways. Craig offers the following formulation:

P1: Fine-tuning is due to either physical necessity, chance or design.

P2: Fine-tuning is not due to physical necessity or chance.

C: Therefore, it is due to design. ${ }^{4}$

Collins, on the other hand, formulates it this way:

(LPU=The existence of a life-permitting universe; NSU=The naturalistic single universe hypothesis; $\mathrm{T}=\mathrm{The}$ Theistic hypothesis, $\mathrm{P}=$ epistemic probability, k'=some appropriately chosen background information)

1) Given the fine-tuning evidence, LPU is very, very epistemically unlikely under NSU: that is, $\mathrm{P}\left(\right.$ LPUINSU \& $\left.\mathrm{k}^{\prime}\right)<1$, where $\mathrm{k}$ represents some appropriately chosen background information, and $<$ represents much, much less than (thus making P(LPUINSU $\& \mathrm{k}^{\prime}$ ) close to zero).

2) Given the fine-tuning evidence, LPU is not unlikely under theism: that is, $\sim \mathrm{P}\left(\right.$ LPUIT $\left.\& \mathrm{k}^{\prime}\right)<1$. 3) $T$ was advocated prior to the fine-tuning evidence (and has independent motivation).

4) Therefore, by the restricted version of the likelihood principle, LPU strongly supports T over NSU. 5

A far lesser known but very interesting formulation is offered by Norwegian philosopher Einar Duenger Bøhn, who formulates it this way:

( $\mathrm{Pr}=$ Probability, F=Fine-tuning, I=Intention, $\mathrm{C}=$ Chance)

1) $\operatorname{Pr}(\mathrm{F} \mid \mathrm{I})>\operatorname{Pr}(\mathrm{F} \mid \mathrm{C}) \quad \mathrm{L}(\mathrm{I} \mid \mathrm{F})>\mathrm{L}(\mathrm{C} \mid \mathrm{F})$

(Instance of the likelihood principle)

2) $\operatorname{Pr}(\mathrm{F} \mid \mathrm{I})>\operatorname{Pr}(\mathrm{F} \mid \mathrm{C})$

(Premise)

3) $\mathrm{L}(\mathrm{I} \mid \mathrm{F})>\mathrm{L}(\mathrm{ClF})$

$(1,2, \mathrm{MP})^{6}$

In full sentences, the argument says that if the probability of fine-tuning given intention is greater than the probability of finetuning given chance, then the likelihood of an intention given fine-tuning is greater than the likelihood of chance given finetuning. This follows from the so-called likelihood principle, which says that if hypothesis A makes us expect the data we have to a larger degree than hypothesis B, then the data counts as evidence in favour of hypothesis A.7 Since in fact the probability of fine-tuning given intention is more probable that the probability of fine-tuning given chance, it follows logically (by modus ponens) that the likeli- 
hood of an intention given fine-tuning is greater than the likelihood of chance given fine-tuning.

In this article I shall argue that the finetuning argument for the existence of God should have the following characteristics:

A) It should be clear

B) It should be logically valid

C) It should contrast the God hypothesis with a chance hypothesis as opposed to a naturalistic single-universe hypothesis, since that allows us to treat both the universe and the multiverse hypotheses when discussing the second premise.

D) It should use the likelihood approach as opposed to ruling out alternatives, since ruling out alternatives is more difficult.

E) It should have a specific concept of God as a hypothesis as opposed to just intention or design, since it is less clear what intention or design implies.

F) It should have life-permittingness as datum as opposed to fine-tuning, since fine-tuning does not follow from theism, design or intention, but life-permittingness follows from a specific God hypothesis.

Considering the formulations presented so far, William Lane Craig has A, B, C, but not D, E and F. Robin Collins has B, D, E, F, but not $\mathrm{A}$ and C. Einar Duenger Bøhn has A, B, C, D, but not E and $F$. In this article I shall suggest a new formulation which has all characteristics A-F. A and B are taken from Bøhn, C from Craig and Bøhn, D from Bøhn and Collins, and $\mathrm{E}$ and $\mathrm{F}$ from Collins.

The new formulation suggested is like this:

$\mathrm{L}=$ Life-permittingness, $\mathrm{T}=$ Theism, $\mathrm{C}=$ Chance, $\operatorname{Pr}=$ Probability

1) $\operatorname{Pr}(\mathrm{L} \mid \mathrm{T})>\operatorname{Pr}(\mathrm{L} \mid \mathrm{C}) \quad \operatorname{Pr}(\mathrm{T} \mid \mathrm{L})>\operatorname{Pr}(\mathrm{Cl} / \mathrm{L})$ (Instance of the likelihood principle)
2) $\operatorname{Pr}(\mathrm{L} \mid \mathrm{T})>\operatorname{Pr}(\mathrm{L} \mid \mathrm{C})$

(Premise)

3) $\operatorname{Pr}(\mathrm{T} \mid \mathrm{L})>\operatorname{Pr}(\mathrm{ClL})$

$(1,2, \mathrm{MP})$

In full sentences, the argument says that if the probability of life-permittingness given theism is greater than the probability of life-permittingness given a chance hypothesis, then the likelihood of theism given life-permittingness is greater than the likelihood of a chance hypothesis given life-permittingness. Since in fact the probability of life-permittingness given theism is more probable that the probability of life-permittingness given a chance hypothesis, it follows that the likelihood of theism given life-permittingness is greater than the likelihood of a chance hypothesis given life-permittingness.

When I first submitted this article to Theofilos, Luke Barnes had not yet published his article 'A Reasonable Little Question: A Formulation of the FineTuning Argument'. ${ }^{8}$ In that article, he recommends a formulation of the argument, which is quite similar to the one I suggest. His formulation is as follows:

[1] For two theories T1 and T2, in the context of background information $\mathrm{B}$, if it is true of evidence $E$ that $p(E / T 1 B)$ > p(ElT2B), then E strongly favours T1 over T2.

[2] The likelihood that a life-permitting universe exists on naturalism is vanishingly small.

[3] The likelihood that a life-permitting universe exists on theism is not vanishingly small.

[4] Thus, the existence of a life-permitting universe strongly favours theism over naturalism.

This formulation has criteria A, B, C, $\mathrm{D}$, and $\mathrm{F}$. Concerning criteria $\mathrm{A}$ and $\mathrm{B}$, it 
does have a clear and logically valid formulation. The formulation is a version of modus ponens, like I suggest, although Barnes has a bit longer and more complicated version. The criterion where we are different is criterion $\mathrm{E}$, where he uses naturalism and I use chance. Most naturalistic theories will say that life is a result of chance, and thus the difference is small. But 'naturalism' can mean many things, and by specifying 'chance', it becomes unquestionable that the probability is low.

When I read Barnes' article, I was happy to see that such a great scholar thought the argument should be formulated roughly the same way that I do. Due to reorganization in Theofilos, the publishing process took a long time, with the result that Barnes' article was published before this one. This article thereby lost some of its novelty, but I think it is worth publishing anyway. Firstly, the formulation is not precisely the same, and secondly, we offer different (although compatible) reasons for choosing this formulation. This means that the two articles support each other in showing that this should be the preferred formulation. In the rest of the article, I will discuss my formulation with the differences found in the formulations suggested by Craig, Collins and Bøhn.

What are the criteria to be used when discussing how the argument should be formulated? That, of course, depends on what one wants with the argument, but if we consider it as an argument to be used in the discussion of whether God exists, it should be formulated in a way that allows theists to make the best possible case for the existence of God while at the same time being open for the best possible refutation from atheists. In this article, I am guided by the desire to pre- sent a clear argument, well suited as an argument for God's existence while also open for the most common rejection, which is the multiverse reply.

In the rest of this article, I shall defend the claim that the argument should have the characteristics A, B, C, D, E, and F. I start at the top and work my way from A to $\mathrm{F}$.

\section{A) The argument should be clear}

This characteristic goes without saying, of course, but I mention it to point out that Robin Collins' version would benefit from being clearer. Craig and Bøhn have short and clear formulations with a clear logical structure, and I argue in this article that the argument can have all the benefits that Collins' formulation has while still being short and clear.

\section{B) The argument should be logically valid}

This characteristic is also an obvious virtue, although there can be interesting inductive arguments for the existence of God as well. It is also an advantage if the logical structure of the argument is clear, which it is in the case of Craig and Bøhn, but which it is to a lesser degree in the case of Collins. The advantage of a logically valid argument is that the discussion can be concentrated on the acceptability of the premises.

C) The argument should contrast the God hypothesis with a chance hypothesis as opposed to a naturalistic single-universe hypothesis

Craig and Bøhn discuss theism opposed to chance, whereas Collins discusses theism opposed to a naturalistic single-universe hypothesis. Collins chooses this focus since it is very clear that a life-friendly universe is not to be expected given the naturalistic single universe, whereas it is 
less clear whether a life-friendly universe is to be expected given a multiverse hypothesis. By focusing on the naturalistic single-universe hypothesis, Collins then has an easier time defending the claim that a life-friendly universe is more likely given theism than given the naturalistic single-universe hypothesis.

However, in discussions of fine-tuning as an argument for the existence of God, the multiverse alternative is usually among the first responses to come up. It would be good, then, to have an argument for the existence of God which deals with the most commonly suggested alternative. The multiverse discussion must be taken up in any case, as Collins also does when he writes about the fine-tuning argument. He even uses many of the same arguments, since he argues that both the universe and the best theories of a multiverse require fine-tuning. ${ }^{9}$

But then it would be good to deal with it in the context of the discussion of the second premise, as in the other formulations of the argument here presented.

What this means in practice is that when discussing premise two, the multiverse objection should be discussed as an objection to the premise. This is how Craig usually discusses the multiverse objection as an objection to his premise two, and how Collins also argues in practice, by responding with arguments like the Bolzmann brain argument, the argument that an infinite number of universes destroys scientific reasoning, or that the multiverse itself is fine-tuned in the most plausible theories about it. ${ }^{10}$

\section{D) The argument should have life-per- mittingness as opposed to fine-tuning as datum}

Fine-tuning can be defined in different ways. Robin Collins gives the following definition: 'The laws and values of the constants of physics, and the initial conditions of any universe with the same laws as our universe, must be set in a seemingly very precise way for the universe to support life'.11 Bøhn describes finetuning for rational life as laws, constants and initial conditions having unique numerical values taken from some very wide ranges of theoretically possible such values, and that only some few values taken from these ranges are compatible with rational life. ${ }^{12}$ Craig says that:

By 'fine-tuning' one means that small deviations from the actual values of the constants and quantities in question would render the universe life-prohibiting or, alternatively, that the range of life-permitting values is exquisitely narrow in comparison with the range of assumable values. ${ }^{13}$

In every case, the point is that the set of values needed for life to exist in our universe is very small compared to the set of possible values. This is put very clearly in the definition that Luke Barnes offers of fine-tuning: 'In the set of possible physics, the subset that permit the evolution of life is very small.'14 Fine-tuning thus says something about a life-permitting universe like ours compared with numerous other (as far as we know) non-existing universes.

This is important in the argument because it shows that it is unlikely that life arose by chance. However, it is not the case that, given an intention for life to occur or given theism, we should expect fine-tuning. An intention for life or theism makes us expect life, but it does not make us expect fine-tuning for life. The universe could just as well have been coarse-tuned for life, in which case life would also have existed in alternative 
universes different from ours. Whether life would have been probable in nonexisting universes or not seems irrelevant for an intention for life or for God. Finetuning for life thus does not follow from theism, which explains why nobody thought of suggesting that before the finetuning evidence showed up.

There may actually be a reason to expect that fine-tuning for life follows from theism if we assume a specific kind of theism or intention where the universe is also fine-tuned for discoverability. As mentioned, Robin Collins has proposed that the universe is also fine-tuned for discoverability, and then the fine-tuning for life could be a feature of the universe that the creator wanted to be discovered as a clue to its origin.

In any case, since an intention for rational life or the common versions of theism to a large degree make us expect a life-permitting universe, but to a very small degree make us expect fine-tuning, the fine-tuning argument should use lifepermittingness as the datum to be explained by theism or intention instead of using fine-tuning as the datum to be explained by theism.

One could of course argue that finetuning is best explained by design or intention via an inference to the best explanation. But I argue below that the likelihood approach is the best approach, and then one hypothesis is more probable than an alternative hypothesis if the first hypothesis, to a larger degree, makes us expect the data. Since a God hypothesis makes us expect life-permittingness but not fine-tuning, life-permittingness should be used as the datum to be explained.

Robin Collins uses life-permittingness in his formulation, but Bøhn and Craig use fine-tuning. Since Bøhn focuses on what to expect from an intention for rational life versus chance, it would be better to use life-permittingness, since it is otherwise unclear whether fine-tuning is to be expected from an intention for life. Craig also uses fine-tuning as datum instead of life-permittingness, but he does not use the likelihood approach. He looks for the explanation of fine-tuning, and uses 'design' instead of 'intention for rational life'.

However, Craig also argues that 'the implication of the design hypothesis is that there exists a Cosmic Designer who fine-tuned the initial conditions of the universe for intelligent life'15. As argued above, fine-tuning does not seem to be implied by either intention or design, since fine-tuning tells us that life would not have existed in alternative non-existing universes and there is no reason for a designer of our universe to design it in a way that would have made life impossible in alternative non-existing universes (unless the designer wanted to communicate the fact of fine-tuning). It just sounds like design implies fine-tuning because the word 'fine-tuning' suggests someone doing something, but the definition of the concept does not; it merely states a numerical relation between life-permitting universes and non-life-permitting universes.

E) The argument should have a specific concept of God as hypothesis as opposed to just intention or design

This point is related to the point above, but also differs. Above, the focus was on which datum is best to choose as the object of explanation or expectation. Here the focus is on how precise the hypothesis is, which helps us deduce more precisely what follows or is to be expected from the hypothesis.

Bøhn uses intention as his hypothesis, 
but specifies that it is an intention for rational life and that knowledge and ability to produce such life is also implied in the hypothesis. But he also specifies that it does not imply God or that the intention is good. ${ }^{16}$ This is probably to widen the range of possible agents who could have produced the universe, which increases the chance that there was some intention or other, instead of arguing that it was God. Given the problem of evil, it seems easier to argue that it was an intention that produced the universe rather than a good intention.

Bøhn discusses the objection that we do not know the mind of the intender and then cannot know more exactly what was intended. He replies that this is to confuse why the universe was intended with that the universe was intended. ${ }^{17}$ But the objection has a point in that the vaguer the description of the intention, the more difficult it is to assess what it implies or makes us expect: how much life should there be, where should it be, when should it arise, how should it be, etc.

Contrary to Bøhn, Craig and Collins have much more detailed theories of God that the fine-tuning argument is meant to support. Collins, for example, argues why God would be interested in creating a multiverse, making a discoverable universe, making an independent universe, etc. 18 That they do is natural, since Bøhn, unlike the other two, is not in the business of arguing for the existence of God. But it is an advantage, in any case, to have a more specific hypothesis in order to be better able to evaluate how probable it makes the evidence. As seen, in Bøhn's case there indeed seems to be a very vague link between intention for rational life and fine-tuning of the universe for rational life.

Even theism minimally defined as a good God is better than just design or intention since it allows us to deduce a lot more than what we can from just design or intention. Common versions of theism, which emphasize that a good and loving God would want to share of God's goods and participate in relationships, imply life-permittingness, since they entail someone with a motive and power to create life. Intention or design do not imply life-permittingness, but intention for rational life and design for rational life do imply life-permittingness. None of the three imply fine-tuning. But the more detailed the theism is fleshed out the better, because it gives us more opportunity to consider the coherence of the claims made.

F) The argument should use the likelihood approach as opposed to ruling out alternatives

Collins and Bøhn use the likelihood approach while Craig rules out alternatives. I will consider Craig's approach first. Craig argues against physical necessity and chance as explanations of fine-tuning and concludes that design is the explanation. Of the three alternatives, he says that they seem to exhaust the alternatives. ${ }^{19}$ Is that right?

It seems to me that a plausible alternative to physical necessity is a physical explanation that explains the different values and shows that we are wrong today in treating all possible universes as equally probable. It would not need to be a physical necessity, but could be a contingent physical explanation. Yet it would not be the chance alternative either, because the chance alternative says that fine-tuning is due to chance, but this alternative would say that fine-tuning is merely apparent because there is not a large range of equally possible values. 
It is not at all clear to me that the alternatives rule each other out, either. If we discovered that a fine-tuned universe was necessary, would it not be surprising that such a universe was physically necessary as opposed to another kind of universe? Could not the creator have made a universe where it was physically necessary for life to arise, and this be used as an argument for the existence of God? It seems better to use metaphysical necessity or logical necessity as alternatives to God, although one could probably let those metaphysical or logical necessities be part of God as well.

I will not open the big discussion on how to define different kinds of necessity, but rather use these questions raised to show that the first premise in Craig's formulation is not so obvious. I find the likelihood approach of Collins and Bøhn better suited to avoid such criticism because they can consider the relation between hypothesis and evidence in a logically valid argument without being concerned that they have exhausted all alternatives.

Craig could argue against Bøhn and Collins that they do not exhaust the alternatives but just argue in favour of one hypothesis over another. However, arguing in favour of theism over chance (including the multiverse hypothesis) is to contrast the two hypotheses that most people find to be the two most plausible options, and it is a good strategy to discuss the best alternatives.

An objection against Collins and Bøhn could be that likelihood and conditional epistemic probability are vague concepts riddled with problems. Bøhn in fact says that he finds conditional epistemic probability to be indefinable, ${ }^{20}$ but both he and Collins refer to the fact that it is widely used in science and everyday life. Collins gives a quite-detailed account of his understanding of conditional epistemic probability, leaning on Plantinga's understanding of conditional epistemic probability and discussing some objections. The discussion of how to understand probability is too big to resolve here, but given that it is so widely used, it seems acceptable to use it also in this case.

\section{A few comments on objections to the fine-} tuning argument

There are many objections one could raise to the fine-tuning argument, but these cannot be discussed here for reasons of space. Nevertheless, I will end with some comments on the objections that can be raised.

Luke Barnes does a very good job in showing how formulating the argument this way helps to avoid many of the common objections. ${ }^{21}$ Robin Collins also covers very well a wide range of objections. ${ }^{22}$ The most common objection to the fine-tuning argument is the multiverse response, which says that if there are numerous different universes, it is likely that some (like ours) should be life-permitting. Collins covers the common objections to the multiverse response, like the Boltzmann brain objection, the objection that in the best multiverse theories, the multiverse is itself fine-tuned, and that the multiverse hypothesis (presupposing an infinite number of universes) undermines rationality.

In a future article, I hope to develop a new response to the multiverse objection. My argument will be that either there is just one universe, in which case it is most likely designed by God, or there is a multiverse generated by some multiverse generator with the capacity for actualizing infinitely many possibilities. In the latter case, I will argue that it is highly likely that one of the possibilities the multiverse 
generator has actualized is a mind connected to the generator itself. But if the multiverse generator has a mind, one could argue that it deserves to be called God. The conclusion is then that regardless of whether one assumes a universe or a multiverse, one should assume that it is created by a source with a mind.

Given that I do not think that the multiverse is a good objection to the finetuning argument, what is the best objection? I think that the best objection is that we have very little knowledge about why the parameters of the universe are as they are, which again means that our basis for establishing their probability is very thin. The future may offer a naturalistic explanation to fine-tuning, but of course, the future may also do the opposite. What matters is what conclusion is best justified today by the fine-tuning argument, and then I think theism is clearly the best-justified conclusion.

\section{Conclusion}

There is a way of combining the virtues I have argued for in this article into a new formulation of the fine-tuning argument for the existence of God. It leans quite heavily on the formulation offered by Einar Duenger Bøhn, but importantly replaces fine-tuning with life-permittingness and intention with God. The formulation is as follows:
$\mathrm{L}=$ Life-permittingness, $\mathrm{T}=$ Theism, $\mathrm{C}=$ Chance, $\operatorname{Pr}=$ Probability 1) $\operatorname{Pr}(\mathrm{L} \mid \mathrm{T})>\operatorname{Pr}(\mathrm{L} \mid \mathrm{C}) \quad \operatorname{Pr}(\mathrm{T} \mid \mathrm{L})>\operatorname{Pr}(\mathrm{C} \mid \mathrm{L})$ (Instance of the likelihood principle)

2) $\operatorname{Pr}(\mathrm{L} / \mathrm{T})>\operatorname{Pr}(\mathrm{L} / \mathrm{C})$

(Premise)

3) $\operatorname{Pr}(\mathrm{T} \mid \mathrm{L})>\operatorname{Pr}(\mathrm{Cl} \mathrm{L})$ $(1,2, \mathrm{MP})$

In full sentences, the argument says that if the probability of life-permittingness given theism is greater than the probability of life-permittingness given a chance hypothesis, then the likelihood of theism given life-permittingness is greater than the likelihood of a chance hypothesis given life-permittingness. Since in fact the probability of life-permittingness given theism is more probable than the probability of life-permittingness given a chance hypothesis, it follows that the likelihood of theism given life-permittingness is greater than the likelihood of a chance hypothesis given life-permittingness.

This way of formulating the argument is a bit tedious and clumsy, but shows explicitly that it is a deductive argument. The main idea is to use the terms theism, chance and life-permittingness, and say that since life-permittingness is more probable given theism than chance, life-permittingness favours theism over chance in this respect.

\section{Notes}

1 This is my experience from having participated in several public debates on the existence of God, and also expressed in for example Sean M. Carroll, The Big Picture: On the Origins of Life, Meaning, and the Universe Itself (New York: Dutton, 2016), 303.

2 Roger Penrose, The Road to Reality: A Complete Guide to the Laws of the Universe (London: Jonathan Cape, 2004), 762-65.

3 Robin Collins, 'The Teleological Argument: An Exploration of the Fine-Tuning of the Universe,' in The Blackwell Companion to Natural Theology, ed. William Lane Craig and James Porter Moreland (Malden, MA: Wiley-Blackwell, 2009) ; William Lane Craig, Reasonable Faith: Christian Truth and Apologetics, 3rd ed. (Wheaton, IL: Crossway Books, 2008).

4 Craig, 161.

5 Collins, 207. The formulation is similar to the approach chosen by Richard Swinburne, in Richard Swinburne, The Existence of God, 2nd ed. (Oxford: Clarendon Press, 2004), 184. 
${ }^{6}$ Einar Duenger Bøhn, 'Why This Universe?,' in Talking Seriously About God, ed. Asle Eikrem and Atle Ottesen Søvik, Nordic Studies in Theology (Zürich: LIT Verlag, 2016).

7 Collins, 205. I follow Collins in using a restricted version of the likelihood principle, which adds that the hypothesis must not be ad-hoc (ibid., 202, 06.).

${ }^{8}$ Luke A. Barnes, 'A Reasonable Little Question: A Formulation of the Fine-Tuning Argument,' Ergo: An Open Access Journal of Philosophy 6 (2019): 1225.

9 Collins, 262-69.

10 Ibid., 256-72.

11 Ibid., 204.

12 Bøhn, 130.

13 Craig, 158.

14 Luke Barnes, 'The Fine-Tuning of the Universe for Intelligent Life,' Publications of the Astronomical Society of Australia 29, no. 4 (2012): 529.

15 James Porter Moreland and William Lane Craig, Philosophical Foundations for a Christian Worldview (Downers Grove, IL: InterVarsity Press, 2003), 489.

16 Bøhn, 130.

17 Ibid., 134.

18 Robin Collins, 'Home Page of Robin Collins,' http://home.messiah.edu/ rcollins/.

19 Craig, 161.

20 Bøhn, 134.

21 Barnes, 1241-51.

22 Collins, 'The Teleological Argument: An Exploration of the Fine-Tuning of the Universe.' 


\title{
Theofilos
}

\section{Intelligent Design and Natural Theology}

\author{
Steinar Thorvaldsen \\ Professor of Information Science, Department of Education \\ The Arctic University of Norway, Norway \\ steinar.thorvaldsen@uit.no
}

\begin{abstract}
Natural Theology is an attempt to provide arguments for the existence of God based on reason and ordinary experience of nature. It became quite popular with both orthodox Christians and Deists between about 1650 and 1850, inspiring much of the scientific fieldwork done during that period. However, Darwin's theory of evolution brought about a temporary decline of this Christian apologetic tradition.

Intelligent Design is a relatively new scientific research program that investigates the effects of intelligent sources, and challenges basic parts of contemporary Darwinism. Fred Hoyle first issued the ideas of Intelligent Design in modern times when he discovered the unique energy level of the carbon atom in the 1950s. On Copernicus's 500th birthday in 1973, Brandon Carter presented the discovery that the fundamental constants of physics are fine-tuned to precise values for life permittance. In the 1990s, Michael Behe and others presented arguments for Intelligent Design in molecular biology, and irreducibly complex biochemical machines in living cells.

In this paper, we briefly present Intelligent Design and discuss its possible application within a revitalized version of Natural Theology. The paper is mainly written from a scientific perspective.
\end{abstract}

Keywords: Fine-tuning, Design, Darwinism, Molecular machines, Complexity

\section{Introduction}

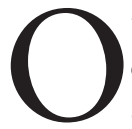

ur subject is part of a wider discussion about the relationship of science to religion. In most parts of the world, both science and religion have substantial influence on people's lives and ways of thinking. The impact of science and technology is even so penetrating that we hardly notice it.

According to Ian Barbour, there are four ways of relating science and religion: ${ }^{1}$

\section{Conflict}

2. Independence

3. Interaction

4. Integration

These models interpret the relationship quite differently, but none of them regards religion as something irrelevant for society. Barbour's work is an attempt to revisit the interface between science and religion, and constitutes a conceptual investigation of the differences, meeting points, and parallels between them. $\mathrm{He}$ 
aims to move beyond conflict and independence to greater dialogue, and the interaction model provides one way for making that move. There are a number of arguments for this. First, human experience does not divide itself into discrete experiences, since reality is handled as a whole. Second, for Christians, God is the creator of all that is, and if God is the source of the whole of the universe, then Christians should seek explanations that do not separate religious faith from the natural world. Thirdly, the need for a response to the environmental crisis demands a strong theology of nature, grounded in biblical faith commitments and engaged with scientific knowledge of the world. Given those demands, interaction between science and religion is a much-needed contribution to an educated discourse.

Integration is the 4th model for thinking about relating science and religion. In addition to interaction, integration also focuses on the relationships between theological doctrines and particular scientific theories. According to Barbour, the classic Natural theology and Barbour's own Theology of nature are two examples of the integration between science and religion. Whereas the traditional Natural theology mainly looks to design in nature as supportive of God's existence, the Theology of nature has a broader scope and develops theories and doctrines that are heavily informed by theories of science. ${ }^{2}$ Such an approach is more radical, and may include revisions of some traditional doctrines on creation, providence or human nature, in the light of current science. Barbour has built his 'Theology of nature,' on Darwinian theory and the naturalistic philosophy that undergirds it. $\mathrm{He}$ presupposes that the Darwinian mechanism is the means by which biological complexity has emerged within nature.

A large amount of academic literature on these topics has appeared since the 1970s. However, it is difficult to evaluate how successful it has been. The general public still seems convinced that science and religion are in conflict with each other. This is largely the result of quite aggressive atheists such as Richard Dawkins and others, ${ }^{3}$ whose works are translated worldwide and have influenced public opinion. Even academics often limit their knowledge to these sources.

In addition, theological institutions only sparsely focus on the interaction between science and religion. Especially in systematic theology, discussions concerning the scientific worldview and the possibility of divine action are often more or less ignored. If theologians are not taking the dialogue seriously, who is?

In this paper, we first introduce Natural Theology and Intelligent Design. A more extensive elaboration and discussion of the scientific arguments for detecting design may be found in our recent statistical paper 'Using statistical methods to model the fine-tuning of molecular machines and systems.' ${ }^{4}$ In the second part of the present paper, we discuss the application of the design arguments within a revitalized version of Natural Theology.

\section{Natural Theology (NT)}

In the first period in the history of modern science, the declaration of purposiveness in the observed nature was not regarded as an embarrassment, but rather an accepted fact. ${ }^{5}$ Pioneers like Johannes Kepler, Galileo Galilei and Isaac Newton were all motivated by, and promoted their innovative research as, 'reading the book of nature'. ${ }^{6}$ Modern science grew 
up in Europe around the beginning of the 17 th century, and Christianity had the function of being some of the soil from which it grew.

In spite of some unfortunate tension, Christian theology can still claim to have helped birth the basic beliefs and impulses that gave rise to modern empirical science. A number of historians and sociologists have come to view modern science itself as the historical product of Christianity. It is hard to get much further from the conflict thesis than this. ${ }^{7}$ There exists a profound causal connection between Christianity and early modern science. This is an important historical fact for Christian apologetics. ${ }^{8}$

Natural theology was in this period quite important for the whole science and religion dialogue. The phrase 'natural theology' can have several meanings that in general substantiate an intellectual resonance between the Christian worldview and the natural world. Thus, the world that we see and experience around us is believed to have a deeper transcendence, which lies beyond it, but in some ways are embedded in the world that we observe.

In the year 1802 William Paley published his famous book Natural Theology: or, Evidences of the Existence and Attributes of the Deity; Collected from the Appearances of Nature. ${ }^{9}$ The main message of this book was that all nature speaks of the Designer behind it. Paley's argument is constructed around a series of examples, including finding a watch, comparing the eye to a telescope, and the existence of finely adapted mechanical structures in animals: from the intricacy of the bird's wing to the complexity of the eye, since living structures are far beyond the power of physical processes operating by natural laws, they must be the wise contrivance of a Creator. In consequence, the existence of the structured world and life around us, proved the existence of a designer or God behind them.

The theological interpretation of Payley's thesis became known as Natural theology and was widely applied in theological circles almost everywhere where thinking Christianity existed. The book was used for many years as a textbook in British universities as a basis for examination for undergraduates. Natural Theology became quite popular with both orthodox Christians and Deists. It prospered greatly as an apologetic tool, particularly in England, between about 1650 and 1850 , inspiring much of the fieldwork done in biology during that period. Collecting butterflies, beetles, flowers and ferns etc., also became a popular outdoor hobby, all with a sense of attaining a closer understanding of nature's master Designer.

Within German biology, a coherent body of theory based on a teleological approach was also worked out. The history of pre-Darwinian German biology in the nineteenth century is acknowledged as very active in the growth of empirical knowledge, which includes the beginning of modern embryology, paleontology, physiology and organic chemistry. One main impetus for the development of biological thought in Germany came from an idealistic philosophy of nature known as romantische Naturphilosophie. ${ }^{10}$ Here the central issue was the problem of causality in biology, and Timothy Lenoir labels this approach a 'theory of limited evolution'. 11 The romantic natural philosophy embraced at least the aesthetic dimension of natural theology. ${ }^{12}$

The problem with the arguments in Natural Theology is, of course, that they can be turned head around. Thus for 
every instance where the natural theologian finds reason to sing God's praises, the natural anti-theologian finds reason to lament nature's cruelty. Darwin, for instance, thought there was 'too much misery in the world' to find support in Natural Theology:

I cannot persuade myself that a beneficent and omnipotent God would have designedly created the Ichneumonidae [a parasitoid wasp] with the express intention of their feeding within the living bodies of Caterpillars [a larvae], or that a cat should play with mice. ${ }^{13}$

Other examples he pointed to included 'ants making slaves' and 'the young cuckoo ejecting its foster-brother.' We may note that Darwin's intellectual struggles with the problem of evil were plainly $p h i$ losophical and theological in nature they had not proceeded from his science. However, he did not give the problems any further elaboration. Darwin apparently understood that the ultimate framework for a basic interpretation of nature could not be scientific, but was philosophical and rooted in an individual's conception of the relationship between the natural world and religion. Hence, the presence of natural suffering accorded well with his theory of natural selection, rather than with purpose and design in the optimistic setting of contemporary Victorian theology of a world in gentle harmony.

With Darwin, a grand unifying science of life was set forth by the principle of natural selection. The new Darwinian Theory reduced some of the conceptual difficulties to scientific progress in biology, like vitalism and some speculative teleological thinking. On the other hand, the theologians could no longer base their teaching confidently on the thesis that
'The havens declares the glory of God, and the firmament shows his handiwork'. ${ }^{14}$

Darwin changed the direction of the discussions through his explanation of biology as a product of natural processes. This mechanistic point of view carries with it the naturalistic aims of modern science. Natural Theology changed focus to natural philosophy, later this was replaced by natural history. Because they held to a naturalistic definition of science, Darwinian explanations seemed more sensible to most scientists. Payley's theory was more or less destroyed and substituted by the new Darwinian 'plots and stories'15. Eventually, Darwin's theory brought about the decline of the Christian apologetic tradition in science, in spite of some academic attempts to rescue the project of Natural Theology. ${ }^{16}$ Lynn Barber ${ }^{17}$ documents very well the close relationship between the declining public interest in natural philosophy and the corresponding ascendancy of the theory of evolution.

\section{Intelligent Design (ID)}

The fundamental idea behind ID is that events, objects, and structures in the world can exhibit features that reliably signal the effects of intelligence. Disciplines as diverse as semiotics, archeology, cryptography, forensic science, and the search for extraterrestrial intelligence thus all fall within ID. ID begins with features of the world that are inherently resistant to naturalistic explanation given the available natural resources - not merely features of the world that for now lack a known natural-cause explanation, but rather for which natural causes are in principle incapable of providing an explanation. Next, ID notes that in our normal 
experience, when objects whose causal story we know show such features, then an intelligence was definitively involved in the object's causal history.

The very term intelligence comes from the Latin words 'inter' (a preposition denoting 'between') and 'lego' (a verb denoting to 'choose' or 'select'). Hence, strictly speaking intelligence refers to the power of discerning and the ability to select. Yet unlike natural selection, which operates without intentions or goals, typically when we think of an intelligence as choosing or selecting, it is with a goal or purpose in mind. We could therefore define intelligence as the capacity for rational or purposive choice.

The textbook definition of ID reads: 'The study of patterns in nature that are best explained as the product of intelligence'. ${ }^{18}$ Intelligent means nothing more than being the result of an intelligent source, and does not presume optimal design. 'Intelligent' in 'intelligent design' simply refers to intelligent sources, irrespective of skill, mastery, or cleverness.

For Del Ratzsch, design needs another concept, namely counterflow, which 'refers to things running contrary to what, in the relevant sense, would (or might) have occurred had nature operated freely.' 19 Furthermore, 'an artifact is anything embodying counterflow.'20 That does not mean, of course, that any violation of natural law (counterflow) can be defined as design, but we typically recognize artifactuality and designedness through recognizing indications of counterflow in results, processes or initial conditions: 'we recognize such counterflow against the background of and in contrast with our understanding of the normal flows of nature.'21

ID has gained a good deal of interest and influence in recent years, mainly in the USA, by both creating public attention and triggering vigorous discussions in the intellectual and scientific world. The term is often considered controversial, and many prefer to use the term design alone, since usually we think of design as the result of intelligence, and hence the adjective is redundant. However, Intelligent Design is the original historic term that Professor William Whewell at Trinity College, Cambridge, coined in a scientific context as far back as in 1833.22 The term was applied by Darwin, and also by Hoyle $^{23}$ when he reintroduced the idea within modern science in his 1982 Omni Lecture at the Royal Institution, London. In this paper we use both the short and long notion.

\section{Quantum physics}

The famous astronomer Sir Fred Hoyle did the first basic ID-discovery of our time as early as in the 1950 s, ${ }^{24}$ when he predicted that the carbon core has a unique state with a specific energy level which is precisely adapted to the basic fusion process for carbon creation. This result was one of the most important breakthroughs in modern astrophysics, and the so-called Hoyle state of the carbon atom has become a cornerstone for state-of- the-art nuclear theory. He described his discovery like this:
Would you not say to yourself, 'Some super-calculating intellect must have designed the properties of the carbon atom, otherwise the chance of my finding such an atom through the blind forces of nature would be utterly minuscule.'... The numbers one calculates from the facts seem to me to so overwhel- ming as to put this conclusion almost beyond question. ${ }^{25}$

All known life in this universe is based on the element carbon, which is formed in 
the nuclear processes that occurred as previous stars ended their lives. The calculations he made in time revealed a finetuning of the universe. Hoyle had started his research career as an atheist, but this scientific discovery shook his atheism fundamentally. ${ }^{26}$

\section{General physics}

To our surprise, it turns out that many of the parameters necessary for life to exist in our universe must fall within very narrow margins, or the universe would either not exist or not be able to support life. The astrophysicist Brandon Carter was the first to name and employ the term Anthropic Principle in his important contribution to the 1973 conference in Poland honoring Copernicus's 500th birthday. He had worked with a kind of counterfactual analysis of cosmology by asking the question: Suppose the laws of physics had been a bit different from what they actually are, what would the consequences be?27 In his lecture, Carter derived the Anthropic Principle in reaction to the old Copernican Principle, which states that humans do not occupy a privileged position in the universe. As Carter said on Copernicus's birthday:

Although our situation is not necessarily central, it is inevitably privileged to some extent. 28

The chances that the universe should be life permitting are so infinitesimal as to be incomprehensible and incalculable. Many studies have been accomplished since then. Luke Barnes published a good review paper on the fine-tuning of the universe in $2012^{29}$ and Lewis \& Barnes wrote an up-to-date book in 2016.30

It is hard to give a definitive answer to the number of fine tuning parameters. Based on the items discussed in Barrow and Tiplers' classic book ${ }^{31}$ there are about 100, and The Royal Astronomer Martin Rees lists six dimensionless constants that give overall fine-tuning to the universe. ${ }^{32}$ The finely tuned universe is like a panel that controls the parameters of the universe with about 100 knobs that can be set to certain values. If you turn any knob just a little to the right or to the left, the result is either a universe that is inhospitable to life or no universe at all. If the Big Bang had been just slightly stronger or weaker, matter would not have condensed, and life never would have existed. The odds against our universe developing were 'enormous' - and yet here we are, a point redolent with religious implications, as expressed by Brian Schmidt at the Australian National University:

Like a Bach fugue, the Universe has a beautiful elegance about it, governed by laws whose mathematical precision is meted out to the metronome of time. These equations of physics are finely balanced, with the constants of nature that underpin the equations tuned to values that allows our remarkable Universe to exist in a form where we, humanity, can study it. A slight change to these constants, and poof, in a puff of gedanken experimentation, we have a cosmos where atoms cease to be, or where planets are unable to form. We seem to truly be fortunate to be part of Our Universe. 33

What Brian Schmidt refers to as a 'gedanken experiment' (thought experiment), is often called 'multiuniverses', i.e. an enormous supply of universes and each one a little different. This hypothesis is not backed up with any empirical support, and Nobel laurate in physics Charles Townes rejects this speculative idea as a 'pretty fantastic postulate'. Instead, Townes thinks this 'fine-tuning' of the universe 
points to intelligent design:

Intelligent design, as one sees it from a scientific point of view, seems to be quite real. This is a very special universe: it's remarkable that it came out just this way. 34

One nice recent study shows that if the mass of the quarks that make up protons and neutrons were changed by just a few percent, then the process that makes carbon as stars die would be altered in such a way that there would not be sufficient carbon in the universe for life. The masses of the lightest sub-atomic quarks have the precise value that is required for carbon to form and for life to exist. 35 The fact that the conditions for life fall into such a narrow range, plus the many incredible initial conditions and constants in physics that give rise to the needed building blocks of life, constitute the fine-tuning of the bio-friendly universe. Fig. 1 is a simple illustration.

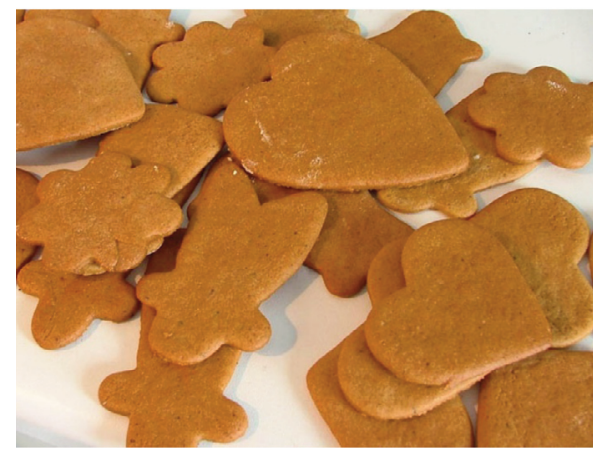

Figure 1: Illustration of fine-tuning suggested by a schoolchild: Bake several batches of pepper cookies, each time varying one ingredient, oven-baking temperature or time up or down by a minor amount. Call it a 'Cookie Universe' and successfully demonstrated the fine-tuning principle by the taste of the cookies. From www.arn.org

\section{Molecular machines}

One of the surprising discoveries of modern biology has been that the cell operates in a manner similar to modern technology, while biological information is organized similar to plain text. Words and terms like sequence code, and information, proofreading, and machine have proven very useful in describing and understanding molecular biology. ${ }^{36}$ Living forms exhibit structures and functions that can best be understood as nano-level engineering. In 1998 Bruce Alberts, president of the National Academy of Sciences, published an important paper preparing the next generation of molecular biologists: 'The Cell as a Collection of Protein Machines'. ${ }^{37}$ In the same manner, the ID research program also highlights the designed structure of life in nature against Darwinian natural selection and gradualism, and in the 1990s, Michael Behe and others argued for ID in molecular biology and irreducibly complex biochemical machines in living cells. ${ }^{38}$ Some parts of complex designed objects are exceedingly important and useful and do affect the function of their mechanism. The intelligence of the designed product and its smart processes can be outlined through the vital and functional parts of living organisms. In 'Darwin's Black Box' Behe exemplifies the systems that he called irreducible complexity configured as a remarkable teamwork of several interacting proteins.

However, Behe does not ignore the role of the laws of nature. Biology allows for changes and evolutionary modifications. Evolution is there, ID is there, and they are consistent with one-another. The laws of nature can organize matter and force it to change. Behe's point is that there are some, 'irreducibly complex' systems that are very unlikely to be produced by the laws of nature, and this is sufficient for his argument to work: 
If a biological structure can be explained in terms of those natural laws [reproduction, mutation and natural selection] then we cannot conclude that it was [intelligently] designed... however, I have shown why many biochemical systems cannot be built up by natural selection working on mutations: no direct, gradual route exist to these irreducible complex systems, and the laws of chemistry work strongly against the undirected development of the biochemical systems that make molecules such as AMP. 3940

Then, even if the natural laws work against the development of these 'irreducible complexities', they exist. Putting 'intelligent' in front of 'design' ensures that the design he is talking about is not merely apparent but actual; actual in the sense that the design is a strong synergy in principle irreducible to natural causes. These structures are biological examples of nano-engineering that surpass anything human engineers have created. Fig. 2 shows a high-resolution image.

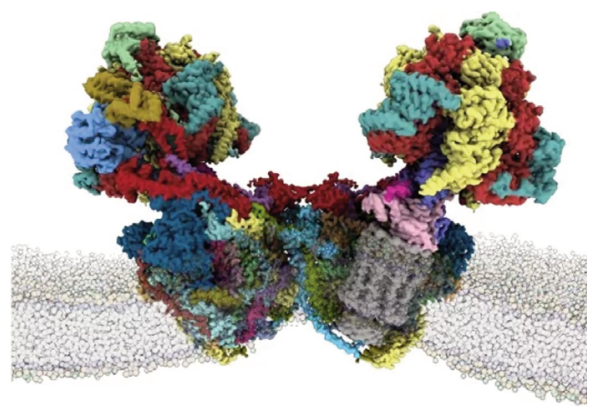

Figure 2: Researchers at Stockholm University solved the structure of a mitochondrial ATP synthase. ATP synthase is a molecular machine that catalyzes conversion of chemical energy of cells. The high resolution allowed identification of 29 different protein subunits. Credit: A. Müblpeip.

From www.scilifelab.se

\section{Proteins}

The basic building blocks of life are proteins, long chain-like molecules consisting of varied combinations of 20 different amino acids. Complex biochemical machines are usually composed of many proteins, each folded together and configured in a unique 3D structure dependent upon the exact sequence of the amino acids within the chain. Proteins employ a wide variety of folds to perform their biological function, and each protein has a highly specified shape with some minor variations. An important question is to obtain an estimate of the overall prevalence of sequences adopting functional folds, i.e. the right folded structure, with the correct dynamics and a precise active site for its specific function. Douglas Axe worked on this question at the famous Medical Research Council Centre in Cambridge. The experiments he performed showed a prevalence between 1 in $10^{50}$ to 1 in $10^{74}$ of signature-consistent sequences forming a working domainsized fold of 150 amino acids. ${ }^{41}$ Hence, functional proteins require highly extraordinary sequences. Though proteins tolerate a range of possible amino acids at some positions in the sequence, a random process producing amino-acid chains of this length would stumble onto a functional protein only about one in every $10^{50}$ to $10^{74}$ attempts. This empirical result is analog to our previous ID inferences from fine-tuned physics.

In his recent book, Undeniable, Axe also elaborates on the massive improbabilities of anything like functional proteins arising by natural selection. The search space turns out to be too impossibly vast for blind selection to have even a slight chance of success. The contrasting view is innovations based on ingenuity, 
cleverness and intelligence. An element of this is what Axe calls 'functional coherence', which always involves hierarchical planning, hence is a product of design. He concludes: 'Functional coherence makes accidental invention fantastically improbable and therefore physically impossible.' ${ }^{42}$ Fig. 3 shows an example of a functional protein.

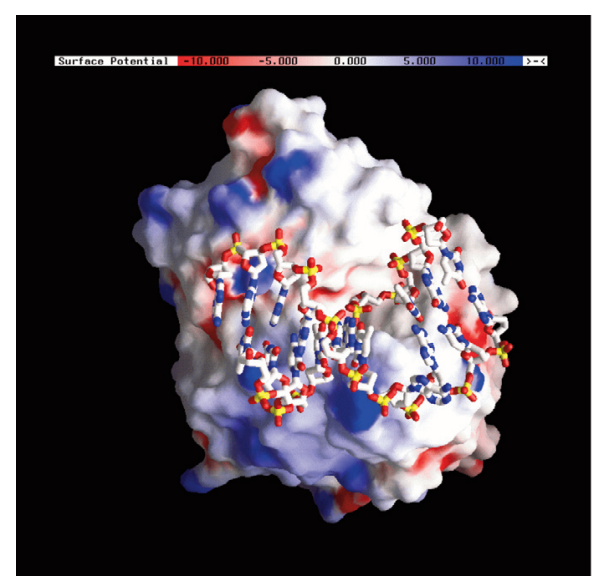

Figure 3: The enzyme Uracil-DNA-glycosylase (UNG) is a fold of 233 amino acids and repairs errors in DNA. UNG is an important intracellular, monomeric enzyme that recognizes and removes errors occurring when DNA is copied. The figure shows how DNA is attached to the enzyme.

\section{Measuring design}

Science is to a large extend devoted to measuring quantities, and much effort has been devoted to detecting design and finding a general information measure. Del Ratzsch ${ }^{43}$ has expressed doubt on the prospects of recognizing designedness through secondary marks, because in the context of identifiable artifacts, that artifactuality by itself automatically establishes some of the crucial conditions for design.

In order to infer design, an object must be both complex and specified. The latest version of an information measure published by Dembski et al. is named Algorithmic Specified Complexity (ASC). ${ }^{44}$ ASC incorporates both Shannon and Kolmogorov complexity measures, and measures the degree to which an event is improbable and follows a pattern. Kolmogorov complexity is related to compression of data (and hence patterns), but suffers from the property of being unknowable as it has no general method to compute it. However, it is possible to give upper bounds for the Kolmogorov complexity, and consequently ASC can be bounded without being computed exactly. ASC is based on context and is measured in bits. The authors have applied this promising method to natural language, random noise, folding proteins, images etc. 45 This is an area of research, and recently George Montanez published a general method of detecting design that incorporates randomness and specificity, and unifies many previous attempts. ${ }^{46}$

\section{ID's relation to NT}

ID argues that the effect of a design inference can be deduced within the limits of explanatory options, not from identifying an external cause. We may detect that our house has been cleaned, without knowing who did it. To identify an ultimate cause we need additional details, but ID is not primarily in the business of telling causal stories. Dembski argues for the distinction like this: ${ }^{47}$

Although a design inference is often the occasion for inferring an intelligent agent, as a pattern of inference the design inference is not tied to any doctrine of intelligent agency. The design inference focuses on features of any event that bar it from being attributed to chance, not on the causal story underlying 
the event. To be sure there is a connection between the design inference and intelligent agency. This connection, however, is not part of the logical structure of the design inference. Certain events are properly attributed to chance, certain events are not. The design inference marks the difference, yet without prejudging the underlying causal story.

Hence, Dembski does not commit the category mistake of failing to distinguish causal agency from the underlying mechanism. There are natural laws and there are ID, yet none of these is enough to conclude that there is a lawgiver or designer God. Inferences to design should not require that we have a candidate for the role of a designer. That will be an additional interpretation that has to be done in a wider context.

Clearly, ID provides ready meals for NT, and many ID-scientists are Christians and believe on independent theological grounds in a designer God. However, some also avoid making any ontological commitments about a designer, and are perfectly content investigating design in nature. 48 ID may for the time being be operated mainly by Christians. But Christians do not own it - it is not even owned by theists. ID is not a form of NT. The aims are substantially different.

The designer that eventually emerges from ID-theory is an intelligence capable of originating the complexity and specificity that we find throughout the universe, especially in biological systems. The designer of ID is not the God of any particular philosophical reflection or the God of any particular religion, but merely an intelligent source that is capable of initiating certain features of the natural world. Persons with theological commitments can co-opt this designer and identify this designer with the object of their faith. However, this inference is strictly free as far as the actual science of ID is concerned. The point is to see if design offers fresh scientific insights, not to establish the existence of the designer. ID therefore makes an epistemological rather than ontological point.

\section{Discussion}

We have presented four central observations from contemporary science; two from 'hardware' physics, and two from 'software' biology. The framework of ID depends on the concept of probability theory, information, computer science, molecular biology, and the philosophy of science. Exponents of ID claim that it is a valid scientific field because it builds on the same prima causa premise used in all other areas of science. They observe information systems in the cells of living organisms and question the source of that information. The main issue that motivates ID is a concern for good science, and ID aims to adhere to the same standards of rational investigation as other scientific and philosophical enterprises, and is subject to the same methods of evaluation and critique. We will discuss the ID-arguments above in this context. Can they be formulated as rigorous scientific arguments?

William Dembski has noted that the fine-tuning argument for our universe is not a strict statistical argument, since it involves features that need to be in place before the universe can be said to exist and operate. ${ }^{49}$ And there is no way of assigning a probability distribution as reference associated with the universe in that early stage. Probabilities for the initial formation of the universe are by their nature independent of known processes operating in our present universe. 
Dembski regards the fine-tuning argument as suggestive, as pointers to underlying ID. We may describe this statistical inference as abductive reasoning or inference to the best explanation. ${ }^{50}$ An explanation is a story about an event that has occurred, and explanatory inferences play a central role in both ordinary life and scientific thinking. Computer science, expert systems and artificial intelligence research frequently employs it. Abduction is the procedure of choosing the hypothesis or theory that best explains the available data. This process yields a plausible conclusion but does not positively verify it. The plausible result is relatively likely to be true, compared to competing hypotheses, given our background knowledge. In the case of fine-tuning of our cosmos, ID is considered to be a better explanation than a set of multi-universes that lacks any empirical evidence. ${ }^{51}$

The constants of nature are universal properties wherever matter exists, and the unique resonance state of the carbon atom discovered by Hoyle is a consequence of the fine-tuned properties of the 12 particles in the atomic core. Science is still working on details of this very complicated 12-body problem, and by utilizing powerful supercomputers, a team of scientists have calculated the properties of the Hoyle state from the fundamental constants and forces of nature. ${ }^{52}$ The process of production runs by the laws of nuclear physics, and the carbon product displays its additional fine-tuning property at the atomic level.

A Behe-system of irreducible complexity is composed of several non-arbitrarily, well-matched, interacting modules that contribute to a basic function, wherein the removal of any one of the modules causes the system to effectively cease functioning. The system cannot be sub- stantially simplified and yet preserve function. Such systems pose a serious challenge to a Darwinian account of evolution, since irreducibly complex systems have no direct series of selectable intermediates. This logic has been severely criticized, and extensive arguments have been written about whether or not Darwinian evolution can plausibly explain irreducibly complex systems. ${ }^{53}$

Irreducible complexity does not mean that irreducibly complex systems are logically impossible to evolve. One cannot definitively rule out the possibility of an indirect, circuitous route. As the complexity of an interacting system increases, however, the likelihood of such an indirect route drops quickly. Hence, Darwinian explanations of irreducibly complex systems are improbable.

Ultimately, this is a question that has to be studied experimentally and by computer simulations. The flagellum that bacteria use to swim, and the blood-clotting cascade, are two well-studied cases. Both consist of dozens of protein parts, and despite more than twenty years of effort, no Darwinian pathway has been found. ${ }^{54}$ In addition, computer models have not falsified Behe's concept of irreducible complexity. ${ }^{55}$ William Dembski has suggested a statistical model, inspired by the Drake equation from astrobiology, that may be useful to analyze probabilities of Behe-systems, and he found very low values. ${ }^{56}$

The paper by Douglas Axe we referred to earlier is an empirical study of a single protein that typically would be involved as one of the constituting parts of a Behesystem. Protein sequence space may look like a limitless desert of maladjusted sequences with only a few oases of working sequences, as outlined by the experiments by Axe. Yet another study exami- 
nes the probability of finding ATP binding proteins from a random sample of sequence space regardless of the fold. ${ }^{57}$ The authors estimated a probability of 1 in $10^{11}$ to find an ATP binding protein, suggesting a higher probability than found by Axe. Recently Kozulic and Leisola $^{58}$ made careful analyses of these results, and concluded that even with very conservative conditions, the probability of finding ATP binding activity that would function in a cell, would be less than 1 in 1032. Estimates like these depend on various factors, including the length of the proteins considered, and indicate that while the probability of finding a functional protein in sequence space can vary broadly it commonly remains far beyond the reach of Darwinian processes. ${ }^{59}$ Some authors have even suggested that the original amino acid repertoire consisted of only four or five amino acids, to reduce the gigantic sequence space, and 'rule out the big number game'.60 However, this would need another type of genetic code, something considered highly speculative.

The protein argument is based on a standard statistical estimation of prevalence, i.e. the proportion of a population who have a specific characteristic or pattern (working proteins). Such studies are commonly performed by examining a randomly selected sample from the entire population. The proteins of life are found to be specific kinds of events with low probability.

\section{ID as science?}

The idea that nature is a closed system of natural causes, and that natural causes provide a complete account of everything that occurs in nature, is deeply rooted in natural science. Natural causes, as the scientific community usually understands them, are causes that operate according to deterministic and non-deterministic laws that can be characterized in terms of chance, necessity, or their combination (cf. Jacques Monod's Chance and Necessity). However, a fundamental element of ID is that the observed features, even when conditioned by a physical system that embodies it, cannot be reduced to such a natural account without remainder. Within the ID literature, that remainder is typically identified as some form of complexity: 'functional complexity' (Marcel Schutzenberger), 'irreducible complexity' (Michael Behe), and 'specified complexity' (William Dembski). It is not complexity alone that is the basis for the claims about ID, it is rather a duality, a particular complexity of dual nature that we have discovered in biology.

Humans have a powerful intuitive understanding of design that precedes modern science. Our common intuitions invariably begin with recognizing pattern and design. The problem has been that our intuitions about design have been unrefined and pre-theoretical. There is no surprise that ID is as controversial as it highlights a gap between common culture, which is largely committed to ID reasoning, and scientific culture, which largely rejects it in favor of Darwinian naturalism. Darwinism has been well developed and extensively advertised within science. ID is turning the tables on this disparity by promising to place the rough and pre-theoretical intuitions on a firm rational foundation, and thus promote a supplementary add-on to Darwinian Theory and the competing claims of Darwinism.

One main methodological constraint that often is used to keep ID outside of natural sciences is the framework of methodological naturalism. According to metho- 
dological naturalism, in categorizing any natural phenomenon, the natural sciences are properly permitted to invoke only natural processes, to the exclusion of ID descriptions. Methodological naturalism is a regulative framework that purports to keep science on the straight and narrow by limiting science to natural causes. The widespread philosophical opinion conceives methodological naturalism as an intrinsic and self-imposed limitation of science, as a 'ground rule' and a basic element of the scientific enterprise by definition. ${ }^{61}$

Reconciling science and religion on the basis of methodological naturalism happens at the expense of philosophical and scientific integrity, and it is therefore misguided. It leaves the public with the impression that evolution by natural selection appears to win the scientific debate only because ID with its prearrangements or configurations, is already carefully excluded from the outset. ${ }^{62}$ One cost that goes along with methodological naturalism is that one cannot claim that science, at least when it theorizes about origins, purports to tell us the truth about the world, but only that science gives us the best naturalistic story. This moves finding truth about several important questions of origins outside the domain of science, to terra incognito, philosophy or theology.

Steve Fuller and others are critical of claims that science has to be 'methodologically naturalistic.' 63 If an intelligence actually played a crucial role in the origin of biological complexity, practicing a strict methodological naturalism would actively hinder the progress of science. A more open position described as pragmatic naturalism (cf. Ludwig Wittgenstein) simply wants to understand nature and does not care what entities are involved to facilitate that understanding, as long as they prove conceptually fruitful. Pragmatic naturalism places no restraint on Intelligent Design. ${ }^{64}$

The main methodic difference between ID supporters and the opposition is the adherence to methodological naturalism. Many scientists require a purely natural explanation for all effects, while proponents of ID are open to intelligent causation in a metaphysical context for the empirical results we observe, and do not rule out such ideas a priori. The preprogramming of an ID-system is due to the presence of great amounts of information in the finely tuned initial conditions. In science, modelling a system frequently amounts to handling an initial value problem. This is a well-known scientific approach.

Thomas Kuhn openly acknowledged that metaphysics and values were an integral part of science and scientific change, because these were inherent to any usual paradigm. ${ }^{65}$ Metaphysics should not be looked upon with lack of respect, but as a necessary part of doing science. Furthermore, he acknowledged that we do not have a direct, neutral knowledge of reality, but that all of our perceptions are partly colored by our presuppositions, assumptions, and values, so that strong claims to objective knowledge needed to be treated with caution. While the inspiration of work in ID and its 'context of discovery' may be religious, this needs not to be any bar to its counting as scientific in its successive 'context of justification'. ID may have some theological inspiration and implications, but that does not sort it out as a theological enterprise.

\section{Some interpretations of ID}

There may be no single interpretation of ID that is generally valid to all times and 


\begin{tabular}{|l|l|l|l|}
\hline Empirical data & Method & Category (scientific) & $\begin{array}{l}\text { Interpretation } \\
\text { (Nat. Theology) }\end{array}$ \\
\hline Fine-tuned physics & Abductive inference & $\begin{array}{l}\text { Design } \\
\text { (or multiverse) }\end{array}$ & God's creation \\
\hline Carbon resonance & Physics deduction & Design & God's creation \\
\hline Proteins & Statistical estimation & Design & Sod's creation \\
\hline Molecular motors & $\begin{array}{l}\text { Statistical estimation } \\
\text { (preliminary) }\end{array}$ & (Design) & \\
\hline
\end{tabular}

Table 1. A hierarchical overview of scientific data, methods, and category of the ID-arguments in this paper. Methods at each line are based on the existence of data and material one line higher up in the table. The scientific parts are shown in the three columns to the left. Interpretations within the framework of Natural Theology are added in the 4th column.

places. Such interpretation must be handled in social and philosophic context. How we understand nature and rationality is in principle framework-dependent.

Within the strict framework of methodological naturalism, the interpretation is obliged to stay with the dialectics of chance and necessity, as Franklin Harold states it in one of his books. ${ }^{66}$ In the same book, he also admits that there are no detailed Darwinian accounts for these biological systems, 'only a variety of wishful speculations'. Others may denote this part of science as an enigma.

However, within a theistic or Christian framework, we may answer the apologetic question by saying that the Christian framework is clearly consistent with the observations at hand. It will be a very difficult task to argue that the only way to make sense of a certain observation is by appealing to the Christian framework, and it is a more manageable task to argue that certain scientific observations make better sense of the phenomenon within the Christian framework than without. One can make a cumulative case by combining different observations and argu- ments. However, natural theology is more than preaching to the converted as an internal confirmation of a Christian framework. By showing how a Christian framework may improve an otherwise non-theistic understanding of natural phenomena, one can argue that nature provides many open doors to a theistic framework. In this way, these arguments should challenge everyone, not only believers. ${ }^{67}$

It is well inside the scope of Natural Theology (NT) to look at some aspect of the natural world and thereby draw conclusions about some reality that extends beyond the natural world. This approach is non-reductionist. Instead of seeing nature as built from the ground up of mindless elementary constituents that come together through equally mindless forces, a revitalized natural theology may argue that a top-down purposiveness is central to a proper understanding of the world. Contemporary natural theologians point to the very existence of the world, the laws by which the world operates, the capacity of the world to organize itself, the fine-tuning and intelligibility 
of the world, and the unreasonable effectiveness of mathematics for comprehending the world as questions that nature raises but that also point beyond nature. The main results of our discussion is summarized in Table 1.

Alister McGrath qualifies NT in the following sense: Natural Theology is not about providing proof, it is about interpreting nature in light of the received Christian tradition. And when this interpretation makes sense of how we experience the world, there can be said to be 'a resonance' between this Christian framework and what is observed which gives the framework credibility. ${ }^{6}$

\section{Conclusion}

Darwinism has raised some challenging consequences for theology, and in questioning Darwinism, ID likewise has some important consequences for theology. This is not to say that ID is a theological initiative, any more than Darwinism is a theological initiative. ID conceived as a theory about the inherent limitations of natural causes to generate complexity, and the need for well-designed configuration in finely tuned initial conditions to overcome those limitations, is a scientific theory. Darwinism, conceived as a theory about how biological complexity has emerged in the history of life, is similarly a scientific theory. The laws, constants, and primordial initial conditions of nature present the flow of nature. These purely natural phenomena discovered in recent years show prospects of its being designed. Several cases of fine-tuned physics and biology are well-researched today and ready for the public arena.

Natural theologies were in their day first-rate instruments to educate people about the nature around us. For the church, this apologetic task is more neces- sary than ever before. Even though there is a huge difference between theological and scientific methodology, apologetic spokespersons should be willing to listen to scientists and be educated by them. There exists a common boundary between ID and NT, and the two may be considered close and interactive neighbors. At the boundary, questions are raised by science that cannot be answered by science alone. There are some obvious benefits to be gained from ID for contemporary theology. If theology wants to interact with secular culture, it should seek a better alliance with natural science. Here we have a position that places the burden of evidence on the shoulders of ID. The Christian philosopher William Lane Craig stated the fine-tuning argument in a 1998 debate with then atheist philosopher Antony Flew $^{69}$, and not long after this debate, Flew announced his conversion to a theistic worldview. 70

ID still needs to continue working on empirical criteria for identifying deliberately constructed products of intelligence. These criteria are necessary to make the explanations scientifically and philosophically legitimate. ID deserves attention in the scientific community as it competes with naturalistic macroevolution as a possible description for why things are the way they are. The basic notions behind ID is information-related. Within this setting, design promises to become an effective conceptual tool for investigating and understanding the natural world. The main motivation is to explore some fascinating possibilities for science and create room for new explorations.

Biologists need richer conceptual resources than the physical sciences have been able to generate. ${ }^{71}$ Yet ID has more work to do to establish itself better as a sustainable scientific theory, and ultima- 
tely a Design Science. Thus far, many theoretical and foundational concerns have tended to predominate. This may reflect the earliness of the hour and the need to clear the grounds before a shift of paradigms can take place. ID is a young scientific research program that wants to demonstrate its merits in the scientific world. Science has opened up to investigate several hypotheses about the nature of the physical and biological world that postulate design-like patterns at a funda- mental level. The results are of course most reliably answered retrospectively.

Nature is a mixed experience. ${ }^{72}$ It is not William Paley's happy world of everything in delicate balance and harmony. It is not the widely caricatured Darwinian world of struggle and survival of the fittest. Nature contains smart design and damaged design. Both science and theology need to come to terms with design as such and not dismiss it.

\section{Notes}

1 Ian G. Barbour, When Science Meets Religion: Enemies, Strangers, or Partners? (San Francisco: HarperOne, 2000).

2 Nathan J. Hallanger, "Ian G. Barbour" in The Blackwell Companion to Science and Christianity, eds. J.B. Stump and Alan G. Padgett (Malden, MA: Wiley-Blackwell, 2012), Chapter 52: 600-611. https://onlinelibrary.wiley.com/doi/pdf/10.1002/9781118241455.ch52

3 Del Ratzsch, "How Not to Critique Intelligent Design Theory” Ars Disputandi: The Online Journal for Philosophy of Religion, 5, 1-18 (2005).

4 Steinar Thorvaldsen \& Ola Hössjer "Using statistical methods to model the fine-tuning of molecular machines and systems" Journal of Theoretical Biology, vol. 501, 110352 (2020). Some parts of section 3 in the present paper are gained from this paper. http://dx.doi.org/10.1016/j.jtbi.2020.110352

5 Scott Mandelbrote, "The Uses of Natural Theology in Seventeenth-Century England", Science in Context, Vol 20 (3) (2007), pp. 451-480.

6 Steinar Thorvaldsen, "Kepler, Galileo, Newton and the Constructive Ideas of Modern Science" in Time, Reality and Transcendence in Rational Perspective, ed. Peter Øhrstrøm (Aalborg University Press, 2002), 11-38. Rodney Stark, For the Glory of God. How Monotheism Led to Reformations, Science, Witch-Hunts, and the End of Slavery (Princeton University Press, 2003).

7 Toby E. Huff, The Rise of Early Modern Science: Islam, China and the West (Cambridge: Cambridge University Press, 1993, 3rd Edition 2017).

Toby E. Huff, Intellectual Curiosity and the Scientific Revolution: A Global Perspective (Cambridge:

Cambridge University Press, 2010).

Peter Harrison, The Bible, Protestantism, and the Rise of Natural Science (Cambridge: Cambridge University Press, 2001)

Rodney Stark, For the Glory of God (Princeton: Princeton University Press, 2003).

8 John Lennox "Intelligent Design. Some Critical Reflections on the Current Debate” in Robert B. Steward (ed.), Intelligent Design. William A. Dembski \& Michael Ruse in Dialog (Fortress Press, 2007) pp. 179-195.

9 In recent years no less than 5 new editions of William Paley's classical book Natural Theology of 1802 have been published, i.e. Natural Theology, Oxford World's Classics, (Oxford: Oxford University Press, 2008)

10 Timothy Lenoir, "The Göttingen School and the development of transcendental Naturphilosophie in the Romantic Era” Stud Hist Biol, 5 (1981), 111-205.

https://web.stanford.edu/dept/HPST/TimLenoir/Publications/Lenoir_GottingenSchool.pdf Accessed 8.October 2018.

11 Ibid page xii.

12 Fernando Vidal \& Bernhard Kleeberg "Introduction: Knowledge, Belief, and the Impulse to Natural Theology" Science in Context, 20(3) (2007), pp.381-400.

13 Steinar Thorvaldsen \& Peter Øhrstrøm "Darwin's Perplexing Paradox: Intelligent Design in Nature" Perspectives in Biology and Medicine, 56(1) 2013, 78-98. https://muse.jhu.edu/article/509326/pdf

14 Psalm 19,2

15 Gillian Beer Darwin's Plots (Cambridge: University of Cambridge Press, 2000) 
16 T. Russell Hunter "Making a Theist out of Darwin: Asa Gray's Post-Darwinian Natural Theology"

Science \& Education, 21(7), (2012) 959-975.

https://link.springer.com/content/pdf/10.1007\%2Fs11191-011-9388-6.pdf

17 Lynn Barber, The heyday of natural history, (London: Jonathan Cape, 1980). See also Symposium on the Present Status of Natural Theology, The Journal of Philosophy. vol. 55(22), 1958, pp. 925-944.

18 William A. Dembski, Being as Communion: A Metaphysics of Information, p. 58, (Farnham: Ashgate, 2014).

19 Del Ratzsch, Nature, Design and Science (New York: State University of New York Press, 2001) p.5

20 Ibid p. 6.

21 Ibid p.9.

22 Steinar Thorvaldsen \& Peter Øhrstrøm "Darwin’s Perplexing Paradox: Intelligent Design in Nature.

Perspectives in Biology and Medicine" 56(1) 2013, 78-98.

23 Fred Hoyle \& Chandra Wickramasinghe, Evolution from Space, London, 1981/1984.

24 Steinar Thorvaldsen, The Unique Hoyle State of the Carbon Atom. Dialogo 2014, pp. 43 - 46.

https://munin.uit.no/handle/10037/11612

25 Fred Hoyle "The Universe - Past and Present Reflections, Engineering and Science, November 1981, p. 12. Also printed as an extended version" Annual Review of Astronomy and Astrophysics, vol. 20, 1982, pp. 1-35.

26 Owen Gingerich, God's Universe (Harvard: Harvard University Press, 2006) p.57.

27 Paul Davies The Goldilocks Enigma: Why Is the Universe Just Right for Life? (Bostron: Houghton Mifflin Harcourt, 2006) p. ix.

28 Brandon Carter, Large Number Coincidences and the Anthropic Principle in Cosmology. IAU Symposium 63: Confrontation of Cosmological Theories with Observational Data, (Dordrecht: Reidel, 1974) pp. 291-298.

29 Luke A. Barnes "The Fine-Tuning of the Universe for Intelligent Life. Publications of the Astronomical Society of Australia”, 29(4) 2012, pp. 529-564. https://doi.org/10.1071/AS12015. See also: Luke A. Barnes

"A Reasonable Little Question: A Formulation of the Fine-Tuning Argument" Ergo : an open access journal of philosophy. Vol.6, 2020, (20201021), pp.1220-1257. https://doi.org/10.3998/ergo.12405314.0006.042 and Fred C Adams, 2019, The degree of fine-tuning in our universe - and others. Physics reports, Vol.807, pp.1-111. https://doi.org/10.1016/j.physrep.2019.02.001

30 Geraint F. Lewis \& Luke A. Barnes: A Fortunate Universe: Life in a Finely Tuned Cosmos. (Cambridge: Cambridge University Press, 2016).

31 John D Barrow \& Frank J. Tipler, The Anthropic Cosmological Principle, (Oxford: Oxford University Press, 1988).

32 Martin Rees, Just Six Numbers: The Deep Forces that Shape the Universe. 1999.

33 Geraint F. Lewis \& Luke A. Barnes: A Fortunate Universe: Life in a Finely Tuned Cosmos. (Cambridge: Cambridge University Press, 2016) Forword p. xi

34 'Explore as much as we can': Nobel Prize winner Charles Townes on evolution, intelligent design, and the meaning of life. https://www.berkeley.edu/news/media/releases/2005/06/17_townes.shtml

35 Evgeny Epelbaum, Hermann Krebs, Timo A. Lähde, Dean Lee \& Ulf-G. Meißner "Viability of Carbon-Based Life as a Function of the Light Quark Mass" Physical Review Letters (2013) 110(11), 112502.

36 Peter R Wills "DNA as information" Phil. Trans. R. Soc. (2016) A.37420150417.

http://doi.org/10.1098/rsta.2015.0417

37 Bruce Alberts "The Cell as a Collection of Molecular Machines: Preparing the Next Generation of Molecular Biologists, Cell, vol. 92, (2018) pp. 291-294.

See also a special issue on Molecular Machines BioEssays, 2003 vol. 25(12).

38 Several scientists inspired ID, including professor A.E. Wilder-Smith: The Creation of Life. A Cybernetic Approach to Evolution, Harlow Shaw Publishers, 1970; Charles Thaxon: The Mystery of Life's Origin, Lewis and Stanley, 1984; Michael Denton: Evolution: A Theory in Crisis, Burnett Books, 1985.

39 Michel J. Behe, Darwin's Black Box: The Biochemical Challenge to Evolutio (New York: The Free Press, 1996), p.203

40 AMP: Adenosine Monophosphate is a nucleotide that is found in RNA and plays important role for intracellular signaling. Its delusive function is also used especially in diabetic products as bitterness suppressor.

41 Douglas D. Axe "Estimating the prevalence of protein sequences adopting functional enzyme folds" J Mol Biol. 341(5), 2004, pp.1295-1315. In his experiment, he used a functional sequence section of 150 amino acids of the antibiotic resistance protein called beta-lactamase. Axe has also given a popularized version of his argument in his book Undeniable: How Biology Confirms our Intuition that Life is Designed (San Fransisco: HarperOne, 2016)

42 Ibid p. 160. There is a helpful diagram of this in Undeniable on p. 162.

43 Del Ratzsch Nature, Design and Science (New York: State University of New York Press, 2001), p.60. 
44 Winston Ewert, Robert J. Marks II, and William A Dembski “On the Improbability of Algorithmic Specified Complexity” Southeastern Symposium on System Theory, IEEE, (Waco: Baylor Univ, 2013), pp. 68-70.

Winston Ewert, William A. Dembski, and Robert J. Marks II, “Algorithmic Specified Complexity” In Jonathan Bartlett (Ed.) et al., Engineering and the Ultimate: An Interdisciplinary Investigation of Order and Design in Nature and Craft (Blyth Institute Press, 2014) pp. 131-149.

45 Robert J. Marks II, William A. Dembski, and Winston Ewert Introduction to Evolutionary Informatics (New Yersy: World Scientific, 2017)

46 George D. Montanez “A Unified Model of Complex Specified information” Bio-complexity, 2018 (4), pp. 1-26. https://doi.org/10.5048/BIO-C.2018.4

47 William A. Dembski The Design Inference: Eliminating Chance Through Small Probabilities (Cambridge: Cambridge University Press, 1998) p. 8

48 Steve Fuller, Bradley Monton and Thomas Nagel, see ref. 63.

49 William A. Dembski, Being as Communion, p.128-129.

50 Douglas Walton “Abductive, presumptive and plausible arguments". Informal Logic, 21 (2) (2011): 141-169. Doi:10.22329/il.v21i2.2241

51 Vesa Palonen has published an online paper where he applies methods from Bayesian statistics to the fine-tuning argument. Bayesian methods are a special case of a more general type of abductive reasoning. Vesa Palonen, 2008, "Bayesian considerations on the multiverse explanation of cosmic fine-tuning", arXiv.org > physics > arXiv, https://arxiv.org/abs/0802.4013

52 Evgeny Epelbaum et al "Ab Initio Calculation of the Hoyle State” Phys. Rev. Lett. 106, 192501 (2011). https://doi-org.mime.uit.no/10.1103/PhysRevLett.106.192501

Timo A. Lähde et al., 2020, An update on fine-tunings in the triple-alpha process. Eur. Phys. J. A, 56 (3). https://doi.org/10.1140/epja/s10050-020-00093-0

53 Michael J. Behe, "Reply to my critics: A response to reviews of Darwin's Black Box: The Biochemical Challenge to Evolution” Biology and Philosophy 16 (2001):685-709.

Kenneth R. Miller "The flagellum unspun: the collapse of "irreducible complexity" In: Dembski WA and M Ruse, eds. Debating Design: From Darwin to DNA. (Cambridge: Cambridge University Press,2005) pp 81-97. William A. Dembski “Still Spinning Just Fine: A Response To Ken Miller: 1-12”: http://www.arn.org/docs2/news/wd_still_spinning.htm Accessed 6 November 2018.

M.J. Behe "Irreducible Complexity: Obstacle to Darwinian Evolution” in Dembski WA, Ruse M, eds. Debating Design: From Darwin to DNA. (Cambridge: Cambridge University Press, 2004) pp 352-370.

54 M.J. Pallen, \& N.J. Matzke "From the origin of species to the origin of bacterial flagella" Nature Reviews Microbiology, 4(10) (2006) pp. 784-790.

Michael Behe Darwin Devolves (San Fransisco: HarperOne, 2019) pp. 283-301.

55 Winston Ewert "Digital irreducible complexity: A survey of irreducible complexity in computer simulations” BIO-Complexity 2014 (1):1-10. http://bio-complexity.org/ojs/index.php/main/article/view/BIOC.2014.1 Accessed 8 November 2018.

56 William A. Dembski No free lunch: Why specified complexity cannot be purchased without intelligence. (Rowman \& Littlefield, 2002) chapter 5.10, pp. 289-310

57 Evandro Ferrada \& Andreas Wagner "Evolutionary Innovations and the Organization of Protein Functions in Genotype Space” PLOS ONE Vol 5(11) (2010( Article Number: e14172

58 Branko Kozulic \& Matti Leisola "Have Scientists Already Been Able to Surpass the Capabilities of Evolution?" viXra Biochemistry (2015) 1504.0130. http://vixra.org/bioch/1504 Accessed 8 November 2018. 59 Douglas D. Axe “The Case Against a Darwinian Origin of Protein Fold” BIO-Complexity, Vol 2010 (1), pp. 1-12. http://bio-complexity.org/ojs/index.php/main/article/view/BIO-C.2010.1 Accesses 8 November 2018

60 David T Dryden, Andrew R Thomson and John H White "How much of protein sequence space has been explored by life on Earth?” Journal of the Royal Society interface, Vol 5 (25) (2008) pp. 953-956.

61 Robert T. Pennock "Can't philosophers tell the difference between science and religion?: Demarcation revisited" Synthese, Vol. 178(2) (2011), pp. 177-206.

62 Maarten Boudry, Stefaan Blancke and Johan Braeckman, "Grist to the Mill of Anti-evolutionism: The Failed Strategy of Ruling the Supernatural Out of Science by Philosophical Fiat”, Science \& Education, 2012, Volume 21, Issue 8, pp 1151-1165

63 Steve Fuller, Dissent over Descent (Thriplow: Icon Books Ltd., 2008) Jeremy Shearmur, "Steve Fuller and Intelligent Design", Philosophy of the Social Sciences, 2010, 40(3) 433-445. DOI:

10.1177/0048393110368040 Bradley Monton, Seeking God in Science: An Atheist Defends Intelligent Design, 2009, Broadview Press Inc. Thomas Nagel, Mind and Cosmos: Why the Materialist Neo-Darwinian Conception of Nature is Almost Certainly False (Oxford: Oxford University Press, 2012) 
64 Williard Quine ”Naturalism; or, Living within one's means” Dialectica 49, 1995, pp. 251-262.

65 Thomas Kuhn, The Structure of Scientific Revolutions (Cham: Springer, 2015).

66 Franklin Harold The Way of the Cell (Oxford: Oxford University Press, 2001)

67 William Lane Craig \& J. P. Moreland (Eds.) The Blackwell Companion to Natural Theology (Oxford: Wiley-Blackwell, 2009)

68 Alister E. McGrath A Fine-Tuned Universe: The Quest for God in Science and Theology (Louisville, KY: Westminster John Knox, 2009) p. 218

69 Stan W. Wallace (Ed.), 2003, Does God Exist?: The Craig-Flew Debate. Routledge.

70 Antony Flew, There is a God. How the world's most notorious atheist changed his mind. (San Francisco: HarperOne, 2007) p. 32.

71 Del Ratzsch, "There is a place for intelligent design in the philosophy of biology: intelligent design in (philosophy of) biology: some legitimate roles" in Francisco José Ayala \& Robert Arp (eds.), Contemporary Debates in Philosophy of Biology (Oxford: Wiley-Blackwell, 2010) pp. 343-363.

72 Dietrich Bonhoeffer, Creation and Fall (Augsburg Fortress Publishers, 2007). 


\title{
Theofilos
}

A Nordic open access journal in Theology, Philosophy and Culture

Published by NLA University College - in partnership with Johannelund School of Theology

Available at www.theofilos.no

\section{Scientific Rebuttals to 'Ancient Aliens' as Popular Alternatives to Biblical History}

\author{
Peter S. Williams \\ Assistant Professor in Communication and Worldviews \\ NLA University College \\ peterswilliams@gmail.com
}

\begin{abstract}
Just as Christian apologists need to rebut the 'alternative' historical claims of The Book of Mormon, so they need to rebut claims about so-called 'ancient aliens'. These claims offer people with a secular worldview historical counter-narratives to biblical history that draw upon the scientific respectability of astrobiology and the search for extra-terrestrial intelligence (SETI). Rather than interacting with the specifics of 'ancient alien' narratives on a case-by-case basis, I argue that 'ancient alien' theories are intrinsically convoluted and highly ad hoc, and that multiple essential facets of such theories are disconfirmed by scientific evidence. Not only do we lack convincing evidence that extra-terrestrial intelligences have visited Earth, but SETI has provided observational evidence that suggests technologically advanced aliens simply don't exist, at least in our cosmic neighborhood. In sum, when it comes to 'ancient aliens', it's those who believe in 'ancient aliens', not Christians, who are swimming against the scientific evidence.
\end{abstract}

Keywords: Ancient Aliens, Biblical History, Extra-Terrestrial Intelligences, SETI

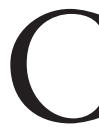

hristian apologetics should devote some attention to rebutting 'alternative' historical claims, whether those claims are contained in, for example, The Book of Mormon'1, or in the many books and television 'documentaries' that make claims about so-called 'ancient aliens'. Claims about 'ancient aliens' offer a counter-narrative to the biblical understanding of various historical and/or prehistorical events and figures, including the origins of humanity, the biblical prophets and the reality of the incarnation. These controverted subjects all feature within the apologetic fields of 'natural theology' or 'ramified natural theology' (see my paper on 'Science and Natural Theology in Contemporary Apologetic Context' earlier in this edition of Theofilos).

Proponents of 'ancient aliens' see the contradiction between their alien related beliefs and Christianity as a reason to doubt Christianity and thus Christian ramified natural theology. A legitimate but lengthy response to this doubt would be to offer a sufficiently robust positive apologetic for Christianity. This paper 
offers another legitimate, and more direct, response by critiquing the core tenants of 'ancient alien' beliefs, principally on the basis of scientific evidence.

At a methodological level, this paper can be viewed as a case study in addressing anti-Christian claims in contemporary popular culture by drawing upon data from culturally esteemed sources of evidence that constitute common ground between Christians and non-Christians (indeed, to avoid any appearance of bias, I will quote principally from secular sources). Rather than engaging with the specifics of the many different 'ancient alien' beliefs in contemporary culture, this paper focuses upon using evidence from multiple scientific fields (including physics, psychology, origin of life studies, astrobiology and the search for extra-terrestrial intelligence) to critique the key propositions that a) intelligent extra-terrestrials exist and that b) they have visited planet earth.

\section{Ancient Aliens in Contemporary Culture}

Narratives about alien visitors to Earth are given credence by the intellectually superficial bent of contemporary popular culture. As John A. Keel comments:

The E.T. [Extra-Terrestrial] premise has been promoted by the movies and by the UFO buffs so tenaciously the average person in the street now sort of accepts it, because they haven't given much thought to it. They don't realise how much of it is based upon wishful thinking and faulty logic. They have seen the movies or they have heard the UFO buffs on the radio or the TV and they say, 'Well, that make sense, we're being visited by aliens.'2

Such beliefs combine a superficial respect for science per se with ignorance of the relevant scientific data. Historical claims about ancient aliens get packaged into entertainment driven TV 'documentaries' and shared as YouTube videos that spread through our social media environment like the common cold among H.G. Well's ill-prepared Martian invaders. ${ }^{3}$

Journalist Fiona Macdonald defines 'fake news' as 'news from dubious sources, advertising content, or stories that are just totally made up - but which still go viral on Facebook and Twitter.' ${ }^{4}$ As an example of 'fake news', consider a July 2017 article from the website of wellknown British national newspaper The Sun:

LITTLE GREEN AMEN. Does this painting prove ALIENS were present at the Crucifixion of Jesus? Probably not . . . but that's what UFO watchers are claiming. The painting appears to show 'crafts' . . . but they might just represent guardian angels. ${ }^{5}$

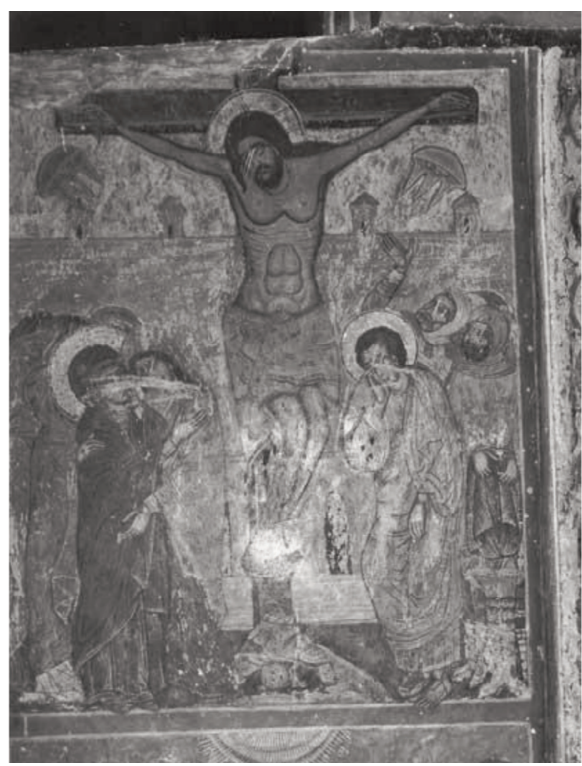

Illustration: The Crucifixion of Christ fresco, by unknown artist, Svetitskhoveli Cathedral in Georgia. ${ }^{6}$ 
Whilst stating that 'art historians who have studied the 11th century piece say the weird dome-shaped "crafts" [sic] represent guardian angels,' the Sun article contrasts this opinion with that of the website TheAncientAliens.com as if they were on a par: 'The unknown artist seems to be telling us that these flying saucers were present during the death of Jesus.' ${ }^{\text {T }}$

According to the TheAncientAliens.com website, from which the Sun article is clearly cribbed:

Art historians explain these to be representational of angels watching the event. However, angels were depicted with wings, and halos in Byzantine art of this time, as were all divine entities. We can see in this same painting that Jesus, Mary and John have halos. Others speculate these represent the sun and the moon. However, the sun and moon as personas was not accepted by christianity [sic]. The two objects were not given identities or deity status by the church as was the practice in Sumerian, Egypt and China. ${ }^{8}$

These comments reveal a startling ignorance of Christian theology and art (neither of which would portray Mary, John or angels as 'divine'). As a matter of fact, I haven't been able to find any art historian who thinks the objects in the Svetitskhoveli Cathedral crucifixion fresco are meant to be angels. Moreover, that an artist personifies the sun and moon doesn't entail attributing literal 'personas' to them, still less 'deity status'! According to Nigel Watson, author of the UFO Investigations Manual:

There are numerous examples of what to our modern eyes look like astronauts and spaceships in ancient and religious artworks. What we have to understand that artists in the past did not adhere to literal representations of things and often used symbolism to tell a story to give greater meaning to the picture. In this crucifixion of Christ the UFOs are representations of light (life) and darkness (death). Many artists painted the Sun and Moon, faces or angels to present these symbolic elements. Basically, there are no aliens to see here. ${ }^{9}$

As Italian art historian Diego Cuoghi reports: 'most of the crucifixions done in the Byzantine style show the same "objects" on either side of the cross. They are the Sun and the Moon, often represented with a human face or figure.'10 Cuoghi points out that those who consider such symbolic elements as representations of alien spacecraft:

assume that the artist, e.g. an Italian artist of the 15th century or an anonymous Byzantine painter, would actually be allowed to insert any non-canonical or un-codified element into a religious representation. On the contrary, in past times the commissioners (those who choose the subject and supervised the execution of the art work - in these cases the religious institutions) would have never allowed the author to insert into a work of art anything other than what [they] previously decided, especially in case of religious subjects. ${ }^{11}$

In short, this 'ancient aliens' story is fake news disguised with the form, but not the substance, of journalistic balance. Indeed, the superficially balanced opinions presented by the article appear to have both been drawn from one and the same unreliable source!

\section{A Brief History of Ancient Aliens and Modern Religion}

As theologian David Wilkinson observes: 
'The link between extraterrestrial intelligence and a religious quest has had a significant time in the last hundred years, with various new religious movements built on the mythology of aliens.'12

Science fiction author L. Ron Hubbard (1911-1986) founded the Church of Scientology in 1952, blending the 'ancient aliens' hypothesis with his 'Dianetics' system of 'auditing':

Auditing purports to identify spiritual distress from a person's current life and from past lives. Scientologists believe each person is an immortal being, a force that believers call a thetan. 'You move up the bridge to freedom by working toward being an "Operating Thetan," which at the highest level transcends material law,' says David Bromley, a professor of religious studies at Virginia Commonwealth University. 'You occasionally come across people in Scientology who say they can change the material world with their mind.' Bromley and other scholars say the church promotes the idea of an ancient intergalactic civilization in which millions of beings were destroyed and became what are known as 'body thetans,' which continue to latch onto humans and cause more trauma ... 'It's part therapy, part religion, part UFO group,' says Bromley. 13

In the mid 1950's, George King claimed to have been contacted by an alien named Aetherius and founded The Aetherius Society to promote the belief that Jesus was an alien. According to Mark Bennett, a contemporary member of The Aetherius Society:

it makes much more sense [to many people] to say that Jesus was an interplanetary being who came to Earth to help mankind, than to say that God created a one and only son, who was also himself at a random point in history, who came to come to earth and forgive people their sins for some reason we don't really know. ${ }^{14}$

Alternatively (and accommodating the existence of two independent historical birth accounts for Jesus ${ }^{15}$ ), it might be suggested that aliens 'implanted' Jesus into Mary's womb. ${ }^{16}$

Swiss UFO religion leader 'Billy' Eduard Albert Meier, who began publishing UFO photographs in the 1970's:

claims to be the seventh incarnation of the 'prophet' connecting Earth to the Plejaren [aliens]. The first incarnation was Henoch around 11,000 years ago followed by Elijah around 2,800 years ago, then Isiah, Jeremiah, and [Jesus Christ] around 2,000 years ago, and then Mohammed around 1,400 years ago. ${ }^{17}$

The Raëlian religion, founded by Claude Vorlihon (a.k.a. Raël), claims humans were created 25,000 years ago by aliens using genetic engineering, and that genetic engineering holds the key to eternal life. Vorlihon claims aliens visited him in 1973 and commissioned him to prepare humans for the second coming of their extraterrestrial creators by teaching a message of sexual freedom and eternal life through science:

According to Raël, all life on Earth was created by the Elohim, the same aliens who visited Vermillion. The Elohim have been appearing to humans for millennia, usually in the guise of angels or gods, passing on their message to humanity through human figures like Buddha and Jesus ... 18

(Raëlianism illustrates the logical gap between Intelligent Design Theory within 
the biological realm and design-based argumentation within natural theology. ${ }^{19}$ )

In his 1970 book Chariots of the Gods?, Erich von Däniken ${ }^{20}$ followed the Reverend John Miller ${ }^{21}$ in misinterpreting a vision of the prophet Ezekiel as an encounter with alien machinery; an oftdebunked theory that nevertheless continues to circulate. 22 To someone lacking background knowledge of ancient Jewish literature, such an interpretation has a superficially 'scientific' appeal, as Christian philosopher William Lane Craig testifies:

When I was in high school as a non-Christian young man I was really quite into UFOs and read a lot of the literature ... I remember seeing one article in a popular science magazine in which it claimed that Ezekiel's vision was of extraterrestrial beings in [a] sort of hovercraft and wearing helmets and things of this sort that he described in his primitive way as having the face of an ox and the face of an eagle and things of that sort. To me as a young high school teenager at the time it seemed very convincing . . . But as you become a little more sophisticated and understand Jewish apocalyptic literature and symbolism I think it makes it highly, highly unlikely that this was what Ezekiel was seeing; that this was in fact a typical sort of Jewish apocalyptic vision that he described . . .23

Recently, the popular TV series Ancient Aliens $^{24}$ 'purports to be an actual, independent, serious documentary series exploring the ancient astronaut theory [and] pays lip service to being "scientific".'25 In reality, Ancient Aliens offers up a mixture of "claims unsupported by evidence, leading questions [and] random facts marshalled with circular logic into self-referential "theories".'26 Science writer Andrew May explains that Ancient Aliens connects the idea of aliens 'to a whole range of myths, legends, structures and artefacts that already have perfectly adequate explanations in terms of the cultures they originated in . . .'27 As Vernon Macdonald observes: 'Every Ancient Aliens episode, whether dealing with ancient civilizations, artifacts or legends is always made up of some noxious combination of willful deception, wild speculation, and at times just plain stupidity.'28

\section{Popular Belief in Extra-Terrestrial Intelligences}

The impulse to re-interpret religion by invoking extra-terrestrial intelligences (ETI's) gains a superficial legitimacy from the fact that speculation about alien life (including intelligent aliens) is a scientifically respectable past-time known as astrobiology. Since the early 1960's, astrobiology has included the empirical research of the Search for Extra-Terrestrial Intelligence (SETI). ${ }^{29}$

Many people agree with atheist Richard Dawkins that 'there probably is intelligent life elsewhere in the Universe.' 30 A 2017 survey conducted in 24 countries showed that 47 percent of 26,000 respondents believed:

in the existence of intelligent alien civilizations in the universe ... Russians were the biggest believers - with whopping 68 percent saying they think intelligent alien life exists, trailed closely by Mexicans and Chinese respondents. The Netherlands ranked as the most skeptical of life beyond Earth, with only 28 percent of Dutch surveytakers entertaining in the possibility, according to the findings. ${ }^{31}$

According to recent polling: 
More than one in two people in the UK, Germany and the US believe there is intelligent life out there in the universe. The next time the subject comes up at the dinner table and you hear sniggers when someone admits they believe in aliens, it is worth remembering that it is not a fringe belief to think there is intelligent life out there - it is the mainstream viewpoint across the western world. 32

In 2017, a survey of 1700 Americans reported that $47 \%$ of those surveyed said they believe in aliens, while 39\% said they believe aliens have visited Earth before and $18 \%$ said they believed in alien abduction. ${ }^{33}$ According to a 2018 Cambridge University study, $8 \%$ of UK adults believe the government has covered up contact with aliens. ${ }^{34}$

Given this cultural background, even if they don't believe the sort of 'aliens explain away the supposedly supernatural elements of the Bible' theories advanced by the likes of von Däniken, many will think that since alien conspiracy theories have at least one foot in 'scientific reality', they are at least no less plausible than traditional, supernatural explanations of the same data. This viewpoint is expressed by journalist David Clarke:

If someone visits a church or mosque to worship we tend to treat their faith with respect. But if they visit a hilltop to charge a prayer battery on the orders of Master Artherius we write them off as 'crackpot' or 'UFO nut'. I could not see why the beliefs of those who claim that flying saucers bring messages from the gods should be regarded as any less genuinely held, or unbelievable, than the tenets of any other religion. ${ }^{35}$

Christian apologists shouldn't argue that the Artherians' beliefs are less 'genuinely held' than are Christian beliefs, but they should argue that they are more 'unbelievable' than Christian beliefs.

An instructive example of the need for Christian apologetics to engage with this issue comes from a question posed by an audience member after a talk on the resurrection by William Lane Craig:

I do find . . . the hypothesis that Jesus Christ was taken up into heaven by aliens to be as plausible as the resurrection. You know, I think one of them is absurd, but so's the other one, so what makes one more plausible than the other? 36

As Craig replied, in contrast to the resurrection hypothesis ${ }^{37}$, the ancient alien hypothesis is:

ad hoc and ... implausible ... In fact . . . given the religio-historical context of Jesus' life and teachings, the hypothesis that the God of Israel raised Jesus from the dead fits like a hand in a glove, whereas the alien abduction hypothesis is . . . completely ad hoc and out of left field and doesn't do anything to illuminate the religio-historical context. And I think this is especially true if, as I say, you have independent reasons to believe in the existence of God . . . so that we've already got the existence of a supernatural being in place when we come to the evidence for the resurrection. [That] would be analogous [to,] if before we came to the evidence for the resurrection, you already had good evidence that there are these extra-terrestrial aliens who've come to earth . . . That would make [the alien hypothesis] more plausible, if there were some evidence for that, but there just isn't; so I think the God hypothesis is much more plausible than that. ${ }^{38}$ 


\section{The Drake Equation}

Speaking scientifically, the existence of extra-terrestrial life of any kind remains an open question; 39 let alone the existence of intelligent alien life with the motive, means and opportunity to participate in a religious conspiracy on planet Earth! Contrary to popular opinion, 'Of the search for intelligent life in particular, many scientists are skeptical.'40.

The so-called 'Drake Equation', devised by American astronomer and astrophysicist Frank Drake, which is a 'formula designed to provide a rough numerical estimate of an unknown quantity'41, suggests that the number of detectable alien civilizations (N) can be estimated by multiplying:

- the rate of formation of stars suitable for life $\left(\mathrm{R}^{*}\right)$

- the fraction of those with planets (fp)

- the number of those planets that are suitable for life (ne)

- the fraction of these planets where life actually evolves (fl)

- the fraction of these on which intelligent life evolves (fi)

- the fraction of these that develop civilizations that produce detectable signs of their existence $(\mathrm{fc})$

- the length of time in which such civilizations will produce detectable signs of their existence $(\mathrm{L})$

That is:

- $\mathrm{N}=\mathrm{R}^{*} \mathrm{x}$ fp $\mathrm{x}$ ne $\mathrm{x}$ fl $\mathrm{x}$ fi $\mathrm{x}$ fc $\mathrm{x} \mathrm{L}$

According to Andrew May: 'The first factor in the Drake equation ... is the only one that's reasonably well established...
The other factors are subject to debate. . '42 Hence the value of $\mathrm{N}$ derived from this equation tends to owe more to the philosophical assumptions underlying the values assigned to its component parts than to scientific evidence. For materialists, the value of $\mathrm{N}$ principally hinges upon whether or not the evolution of sentient life by purely natural processes is a likely occurrence (i.e. upon the value of $\mathrm{fl} \times \mathrm{fi}$ ), for even many naturalists argue that (barring intelligent intervention of some kind) both the origin and subsequent macro-evolution of life (whether on Earth or elsewhere) are 'non-trivial' contingencies that cannot be taken for granted. 43

The pre-conditions for eukaryotic plant and animal life aren't as simple as the 'star plus rock plus water' formula popularized by media reports about the discovery of extra-solar planets! According to astrobiologist Lewis Dartnell: 'complex animal life ... may only be possible around Sun-like stars, on very Earthlike planets with plate tectonics, oceans of water, continental land, a thick oxygenrich atmosphere and large moon.' 44 Currently, despite the discovery of 'more than 4,000 exoplanets', ${ }^{45}$ no such planet is known besides our own. Peter Schenkel's observation continues to hold true: 'none of the detected planets around other starts comes close to having conditions apt ... for the development of even the most primitive forms of life, not to speak of more complex species. ${ }^{46}$

As Harvard biologist Itai Yanai admits: 'it is fair to say that all origins of life models suffer from astoundingly low probabilities of actually occurring. ${ }^{47}$ Atheist philosopher Thomas Nagel takes Richard Dawkins to task over the origin of life: 
Dawkins ... says that there are... a billion billion planets in the universe with life-friendly physical and chemical environments like ours. So all we have to suppose [to account for the origin of life on Earth] is that the probability of something like DNA forming ... is not much less than one in a billion billion ... [However] no one has a theory that would support anything remotely near such a high probability . . . at this point the origin of life remains, in light of what is known about the huge size, the extreme specificity, and the exquisite functional precision of the genetic material, a mystery . . .48

Eugene V. Koonin (Senior Investigator at the National Center for Biotechnology Information in Bethesda, USA) calculates that: 'in a finite universe ... the emergence of a coupled replication-translation system is unlikely to the extent of being, effectively, impossible.' 49 (To avoid the implication of design, Koonin turns to the ad $h o c$ and un-parsimonious hypothesis of a multiverse. ${ }^{50}$ ) Likewise, cosmologist and astrobiologist Paul Davies concludes:

we are probably the only intelligent beings in the observable universe, and I would not be very surprised if the solar system contains the only life in the observable universe. I arrive at this dismal conclusion because I see so many contingent features involved in the origin and evolution of life ...51

According to a 2018 analysis by physicists Anders Sandberg, Eric Drexler and Toby Ord, of the Future of Humanity Institute at Oxford University:

existing calculations for the probability of extra-terrestrial intelligent life ... rest on uncertainties and assumptions that lead to outcomes containing margins for error span- ning 'multiple orders of magnitude'. Constraining these, as much as possible, by factoring in models of plausible chemical and genetic mechanisms, results, they conclude, in the finding 'that there is a substantial probability that we are alone'. 52

The co-authors highlight:

critical questions regarding the emergence of life from non-living material - a process known as abiogenesis - and the subsequent likelihoods of early RNA-like life evolving into more adaptive DNA-like life. Then there is the essential matter of that primitive DNA-like life undergoing the sort of evolutionary symbiotic development that occurred on Earth, when a relationship between two different types of simple organisms resulted in the complex 'eukaryotic' cells that constitute every species on the planet more complicated than bacteria. 53

They conclude: 'When we take account of realistic uncertainty, replacing point estimates [in the Drake Equation] by probability distributions that reflect current scientific understanding, we find no reason to be highly confident that the galaxy (or observable universe) contains other civilizations. ${ }^{54}$

\section{Preconditions of Science}

It's one thing for intelligent aliens to exist, another for them to develop sophisticated technology. As botanist William C. Burger observes: 'Whether here on planet Earth or elsewhere in the universe, the assumption that since science happened once, science ought to happen often is wishful thinking.' 55 As biologist Michael Denton explains

the march of technological advance from the Stone Age ... was only 
possible because of what would appear to be an outrageously fortuitous set of environmental conditions, without which, despite our genius ... no advance beyond the most primitive stone tools would have been possible. ${ }^{56}$

According to Denton:

There is . . . every justification for viewing our planetary home with its oxygen-containing atmosphere, large land masses covered in trees, with its readily available and well scattered metal-bearing rocks as an ideal and perhaps unique environment for the use of fire and the development of metallurgy and ultimately the emergence of a technologically advanced complex society . . . ${ }^{57}$

Second, consider the fact that 'The scientific perspective flowered in Europe as an outworking of medieval biblical theology.' 58 As Paul Davies comments:

It was from the intellectual ferment brought about by the merging of Greek philosophy and Judeo-Islamic-Christian thought that modern science emerged, with its unidirectional linear time, its insistence on nature's rationality, and its emphasis on mathematical principles ... [Today] even the most atheistic scientist accepts as an act of faith that the universe is not absurd, that there is a rational basis to physical existence manifested as a lawlike order in nature that is at least in part comprehensible to us. ${ }^{59}$

Historian of science James Hannam confirms that 'the metaphysical background to Christianity turned out to be uniquely conducive to successfully understanding the working of nature . . . Christianity was a necessary, if not sufficient, cause of the flowering of modern science.' 60

Furthermore, it was Christian belief in the incarnation that elevated 'the dignity of matter and of manual work . . . Modern science was possible only when investigators became willing to dirty their hands in workshops and laboratories, and only when they began to see all material things, which have been created by God, as good in themselves.' ${ }^{61}$ In sum:

The origin of modern science and technology depend on a precise configuration of economic, cultural, philosophical, and theological precursors, and an unusually long-lasting and stable warm climate. Technology requires dexterity and a level of capacity to communicate that, of millions of known species of life, only humans possess. It also requires access to an oxygen-rich atmosphere, dry land, and concentrated ores. The laws of physics did not uniquely determine any of these. Until these factors came together, no civilization developed technology advanced enough to harness radio communication. And even on Earth, this has happened only once. What justification do we have for assuming that it's an inevitable result of life, even intelligent life, everywhere?62

Hence, as astrophysicist John Gribbin concludes: 'the kind of intelligent, technological civilization that has emerged on Earth may be unique, at least in our Milky Way Galaxy.'63 It would certainly seem that the burden of proof is on the ancient alien theorist.

\section{Close Encounters?}

Reports about alien space-craft, visitations and abductions (whether ancient or modern) fail to meet that burden of proof. As Stephen Hawking comments: 'I discount suggestions that UFOs contain beings from outer space, as I think that any visits by aliens would be much more 
obvious - and probably also much more unpleasant.'64 Such UFO reports as we have are generally susceptible to mundane explanations. ${ }^{65}$ Upon investigation, the vast majority of Unidentified Flying Objects (UFOs) become Identified Flying Objects of a non-alien nature. That some UFOs remain unidentified is, like the existence of unsolved crimes, hardly supportive of the hypothesis that ETI's exist.

Physicist Stephen Webb notes that 'the percentage of "inexplicable" UFOs does not vary much within the overall number of sightings ... whether it is a busy year or a quiet year for UFO sightings, the IFO/UFO ratio is about the same'66, which, he argues, is "not at all what one would expect if the "inexplicable" UFO sightings represent alien craft.' ${ }^{67}$ On the basis of this data, Robert Sheaffer concludes: 'the apparently unexplainable residue is due to the essentially random nature of gross misperception and misreporting.' 68

Astronomer Seth Shostak notes:

Our technology for documenting alien spacecraft ... is substantially better than even a few decades ago ... fabulous cameras are in the hands of nearly two billion smartphone users world-wide. And yet the UFO photos are as blurry and muddy as ever. You'd think at least a few people could make snaps that aren't ambiguous or hoaxed. And I haven't mentioned the surveillance provided by the 1,100 active satellites in orbit above our heads. ${ }^{69}$

In the judgement of psychologist Susan A. Clancy:

alien-abduction memories are best understood as resulting from a blend of fantasy-proneness, memory distortion, culturally available scripts, sleep hallucinations, and scientific illiteracy, aided and abet- ted by the suggestions and reinforcement of hypnotherapy. 70

The hypothesis that alien abduction experiences are delusional is supported by several recorded cases in which people have reported 'full-blown abduction experiences whilst other witnesses could see that the individual in question had not physically gone anywhere. Instead, they appear to have either lost consciousness or to be in a trance state'. ${ }^{71}$

In sum: 'The field of UFOlogy has failed to produce one concrete example of an alien visitation . . . the burden of proof remains squarely on the UFOlogists. ${ }^{7} 2$

\section{An Accumulating Evidence of Absent Aliens}

As far as we know, the only body in space to host life, or to have hosted life, is planet earth. As Andrew May observes: 'despite the thousands of exoplanets we've discovered over the last couple of decades, we've yet to find conclusive evidence of life on any of them. ${ }^{73}$

Mars may have been a habitable world with a global ocean for several billion years up until around four billion years ago $;^{74}$ but even supposing it were to be discovered that (most plausibly, microbial) life once existed (or even that life currently exists) on Mars,75 it may well have originated on Earth and have been transferred there on rocks from impact events, or vice versa, in which case it wouldn't be truly alien life. ${ }^{76}$

In the summer of 2020 a well-publicized paper in Nature Astronomy reported the claimed detection of phosphine gas in the atmosphere of Venus, gas that may be a biosignature (that is, an indicator of life). On the one hand, phosphine gas isn't a clear biosignature: 'Since the 1980s, scientists have theorised that phosphine is created by microbes in oxy- 
gen-free environments, like sewage sludge, but it is not a widely-accepted signature of life.' 77 According to Paul Byrne, Associate Professor of Planetary Science at North Carolina State University: 'If phosphine is confirmed beyond doubt to be present at Venus, it's very unlikely to be biotic in origin.' 78 On the other hand, subsequent analysis cast serious doubt on the claim that phosphine had been detected in the first place, at least at any significant level. ${ }^{79}$

Paul Davies notes that 'we can be pretty sure that there are zero prospects for intelligent life arising on any other planet in the solar system.' 80 Since the early 1960's, scientists have been searching for intelligent extraterrestrials beyond our solar system. Over a half century of this 'search for extra-terrestrial intelligence' (SETI) - 'mainly in the radio, but occasionally in the infrared and increasingly in the visible' 81 - has thus far produced a null result, despite rapid technological improvements in the field. 82 Historian of science George Basalla reports that 'Many SETI supporters expected extraterrestrial contact well before the coming of the millennium.'83 Consequently, as Stephen Webb observes: 'the continuing silence, despite intensive searches, is beginning to worry even some of the most enthusiastic proponents of SETI.' 84

Philosopher David Lamb argues:

Generous estimates of the number of planets with intelligent communicative life suffered a serious setback in 1992 following the completion of a radio search conducted by D.G. Blair . . The search covered the neighbourhoods of 176 stars . . - within forty light years of the Earth. No signal was detected. The negative results weaken [the] assumption that technological intelligence will inevitably emerge through enough time on an Earthsized planet near a Sun-like star. 85

Likewise, writing in a 2006 Skeptical Inquirer article, Peter Schenkel observed:

Since project OSMA I in 1959 by Frank Drake, about a hundred radio-magnetic and other searches were conducted in the U.S. and in other countries and a considerable part of our sky was scanned thoroughly and repeatedly, but it remained disappointingly silent ... If a hundred searches were unsuccessful, it is fair to deduce that estimates of a million or many thousands ETI are unsustainable propositions. ${ }^{86}$

Of particular note: 'Between 1995 and 2004, Project Phoenix used radio telescopes to look at hundreds of Sun-like stars within a couple of hundred light years of Earth without detecting any sign of alien civilization.' 87 Schenkel concludes that: 'Earth may be more special, and intelligence much rarer, than previously thought.' 88

More recent SETI projects, especially since the launch of the Kepler space telescope, have had the advantage of being guided by hard data about extra-solar planets.

Philosopher David R. Koepsell notes that there are about 500 [sun-like ' $G$ ' class] stars within a one-hundred lightyear radius of us: 'and so far, listening to them, we have heard nothing, although we have observed nearly 100 planets in that vicinity.' 89

A recent targeted search of ' 86 Kepler Objects of Interest . . . hosting [164] planet candidates judged to be most amenable to the presence of Earth-like life' 90 looked for narrow band radio emissions but found 'No signals of extraterrestrial 


\section{Exoplanet Discoveries Through the Years}

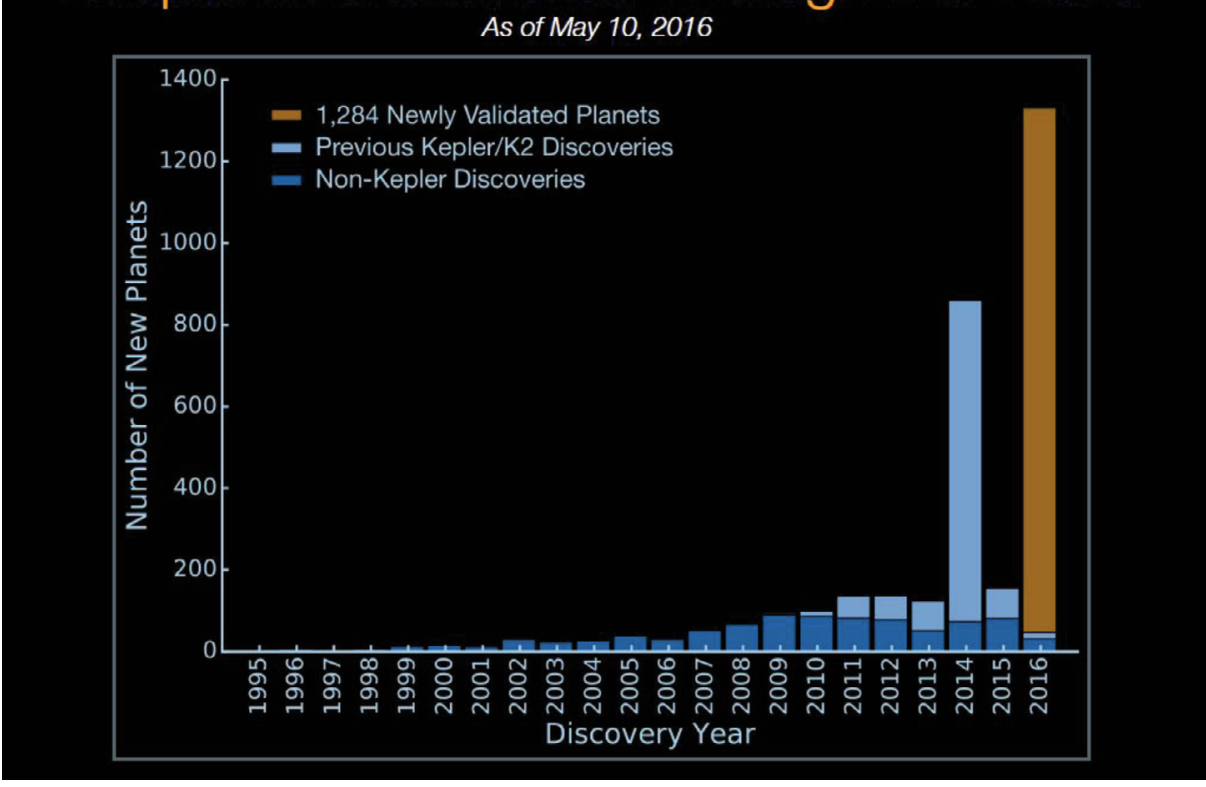

NASA

https://commons.wikimedia.org/wiki/File:ExoplanetDiscoveries-Histogram-20160510.jpg

origin . . . no evidence of advanced technology indicative of intelligent life', 91 thus 'placing limits on the presence of intelligent life in the galaxy . . .'92

In 2018 a paper by Jean-Luc Margot et al detailed the results of 'A Search for Technosignatures from 14 Planetary Systems in the Kepler Field with the Green Bank Telescope at $1.15-1.73$ GHz.' ${ }^{93}$ Focusing on 14 planetary systems, 858,748 candidate narrowband radio signals were analysed from within c. 420 and c. 13000 light-years of Earth, producing a short-list of 19 candidate signals. However, 'All of these candidates were observed in more than one direction on the sky, thereby ruling them out as extraterrestrial signals.' 94

In 2019, The Berkeley SETI Research Center 'Breakthrough Listen' project 'completed a comprehensive scan of 1,372 nearby stars, but no evidence of aliens was detected over the course of the threeyear survey.' 95 This search 'involved an analysis of 1,372 stars out of a total sample pool of 1,702 stars, none of which are farther than 160 light-years away. The survey included a wider variety of star types than usual, including stars that aren't similar to our Sun.'96 Study coauthor Andrew Siemion commented that: 'These results will . . . lead us toward further analysis that will place yet more stringent limits on the distribution of technologically capable life in the universe. . .'97

In 2020, a paper Dr Chenoa Tremblay and Professor Steven Tingay, of the International Centre for Radio Astronomy Research, published in the Publications of the Astronomical Society of Australia, detailed how they 'used the 
Murchison Widefield Array (MWA) telescope to explore hundreds of times more broadly than any previous search for extraterrestrial life.'98 This 'groundbreaking survey of over 10 million star systems' 99 observed the sky around the constellation of Vela ('a region of space known to contain at least six exoplanets'100), 'looking more than 100 times broader and deeper than ever before.'101 The researchers reported that: 'With this dataset we found no technosignatures no sign of intelligent life.'102

In recent decades, several extensive searches for alien optical emissions have been conducted:

- In December 2000, a Harvard-Smithsonian SETI project reported that almost 20,000 observations of nearly 5,000 sun-like stars had 'found no evidence for pulsed optical beacons from extraterrestrial civilizations.' 103

- In a 2015 paper, University of California Berkeley astronomers Nathaniel K. Tellis and Geoffrey Marcy 'present a search for laser emission coming from point sources in the vicinity of 2796 stars, including 1368 Kepler Objects of Interest (KOIs) that host one or more exoplanets' and note: 'We did not find any such laser emission coming from any of the 2796 target stars.' 104

- In a 2017 paper, Tellis and Marcy report being unable to detect any optical signatures from advanced civilizations in over 67,000 individual spectra produced within the planetary regions of 5,600 stars in the Milky Way:

We searched high resolution spectra of 5600 nearby stars for emission lines that are both inconsistent with a natural origin and unresolved spatially, as would be expected from extraterrestrial optical lasers .... We found no such laser emission coming from the planetary region around any of the 5600 stars. As they contain roughly 2000 lukewarm, Earth-size planets, we rule out models of the Milky Way in which over $0.1 \%$ of warm, Earth-size planets harbor technological civilizations that, intentionally or not, are beaming optical lasers toward us. ${ }^{105}$

Astronomers have also searched at the galactic level for the energetic signatures of any civilizations using much of a galaxy's starlight to satisfy their power requirements:

- In 1999 the Journal of the British Interplanetary Society reported the results of one such search, noting: 'For a sample of 137 galaxies, no such outliers are found.' 106

- In 2015 a Swedish study of 1359 spiral galaxies detected no signs of galactic scale civilization. ${ }^{107}$

- Also in 2015, another research group published the results of their extensive search for 'the thermodynamic consequences of galactic-scale colonization.' 108 According to Scientific American: 'After examining some 100,000 nearby large galaxies a team of researchers lead by The Pennsylvania State University astronomer Jason Wright has concluded that none of them contain any obvious signs of highly advanced technological civilizations.' ${ }^{109}$

This evidence isn't evidence for the cosmic absence of technologically advanced alien life per se (the observable universe is a very big place to search); but it does disconfirm the hypothesis that technologically advanced alien civilizations 
abound in or around our slice of space and time, ${ }^{110}$ a conclusion that in turn disconfirms historical theories involving extraterrestrial visitors.

\section{The Fermi Paradox}

The non-existence of technologically advanced ETI's is the simplest answer to 'the Fermi paradox - the contradiction between the apparent absence of aliens, and the common expectation that we should see evidence of their existence.'111 William Borucki, principal investigator of NASA's planet-hunting Kepler mission comments: 'We have . . . no visits, no communications we've picked up ... the evidence says, no one's out there.'112 Observing that 'we've seen no convincing evidence of other civilizations among the stars in our skies', astrobiologist Lewis Dartnell concludes that technologically sophisticated intelligent life 'may well be vanishingly rare in the Galaxy.'113 Andrew Norton, Professor of Astrophysics at the Open University concurs that 'intelligent, communicating life may well be extremely rare ... ${ }^{114}$ David Wilkinson concludes:

The Fermi paradox seems to indicate that the Galaxy is not teeming with alien civilizations ... we are either currently alone as an intelligent civilization in our Galaxy or ... civilizations are relatively few and quite late developers in the history of the Milky Way. This would receive support from those biologists who stress the unlikely evolution of intelligent life on other worlds. ${ }^{115}$

\section{Space is Very Big}

To quote Andrew May: 'As far as we know, the universe isn't literally "infinite", but it's very big.' 116 Even if technologically sophisticated ETI's exist, they probably lack the means of visiting us.
Richard Dawkins reckons that intelligent life 'is probably extremely rare and isolated on far-flung islands of life, like a celestial Polynesia' and consequently concludes that 'Visitations to one island by another are hugely more likely to be in the form of radio waves than visitations by corporeal beings.' ${ }^{117}$ Indeed, our closest extra-solar star (Proxima Centauri118) is 4.22 light years away!119

Dartnell comments that 'The laws of physics ... strongly constrain movement across the vast gulfs between stars.' 120 Although atheist physicist Lawrence M. Krauss finds it 'hard to believe that we are alone'121, he calculates that 'Energy expenditures beyond our current wildest dreams would be needed'122 to facilitate interstellar travel and so concludes that 'we probably don't have to worry too much about being abducted by aliens. ${ }^{123}$

What about interstellar travel using a so-called 'warp' drive (which hypothetically circumvents the light-speed limit by 'warping' space)? Krauss argues that the energetic requirements for such a drive are prohibitive:

The gravitational field near the surface of the Sun is miniscule in terms of the kind of gravitational effects required to perturb space-time [in the way required by a warp drive]. .. One way to estimate how much energy would have to be generated is to imagine producing a black hole of the size of the [fictional Star Trek ship] Enterprise - since certainly a black hole of this size would produce a gravitational field that could significantly bend any light beam that travelled near it ... it would take more than the total energy produced by the Sun during its entire lifetime to generate such a black hole. ${ }^{124}$

What about interstellar travel via a socalled 'wormhole'? In 2016 Ping Gao and 
Daniel Jafferis of Harvard University and Aron Wall of Stanford University described how 'a new species of traversable wormhole' 125 could theoretically result from the quantum coupling of two black holes linked by Hawking radiation, such that 'something tossed into one will shimmy along the wormhole and, following certain events in the outside universe, exit the second [albeit as Hawking radiation!].'126 Whilst the authors note that quantum coupling 'allows information to be recovered from black holes', they also note it means that 'the wormhole doesn't offer any superluminal boost . . .'127. Professor Robert Matthews comments:

calculations based on the wormhole types studied so far suggest that using them would actually be slower than simply travelling directly through space .. . The laws of nature seem to insist that wormholes can either perform amazing feats but collapse in an instant, or be traversable but useless. ${ }^{128}$

Krauss cautions: 'My understanding of wormholes is that we have no idea how to make them stable and traversable without exotic unknown forms of energy, so any discussion of traversable wormholes as realistic travel devices is highly speculative at best.'129

Nobel Prize winning theoretical physicist Kip Thorne muses that 'If a wormhole can be held open, the precise details of how remain a mystery', 130 and states: 'I doubt the laws of physics permit traversable wormholes . . .'131 He concludes: 'there are very strong indications that wormholes that a human could travel through are forbidden by the laws of physics . . .'132

Wormholes remain purely 'hypothetical constructs'.133 According to Dr Eric Christian and Dr Louis Barbier:
Wormholes are allowed to exist in the math of 'General Relativity' ... [So, if] general relativity is correct, there may be wormholes. But no one has any idea how they would be created, and there is no evidence for anything like a wormhole in the observed Universe. ${ }^{134}$

Krauss concludes: 'physics cannot give us what we need to roam the galaxy.'135 Once again, a substantial burden of proof falls upon anyone claiming aliens have visited Earth.

\section{Space is Very Dangerous}

Colliding with even very small objects can be hazardous in space, and this problem gets worse the faster one goes. At twenty percent of light-speed 'even individual atoms can damage the vehicle, and a collision with a bit of dust could be catastrophic.'136

Exposure to cosmic radiation increases the risk of fatal health problems in humans, and would plausibly be detrimental to any space-faring organic lifeform:

A recent study of the 24 astronauts who left Earth's low orbit on Nasa's Apollo missions in the 60s and 70s showed that they were five times more likely to die of heart disease than the astronauts who didn't enter deep space - a result scientists think may have been caused by excessive radiation exposure. Astronauts on missions at the [International Space Station] are shielded from too much radiation by Earth's atmosphere and magnetic field. But on a trip to Mars, humans would be exposed to radiation from the sun and from highenergy particles called galactic cosmic rays, which degrade DNA and drastically increase cancer risk. ${ }^{137}$ 
The further one travels, the worse this problem becomes, as one's exposure increases; and while increasing one's speed may reduce the temporal length of one's exposure to these health risks, it creates its own set of catastrophic problems:

as spaceship velocities approach the speed of light, interstellar hydrogen $\mathrm{H}$. . . turns into intense radiation that would quickly kill passengers and destroy electronic instrumentation. In addition, the energy loss of ionizing radiation passing through the ship's hull represents an increasing heat load that necessitates large expenditures of energy to cool the ship. Stopping or diverting this flux, either with material or electromagnetic shields, is a daunting problem. Going slow to avoid severe $\mathrm{H}$ irradiation sets an upper speed limit of $\mathrm{v} \sim 0.5 \mathrm{c}$. This velocity . . . would not substantially assist galaxy-scale voyages. Diffuse interstellar $\mathrm{H}$ atoms are the ultimate cosmic space mines and represent a formidable obstacle to interstellar travel. 138

In short: 'there's a natural speed limit imposed by safe levels of radiation due to hydrogen, which means [biological beings] couldn't travel faster than half the speed of light unless they were willing to die almost immediately.' 139 Of course, aliens might avoid the physiological (and psychological) problems of space travel ${ }^{140}$ by sending robots in their stead. However, that wouldn't negate the threat radiation poses for electronics, or the heat load it creates.

\section{Directed Panspermia?}

To explain the existence of life on Earth, some scientists invoke the hypothesis of 'panspermia', the idea that 'life didn't begin on Earth, but elsewhere in the uni- verse, and that it [or some ingredients thereof] was carried here on meteoroids and other space bodies.' ${ }^{141}$ However, the further this organic material is supposed to travel, the less likely it is to make or survive the journey. ${ }^{142}$ These problems are mitigated somewhat by the theory of 'directed panspermia', first proposed by Nobel laureate Francis Crick and originof-life researcher Leslie Orgel in an article published in Icarus (volume 19, 1973, 341-346).143 Crick expanded upon the hypothesis in his book Life Itself (Simon \& Schuster, 1981), suggesting that an advanced alien species sent one or more spacecraft to Earth with the intent of peppering it with the necessary life forms (or components of life) to generate a zoo of diverse species. However, even leaving aside the difficulties associated with transporting organic material through interstellar space, the hypothesis of 'directed panspermia' merely displaces the problem of abiogenesis without solving it. ${ }^{144}$

\section{Ad Hoc Aliens with Complex Schemes using Unlikely Hypothetical Technology?}

Even if technologically sophisticated aliens existed in our cosmic neighborhood, and had the means to visit Earth, it's far from certain that they would do so. As Dartnell observes: 'humanity has only been detectably civilised [that is, broadcasting radio waves] for about a century ...'145 Andrew May notes that if aliens were simply looking for natural resources, they'd 'probably find it more costeffective to pillage other parts of the Solar System instead. Rare elements would be far easier to extract from small asteroids than from the Earth, while water - if that's what they're after - is far more plentiful, in the form of ice, in the outer Solar System than it is on our own planet. ${ }^{146}$ 
But suppose, for the sake of argument, that ETI's visited first century Israel. Might they have used hypothetical technology to fake Jesus' 'resurrection' and other miracles (and if so, why)? Might a 'matter transporter' a la Star Trek have been used to remove Jesus' corpse from the tomb so he could be brought back to life somehow (using 'science') before being 'beamed' into the upper room to surprise the disciples? This hypothesis is not only ad hoc and complex but, given the scientific problems facing such hypothetical technology, highly unlikely. Krauss explains:

building a transporter would require us to heat up matter to a temperature a million times the temperature at the centre of the Sun, expend more energy in a single machine than all of humanity presently uses, build telescopes larger than the size of the Earth . . . and avoid the laws of quantum mechanics. ${ }^{147}$

Hence, as Davies warns: 'Speculation about alien super-civilizations doing super-science and deploying super-technology is certainly great fun, but it needs to be tempered with a healthy skepticism.' 148

\section{Conclusion}

The scientific evidence strongly suggests that, at least on a naturalistic worldview, the odds are against the existence of extra-terrestrial life. Even if extra-terrestrial life does exist, it seems unlikely (again, at least on a naturalistic worldview) that it would develop into anything complex, let alone intelligent. And even if extra-terrestrial intelligences (ETI's) exist, it seems unlikely (again, at least on a naturalistic worldview) that they'd be blessed with the ecological and cultural preconditions for the development of science and advanced technology.

Moreover, the scientific Search for Extra-Terrestrial Intelligence has provided observational evidence that suggests there are few if any technologically advanced ETI's in our cosmic neighborhood, and the non-existence of technologically advanced ETI's remains the simplest answer to 'the Fermi paradox'.

That said, even if some technologically advanced ETI's do exist in our cosmic neighborhood, there are significant psychological and physical barriers to interstellar travel, and even technologically advanced ETI's both willing and able to engage in interstellar travel wouldn't necessarily possess the motive, means and opportunity to visit Earth (especially in its pre-radio-signaling past). And even if they did, it seems unlikely that, for example, they'd both have and use the hypothetical technology required to convince a bunch of first century Jews that Jesus of Nazareth was the crucified-butrisen, miracle-working Son of Man. The compound improbability of any such sequence of events is prohibitive.

Theories about 'ancient aliens' being behind events of perceived religious significance are intrinsically convoluted (i.e. complex) and ad hoc, and have multiple essential facets that are strongly disconfirmed by scientific evidence available from secular sources. In sum, when it comes to 'ancient aliens', it's the conspiracy theorists and adherents of UFO religions, not Christians, who are swimming against the scientific evidence. 


\section{Recommended Resources}

\section{Watch:}

William Lane Craig, 'Is the Resurrection Hypothesis Really As Absurd as the Alien Hypothesis?’ https://youtu.be/QW97epVeN7Y

YouTube Playlist, 'Aliens \& UFOs' www.youtube.com/playlist?list=PLQhh3qcwVEWiixwhvDhbqSoO3qcIK7zu5

YouTube Playlist, 'The Origin of Life' www.youtube.com/playlist?list=PLQhh3qcwVEWggFeEP9H7k1Lyccfxzv0Sr

YouTube Playlist: 'The Rare Earth Hypothesis' www.youtube.com/playlist?list=PLQhh3qcwVEWiLU4H5kBr2JzSAzfIlTRst

YouTube Playlist, 'Physical Preconditions of Science \& Technology' www.youtube.com/playlist?list=PLQhh3qcwVEWiEbtcuD5f8bK0DHH31Lg6Y

YouTube Playlist, 'The Theological Roots of Science' www.youtube.com/playlist?list=PLQhh3qcwVEWh3jDVYqFFzWSnTbtlUeCg3

\section{Listen:}

Peter S. Williams, 'Ancient Aliens? Rebutting Alien Conspiracy Theories as Popular Alternatives to Biblical History' (ELF, 2020) http://podcast.peterswilliams.com/e/elf-2020-ancient-aliens-rebutting-alienconspiracy-theories-as-popular-alternatives-to-biblical-history/

Peter S. Williams, 'Scientific Rebuttals to Ancient Alien Conspiracy Theories as Popular Alternatives to Biblical History' (Veritas Symposium, 2018) http://podcast.peterswilliams.com/e/scientific-rebuttals-to-ancient-alienconspiracy-theories-as-popular-alternatives-to-biblical-history/

\section{Papers:}

J. Annis, 'Placing a limit on star-fed Kardashev type III civilisations' Journal of the British Interplanetary Society, Vol. 52, No. 1 (1999), 33-36

www.jbis.org.uk/paper.php? $\mathrm{p}=1999.52 .33$

Jason Colavito, Ancient Aliens: Unauthorized Reviews, www.jasoncolavito.com/ancient-aliens-reviews.html

Jon Coumes, 'Ancient Aliens is Everything That's Wrong With America' www.theawl.com/2017/09/ancient-aliens-is-everything-thats-wrong-with-america/ William Lane Craig, 'UFOs' www.reasonablefaith.org/media/reasonable-faith-podcast/ufos/

Diego Cuoghi, 'The Art of Imagining UFOs' www.diegocuoghi.com/arte-ufo/SKEPTIC_CUOGHI_ARTUFO_complete.pdf 
William A. Edelstein and Arthur D. Edelstein, 'Speed kills: Highly relativistic spaceflight would be fatal for passengers and instruments' Natural Science (Vol.4 No.10, October 2012) www.scirp.org/journal/PaperInformation.aspx?paperID=23913

Guillermo Gonzalez, 'Would Extraterrestrial Intelligent Life Spell Doom for Christianity?’ www.equip.org/article/would-extraterrestrial-intelligent-life-spelldoom-for-christianity/

Roger L. Griffith et al, 'The G Infrared Search For Extraterrestrial Civilizations With Large Energy Supplies' The Astrophysical Journal Supplement Series, 217:25 (April, 2015) http://iopscience.iop.org/article/10.1088/0067-0049/217/2/25/pdf

Sarah R. N. McIntyre et al, 'Planetary magnetism as a parameter in exoplanet habitability' Monthly Notices of the Royal Astronomical Society, Volume 485, Issue 3, May 2019, p. 3999-4012, https://doi.org/10.1093/mnras/stz667

Eric Manning, '5 Reasons Why Jesus Wasn't Resurrected by Aliens' https://isjesusalive.com/5-reasons-why-jesus-wasnt-resurrected-by-aliens/

Jean-Luc Margot et al, 'A Search for Technosignatures from 14 Planetary Systems in the Kepler Field with the Green Bank Telescope at 1.15-1.73 GHz' Astronomical Journal (April 25 th, 2018 )

http://iopscience.iop.org/article/10.3847/1538-3881/aabb03

Peter Schenkel, 'SETI Requires a Skeptical Reappraisal' Skeptical Inquirer, Volume 30.3 (May/June, 2006)

www.csicop.org/si/show/seti_requires_a_skeptical_reappraisal

Seth Shostak, 'Whatever happened to UFO sightings?' www.sfgate.com/ science/article/UFO-sightings-down-extraterrestrial-intelligence-6481669.php Andrew P.V. Siemion et al, 'A 1.1 to $1.9 \mathrm{GHz}$ SETI Survey of the Kepler Field' www.researchgate.net/publication/235359333_A_11_to_19_GHz_SETI_Survey_ of_the_Kepler_Field_I_A_Search_forNarrow-

band_Emission_from_Select_Targets

Chenoa Tremblay and Steven Tingay, 'A SETI Survey of the Vela Region using the Murchison Widefield Array: Orders of Magnitude Expansion in Search Space' Publications of the Astronomical Society of Australia (4th September, 2020), https://arxiv.org/pdf/2009.03267.pdf

Peter S. Williams, 'Raelians Successfully Clone Naturalism' www.arn.org/docs/williams/pw_raeliansclonenaturalism.htm

- 'Christianity, Space and Aliens'

www.bethinking.org/human-life/christianity-space-and-aliens http://iopscience.iop.org/article/10.1088/0004-637X/810/1/23/pdf 


\section{Books:}

George Bassala, Civilized Life In The Universe: Scientists On Intelligent Extraterrestrials (Oxford University Press, 2006)

William C. Berger, How Unique Are We? Perfect Planet, Clever Species (Prometheus, 2003)

Susan A. Clancy, Abducted: How People Come To Believe They Were Kidnapped By Aliens (Harvard University Press, 2005)

David Clarke, How UFOs Conquered The World: A History Of A Modern Myth (Aurum Press, 2015)

James Colavito, The Cult Of Alien Gods: H.P. Lovecraft and Extraterrestrial Pop Culture (Prometheus, 2005)

Lewis Dartnell, Life in the Universe: A Beginner's Guide, Astrobiology (OneWorld, 2007)

Paul Davies, The Eerie Silence: Searching for ourselves in the universe (Penguin, 2011)

Michael Denton, Fire Maker: How Humans Were Designed to Harness Fire and Transform Our Planet (Discovery Institute, 2016)

John Gribbin, Alone In The Universe: Why Our Planet Is Unique (Wiley, 2011)

David Lamb, The search for extraterrestrial intelligence: A Philosophical Investigation (Routledge, 2001)

David Waltham, Lucky Planet: Why Earth is Exceptional - and What that Means for Life in the Universe (Icon, 2015)

Peter C. Ward and Donald Brownlee, Rare Earth: Why Complex Life is Uncommon in the Universe (Springer, 2009)

Stephen Webb, Where Is Everybody? Fifty Solutions To The Fermi Paradox And The Problem Of Extraterrestrial Life (Copernicus, 2010)

David Wilkinson, Science, Religion, And The Search For Extraterrestrial Intelligence (Oxford, 2017) 


\section{Notes}

1 See: YouTube Playlist, 'Mormonism', www.youtube.com/playlist?list=PLQhh3qcwVEWjOn4gyNXipluUzVuNsJjji; Peter S. Williams, 'Mormonism - An Introductory Critique' http://podcast.peterswilliams.com/?s=Mormonism; James A. Beverley, Mormon Crisis: Anatomy of A Failing Religion (Burlington, Ontario: Castle Quay, 2013); Stan Larson, Quest for the Gold Plates: Thomas Stuart Ferguson's Archaeological Search for The Book of Mormon (Salt Lake City: Freethinker, 2004); Latayne C. Scott, The Mormon Mirage: A Former Member Looks at the Mormon Church Today, third edition (Grand Rapids, Michigan: Zondervan, 2009); Peter S, Williams, Getting at Jesus: A Comprehensive Critique of Neo-Atheist Nonsense About the Jesus of History (Eugene, Oregon: Wipf and Stock, 2019).

2 John Keel in David Clarke, How UFOs Conquered The World: A History Of A Modern Myth (London: Aurum Press, 2015), 243.

3 See: H.G. Wells, The War of the Worlds (London: Penguin, 2005).

${ }^{4}$ Fiona Macdonald, 'Bad news: $80 \%$ of students can't tell the difference between real and fake news' www.sciencealert.com/bad-news-study-finds-80-of-students-can-t-tell-the-difference-between-real-and-fakenews.

5 Sara Kamouni, The Sun (13th July 2017) www.thesun.co.uk/news/4014174/does-this-painting-prove-alienswere-present-at-the-crucifixion-of-jesus-probably-not-but-thats-what-ufo-watchers-are-claiming/. See also: Sean Martin, 'Aliens were present at Crucifixion of Jesus - and here's the "proof"' Express (14th July, 2017) www.express.co.uk/news/weird/828178/alien-jesus-christ-crucifixion-ufo; Rob Waugh, 'Painting "proves aliens were present at Christ's crucifixion", UFO fans claim' Metro (17 th July 2017)

https://metro.co.uk/2017/07/17/painting-proves-aliens-were-present-at-christs-crucifixion-ufo-fans-claim$6784461 /$.

6 Wikimedia commons, https://commons.wikimedia.org/wiki/File:Svetitskhoveli_Crucifixion_fresco.jpg.

7 Kamouni, The Sun.

8 'ALIENS IN ART: Crucifixion of Christ' www.theancientaliens.com/alien-art---crucifixion-of-christ.

9 Quoted by Rob Waugh, 'Painting "proves aliens were present at Christ's crucifixion”, UFO fans claim' Metro (17th July 2017) https://metro.co.uk/2017/07/17/painting-proves-aliens-were-present-at-christscrucifixion-ufo-fans-claim-6784461/?ito=cbshare.

10 Diego Cuoghi, 'ART and UFOs? No thanks, only art ... Part 2'

http://sprezzatura.it/Arte/Arte_UFO_2_eng.htm. See: Diego Cuoghi, 'The Art of Imagining UFOs' Skeptic Magazine (July, 2004) www.diegocuoghi.com/arte-ufo/SKEPTIC_CUOGHI_ARTUFO_complete.pdf.

11 Cuoghi, 'ART and UFOs? No thanks, only art ... Home' http://sprezzatura.it/Arte/Arte_UFO_eng.htm.

12 David Wilkinson, Religion, And The Search For Extraterrestrial Intelligence (Oxford: Oxford University Press, 2017), 13.

13 Dan Gilgoff and Tricia Escobedo, 'Scientology: What exactly is it?' https://edition.cnn.com/2017/03/22/us/believer-what-is-scientology/index.html.

14 Mark Bennett quoted by Alltime Conspiracies, 'Was Jesus an Alien?' www.alltimeconspiracies.com/was-jesus-an-alien/.

See also: Karl Mamer, 'Toronto Aetherius Society: Jesus, Venusians, and some bad astronomy (Part 1)' www.skepticnorth.com/2012/01/toronto-aetherius-society-jesus-venusians-and-some-bad-astronomy-part-1/ \& 'Toronto Aetherius Society: His Master's Voice, stuff that goes boom, and a lack of proof (Part 2)' www.skepticnorth.com/2012/01/toronto-aetherius-society-his-masters-voice-stuff-that-goes-boom-and-a-lackof-proof-part-2/.

15 See: Keith Ward, Evidence for the Virgin Birth (Christian Evidence Society) http://christianevidence.org/docs/booklets/evidence_for_the_virgin_birth.pdf; Paul Barnett, Messiab: Jesus the evidence of history (Nottingham: IVP, 2009); Brandon D. Crowe, Was Jesus Really Born Of A Virgin? (Glenside, PA: Westminster Seminary, 2013); Douglas Edwards, The Virgin Birth In History And Faith (London: Faber \& Faber, 1943); J. Gresham Machen, The Virgin Birth of Christ (Cambridge: James Clark \& Co. Ltd., 1958); Colin R. Nicholl, The Great Christ Comet: Revealing The True Star Of Bethlehem (Wheaton, Illinois: Crossway, 2015); Charles Quarles, Midrash Criticism: Introduction and Appraisal (Lanham, Maryland: University Press of America, 1998); John Redford, Born Of A Virgin: Proving the Miracle from the Gospels (London: St Pauls, 2007).

16 See: Alltime Conspiracies, 'Was Jesus an Alien?' https://youtu.be/Ey4eA0dAAN8; Glenn Millar, 'Question: Was Jesus of alien parentage?’ http://christianthinktank.com/alien2.html; David Wilkinson, Science, Religion, And The Search For Extraterrestrials (Oxford: Oxford University Press, 2017), 122.

17 Derek Bartholomaus, 'Who Is Billy Meier?' www.billymeierufocase.com/index-6.html. See also: Karl K. Korff, Spaceships of the Pleiades (Amherst, New York: Prometheus, 1996); Robert Sheaffer, UFO Sightings: The Evidence (Amherst, New York: Prometheus, 1998), 33-34. 
18 Mike Vago, 'Greetings from the UFO zealots who say aliens created life on Earth' (AV Club, 6/24/18) www.avclub.com/greetings-from-the-ufo-zealots-who-say-aliens-created-l-1826940199.

19 See: Peter S. Williams, 'Raelians Successfully Clone Naturalism'

www.arn.org/docs/williams/pw_raeliansclonenaturalism.htm.

20 See: Kenneth L. Felder, 'Ancient Astronauts' in Michael Shermer ed., The Skeptic: Encyclopedia of

Pseudoscience - Volume One (Santa Barbara, California: ABC-Clio, 2002),

https://camidrcs.files.wordpress.com/2018/02/skepticencyclopedia1.pdf.; John T. Omohundro, 'Von Däniken’s Chariots: A Primer in the Art of Cooked Science'

www.csicop.org/si/show/von_daumlnikenrsquos_chariots_a_primer_in_the_art_of_cooked_science.

21 See: Reverend John Miller STM, "Whirling Wheels: A Correlation of Flying Saucers and Visitors from Other Planets in The Bible' www.jasoncolavito.com/whirling-wheels.html.

22 See: 'Aliens of the Old Testament- Erich von Däniken: Beyond the Legend'

https://youtu.be/Vg5R2mFDkZk; Chris White, 'UFO In The Bible? Ezekiel' https://youtu.be/gm_6dnptTFA;

Kyle Butt, 'Ezekiel's Vision: An Alien UFO?'

www.apologeticspress.org/apcontent.aspx?category=11\&article=1061; Tim Callahan, 'The Spaceships of Ezekiel' www.skeptic.com/eskeptic/05-07-28/; J.F. Blumrich, The Spaceships of Ezekiel (London: Corgi, 1974).

23 William Lane Craig, 'UFOs' www.reasonablefaith.org/media/reasonable-faith-podcast/ufos/.

24 See: Jon Coumes, 'Ancient Aliens is Everything That's Wrong With America' The AWL (September, 2017) www.theawl.com/2017/09/ancient-aliens-is-everything-thats-wrong-with-america/; Jason Colavito, Ancient Aliens: Unauthorized Reviews, www.jasoncolavito.com/ancient-aliens-reviews.html; Jason Colavito, A Critical Companion to Ancient Aliens Series 3 \& 4 (Morrisville, North Carolina: Lulu, 2012).

25 Jason Colavito, A Critical Companion to Ancient Aliens Series 3 \& 4 (Morrisville, North Carolina: Lulu, 2012), 6 .

26 Colavito, A Critical Companion to Ancient Aliens, 33 \& 54.

27 Andrew May, Astrobiology (Hot Science) (London: Icon, Kindle Android version, 2019), 32.

See: Peter White, The Past Is Human (London: Angus and Robertson, 1976).

28 Vernon Macdonald, Ancient Aliens Exposed: Debunking UFOS, Ancient Astronauts and Other

Unexplained Mysteries (CreateSpace Independent Publishing Platform, Kindle, 2013), 91.

29 Daniel Oberhaus, 'A Brief History of Scientists Searching for Extraterrestrial Life' Vice (4 ${ }^{\text {th }}$ December, 2015) www.vice.com/en_us/article/jmaawd/a-brief-history-of-scientists-searching-for-extraterrestrial-life-124.

30 Richard Dawkins in Russell Stannard, Science and Wonders (London: Faber and Faber, 1996), 73.

31 Amanda Woods, 'Half of humans believe in alien life, study says' New York Post (8 ${ }^{\text {th }}$ December, 2017)

https://nypost.com/2017/12/08/half-of-humans-believe-in-alien-life-study-says/.

32 YouGov.uk 'You are not alone: most people believe that aliens exist'

https://yougov.co.uk/news/2015/09/24/you-are-not-alone-most-people-believe-aliens-exist/.

33 Alejandro Rojas, 'New survey shows nearly half of Americans believe in aliens' Huffington Post

$\left(2^{\text {nd }}\right.$ August, 2017) www.huffingtonpost.com/entry/new-survey-shows-nearly-half-of-americans-believein_us_59824c11e4b03d0624b0abe4.

34 Rich Haridy, 'From aliens to immigration, international study finds most believe a conspiracy theory' (New Atlas, November $30^{\text {th }} 2018$ ) https://newatlas.com/conspiracy-theory-belief-study-cambridge/57456/.

35 Clarke, How UFOs Conquered The World, 193.

36 William Lane Craig, 'Is the Resurrection Hypothesis Really As Absurd as the Alien Hypothesis?' https://youtu.be/QW97epVeN7Y.

37 See: Craig Blomberg and Carl Stecher with contributions by Richard Carrier and Peter S. Williams, Resurrection: Faith or Fact? A Scholars' Debate Between a Skeptic and a Christian (Durham, North Carolina: Pitchstone, 2019); Peter S. Williams, 'Resurrection: Faith or Fact? Miracle Not Required?'

Theofilos vol.11, nr 2 (2019) https://theofilos.no/wp-content/uploads/2020/03/Theofilos-vol.-11-nr.-2-2019-

Forum-3-Arkiv.pdf; Peter S. Williams, Getting at Jesus: A Comprehensive Critique of Neo-Atheist Nonsense about the Jesus of History (Eugene, Oregon: Wipf and Stock, 2019); Peter S. Williams, 'Addendum to Getting at Jesus: The Deceptive Demon or Daemon Hypothesis' (2019)'

www.peterswilliams.com/2020/01/19/addendum-to-getting-at-jesus-the-deceptive-demon-or-daemon-hypothesis/. 38 Craig, 'UFOs'.

39 On the recent (2020) claim that there is phosphine gas in the atmosphere of Venus that may be evidence for microbial life, see: Abigail Beall, 'Scientists found signs of life on Venus. Now they're not so sure' Wired $\left(29^{\text {th }}\right.$ October, 2020) www.wired.co.uk/article/venus-phosphine-life-questions; Lisa Grossman, 'Doubts over a "possible sign of life" on Venus show how science works' ScienceNews (October $28^{\text {th }}, 2020$ ) www.sciencenews.org/article/venus-phosphine-possible-sign-life-doubts-how-science-works.

40 Geoff Watts, 'Is There Life on Other Planets?' In Big Questions In Science, edited by Harriet Swain (London: Jonathan Cape, 2002), 203. 
41 May, Astrobiology, 32.

42 May, Astrobiology, 34.

43 See: YouTube Playlist, 'The Origin of Life'

www.youtube.com/playlist?list=PLQhh3qcwVEWggFeEP9H7k1Lyccfxzv0Sr; YouTube Playlist, 'Intelligent Design' www.youtube.com/playlist?list=PLQhh3qcwVEWjckJboK1rfuBKPcHiMFTSO; Stephen C. Meyer, 'DNA and the Origin of Life: Information, Specification, and Explanation' www.discovery.org/a/2184; James Tour, 'An Open Letter to My Colleagues' Interface: International Review of Science (Volume 3, Issue 2, $2^{\text {nd }}$ August, 2017) http://inference-review.com/article/an-open-letter-to-my-colleagues; David L. Abel, Primordial Prescription: The Most Plaguing Problem of Life Origin Science (Chicago, IL: Long View, 2015); Michael J. Behe, Darwin Devolves: The New Science about DNA That Challenges Evolution (New York: HarperOne, 2019); Michael J. Behe, The Edge of Evolution: The Search for the Limits of Darwinism (New York: Free Press, 2007); Michael J. Behe, Darwin's Black Box: The Biochemical Challenge to Evolution, $10^{\text {th }}$ Anniversary Edition (New York: Free Press, 2006); Donald E. Johnson, Programming of Life (Sylacauga, Alabama: Big Mac, 2010); David A. Klinghoffer ed., Debating Darwin's Doubt (Seattle: Discovery Institute, 2015); David A. Klinghoffer ed., Signature Of Controversy: Responses to Critics of Signature In The Cell (Seattle: Discovery Institute, 2010); Robert J. Marks II et al, Introduction To Evolutionary Informatics (Singapore: World Scientific, 2017); Stephen C. Meyers, Darwin's Doubt: The Explosive Origin of Animal Life and the Case for Intelligent Design (London: Bravo, 2014); Stephen C. Meyers, Signature in the Cell: DNA and the Evidence for Intelligent Design (New York: HarperOne, 2010); Stuart Pullen, Intelligent Design or Evolution? Why the Origin of Life and the Evolution of Molecular Knowledge Imply Design (Raleigh, NC: Intelligent Design, 2005); Charles B. Thaxton et al, The Mystery of Life's Origin: The Continuing Controversy (Seattle: Discovery Institute, 2020); Peter S. Williams, Outgrowing God? A Beginners' Guide to Richard Dawkins and the God Debate (Eugene, Oregon: Cascade, 2020).

44 Lewis Dartnell, Life in the Universe: A Beginner's Guide, Astrobiology (Oxford: OneWorld, 2007). See also: YouTube Playlist: 'The Rare Earth Hypothesis' https://youtu.be/dv353dia5uo; William C. Berger, How Unique Are We? Perfect Planet, Clever Species (Amherst, New York: Prometheus, 2003); Peter C. Ward and Donald Brownlee, Rare Earth: Why Complex Life is Uncommon in the Universe (New York: Springer, 2009); David Waltham, Lucky Planet: Why Earth is Exceptional - and What that Means for Life in the Universe (London: Icon, 2015).

45 May, Astrobiology, 103.

46 Peter Schenkel, 'SETI Requires a Skeptical Reappraisal' Skeptical Inquirer, Volume 30.3 (May/June, 2006) www.csicop.org/si/show/seti_requires_a_skeptical_reappraisal.

47 Itai Yanai in Eugene V. Koonin, 'The cosmological model of eternal inflation and the transition from chance to biological evolution in the history of life' Biology Direct $(2007,2: 15)$

www.biology-direct.com/content/2/1/15.

48 Thomas Nagel, 'Dawkins and Atheism' in Secular Philosophy and the Religious Temperament (Oxford: Oxford University Press, 2010), 24-25.

49 Eugene V. Koonin, 'The cosmological model of eternal inflation and the transition from chance to biological evolution in the history of life' Biology Direct (2007, 2:15) www.biology-direct.com/content/2/1/15.

50 William Lane Craig critiques the cosmological model that Koonin uses in 'Vilenkin's Cosmic Vision: A Review Essay of Many Worlds in One: The Search for Other Universes, by Alex Vilenkin' www.reasonablefaith.org/site/News2?page=NewsArticle\&id=7289. For a general critique of the multiverse, see my Outgrowing God? A Beginner's Guide to Richard Dawkins and the God Debate (Eugene, Oregon: Cascade, 2020).

51 Paul Davies, The Eerie Silence: Searching for ourselves in the universe (London: Penguin, 2011), 20752

52 Andrew Masterson, 'Stop looking for ET: modelling suggests we're alone in the universe' Cosmos (20 ${ }^{\text {th }}$ June 2018) https://cosmosmagazine.com/space/stop-looking-for-et-modelling-suggests-we-re-alone-in-the-universe.

53 Masterson, 'Stop looking for ET: modelling suggests we're alone in the universe'.

54 Masterson, 'Stop looking for ET: modelling suggests we're alone in the universe'.

55 William C. Berger, How Unique Are We? Perfect Planet, Clever Species (Amherst, New York: Prometheus, 2003), 270.

56 Michael Denton, Fire Maker: How Humans Were Designed to Harness Fire and Transform Our Planet (Seattle: Discovery Institute, 2016), 614. See also: Parker et al, ‘The Pyrophilic Primate Hypothesis,' 54-63; William C. Berger, How Unique Are We? Perfect Planet, Clever Species (Amherst, New York: Prometheus, 2003), 241-244.

57 Michael Denton, Nature's Destiny (New York: Simon \& Schuster, 1998), 394.

58 Vishal Mangalwadi, The Book That Made Your World (Nashville, TN: Thomas Nelson, 2011), 223.

See also: YouTube Playlist, 'The Theological Roots of Science'

www.youtube.com/playlist?list=PLQhh3qcwVEWh3jDVYqFFzWSnTbtlUeCg3; James Hannam, 'How

Christianity Led To The Rise Of Modern Science' www.equip.org/article/christianity-led-rise-modern-science/; 
William C. Berger, How Unique Are We? Perfect Planet, Clever Species (Amherst, New York: Prometheus, 2003), 251-270; Allan Chapman, Slaying The Dragons (Oxford: Lion, 2013); Edward Grant, A History Of Natural Philosophy (Cambridge: Cambridge University Press, 2007); James Hannam, God's Philosophers (London: Icon, 2010); Peter Harrison, The Bible, Protestantism the and Rise of Natural Science (Cambridge: Cambridge University Press, 2008).

59 Paul Davies, 'Physics and the Mind of God'

www.firstthings.com/article/1995/08/003-physics-and-the-mind-of-god-the-templeton-prize-address- 24 .

60 James Hannam, 'How Christianity Led To The Rise Of Modern Science'

www.equip.org/article/christianity-led-rise-modern-science/.

61 Robert C. Koons, 'Science and Theism: Concord, not Conflict'

http://robkoons.net/media/69b0dd04a9d2fc6dffff80b3ffffd524.pdf.

62 Guillermo Gonzalez and Jay W. Richards, The Privileged Planet: How Our Place In The Cosmos Is Designed For Discovery (Washington, D.C.: Regnery, 2004), 287-288. See also: William C. Berger,

How Unique Are We? Perfect Planet, Clever Species (Amherst, New York: Prometheus, 2003); Lewis

Dartnell, Life in the Universe: A Beginner's Guide, Astrobiology (Oxford: OneWorld, 2007), chapter eight; Michael Denton, Fire Maker: How Humans Were Designed to Harness Fire and Transform Our Planet (Seattle: Discovery Institute, 2016); Michael Denton, Nature's Destiny (New York: Simon \& Schuster, 1998); John Gribbin, Alone In The Universe: Why Our Planet Is Unique (Hoboken, New Jersey: Wiley, 2011), 204; Stephen Webb, Where Is Everybody? Fifty Solutions To The Fermi Paradox And The Problem Of Extraterrestrial Life (New York: Copernicus, 2010), 211-232.

63 John Gribbin, Alone In The Universe: Why Our Planet Is Unique (Hoboken, New Jersey: Wiley, 2011), xiv.

64 Stephen Hawking, Brief Answers To The Big Questions (London: John Murray, 2018), 83.

65 See: YouTube Playlist, 'Aliens \& UFOs'

www.youtube.com/playlist?list=PLQhh3qcwVEWiixwhvDhbqSoO3qcIK7zu5;

Nsikan Akpan and Joshua Barajas, '7 times that science explained aliens'

www.pbs.org/newshour/updates/7-times-aliens-explained-science/; Susan Blackmore, 'Abduction by Aliens or Sleep Paralysis?’ www.csicop.org/si/show/abduction_by_aliens_or_sleep_paralysis; Susan Blackmore and Marcus Cox, 'Alien Abductions, Sleep Paralysis and the Temporal Lobe'

www.susanblackmore.co.uk/articles/alien-abductions-sleep-paralysis-and-the-temporal-lobe/; Kenneth L. Feder, 'Help! I'm Being Followed by Ancient Aliens!'

www.csicop.org/si/show/help_im_being_followed_by_ancient_aliens; Christopher C. French, 'Close encounters of the psychological kind'

https://thepsychologist.bps.org.uk/volume-28/october-2015/close-encounters-psychological-kind; Christopher C. French et al, 'Psychological aspects of the alien contact experience'

https://research.gold.ac.uk/4223/2/French\%252Bet\%252Bal\%252BAliens\%252Bwith\%252BEffect \%252BSiz es\%252Baccept....pdf; Erich Goode, 'What About Alien Abductions?'

www.psychologytoday.com/blog/the-paranormal/201205/what-about-alien-abductions; Joe Nickell,

'Abductions and Hoaxes: The Man Who Attracts Aliens' www.csicop.org/si/show/abductions_and_hoaxes;

Joe Nickell, 'Navy Pilot's 2004 UFO: A Comedy of Errors' Skeptical Inquirer (Volume 42.3, May/June 2018) www.csicop.org/si/show/navy_pilots_2004_ufo_a_comedy_of_errors; John T. Omohundro, 'Von Däniken's Chariots: A Primer in the Art of Cooked Science'

www.csicop.org/si/show/von_daumlnikenrsquos_chariots_a_primer_in_the_art_of_cooked_science;

Kaja Perina, 'Alien Abductions: The Real Deal?'

www.psychologytoday.com/articles/200303/alien-abductions-the-real-deal; Susan A. Clancy, Abducted: How People Come To Believe They Were Kidnapped By Aliens (Cambridge, Massachusetts: Harvard University Press, 2005); David Clarke, How UFOs Conquered The World: A History Of A Modern Myth (London: Aurum Press, 2015); James Colavito, The Cult Of Alien Gods: H.P. Lovecraft and Extraterrestrial Pop Culture (Amherst, New York: Prometheus, 2005); Christopher C. French, 'Alien contact and abduction claims' in David Groome and Ron Roberts ed.'s, Parapsychology: The Science of Unusual Experience, second edition (London: Routledge, 2017); Robert Sheaffer, UFO Sightings: The Evidence (Amherst, New York: Prometheus, 1998); Stephen Webb, Where Is Everybody? Fifty Solutions To The Fermi Paradox And The Problem Of Extraterrestrial Life (New York: Copernicus, 2010), 29-34; Peter White, The Past Is Human (Angus and Robertson, 1976).

66 Stephen Webb, Where Is Everybody? Fifty Solutions To The Fermi Paradox And The Problem Of Extraterrestrial Life (New York: Copernicus, 2010), 31.

67 Webb, Where Is Everybody?, 31.

68 Robert Sheaffer, 'An examination of the claims that extraterrestrial visitors to Earth are being observed' in Ben Zuckerman and Michael H. Hart ed.'s, Extraterrestrials: Where are they? (Cambridge: Cambridge University Press, 2009), 20-28.

69 Seth Shostak, 'Whatever happened to UFO sightings?' SFGate (2nd September, 2015) www.sfgate.com/science/article/UFO-sightings-down-extraterrestrial-intelligence-6481669.php. 
70 Susan A. Clancy, Abducted: How People Come To Believe They Were Kidnapped By Aliens (Cambridge, Massachusetts: Harvard University Press, 2005), 138. See also: Christopher C. French, 'Alien contact and abduction claims' in David Groome and Ron Roberts ed.'s, Parapsychology: The Science of Unusual Experience, second edition (London: Routledge, 2017), 48-64.

71 Christopher C. French, 'Alien contact and abduction claims' in David Groome and Ron Roberts ed.'s, Parapsychology: The Science of Unusual Experience, second edition (London: Routledge, 2017), 63.

72 Ian Ridpath, 'Flying Saucers Thirty Years On' New Scientist (July 14 $\left.{ }^{\text {th }} 1977\right), 79$.

73 May, Astrobiology, 107.

74 See: Susanna Kohler, 'Mars's Leaky Atmosphere and Habitability' https://aasnova.org/2018/05/30/marss-leaky-atmosphere-and-habitability/.

75 See: NASA, 'NASA Finds Ancient Organic Material, Mysterious Methane on Mars'

www.nasa.gov/press-release/nasa-finds-ancient-organic-material-mysterious-methane-on-mars; Science Daily, 'Scientists have modeled Mars climate to understand habitability'

www.sciencedaily.com/releases/2020/05/200511142150.htm; Sara Zaske, WSU News, 'Study finds organic molecules discovered by Curiosity Rover consistent with early life on Mars' https://news.wsu.edu/2020/03/05/ study-finds-organic-molecules-discovered-curiosity-rover-consistent-early-life-mars/.

76 See: Andrew May, Astrobiology (Hot Science) (London: Icon, Kindle Android version, 2019), 77; Nicole Mortillaro, 'Could life have started on Mars before coming to Earth? Possibly, new study suggests' www.cbc.ca/news/technology/mars-panspermia-1.5699671; Ethan Siegel, 'The 5 Possibilities For Life On Mars' https://medium.com/starts-with-a-bang/the-5-possibilities-for-life-on-mars-4fc1d2495c9c.

77 Abigail Beall, 'Scientists found signs of life on Venus. Now they're not so sure' Wired (29th October, 2020) www.wired.co.uk/article/venus-phosphine-life-questions.

78 Paul Byrne quoted by Abigail Beall, 'Scientists found signs of life on Venus. Now they're not so sure' Wired (29th October, 2020) www.wired.co.uk/article/venus-phosphine-life-questions.

79 See: Abigail Beall, 'Scientists found signs of life on Venus. Now they're not so sure' Wired (29th October, 2020) www.wired.co.uk/article/venus-phosphine-life-questions; Lisa Grossman, 'Doubts over a “possible sign of life" on Venus show how science works' ScienceNews (October $28^{\text {th }}, 2020$ )

www.sciencenews.org/article/venus-phosphine-possible-sign-life-doubts-how-science-works; Paul Voosen, 'Potential signs of life on Venus are fading fast' Science (27th November, 2020),

https://science.sciencemag.org/content/370/6520/1021.full; Mark Zastrow, 'Prospects for life on Venus dim in reanalysis of phosphine data' Astronomy (24th November, 2020),

https://astronomy.com/news/2020/11/prospects-for-life-on-venus-dim-in-reanalysis-of-phosphine-data.

80 Davies, The Eerie Silence, 17.

81 Webb, Where Is Everybody?, 101.

82 See: Stephen Webb, Where Is Everybody? (New York: Copernicus, 2010), 88-105.

83 George Bassala, Civilized Life In The Universe (Oxford: Oxford University Press, 2006), 167.

84 Webb, Where Is Everybody?, 25.

85 David Lamb, The search for extraterrestrial intelligence: A Philosophical Investigation (London:

Routledge, 2001), 55.

86 Peter Schenkel, 'SETI Requires a Skeptical Reappraisal' Skeptical Inquirer, Volume 30.3 (May/June, 2006) www.csicop.org/si/show/seti_requires_a_skeptical_reappraisal.

87 Jim Al-Khalili ed., Aliens - Science Asks: Is There Anyone Out There? (London: Profile, 2016), 3.

88 Schenkel, 'SETI Requires a Skeptical Reappraisal'.

89 David R. Koepsell, 'Drake Vs. Fermi: Skepticism And SETI' (12 $2^{\text {th }}$ April, 2016)

https://centerforinquiry.org/blog/drake_vs-_fermi_skepticism_and_seti/. See: 'G stars within 100 light-years' (2005) www.solstation.com/stars3/100-gs.htm. According to David Wilkinson, Project Phoenix surveyed

' 1,000 nearby stars similar to our Sun, out to a distance of 100 light-years.' - Science, Religion, And The Search For Extraterrestrial Intelligence (Oxford: Oxford University Press, 2017), 89.

90 Andrew P.V. Siemion et al, 'A 1.1 to 1.9 GHz SETI Survey of the Kepler Field', Astrophysical Journal (2013) www.researchgate.net/publication/235359333_A_11_to_19_GHz_SETI_Survey_of_the_Kepler_Field_ I_A_Search_forNarrow-band_Emission_from_Select_Targets.

91 Siemion et al, 'A 1.1 to $1.9 \mathrm{GHz}$ SETI Survey of the Kepler Field'.

92 Siemion et al, 'A 1.1 to 1.9 GHz SETI Survey of the Kepler Field'.

93 Jean-Luc Margot et al, 'A Search for Technosignatures from 14 Planetary Systems in the Kepler Field with the Green Bank Telescope at 1.15-1.73 GHz' Astronomical Journal (April 25 ${ }^{\text {th }}, 2018$ ) http://iopscience.iop.org/article/10.3847/1538-3881/aabb03.

94 Margot et al, 'A Search for Technosignatures from 14 Planetary Systems in the Kepler Field with the Green Bank Telescope at $1.15-1.73 \mathrm{GHz}$.

95 George Dvorsky, 'An Ambitious Search for Aliens Came Up Short - so Astrobiologists Are Thinking Bigger' https:/gizmodo.com/an-ambitious-search-for-aliens-came-up-short-so-astrob-1835658888. 
96 Dvorsky, 'An Ambitious Search for Aliens Came Up Short - so Astrobiologists Are Thinking Bigger'.

97 Siemion, quoted Dvorsky, 'An Ambitious Search for Aliens Came Up Short - so Astrobiologists Are Thinking Bigger'.

98 Curtin University, Media Release, 'Australian telescope finds no signs of alien technology in 10 million star systems'

https://news.curtin.edu.au/media-releases/australian-telescope-finds-no-signs-of-alien-technology-in-10-millionstar-systems/.

99 George Dvorsky, 'Another Sweeping Search for Aliens Comes Up Short'

https://gizmodo.com/another-sweeping-search-for-aliens-comes-up-short-1844983788.

100 Dvorsky, 'Another Sweeping Search for Aliens Comes Up Short'.

101 Curtin University, Media Release, 'Australian telescope finds no signs of alien technology in 10 million star systems' https://news.curtin.edu.au/media-releases/australian-telescope-finds-no-signs-of-alien-technologyin-10-million-star-systems/.

102 Curtin University, Media Release, 'Australian telescope finds no signs of alien technology in 10 million star systems'.

103 Paul Horowitz et al, 'Targeted and All-Sky Search for Nanosecond Optical Pulses at Harvard Smithsonian' http://seti.harvard.edu/oseti/oseti.pdf.

104 Nathaniel K. Tellis and Geoffrey Marcy, 'A search for optical laser emission using keck HIRES'

Publications of the Astronomical Society of the Pacific (2015), 127.

105 Nathaniel Tellis and Geoffrey Marcy, 'A Search for Laser Emission with Megawatt Thresholds from 5600 FGKM Stars’ https://arxiv.org/pdf/1704.02535.pdf.

106 J. Annis, 'Placing a limit on star-fed Kardashev type III civilisations' Journal of the British Interplanetary Society, Vol. 52, No. 1 (1999), 33-36 www.jbis.org.uk/paper.php?p=1999.52.33.

107 See: E. Zackrisson et al, 'Extragalactic SETI: The Tully-Fisher Relation As A Probe Of Dysonian Astroengineering In Disk Galaxies’ The Astrophysical Journal, 810:23 (12pp), 2015, September 1 http://iopscience.iop.org/article/10.1088/0004-637X/810/1/23/pdf.

108 Lee Billings, 'Alien Supercivilizations Absent from 100,000 Nearby Galaxies' Scientific American (April 17th, 2015) www.scientificamerican.com/article/alien-supercivilizations-absent-from-100-000-nearby-galaxies/.

See: Roger L. Griffith et al, 'The G Infrared Search For Extraterrestrial Civilizations With Large Energy

Supplies’ The Astrophysical Journal Supplement Series, 217:25 (April, 2015)

http://iopscience.iop.org/article/10.1088/0067-0049/217/2/25/pdf.

109 Billings, 'Alien Supercivilizations Absent from 100,000 Nearby Galaxies'. See also: 'The Fermi Paradox and Our Search for Alien Life' SciShow Space https://youtu.be/5tjnuVheDoY.

110 See: Claudio Grimaldi, 'Detection probability of non-natural signals in the Galaxy'

www.claudiogrimaldi.com/seti.html; Brian Koberlein, 'Alien Signals We Discover Could Be The Echoes Of Dead Worlds' Forbes (12 ${ }^{\text {th }}$ April 2018) www.forbes.com/sites/briankoberlein/2018/04/12/alien-signals-wediscover-could-be-the-echoes-of-dead-worlds/\#2e543ed0f3a5; Claudio Grimaldi and G.W. Marcy, 'Area coverage of expanding E.T. signals in the galaxy: SETI and Drake's N' www.researchgate.net/publication/323410411_Area_coverage_of_expanding_ET_signals_in_the_galaxy_SETI _and_Drake\%27s_N; Marko Horvat, 'Calculating the probability of detecting radio signals from alien civilizations’ https://arxiv.org/pdf/0707.0011.pdf.

111 Webb, Where Is Everybody?, ix.

112 Borucki quoted in Ben Westcott, "No One's Out There': We're Likely Alone in the Milky Way, says Shaw Prize Astronomy Winner as he Visits Hong Kong for Award Ceremony' South China Morning Post (24 ${ }^{\text {th }}$ September, 2015) www.scmp.com/news/hong-kong/health-environment/article/1860781/no-ones-out-thereshaw-prize-astronomy-winner-says.

113 Lewis Dartnell, '(Un)welcome Visitors: Why Aliens Might Visit Us' in Al-Khalili ed., Aliens - Science Asks: Is There Anyone Out There?, 25.

114 Andrew Norton, 'Ross 128 Mystery Signals Aren't From Aliens' Newsweek (18 ${ }^{\text {th }}$ July, 2017) www.newsweek.com/ross-128-mystery-signals-aliens-what-happens-638172.

115 Wilkinson, Religion, And The Search For Extraterrestrial Intelligence, 115.

116 May, Astrobiology, 18.

117 Richard Dawkins, Science In The Soul (London: Black Swan, 2018), 210.

118 Proxima Centauri is a red dwarf star that probably doesn't have any habitable planets. See: Lina Tran, 'An Earth-like Atmosphere May Not Survive Proxima b's Orbit'

www.nasa.gov/feature/goddard/2017/an-earth-like-atmosphere-may-not-survive-proxima-b-s-orbit/; Katie Mack, “Goldilocks' planets might not be so nice' Cosmos (6 ${ }^{\text {th }}$ January, 2017)

https://cosmosmagazine.com/space/goldilocks-planets-might-not-be-so-nice; Nicola Davis, 'Proxima b: could we live on this newly found planet - or could something else?' The Guardian (27th August, 2016) www.theguardian.com/science/2016/aug/27/proxima-b-could-we-live-on-this-newly-found-planet-or-couldsomething-else. 
119 One light year is the distance light travels in one year, being 'roughly 9.5 billion $\mathrm{km}$ or 5.9 billion miles' - Gribbin, op cit, 1.

120 Dartnell, ‘(Un)welcome Visitors', 31.

121 Lawrence W. Krauss, The Physics of Star Trek (London: Flamingo, 1996), 127.

122 Krauss, The Physics of Star Trek, 128.

123 Krauss, The Physics of Star Trek, 128.

124 Krauss, The Physics of Star Trek, 60. See also: Michael White, The Science Of The X Files (London: Little, Brown, 1996), 18-19.

125 Natalie Wolchover, 'Newfound Wormhole Allows Information to Escape Black Holes' Quanta Magazine $\left(23^{\text {rd }}\right.$ October, 2017) www.quantamagazine.org/newfound-wormhole-allows-information-to-escape-blackholes-20171023/.

126 Wolchover, 'Newfound Wormhole Allows Information to Escape Black Holes'.

127 Wolchover, 'Newfound Wormhole Allows Information to Escape Black Holes'.

128 Robert Matthews, 'Through The Wormhole' in Focus (June, 2018), 44.

129 Lawrence W. Krauss, quoted by NBC News, 'Interstellar Reality Check'.

130 Kip Thorne, The Science of Interstellar (New York: W.W. Norton \& Company, 2014), 132.

131 Thorne, The Science of Interstellar, 136.

132 Kip Thorne, quoted by Nola Taylor Redd, 'What is a Wormhole?'

www.space.com/20881-wormholes.html.

133 Al-Khalili, Paradox: The Nine Greatest Enigmas in Physics (London: Black Swan, 2013), 203.

134 NASA, 'Space Physics: Wormholes, Time Travel, and Faster-Than-Speed-of-Light Theories'

https://helios.gsfc.nasa.gov/qa_sp_sl.htm.

135 Krauss, The Physics of Star Trek, 61.

136 John Timmer, 'Just how dangerous is it to travel at $20 \%$ the speed of light?'

https://arstechnica.com/science/2016/08/could-breakthrough-starshots-ships-survive-the-trip/.

137 Marisa Taylor, 'Heart disease, depression and blindness - the hazards of deep space travel' The Guardian (29th July, 2016) www.theguardian.com/lifeandstyle/2016/jul/29/space-travel-side-effects-scott-kelly-nasamars-astronauts-ross-3-mins.

138 William A. Edelstein and Arthur D. Edelstein, 'Speed kills: Highly relativistic spaceflight would be fatal for passengers and instruments' Natural Science, Vol.4 No.10 (October, 2012)

www.scirp.org/journal/PaperInformation.aspx?paperID=23913.

139 Jamie Condliffe, 'Super-Fast Space Travel Would Kill You in Minutes' Gizmodo (11/05/2012)

https://gizmodo.com/5957697/super-fast-space-travel-would-kill-you-in-minutes.

140 Ed Regis, 'Interstellar Travel as Delusional Fantasy [Excerpt]' Scientific American (October $3^{\text {rd }}$, 2015) www.scientificamerican.com/article/interstellar-travel-as-delusional-fantasy-excerpt/. Philosopher David R. Koepsell writes that: 'As a radio-communicating species, our presence would so far only be known to other radio-listening species within a 100 light year radius of us. There are about 500 ['G' type] stars within that radius, and so far, listening to them, we have heard nothing, although we have observed nearly 100 planets in that vicinity.' - 'Drake Vs. Fermi: Skepticism And SETI' (12 ${ }^{\text {th }}$ April, 2016)

https://centerforinquiry.org/blog/drake_vs-_fermi_skepticism_and_seti/.

141 Michael Marshall, 'Panspermia' www.newscientist.com/term/panspermia/\#ixzz6dZZRx7g6. See also: Jesse C. Mcnichol and Richard Gordon, 'Are We from Outer Space? A Critical Review of the Panspermia Hypothesis' www.ncbi.nlm.nih.gov/pmc/articles/PMC7121572/; Edward J. Steele et al, 'Cause of Cambrian Explosion - Terrestrial or Cosmic?', Progress in Biophysics and Molecular Biology (Volume 136, August 2018) www.sciencedirect.com/science/article/pii/S0079610718300798.

142 See: H.J. Melosh, 'Exchange of meteorites (and life?) between stellar systems', Astrobiology, Spring 2003;3(1):207-15, https://pubmed.ncbi.nlm.nih.gov/12804373/; Eva Botkin-Kowacki, 'Did life on Earth come from space? Chummy microbes offer clues'

www.csmonitor.com/Science/2020/0826/Did-life-on-Earth-come-from-space-Chummy-microbes-offer-clues. See also: Michael Marshall, 'Panspermia' www.newscientist.com/term/panspermia/\#ixzz6dZZRx7g6/.

143 See: F.H.C. Crick and L.E. Orgel, 'Directed panspermia' Icarus (Volume 19, Issue 3, July 1973) www.sciencedirect.com/science/article/pii/0019103573901103.

144 See: 'With New Theory of the Cambrian Explosion, Scientists Reach (Literally) for the Stars' (25 th May 2018) https://evolutionnews.org/2018/05/with-new-theory-of-the-cambrian-explosion-scientists-reach-literally-forthe-stars/.

145 Dartnell, ‘(Un)welcome Visitors', 33.

146 May, Astrobiology, 44.

147 Krauss, The Physics of Star Trek, 83.

148 Davies, The Eerie Silence, 151. 


\title{
Theofilos
}

A Nordic open access journal in Theology, Philosophy and Culture

Published by NLA University College - in partnership with Johannelund School of Theology

Available at www.theofilos.no

\section{'Unraveling the Mystery' Assessing The Big Bang Theory as a Secular Fictional Universe ${ }^{1}$}

\author{
Margunn Serigstad Dahle \\ Associate Professor in Communication and Worldviews \\ NLA University College \\ Ingvild Thu Kro \\ Assistant Professor in Communication and Worldviews \\ NLA University College
}

\begin{abstract}
This essay seeks to meet the need for identifying and responding to secular worldview perspectives in popular culture from a Christian apologetic perspective. The focus in this case is on naturalism, scientism, and anti-religious attitudes, with the highly popular sitcom The Big Bang Theory (season 11) as a case study. The methodological approach is a content analysis with worldview theory as the hermeneutical perspective. The findings of the analysis suggest that naturalism and weak scientism seem to be the underlying worldview perspectives in The Big Bang Theory. Supernatural beliefs are rejected as irrational, but despite that the overall trust is in science, there are moments where other sources of truth and meaning seem to be given credibility. From these conclusions we identify both points of contact and points of tension to Christian faith, representing both opportunities and challenges for Christian cultural apologetics, both in relation to science and religious faith as well as the relation between them.
\end{abstract}

Keywords: Popular culture, worldviews, The Big Bang Theory, naturalism, scientism, cultural apologetics

\section{Introduction}

'The characters ... are so funny (in part) due to their extremely "scientistic" worldviews, entirely framed by their practice of science. The humor manifests as their scientific approach unfolds in everyday life.'

- Massimo Pigliucci²

The quote above is an excerpt from a philosophical analysis of The L Big Bang Theory. It illustrates the key role of secular worldviews in the flow of the story in this highly popular sitcom. According to Massimo Pigliucci, it is not just the characters' nerdy personalities that make the audience laugh, but even more how they illustrate what clinging to a secular worldview - such as scientism looks like. ${ }^{3}$ This indicates that secular worldviews are influential in the fictional universe of this sitcom.

The Big Bang Theory serves as a significant example of how traces of secular worldviews, such as naturalism and 
scientism, often are found in popular movies, television series and other fictional stories. This points to the need for Christian cultural apologists to analyse the key role of secular worldviews in contemporary popular culture and to offer a relevant response. Thus, The Big Bang Theory is a natural choice as a case study in relation to 'Science, Natural Theology, and Christian Apologetics'. ${ }^{4}$

Nigerian author Ben Okri points out that '[stories] are the secret reservoir of values. Change the stories individuals and nations live by and tell themselves, and you change the individuals and nations'. ${ }^{5}$ Furthermore, when considering how common secular perspectives in popular fictional stories often seem to correspond to influential secular presuppositions in many Western academic and educational contexts, the cultural apologetic task turns out to be even more significant. When faced by the same underpinning secular worldviews in both contexts, the need for double listening becomes obvious. ${ }^{6}$ This task includes uncovering traces of such worldviews in these influential cultural texts as well as formulating a normative response based on appropriate biblical texts.

Many of the background beliefs that our Western culture presses on us regarding Christianity, often making the Christian faith seem implausible, are being presented through the stories and themes of entertainment and social media rather than by argument. 'They are assumed to be simply the way things are', as Timothy Keller points out. Furthermore, according to Keller, most of these stories are secular or relativistic. ${ }^{7}$

Thus, a key task for contemporary Christian cultural apologists is to uncover and challenge secular values and beliefs, such as naturalism, existentialism, and secular humanism, in popular culture as well as in academic and educational contexts. For Christian youth, such secular stories often create a deep feeling of cognitive dissonance in relation to their personal Christian convictions, ${ }^{8}$ which is yet another key reason for analysing and evaluating the different perspectives from a biblical perspective.

In this essay, then, we seek to meet the need for identifying and responding to secular worldview perspectives in popular culture from a Christian apologetic perspective, with the highly popular sitcom The Big Bang Theory as a case study. This sitcom, with a total of 12 seasons ending in May 2019, has a wide spectrum in terms of its audience, both regarding age ${ }^{9}$ and country. We have chosen season 11 as our research material, due to this season being the latest published in DVD format at the time of starting our research. ${ }^{10}$ Building on key findings from earlier research on previous seasons, we will be focussing on traces of naturalism, scientism and anti-religious attitudes.

This leads to the following two research questions:

1. How are naturalism, scientism and anti-religious attitudes being expressed and portrayed in season 11 of The Big Bang Theory?

2. What opportunities and challenges do these secular beliefs, ideas and motifs represent for Christian cultural apologetics?

In order to answer these two research questions, the article contains three major sections.

The first major part of the article introduces some foundational theoretical perspectives on worldview theory and popular culture, on sitcoms in general and The 
Big Bang Theory specifically, on naturalism, scientism, and anti-religious attitudes, and on Christian apologetics. This leads to an outline of the methodological approach for content analysis with worldview theory as the hermeneutical perspective.

The second major section of the article contains a worldview analysis of the selected season of The Big Bang Theory.

The third major part of the article presents a normative response to the series from a Christian cultural apologetic perspective, before concluding with summary and reflections.

\section{Foundational Theoretical Perspectives}

\section{Worldview Theory and Popular Culture}

The term worldview can be understood in different ways. This article is informed by the concept of worldview proposed by Naugle (2002) and developed and applied by Sire: ${ }^{11}$

A worldview is a commitment, a fundamental orientation of the heart, that can be expressed as a story or in a set of presuppositions (assumptions which may be true, partially true or entirely false) which we hold (consciously or subconsciously, consistently or inconsistently) about the basic constitution of reality, and that provides the foundations on which we live and move and have our being. (Sire $2015,141)^{12}$

The emphasis on 'commitment' and 'a fundamental orientation of the heart' indicates that everyone has a worldview, whether religious or secular in its foundational convictions. Furthermore, this understanding of how worldviews are often grasped as stories, not only as rational propositions, is, of course, highly relevant to the worldview analysis of fictional, visual universes and to the whole process of meaning-making. As will be shown below, Sire's worldview concept opens constructive avenues of explorations and has proved to be very fruitful when developing a toolbox for content analysis of media messages. ${ }^{13}$

In a media-saturated culture like ours, it is vital to relate to the stories from the perspective of what's being communicated. The influence of the stories of popular culture can hardly be overstated. Popular culture may be defined by being commercial and known, liked and used by 'the masses', as well as being aimed at offering entertainment and distraction from everyday life (Endsjø and Lied 2011, 16). But, although it is aimed at entertainment, the implicit and explicit messages are not neutral, but convey a wide spectrum of different perspectives, values, and beliefs.

As Philip Pullman stated in his Carnegie Medal acceptance speech:

All stories teach, whether the storyteller intends them to or not. They teach the world we create. They teach the morality we live by. They teach it much more effectively than moral precepts and instructions. ${ }^{14}$

This means that popular culture is ' $\mathrm{a}$ place of debate and negotiation, it gives us examples of how our contemporaries are thinking' (Turner 2013, 23). Therefore, popular culture is a useful indicator of the Zeitgest, the 'spirit of the times'. It both mirrors and moulds our way of thinking and living, express pointers to different worldviews and plays a key role in the worldview formation of young people. ${ }^{15}$

Stories, then, are powerful, whether 
fictional or factual. Because of popular culture and the popular media's vast impact in our culture, we ought to pay close attention to what is portrayed, when it comes to values and preferences, truth and reality. After all, as Walt Mueller claims about today's youth: 'They are being catechized through regularity and repetition into a series of cultural beliefs that result in behaviors ... now and for the rest of their lives.'16 The stories of popular culture, which are 'known by the masses', is therefore a natural starting point when reflecting on underlying perspectives, including views on (natural) science and religious beliefs.

\section{Popular Culture, Sitcoms and The Big Bang Theory}

Among the variety of media stories in popular culture, the sitcom proves to be highly popular. The term is short for situation comedy, and the genre is marked by how it centers around a story that unfolds from episode to episode, where we follow a set of characters over time and in their mutual environment, like a home, workplace or a circle of friends. The term sitcom can be traced to the 1950 s, first in radio and then in television. Originally the sitcom was organized in individual episodes, where the storytelling largely was static, and the characters barely changed over time. In more recent decades, however, the sitcom has increasingly been characterized by a coherent and recurrent storytelling that may well last over a whole season, where both the story and the characters can change and develop over time. ${ }^{17}$

A helpful description of sitcoms is 'realistic fiction' (cp. Tony Watkins 201018), meaning that the storytelling and the characters resemble real life, in so far as the viewer can relate to events and situations that are portrayed. But at the same time, it is fiction, simply because it is not realistic since the sitcom has a tendency so exaggerate, both related to the events, the characters and the humoristic elements.

David Lodge describes sitcoms as 'light, family entertainment, which aims to amuse and divert the viewers, not to disturb and upset them.'19 Lewis and Molloy expand on this, stating that 'the comedy reveals a culture's viewpoint through the lens of laughter' $(2015,90)$. Verbal humour is one of the most important features of sitcoms, often initiated and enforced by a laughter-track or live studio audience. The poet T.S. Elliot was convinced that the culture we consume just for fun, with no thought of grappling with heavyweight issues, has an enduring effect on us. He believed this was true precisely because of the fun element. ${ }^{20}$

Comedians recognize the power of laughter and how laughter can make it easier to portray themes or views the audience normally would reject or be offended by. As the American stand-up comedian and social critic George Carlin says, 'Once you get people laughing, they're listening, and you can tell them almost anything'.21

Carlin expanded on this idea in an interview:

Most of the time, when you talk to people about, let's call them 'issues,' okay? People have their defences up. They are going to defend their point of view, the thing they're used to, the ideas that they hold dear, and you have to take a long, logical route to get through to them, generally ... But when you are doing comedy or humour, people are open, and when the moment of laughter comes, their guard is down, so new data can be introduced more easily at that moment. ${ }^{22}$ 
The Big Bang Theory is most definitely a sitcom that makes people laugh, all over the world, 'using satire, comedy, intertextual references and even burlesque to offer its perspective on the "geeky" world of brilliant scientists (and their friends)' (Lewis and Molloy 2015, 89).

The Big Bang Theory has been one of the early 21 st century's most popular TV series worldwide. ${ }^{23}$ Created by the renowned directors Chuck Lorre and Bill $\mathrm{Prady}^{24}$, the series premiered on CBS in USA September 24, 2007, and concluded on May 16, 2019, having broadcast a total of 279 episodes over 12 seasons. ${ }^{25}$ In Norway, the TV series played its final season during the spring of 2019 , and in both USA and Norway the sitcom continues to play in reruns.

'The Big Bang Theory has been the defining comedy of its generation,' Kelly Kahl, President for CBS Entertainment, said in a statement as the decision to end the show was announced. ${ }^{26}$ Furthermore, the huge popularity and influence of the series is seen in the decision to produce the spin-off series Young Sheldon, where viewers follow the major character Sheldon from The Big Bang Theory as a young boy living in Texas with his family. In February 2019, CBS renewed this series for a third and fourth season, with the third season running in USA during the autumn and spring of 2019/2020.27

Set in Pasadena, California, The Big Bang Theory has a focus on science and scientists, particularly physics and physicists. The four main male characters, theoretical physicist Sheldon Cooper (Jim Parsons), experimental physicist Leonard Hofstadter (Johnny Galecki), aerospace engineer Howard Wolowitz (Simon Helberg), and astrophysicist Rajesh (Raj) Koothrappali (Kunal Nayyar) are all employed at Caltech (California Institute of
Technology). The same is true for Sheldon's girlfriend (and later wife), neurobiologist Amy Farrah Fowler (Mayim Bialik), and Howard's wife (his girlfriend in the early seasons) microbiologist Bernadette Rostenkowski (Melissa Rauch). The characters frequently banter about scientific theories or news and make science-related jokes. These intellectual nerds (as they are portrayed) have their humoristic counterpart in the beautiful and street-smart Penny (Kaley Cuoco). In contrast to all the other characters, her and her father's last name is never revealed. Penny dreams of being an actor and is now married to Leonard, being his girlfriend in the early seasons. Stuart Bloom (Kevin Sussman), the owner of a comic bookstore, is also a recurrent character.

Co-director Chuck Lorre explains what they intended with the series:

From the very beginning, the goal was really simple: to cause laughter. That's why we made the show and why we wanted to build a show around these characters. I love the characters because, despite how intelligent they were, they felt left out. They felt like outsiders looking through the glass at life going on without them ... The characters aren't related but they behave and operate like a family even to the point of making each other miserable. But no matter what, they created a surrogate family. That underlies the comedy and may ultimately be more important than the jokes. ${ }^{28}$

It is interesting to observe that over recent years there has been a shift in certain themes and characters portrayed in sitcoms, one of them being the portrayal of nerds. In fact, The Big Bang Theory is reckoned as the most widely known, and popular, television program currently supporting this trend. ${ }^{29}$ 


\section{Key Aspects of Naturalism, Scientism and Anti-Religious Attitudes}

Key findings in earlier research on The Big Bang Theory, whether from a rhetorical, a philosophical, or from a worldview perspective, pointed to dominant traces of naturalism, scientism and anti-religious attitudes. ${ }^{30}$ As for the latter, these attitudes primarily relate to the Jewish and the Christian faiths. When analysing season 11 , we will have the same focus. In the following, we will outline key aspects related to these three thematic areas.

In relation to naturalism, the term in short denotes a worldview or belief system which denies the supernatural. Naturalists tend to 'view supernaturalism as clinging to non-scientific, non-empirical justifications for beliefs, the opposite of objectivity' (Carlson 2017, 469).

Since the Enlightenment, naturalism has been a powerful influence in the academy as well as gradually also in popular Western culture, and now increasingly also globally. It emerges in different configurations, and carries different labels, such as scientism, secular humanism, and Marxism, but with a common underpinning notion of the denial of the supernatural. The cosmos is seen as being ultimately one thing; matter, existing as a uniformity of cause and effect in a closed system.

Human beings are therefore seen as only being part of the natural cosmos. Our uniqueness is accounted for in different ways by different strands of naturalism. Physicist Sean Carrol, in his bestselling book The Big Picture, explains the naturalistic view of humans in this way:

We humans are blobs of organized mud, which through the impersonal workings of nature's patterns have developed the capacity to contemplate and cherish and engage with the intimidating complexity of the world around us... The meaning we find in life is not transcendent... ${ }^{31}$

Furthermore, while naturalists must include human actions within their causally closed view of physical events in the universe, some hold that this 'determinism' is consistent with a non-libertarian, 'compatibilist' understanding of human freedom.

As indicated above, naturalism is still an attractive worldview for many, despite being challenged both by secular alternatives (such as postmodernism) and by religious worldviews. At least two primary reasons may be given for why naturalism continues to be influential. It gives the impression of being a worldview that is honest and objective, and which has a consistent, coherent system.

Furthermore, as stated earlier, the naturalistic worldview accommodates different variations on the naturalistic theme - for instance Marxism and secular humanism - and is thus more widespread than one might think in the first place. Even though the latter form of humanism is completely framed within a naturalistic view of reality, not all naturalists are secular humanists. But all secular humanists are naturalists when it comes to the fundamental view of reality. Due to the emphasis in secular humanism on human dignity, freedom and reasoning, this fact is easily overlooked. ${ }^{32}$

What, then, about scientism? In the first place it is helpful to distinguish between 'strong' and 'weak' scientism.

Strong scientism claims that some proposition is true and / or rational to believe if and only if it is a scientific proposition ... There are no truths apart from scientific truths, and even if there were, there would be no reason whatever to believe them. 
Advocates of weak scientism allow for truths apart from science... But those advocates still hold that science is the most authoritative sector of human learning. Every other intellectual activity is inferior to science. Further, there are virtually no limits to science. (Moreland 2017, 629)

Accordingly, scientism may appropriately be described as:

the idea that science can and should be expanded to every domain of human knowledge or interest, including the social sciences and the humanities, or alternatively the idea that the only kind of knowledge really worth having is that provided by the natural sciences (Pigliucci 2012, 131).33

Anti-religious attitudes appear in very different modes and shapes. It covers a wide spectrum, from various intellectual, moral, and social objections to Judeo-Christian beliefs, through popular myths and misconceptions, to hostility, indifference, and political correctness. It has been pointed out that The Big Bang Theory often conveys religion in general as oldfashioned and fundamentalist, whereas Christianity specifically is largely presented as 'a "god-of-the-gaps" approach' to reality (Barkman and Kowalski 2012, 150).

At the plausibility level, anti-religious ideas contribute to the marginalization of Christian beliefs, institutions and practices. This illustrates that 'central areas of modern society are secularised and secular outlooks on life are highly influential' (L. Dahle, 2015, 387). Thus, Christian ideas appear as less meaningful and Christian institutions and practices as more marginal.

Many influential media stories include popular stereotypes and myths about the
Christian faith, where anti-religious attitudes often are predominant. 'This includes popular fictional stories where secular worldview perspectives are portrayed positively, Christians are being stereotyped, and Christian faith and practices are excluded.' (L. Dahle, 2018, 142)

\section{Introducing Christian Apologetics}

Christian apologetics focuses traditionally on defending and commending the biblical Gospel. Thus, the emphasis is both on justifying key Christian truth claims and on communicating the Christian worldview as authentic and relevant in secular and pluralistic contexts.

An influential definition of Christian apologetics is offered by William Lane Craig in his classic textbook Reasonable Faith:

Apologetics specifically serves to show to unbelievers the truth of the Christian faith, to confirm that faith to believers, and to reveal and explore the connections between Christian doctrine and other truths... [It is] the broader task of Christian apologetics to help create and sustain a cultural milieu in which the gospel can be heard as an intellectually viable option for thinking men and women. (Craig 2008, 15, 17)

When using the term Christian apologetics in this article, we are focusing on 'the art of apologetics'. ${ }^{34}$ This is closely linked to the notion of 'cultural apologetics', highlighting that our understanding of apologetics needs to incorporate the concepts of beauty and goodness as well as the concept of truth, together with a holistic understanding of humanity. As Joseph Woodell argues:

Apologetics is the task of helping people see not only the truthfulness, but also the attractiveness of 
the Christian faith... Christianity is true, for it corresponds to reality; but being true, it is also both (morally) good and (aesthetically) beautiful... Adding aesthetics to the apologetic toolbox can only help the apologetic enterprise. ${ }^{35}$

Accordingly, theological aesthetics will be central to our approach in this article. This growing thematic field is concerned 'with questions about God and issues in theology in the light of and perceived through sense knowledge (sensation, feeling, imagination) through beauty, and the arts' (Thiessen 2004,1). We will return to these key issues in our apologetic response to The Big Bang Theory below.

\section{Introducing the Methodological Approach}

The selected methodological approach in this essay is content analysis informed by worldview theory, already applied by us in previous studies. ${ }^{36}$ As stated above, the term worldview is here understood in line with David Naugle's proposal, and as developed and applied by James W. Sire.

Our starting point is that all media messages may be seen as texts, whether verbal, audial or visual. These texts provide 'scripts' or 'templates' that model the way life is, or should be' (Turnau 2012, 27). In order to identify these 'scripts' or 'templates' - and thus analyse media messages from a worldview perspective - we use a methodology developed by Margunn S. Dahle which consists of four interlocking levels. ${ }^{37}$

The first two levels belong to the preparatory stage. At the emotional level the focus is on the emotional response that is created by the media message, whereas the aesthetic level means looking at the dramaturgical and artistic elements in the media message; the plot, music, editing, acting and so on. After all, in the words of David Porter, in any visual media message 'more is said than what is spoken' (1988, 15).

The third phase is the worldview level, which is the focal point of the analytical framework. This level 'combines the identification of key worldview elements and traces of influential worldview traditions and trends' (M.S. Dahle 2017, 64).

The first step at this level is to identify key characteristics of the observable praxis in the fictional universe, such as behaviour and conversation, through a focus on plot, character and dialogue. Building on David Howell's insights regarding worldview formation, where 'Self', 'Peers', 'World' and 'Beyond' are key areas around which the worldview is being developed, sustained or changed (Howell 1997), it has proved to be useful to categorize the observable praxis in this way. Thus, paying attention to 'what is being said and done' related to oneself ('Self') and friends / family ('Peers'), and to the relationships to authorities and the wider society ('world'), as well as to the future and beyond ('Beyond').

The second step at the worldview level is to identify key worldview elements in the observable praxis, such as foundational views of ethical values, humanity, reality and faith (defined as trust and search for meaning). These traces of worldviews, then, are sought to be matched with different worldview patterns, both religious and secular.

Thus, by focusing on the observable praxis within the categories of 'Self', 'Peers', 'World' and 'Beyond' in selected scenes in season 11, we will seek to identify how the traces of naturalism, scientism and anti-religious attitudes function in the flow of the story. The key findings will be compared to what Kro identified 
when analysing season 6,38 before widening the perspective to the whole television series when reflecting on our own findings as well as on those identified by other researchers.

The fourth level is the normative. This constitutes the follow-up stage, where the aim is to give a 'relevant Christian response, critically asking whether the identified worldview elements are consistent with a biblically informed Christian worldview' (M.S. Dahle 2017, 64), including pointing to elements of contact and elements of tension. Thus, the normative level moves on from worldview analysis to theological engagement, which will be further explained below, when dealing with the apologetic response to key findings in The Big Bang Theory.

\section{Analysis of The Big Bang Theory, Season 11: The Worldview Level}

It is appropriate to offer three preliminary remarks before applying a worldview analysis (i.e. the third analytical phase introduced above) to season 11 of The Big Bang Theory.

First, our remarks and reflections above, on sitcoms in general and The Big Bang Theory specifically, serve as pointers towards the first and second analytical phase, i.e. the emotional and aesthetical levels. The sitcom genre relies heavily on emotional communication with the TV audience, especially in this case in its conscious use of humour, irony and satire. Aesthetically, this sitcom has a coherent and recurrent storytelling over the whole season, where both the story and the characters change and develop over time.

Secondly, our worldview analysis of selected scenes in season 11 builds on our long-term engagement with and assessment of the whole TV series. This leads to some final overall reflections on this fictional universe as a totality.

Thirdly, before the analysis of season 11 , an introductory analysis of the opening theme used throughout The Big Bang Theory seems to be a natural starting point. The opening theme - or the title theme - has a key role in establishing a show's unifying identity as well as in aiming towards capturing and keeping the attention of the audience.

\section{Key findings related to the theme song}

The opening theme song was ranked sixth out of ten popular credit sequences in 2010.39 The aesthetics are captivating, with the visual as well as the music catching the attention of the audience. The images, visualizing the lyrics of the song performed by The Barenaked Ladies, make the impact even larger, despite a very high speed.

The actual lyrics runs as follows:

Our whole universe
was in a hot, dense state
Then nearly 14 billion years
ago expansion started Wait!
The Earth began to cool
The autotrophs began to drool,
Neanderthals developed tools
We built the Wall
We built the pyramids
Math, Science, History,
unraveling the mystery
That all started with a big bang
Bang!

This title theme song is written by Ed Robertson, a member of the band The Barenaked Ladies. 40

The opening theme sequence points to different fields of human enquiry and academic study. Whereas the reference to Big Bang belongs to cosmology, evolution is part of biology, and the focus on human achievements is related to history. The underlying unifying perspective is 
secular, with no ultimate references to any gods or God. The view of history, as well as of humanity, is marked by optimism, which indicates a positive view also of the future. Thus, when relating to the category 'Beyond', we identify clear pointers to a secular, naturalistic worldview. Human progress is highlighted, with science and technology as authorities to the extent that it points towards scientism. Thus, the category 'World' points to secular perspectives. As the final line fades out, the main characters in the show sit down on a sofa, smiling and eating, obviously having a good time. 'Self' and 'Peers' get the final note.

Within the framework of the lyrics and all the different images underlining this secular view of cosmology, evolution and human progress, one gets the impression that the characters are part of a long line of progress, and therefore the future is bright. Further, the image of the group points to a close friendship, which seem to indicate the need for fellowship as well as a view of humanity as superior within nature. Thus, the key beliefs and ideas underpinning the theme song are interconnected and fit into a secular worldview perspective, and at the same time its ending seems to illustrate a tension between a naturalistic view of reality and a secular humanistic view of humanity.

It should also be mentioned, that whenever there is a shift of scenes in an episode, a certain part of the intro, where molecules are being displaying, is shown. In this way, the viewers are constantly reminded of the theme song, the focus on natural science, and the pointers towards a naturalistic worldview.

\section{The Big Bang Theory: A brief intro- duction to season 11}

Season 11, the second to last season of
The Big Bang Theory, ran in the USA during the fall and spring of 2017/2018,41 and marked the ten-year anniversary of the show. During season 11, Howard and Bernadette, in addition to Penny and Leonard, are married, whilst Raj is still single, searching for true love. In the first episode of this season, Sheldon proposes to Amy, and one main storyline throughout the season is their engagement, culminating in the wedding as the season's end.

Howard and Bernadette have their second baby during this season. Although we never see the children, their struggles related to pregnancy, parenting and family life are central to the storyline. Penny and Leonard wonder whether they should 'take the next step' too. Thus, a running theme in the whole season is linked to such family issues, as well as the relationship between family life and careers.

Career as an independent theme is also highlighted, not the least with Leonard and Sheldon who are questioning the foundations and trustworthiness of their choices of science. However, after a period of wondering if 'supersymmetry' 42 really is the answer to the mysteries of the universe, Sheldon has a flash of inspiration and excitedly work on a new theory of 'super asymmetry', seemingly restoring everyone's faith in science again.

\section{Key findings in The Big Bang Theory, season 11}

\section{Key findings related to 'Self' and 'Peers'}

In a sitcom like The Big Bang Theory, with the story unfolding around a group of close friends and colleagues, the most natural move is to begin the analysis by focusing on the part of the storyline dealing with different aspects regarding their relationships to themselves, each other and their families. 
However, their families are not visible as family units in the series. This is also true of this season. ${ }^{43}$ On the contrary, this group of friends acts as a surrogate family. This makes it even more interesting to ask oneself in what ways traces of naturalism, scientism and anti-religious attitudes may be identified in this category of 'Self' and 'Peers' in their observable praxis in season 11.

As well as being key to the flow of the storyline, the dialogues between the characters are vital when it comes to identifying pointers to their views of themselves, and of love, life, and what it means being human. In this season, with Bernadette being pregnant and primarily out of work, we get glimpses of her view of selfidentity and self-esteem. She used to think of herself as a smart, educated, and successful woman, whereas now she is bewildered. The way she and Amy talk about the change, is purely naturalistic, referring to changes in the structure of the brain. 'I liked the old structure of my brain. But then, I liked a lot of my old structures', Bernadette replies to Amy's explanations. 44

This conversation moves towards a conclusion which is meant to be of comfort to Bernadette, with Amy referring to the many positive changes in the structure of the brain brought about by the pregnancy. Still, Bernadette is not satisfied, accusing her friend for being condescending. Taking the naturalistic worldview perspective to be the only explanation for the changes, even though also some of the changes in the brain structures are positive, doesn't seem to be satisfying when it comes to her view of self-identity and selfesteem. Taking into consideration that career and image seem to play a key role regarding her self-identity and selfesteem, Bernadette finds herself in a vul- nerable situation.

Raj seems to be just as dissatisfied when it comes to love being explained in - or reduced to - naturalistic terms. When a colleague says: 'Raj, we're scientists. We don't need to feel threatened just because we understand the mechanisms that give rise to romantic feelings. It doesn't take anything away from the experience.', 45 Raj couldn't disagree more, being convinced that love isn't science, but 'an acknowledgement of a mystery that's greater than ourselves'. Thus, he shows dissatisfaction regarding a naturalistic perspective when it comes to this part of life. Raj seems to long for a more coherent worldview where experience and explanation of love fit together.

Not surprisingly, love is central in many conversations in this season, with Amy and Sheldon being engaged, planning for their wedding. Emotions aren't that important to Sheldon, though, and he's willing to put aside the thought of upsetting anyone and leave emotions totally aside when deciding who are to be invited for the wedding based on empirical metrics only. The reason being that in his view people are at a wedding to perform specific functions. An underlying perspective here seems to be an ignorance of emotions and a stress on reason. Again, this can be seen as a pointer towards Sheldon taking the naturalistic worldview at face value, whereas Amy seems to be dissatisfied about the split that is being revealed in a naturalistic worldview. ${ }^{46}$ Like Bernadette and Raj, whom we referred to above, Amy seems to long for a more coherent worldview.

The strong emphasis on reason is of course very much in line with their work as scientists. The view of reason as the defining aspect of a human being is a recurrent theme in the conversations, 
alongside the fear of not being in total control. As an example, Sheldon is very worried about his sleep-talk and whether or not he can fully trust his mind.

Furthermore, their identity seems to be anchored in reason and the ability to do science, thus viewing physics as 'the real thing'. After Leonard had been totally honest in a radio interview about their struggles in their research, Leonard and Sheldon are close to an identity crisis. ${ }^{47}$ 'Physics is all we're cut out for', Leonard states, and continues: 'I mean, if we weren't physicists, what would we be?' Sheldon underlines that nothing can be compared to physics, since physics 'answers the question: what is the nature of the universe?'

Underneath, there seems to be a longing for anchoring the identity in something different from their career. Amid this crisis, they turn to Penny, who is the only one in the group of friends not working with science. The reason being, as stated to her by Sheldon: 'You manage to hold your head high, despite your checkered past.' 48

\section{Key findings related to 'World'}

In The Big Bang Theory as a whole, natural sciences seems to be an undisputable source of facts and truth about reality as a whole. Science seems to be regarded as honest, objective and coherent. The validity of other theories or sciences are determined by whether they coincide with the natural sciences, or more specifically with physics. Even the title of the TV series and its theme song, as pointed out earlier in this analysis, clearly points to the natural sciences as indisputable and sufficient explanations of reality.

The naturalistic view of reality is being conveyed in different ways throughout the series. One example is when Raj says the following (when presenting a virtual tour among the stars at the planetarium); 'Space is the mirror of the soul. Are we looking beyond, or are we looking within? ... When we gaze out at the immensities of space, we understand them because there are immensities within us as well.'49 One may interpret his statement either as a reflection of Raj's Hindu background 50 or as a naturalistic view, the latter being the most plausible due to what's being portrayed in the series as a whole. In other words, just as the universe is nothing more than nature, which is made up by matter, and nothing exists outside this nature to uphold it, so human beings are also nothing more than products of nature, like any other animal.

The same basic beliefs seem to be prominent with Sheldon, who acts as the foremost champion of faith in natural science and its undisputable truths. During season 11 though, he finds himself surprisingly interested in geology, although with mixed emotions:

I am a respected theoretical physicist. I aspire to win a Nobel Prize someday. But nobody's gonna take me seriously if they find out I've been dabbling in geology ... They're very different. Physics answers the question: what is the nature of the universe? Geology answers the question: what'd I just trip over?51

Here Sheldon, despite a transitory interest in geology, seems to make a clear distinction between different natural sciences, some of them being more significant than others. In his view, physics is the 'real science', it is where you would go to find the 'real' answers. This implies that, according to Sheldon, geology cannot answer any of the fundamental questions to the origin of the universe, its purpose 
or meaning. In other words, physics is being asserted as an undeniable authority, not only for the whole of reality, but also within the field of natural sciences. It is physics, Sheldon claims, not geology, which answers the fundamental questions for understanding reality - and ultimately the meaning of life.

This view of science, seemingly providing meaning even to the most mundane business, also comes across during Sheldon and Amy's planning of their wedding. Being unable to choose their maid of honour and best man, they decide to use science to solve their problems, and thus also leaving feelings (from both sides) aside. A choice Sheldon is very happy with this:

\section{Boy, if I had known getting married was going to involve so much science, I'd have proposed years ago ... If experimenting on humans is morally wrong, then I don't want to be mo- rally right. 52}

In this regard, science (if taken at face value) seems to a be source of excitement and joy and, in addition, an over-all source of meaning. This is where the characters trust to find the best answers, and ultimately the truth. It also surpasses the value of human beings (if they have a specific value) and of morality (if there ever was such a thing).

Although the entire season 11 (and the entire TV series) points to trusting the natural sciences for ultimate truth and meaning, there are also glimpses of how this naturalistic foundation is cracking. In season 11 we find Leonard as a guest on a radio show. When he is asked about his profession as an experimental physicist, he reveals that although millions are being spent on expensive research projects, the different projects aren't producing any final results or answers to the ultimate questions about the universe. As Leonard is saying 'We've been collecting tons of data that could revolutionize the way we understand the universe'53, but he must admit that the data is not giving them the final answers they are looking for. When the radio presenter then asks what they actually have found, Leonard replies:

Uh, nothing, actually ... But I re-
main confident. We've got the best
equipment and the best minds all
working on it ... Although, some
days I'm, like, ugh, we've spent so
much money. Why haven't we
found anything? What are we
doing?54

In this scene Leonard apparently doubts his profession and whether he contributes significantly to the wider society. This is ultimately enhanced when he turns to Sheldon for encouragement;

Sheldon: 'Look. (sighs) Not all science pans out. You know, we've been hoping supersymmetry was true for decades, and finally, we built the Large Hadron Collider, which is supposed to prove it by finding these new particles, and it-it hasn't. And maybe supersymmetry, our last big idea, is simply wrong.' Penny: 'Okay. So, you guys are upset because the collider thing disproved your theories?'

Leonard: 'I-It's worse than that. It hasn't found anything in years, so we don't know if we're right, we don't know if we're wrong. We don't know where to go next.' 55

This appears to be an unexpected turn of events in the context of the entire TV series. The undisputable trust in the natural sciences (and especially physics) to be the ultimate source of truth about reality and meaning runs throughout every season of the series, almost never questioned, 
or challenged. It is highly interesting, therefore, that here in season 11 this seemingly ultimate trust in the natural sciences as the foundation of authority seems to crack, at least slightly. This seems to shake the characters, so that they even consider changing their career paths or research areas, and they also seem to some extent to question the foundations of their naturalistic worldview. They seemingly admit that although natural science has given answers to lots of mysteries in the universe, it might not - or cannot - give the answers to everything.

This state of mind seems to affect the characters for parts of this season. Even Sheldon, though he is not questioning natural sciences as such, seems to question to what extent theoretical physics really can provide him with the ultimate answers he is searching for. Hence his 'dabbling in geology'. However, in the final episode of the season, while Sheldon and Amy are getting ready for their wedding, he and the other scientists seemingly have their 'faith' in natural sciences restored:

Sheldon: 'My equations have been trying to describe an imperfect world, and the only way to do that is to introduce imperfection into the underlying theory.'

Amy: 'So, instead of supersymmetry, it would be super asymmetry?' Sheldon: '(Gasps) Super asymmetry. That's it! ... So, if I make slightly asymmetric knots with sheets in four dimensions, I can bootstrap the whole idea to a large asymmetry in 11 dimensions.'

Amy: 'Maybe even at the initial moment of creation, the fundamental forces lacked symmetry.'

In the end, the TV series provides no conclusion to the deep questions and sincere doubts expressed by the characters when facing the limitations of the natural sciences. Instead, the faith in science seems to be restored, and the scientists embark on a new path towards a theory they hope will give the answers to the functions and foundations of the natural universe. In other words, a naturalistic worldview seems still to have a stronghold as an ultimate authority.

The key findings related to 'the World' in season 11 confirms the overall impression of the whole series, when it comes to a deeply rooted trust in natural science as an objective, reliable and ultimate source of truth. This deep trust is somewhat shaken when Leonard admits that science has not been able to produce the desired answers to the ultimate questions about the universe, leading several of the characters to question their career paths. At the end of the season however, this trust, and everyone's 'status quo', is seemingly restored, and the questions of the ultimate reliability and possible weaknesses of the natural sciences remains unanswered. This leaves the overall impression that the natural sciences still is the most trustworthy foundation for understanding reality.

\section{Key findings related to 'the Beyond'}

As we saw earlier, 'the Beyond' relates to views on and attitudes towards the future and the religious. The major focus in this section will be on the latter part; i.e. views and attitudes in season 11 of The Big Bang Theory towards religion and expressions of religious faith in general, and towards Christian faith especially.

But first, some reflections on views of the future in this TV series. This can be understood in a threefold way; the future of the universe, humanity, and the individual (or personal) future. The view of the future of both humanity and the uni- 
verse seem to be dominantly positive. As pointed out in relation to the theme song, and as generally confirmed in the entire storyline, the view of history and human beings are marked by fundamental optimism. The general development of society, largely due to the influence of natural science, is bringing us forward and making us more enlightened.

When it comes to the individual, personal future, the focus is the here and now, in so far as there seems to be no purpose or meaning inherent in the future, which in any way would or should affect the life here and now. On the other hand, what was identified in relation to naturalism and the natural sciences as authorities, or more specifically, the events that lead especially Sheldon and Leonard to doubt the foundations of their science and ultimately their career paths, has underlying implications for their view of their future. They seem to ask questions about how and if they can succeed as scientists in the future, and whether their science will bring any meaningful contributions to the wider society. But, as their faith in science is restored when they discover the possibility of a theory of super asymmetry, their faith in and positive view on the future is seemingly restored accordingly. ${ }^{56}$

It should be noted that religion is portrayed mainly in relation to the religious backgrounds of the major characters. Howard is Jewish, married to Bernadette who is Catholic. Raj has a Hindu background. Sheldon grew up with his mother, Mary, in a devout evangelical Christian home. All the characters except Mary have seemingly left their religious faith, but the religious backgrounds are still expressed in different ways throughout the storyline. 57

When it comes to views on various religious aspects and on religion in general, this is not a dominant theme in The Big Bang Theory. But in contrast to many other popular contemporary TV series, religion and religious aspects are portrayed and discussed explicitly. The clear overall impression, when taken at face value, is that traditional religion is devalued, whether through Howard's syncretistic, subjective attitude towards his Judaism or through Sheldon's condescending interaction with his mom's conservative evangelical Christian beliefs. From a rhetorical analytical perspective, one could claim that the TV series presents a mixed attitude, sometimes critical and sometimes somewhat respectful, toward religion (Lewis and Molloy, 2015:88). But the underlying strong naturalism seems to deride religious faith of any credibility or objectivity, as 'clinging to non-scientific, nonempirical justifications of beliefs' (Carlson, 2017). The series clearly portray a wide gap, and even a clear contradiction, between religion (including the Christian faith) and science.

It is interesting that this negative portrayal, almost without exception, is aimed at theistic religions, and more specifically Judaism and Christian faith. ${ }^{58}$ Expressions and beliefs from Judaism is mainly connected with Howard. In earlier seasons Howard expressed a subjective Jewish faith, detached from the Jewish tradition and dogmatic content (Kro 2014). In season 11, Howard's connection to Jewish faith only comes across in religious rhetoric used to underline humorous points, like: 'Well, these hands were made to do three things: close-up magic, writing code, and the dirty shadow puppet show that got me kicked out of Hebrew school.'59 or 'Don't care. Clean slate. Happy Yom Kippur to me.'60 Or when Penny suggest names for their new 
baby: 'You know, I always thought Christian was a nice name', and Howard responds: 'I don't know. Sounds a little too uncircumcised.' 61 The comic frame of Howard's religious rhetoric partially seems to be observance of Jewish rituals and religious holidays and is central to the playful irony in Howard's Jewish identity. Thus, this reflects his Jewish background, but does not indicate that he has any personal commitment to the Jewish faith. In other words, 'Howard's religion rests primarily on cultural identification rather than personal practice'. (Lewis and Molloy 2015, 95)

When it comes to portrayals of religion and views on religion or religious faith, the religion with the most focus is undoubtedly Christianity. Even though Sheldon in season 11 seems to have an overall softer attitude towards his Christian mother than in previous seasons, his resistance towards religious beliefs in general, and Christian beliefs especially, continues. It is also in connection with Sheldon's relationship with his mother that the views and attitudes towards religion as a whole - and Christian faith specifically - are most clearly expressed, and where the alleged contradictions between Christian faith and science are expressed.

Sheldon's mother, Mary, who is a devout, evangelical Christian, comes across as loving and caring, but at the same time, in contrast to the young scientists, she appears as an unintelligent creationist and traditionalist, who reads her Bible literally. (Lewis and Molloy 2015, 93). Undoubtedly, Sheldon loves his mother, but he clearly rejects her religious faith, as expressed already in the first episode of season 11:

Sheldon: 'Mother, I have some good news to share.'

Amy: '[giddily] We're engaged!'

Mary Cooper: 'I am so happy for you two, but I'm not surprised.

I've been praying for this.'

Sheldon: 'Well, God had nothing to do with it. It happened because I was kissing another woman, and it made me realize I wanted to be with Amy.'

Mary Cooper: 'More than one woman was interested in you? I might have prayed a little too hard.'

Sheldon: 'I want to let you know right now that we are not getting married in a church.'

Mary Cooper: 'That's all right, Sheldon. Anywhere Jesus is, is a church.'

Sheldon: 'Well, he won't be at our wedding.'

Mary Cooper: 'He's in my heart, so if I'm there, he'll be there.'

Sheldon: 'Okay, well, then he's your plus-one. You don't get to bring anyone else.'

Mary Cooper: 'That's fine. Love you.'

Sheldon: 'Love you, too. Bye.'

Mary Cooper: '[They hang up]

Lord, thank you. Even though you can do anything, that was mighty impressive.' 62

The conversation, although the satirical and comical are prevalent, shows the tension between Sheldon and his mother's faith. Mary brought Jesus and prayer into the dialogue, and Sheldon didn't like it, clearly illustrating Sheldon and his mother's different convictions and perceptions. As illustrated here, prayer seems to be a recurrent theme of tension, colliding with Sheldon's naturalistic view of reality, where miracles or any other divine intervention in our world is out of the question. The same conclusion seems to be the case when it comes to the presence of something divine:

Mark Hamill: 'We are gathered here today in the sight of family, friends and Almighty God.' 
Sheldon: 'That's too religious.'

Mark Hamill: 'That lady over

there made me say it.'

Sheldon's mother: 'He heard you, and he can't un-hear you.'63

Both here, and in the previous scene, God is almost portrayed as a 'God of surveillance'. The omniscient God, who in Mary's eyes watches over his creation, but in Sheldon's perspective seems - if he was real - to intrude in his private life.

Sheldon also seems to make fun of his mother's Christian belief, comparing it to something as mundane and shallow as a profile in social media; 'My mother is pushing for my brother, Georgie, to be my best man, and I hate to disappoint her again. I already rejected her Saviour and her LinkedIn invitation.' 64

While religion or religious beliefs are constantly challenged or made fun of, the natural sciences are never object to the same kind of critical treatment. The overall impression is that there is a stark contradiction between science and religious faith, exemplified through the tension between Sheldon's natural science as a theoretical physicist and his mother's conservative, tradition-bound Christianity.

In conclusion, religion and religious aspects may not be among the most frequent themes highlighted in The Big Bang Theory, but the fact that religion and religious aspects are portrayed to the extent they are, makes the series stand out. Whether it is Howards Jewish identity, Sheldon's evangelical, Christian upbringing, or Raj's Hindu background, the way The Big Bang Theory 'enjoy making fun of the characters and their active or indifferent attitudes toward religion and spirituality, there is no particularly evident malice toward any specific faith or belief system.' (Lewis and Molloy 2015, 99). At the same time, the way religion is viewed as irrelevant and only appealing to the apparently ignorant and simple-minded, like Mary, religion and religious faith nevertheless seem to have low credibility and consequently cannot be a believable source for trust or truth about reality (Kro 2014, 56). The Big Bang Theory may not devalue religious human beings, when showing the characters' religious affiliations, but the series clearly devalues religion as a source of ultimate truth and meaning. The Big Bang Theory seems to convey an overall belief in the natural sciences as an indisputable and ultimate source of truth and thus as the only credible view of reality, while at the same time excluding any notion of a supernatural divinity. Thus, religion and religious beliefs have no ultimate authority and no credible grasp of reality.

\section{Analysis of The Big Bang Theory, Season 11: The Normative Level}

\section{Foundational Theological Aesthetical Concerns}

In this follow-up phase, we offer a normative theological perspective, where points of contact and points of tension are identified, and a tentative apologetic response to these is formulated.

In line with previous research, our discussion will be informed by the following foundational theological aesthetical concerns:

(a) Movie as a contemporary art form reflects the dual nature of humanity, both as gloriously made in the image of God and as being guilty sinners.

(b) Movies are significant listening posts in the art of double listening, which provides us with key insights about the human dilemma and about influential 
worldview messages.

(c) The consumption of movies has a key role in worldview formation across generations but seems potentially to have a special influence on children and youth, thus providing us with a special window into significant meaning-making processes through visual storytelling and interpretation. (M.S. Dahle 2019, 15-29)

As mentioned earlier, the art of double listening to the Word and the world was formulated as a missional concept by evangelical theologian John Stott. He advised Christian preachers and communicators 'to see some of the most notable films and plays, since nothing mirrors contemporary society more faithfully than the stage and the screen' (1982, 193).

The Big Bang Theory is undoubtedly a highly significant contemporary television series, also in view of the worldview messages communicated in and through this fictional universe. The opportunities and challenges represented by these worldview messages need to be taken seriously by Christian theologians, communicators, and apologists.

\section{Apologetic Tasks: Exploring Key Points of Contact}

Despite its dominant secular worldview messages, The Big Bang Theory includes some implicit pointers to Christian truth. The deep fascination in the series with science and technology points to structure and order in the universe, which - according to Christian apologetics - is explained most satisfactorily by a Christian natural theology. Furthermore, the key role of humour in the TV series points to some uniquely human features, as a signpost to humanity created in the image of God.

Such key points of contact may be seen as 'signals of transcendence', to use Peter Berger's rich term. These signals include 'such typical human experiences as hope, play, humour, order and judgment' (Guinness 2015, 142). They are
phenomena that are to be found within the domain of our 'natural' reality but that appear to point be- yond that reality ... In short, a sig- nal of transcendence points beyond one belief and points toward anoth- er belief - or at the very least, it points towards what might be true or would have to be true if the sig- nal's pointing is to have any satisfac- tory ending. (Guinness 2015, 134)

It is the calling of the Christian apologist to trigger these signals by helping people 'to hear, to listen and to understand those signals, and then to help them follow to where they lead'. (Guinness 2015, 147). Thus, exploring 'play, humour, [and] order' in the fictional universe of The Big Bang Theory, as well as Sheldon's and Leonard's doubts about natural sciences as the ultimate source and answer, could lead towards a gradual discovery of credible and attractive arguments and stories found in natural theology and Christian apologetics.

Furthermore, although Sheldon's mother Mary is treated by his son as a fundamentalist traditionalist, she comes across as a humble person, always wanting 'to give Jesus credit'. She is transparent and open in talking about her Christian faith, and she is always ready to defend it. Even though she comes across as naïve and clearly is the Christian 'fool bearer' (Guinness 2015, 67f) in the series, she is nevertheless portrayed as being personally authentic in her beliefs. As viewers, we might even get some sympathy for Mary and her beliefs, thus beginning to wonder whether her son could be unfair in his 
unrelenting critique of her traditional Christian faith. If so, a classical Christian faith might be well worth exploring.

\section{Apologetic Tasks: Exploring Key Points of Tension}

The analysis above has identified the secular worldview perspectives of naturalism and scientism as being dominant in this season of the TV series. However, '[through] the lens of The Big Bang Theory, we can see how attempts to develop a thoroughgoing scientistic worldview are bound to fail, calling for more balanced approaches to understanding the world around us' (Pigliucci 2012, 129)

Exploring such points of tension illustrates the apologetic approach called 'turning the tables', in this case showing how naturalism and scientism fail. This strategy 'turns on the fact that all arguments cut both ways. It therefore proceeds by taking people seriously in terms of what they believe and disbelieve, and then pushing them towards the consequences of their unbelief'. (Guinness 2015: 109) This includes challenging 'scientistic believers' 'whether they can know enough science to tear the mask off nature and stare at the face of God.' (Kowalski 2012, 2)

This apologetic approach of 'turning the tables' is an illustration of 'the fool maker' (Guinness 2015:72f), where the naturalist and the scientist are shown to be 'fools proper' (Guinness 2015:66f). If so, there is no fundamental contradiction between the natural sciences and the Christian faith. On the contrary, Christians would argue that the natural sciences - ultimately - only make sense within a traditional Christian worldview with a belief in a personal Creator, having created nature as ordered and intelligible and human beings in His image as rational, curious, and creative. ${ }^{65}$

Furthermore, Christians would argue that biblical natural theology and Christian apologetics contain coherent and credible arguments for the central truth claims of a Christian worldview. Thus, the portrayal in this humorous fictional universe of Sheldon's Christian mother Mary as naïve and superstitious, may illustrate widespread secular prejudices about Christians, but has no bearing on the actual intellectual foundations of the Christian faith. Such challenges to secular prejudices about Christianity, may open exciting avenues of fruitful exploration of central Christian truth claims. 66

\section{Conclusions}

\section{Answering the Research Questions}

1. How are naturalism, scientism, and anti-religious attitudes being expressed and portrayed in season 11 in The Big Bang Theory?

We may now briefly summarize the findings of our worldview analysis above.

The first overall impression is that this season is characterized by naturalism and strong scientism. Any supernatural beliefs are rejected as superstitious and science seems to be the only valid source of truth and meaning. When we look closer, however, naturalism and weak scientism seem to be the underlying worldview perspectives. Supernatural beliefs are rejected as irrational, but although the overall trust is in science, there are moments where other sources of truth and meaning seem to be given credibility. Like when Raj reflects that love is not science, but ' $a$ mystery that's greater than ourselves'. Or when Sheldon and Leonard doubt the foundations of their science and they wonder whether answers must be found 
elsewhere. But as the overall storyline show, they still hold science as the most authoritative source of truth and meaning, as do advocates of weak scientism.

The creative use of humour, irony, and satire at times weakens the overall portrayal of naturalism, scientism, and antireligious attitudes as the dominant worldview messages in The Big Bang Theory. Nevertheless, it could be argued that these secular worldviews messages probably remain in the viewers' perceptions as defining ultimate truth and meaning for the major character in this TV series, and therefore may be considered as attractive secular worldview alternatives for the viewers themselves.

2. What opportunities and challenges do these secular beliefs, ideas, and motifs represent for Christian cultural apologetics?

We may now briefly summarize key opportunities and challenges. Regarding points of tension, it is important to bear in mind that even though they present challenges in the first place, a challenge can be turned into an opportunity.

The main challenge is the strong view of contradiction between science and religion in general and Christian faith in particular. Religion is viewed as a matter of blind beliefs, whereas science is viewed as being based on facts. Thus, only scientists have a proper foundation for knowledge and truth, contrary to religious people who are superstitious and simple minded, believing in myths and fairy tales. A consequence of this is that only scientific explanations are viewed as reliable, which then leads to reductionism and fragmentation.

As pointed out in our analysis, most of the characters seem to struggle with this fragmentation on different levels and areas of life. This then illustrates how a challenge to Christian faith can be turned into an opportunity for Christians to demonstrate a coherent worldview. From there, one may be given an opportunity to acknowledge the truths of science, as well as identifying its limitations. Furthermore, opportunities may be given to make obvious that science also carries with it an element of faith, and thus is not neutral.

The most obvious point of contact is found in the fact that there is actually a structured and orderly universe to be explored. From a biblical viewpoint the reason is found in God, the Creator. Further, need for fellowship, love, care, encouragement and affirmation, as well the dissatisfaction regarding science' lack of fulfilling the need for coherence that is being portrayed in The Big Bang Theory serve as key points of contact.

Regarding portrayal of Christian faith in The Big Bang Theory, Sheldon's mother has the courage to proclaim her faith, even though she comes across as quite naive. From an apologetic perspective this serves as an opportunity for inviting people to explore what Christianity is all about, and also challenges the notion of privatizing one's faith.

\section{So What? Some Final Reflections on Key Cultural Apologetic Tasks}

The Big Bang Theory 'reveals a creative interpretation of the culture of scientific nerds and geeks as well as culture perspectives (including religion) of a vast majority of viewers of the show.' (Lewis and Molloy 2015, 91). Maybe it is true that The Big Bang Theory mirrors the majority of the viewers' perspectives and attitudes towards culture, including science and religion. However (as pointed out earlier), popular culture, including The Big Bang Theory, not only mirrors, but also 
moulds the viewers perspectives and attitudes, including towards the issues highlighted here. That clearly shows us that popular culture plays a key role in the worldview formation of young people, and therefore challenges Christians to reflect on popular culture as a key apologetic task, with a view towards identifying both opportunities and challenges for communicating Christian faith to young people today.

The strong belief in science we have seen in The Big Bang Theory conveys both an opportunity and a challenge for Christian cultural apologetics, when it comes to the foundations of faith, truth, and the view of reality as a whole. In viewing the sort of faith conveyed in science in The Big Bang Theory, one could describe this as 'functional religiosity', meaning that the foundations are secular, but the functions are virtually religious. This provides the characters with a shared frame of reference for their worldview, where natural sciences and naturalistic perspectives guide their view of reality, human beings, and values. This aspect also demonstrates the notion that everyone has a worldview, and for some that worldview is so firmly rooted in naturalistic notions that they resemble a religious faith, but with a secular foundation. This could be an opportunity for Christian cultural apologetics to disclose the popular notion that religion equals blind faith and science equals facts.

When this essay was published, The Big Bang Theory had finished their last season. The series continues to be popular through replays and streaming, and the secular perspectives of the series remains influential in popular culture. This is illustrated by the popular spin-off series Young Sheldon, with a storyline focussing on Sheldon's childhood, and with the same overall secular perspectives and attitudes as The Big Bang Theory.

\section{Reference bibliography}

Barkman, Adam and Dean A. Kowalski (2012). 'Cooper Considerations: Science, Religion, and Family', in Dean A. Kowalski (ed.), The Big Bang Theory and Philosophy (Hoboken, NJ: John Wiley \& Sons), 144-158.

Carlson, Richard F. (2017). 'Naturalism'. In: Paul Copan et al. (eds.) Dictionary of Christianity and Science: The Definitive Reference for the Intersection of Christian Faith and Contemporary Science (Grand Rapids, MI: Zondervan), 469-470. [Kindle]

Cooper, W. Jeff (2014). 'Stereotypes in Television and Film: The Impact of the Big Bang Theory'. In: Jack Korpob Pongpunya and Laurel Dreher (eds.) NASPA Men and Masculinity, Fall Newsletter, 8-10.

https://www.naspa.org/images/uploads/events/MM_Newsletter_FALL2014.pdf\#page=8.

Dahle, Lars (2015). 'Western Europe - Marginalisation of Christians through

Secularisation?’. In: Hans Aage Gravaas et al. (eds.), Freedom of Belief \& Christian Mission. (Oxford: Regnum Books), 382-394.

http://www.ocms.ac.uk/regnum/downloads/Freedom_of_Belief_and_Christian_MissionFinal-WM.pdf (retrieved 12 $2^{\text {th }}$ Oct. 2019).

Dahle, Lars (2018). 'Cognitive Dissonance as a Missiological Challenge: An Evangelical Perspective on Western Europe’. In: Marina Ngursangzeli Behera et al. (eds.) 
Mission in Secularised Contexts of Europe: Contemporary Narratives and Experiences. (Oxford: Regnum Books), 137-149.

Dahle, Margunn Serigstad (2010), Kap. 4. Filmanalyse som ressurs for trosopplæreren. In: Margunn Serigstad Dahle and Lena Skattum (eds.) Manus for livet? Film som verktøy for trosopplaeringen (Oslo / Kristiansand: IKO-forlaget / Damaris Norge), 68-98.

Dahle, Margunn Serigstad (2017). 'Worldview Formation and the Disney Universe: A Case-Study on Media Engagement in Youth Ministry'. Journal of Youth and Theology, 16 (1), 60-80. [https://brill.com/view/journals/jyt/16/1/article-p60_5.xml]

Dahle, Margunn Serigstad (2019). 'Story and Meaning-Making: A Multilevel Approach to Film in Faith Education'. In: Anita Cloete (ed.), Interdisciplinary Reflections on the Interplay between Religion, Film and Youth. (Stellenbosch, South Africa: African Sun Media), 17-32.

Dahle, Margunn Serigstad and Bjørn Hinderaker (2020). 'Livssynsteori som perspektiv ved NLA Mediehøgskolen Gimlekollen'. In: Hagesæther, G., Innerdal, G. \& Kvam, B. (eds), NLA Høgskolen. Fagutvikling og sjølvforståing på kristen grunn. (Oslo: Cappelen Damm Akademisk); 147-185. [https://doi.org/10.23865/noasp.102]

Dahle, Margunn Serigstad and Ingvild Thu Kro (2013). 'Hotell Caesar sett med norsksomaliske øyne - om populærkultur og verdiformidling’. In: Økland, Øyvind (ed), Innvandrerungdom og mediebruk: Norsk-somalisk ungdom i en global medieverden. (Kristiansand: Portal forlag), 36-56

Dahle, Margunn Serigstad and Ingvild Thu Kro (2018). 'Disney som danningsagent. Med Frost og Jake og sjørøverne i Drømmeland som case’. In: Nyjordet, Bjørg Marit (red), Barns mediehverdag (Oslo: Cappelen Damm Akademisk), 24-42.

Endsjø, Dag Øistein and Liv Ingeborg Lied (2011). Det folk vil ha. Religion og popularkultur. (Oslo: Universitetsforlaget).

Guinness, Os (2015). Fool's Talk: Recovering the Art of Christian Persuasion (Downerss Grove, Ill.: IVP Books).

Howell, David (1997). 'Youth Culture and World View', Whitefield Briefing 2 (6): 1-4. Oxford: The Whitefield Institute.

https://static1.squarespace.com/static/5c9e3e63e8ba4496c1df9458/t/5caf9425104c7be64 475611e/1555010598135/2.6+WB+Howell.pdf (retrieved 12 ${ }^{\text {th }}$ Oct. 2019).

Keller, Tim (2016). Making Sense of God: An Invitation to the Sceptical (New York: Penguin Publishing Group [Kindle Edition]).

Kro, Ingvild Thu (2014). Bare underholdning - eller? En analyse av den aktuelle tv-serien The Big Bang Theory. [Rapport] NKF / Damaris Norge

https://nkf.folkehogskole.no/app/uploads/2020/06/Bare-underholdning-eller.-Del-1-analyse-av-aktuell-tvserie.pdf (retrieved $16^{\text {th }}$ Nov. 2020).

Lewis, Todd V. and K. Arianna Molloy (2015). 'Religious Rhetoric and Satire:

Investigating the Comic and Burlesque Frames Within The Big Bang Theory'. Journal of Media and Religion 14 (2), 88-101.

https://www.tandfonline.com/doi/abs/10.1080/15348423.2015.1051457

(retrieved 12th Oct. 2019)

Lennox, John (2009). God's Undertaker: Has Science Buried God? [2 ${ }^{\text {nd }}$ ed.]

(Oxford: Lion Books). 
Lennox, John (2011) Seven Days That Divide the World: The Beginning According to Genesis and Science (Grand Rapids, MI: Zondervan).

Lennox, John (2019). Can Science Explain Everything? [The Oxford Apologetics Series] (Epsom, Surrey: The Good Book Company).

McGrath, Alister E. (1992). Bridge-building: Effective Christian Apologetics (Leicester: Inter-Varsity Press).

McGrath, Alister E. (2012). Mere Apologetics: How to Help Seekers \& Sceptics Find Faith (Grand Rapids; MI: Baker Books).

McGrath, Alister E. (2019). The Territories of Human Reason. Science and Theology in an Age of Multiple Rationalities [Ian Ramsey Centre Studies in Science and Religion] (Oxford: Oxford University Press).

Mills, Brett (2005) Television Sitcom. (London: British Film Institute Publishing)

Moreland, J. P. (2017). 'Scientism'. In: Paul Copan et al. (eds.) Dictionary of Christianity and Science: The Definitive Reference for the Intersection of Christian Faith and Contemporary Science (Grand Rapids, MI: Zondervan), 621. [Kindle]

Naugle, David (2002). Worldview: The History of a Concept. Grand Rapids: Eerdmans.

Pigliucci, Massimo (2012). 'The One Paradigm to Rule Them All: Scientism and The Big Bang Theory', in Dean A. Kowalski (ed.), The Big Bang Theory and Philosophy (Hoboken, NJ: John Wiley \& Sons), 128-143.

Porter, David. (1988) Users Guide to the Media. (Leicester: Inter-Varsity Press).

Richardson, Robin and Berenice Miles (2003). Equality Stories. Recognition, respect and raising achievement. (Stoke on Trent: Trentham Books).

Sire, James W. (2009). The Universe Next Door: A Basic Worldview Catalog. [5th ed.]

(Downers Grove, Ill.: InterVarsity Press.

Sire, James W. (2015). Naming the Elephant: Worldview as a Concept. [2nd ed.]

(Downers Grove, Ill.: InterVarsity Press.) [Kindle].

Stott, John (1992). The Contemporary Christian: An urgent plea for double listening.

(Leicester: Inter-Varity Press).

Thiessen, G. E. (ed.) 2004. Theological Aesthetics: A Reader (Grand Rapids: Eerdmans).

Turnau, Ted (2012). Popologetics: Popular Culture in Christian Perspective

(Phillipsburg, NJ: P \& R Publishing).

Turner, Steve (2013). Popcultured: Thinking Christianly About Style, Media, and

Entertainment (Leicester: IVP Books).

Williams, Peter S. (2019) 'The Apologetics of Cultural Re-Enchantment in 3D: A Review Essay of Fujimura's Culture Care \& Gould's Cultural Apologetics'. Theofilos 11 (1), 79-88. 


\section{Notes}

1 The expression 'unraveling the mystery' is from the opening theme song of The Big Bang Theory. It was also used in the title 'Unraveling the Mystery: A Big Bang Farewell', 'a retrospective special episode of the twelfth season ... aired on May 16, 2019, following the series finale.'

(https://bigbangtheory.fandom.com/wiki/Unraveling_the_Mystery:_A_Big_Bang_Farewell;

retrieved $12^{\text {th }}$ Oct. 2019)

2 The quote is from Pigliucci 2012, 128.

3 See further Pigliucci 2012, $128 \mathrm{ff}$.

4 'Science, Natural Theology, and Christian Apologetics' is the overall theme for this supplementary issue of Theofilos.

5 Quoted in Richardson, R. and B. Miles (2003), 1.

6 'We listen to the Word with humble reverence, anxious to understand it, and resolved to believe and obey what we come to understand. We listen to the world with critical alertness, anxious to understand it too, and resolved not necessarily to believe and obey it, but to sympathize with it and seek grace to discover how the gospel relates to it.' (Stott 1992, 28)

7 See Keller 2016, 5-6.

8 See L. Dahle 2018.

9 Viewership for The Big Bang Theory has been ranged from 14+ (https://www.commonsensemedia.org/ tvreviews/the-big-bang-theory; retrieved 12 ${ }^{\text {th }}$ Oct. 2019). Statistics from 2018 show that among youth and adults ranging 18-54, about half of the people interviewed watched the series 'sometimes' or 'daily/weekly'. In other words, the series is popular among adults as well:

(https://www.statista.com/statistics/876495/big-bangtheory-viewership-age/; retrieved $12^{\text {th }}$ Oct. 2019).

10 At the time of writing, season 12 aired on American and Norwegian television channels, but not streamed in Norway.

11 See M. S. Dahle and B. Hinderaker 2020.

12 This definition is a development of Naugle's proposal that a proper understanding of worldview must include the intellectual ideas (the content), the spiritual-moral dimensions (the heart) and the semiotic signs (the carriers of meaning). (See further the analysis and summary of Naugle's worldview concept in Sire 2015, 46-55.)

13 See further M. S. Dahle 2010 and M. S. Dahle 2019.

14 The whole speech is found at https://djamesauthor.blogspot.com/2013/10/philip-pullmans-carnegiemedal.html (retrieved $12^{\text {th }}$ Oct. 2019).

15 See further M. S. Dahle 2017 og M. S. Dahle 2019.

16 In a blog post at https://cpyu.org/2018/03/08/a-passionate-appeal-to-parents (retrieved 12 ${ }^{\text {th }}$ Oct. 2019).

17 Some of the most well-known examples are Friends (1994-2004), How I Met Your Mother (2005-2014) and Modern Family (2009- ), in addition to The Big Bang Theory (2007-2019).

18 In a blog post 'Why bother with soap?' http://www.tonywatkins.co.uk/media/television/why-bother-withsoap/ (Published 2010, $3^{\text {rd }}$ Sept.2010).

19 Quoted in Mills 2015:1. According to Brett Mills, theories about humour have traditionally been spilt into three camps; superiority, incongruity and relief, even though the three categories overlap, with varying degrees of relevance to media communication. Furthermore, Mills points out that many analyses place the humour of sitcoms within the category of superior theory. Here humour arises from attaining a position of 'sudden glory', in which laughter reinforces positions and is inevitably defines as a negative social phenomenon. In this way the jokes of sitcoms have been seen to confirm hegemonic ideologies. (See Mills 2015, 90)

20 See Turner 2013, 15.

21 Quoted in Turner 2013, 16.

22 'Paradigm Shift Interview' by Philip H. Farber; (retrieved 29th May 2019).

23 An illustrating example is the 2017-2018 season, where The Big Bang Theory was the most watched TV series in US with an average of 18.634 million viewers, only beaten by NBC's NFL Sunday Night Football. (See https://deadline.com/2018/05/2017-2018-tv-series-ratings-rankings-full-list-of-shows-1202395851/ ; retrieved $12^{\text {th }}$ Oct. 2019.)

24 Lorre and Prady serve as executive producers for The Big Bang Theory, along with Steven Molaro and Steve Holland. We should also note the well-known series Dharma \& Greg (with both Lorre and Prady), Two and a Half Men (with Lorre) and Gilmore Girls (with Prady).

25 See further https://en.wikipedia.org/wiki/The_Big_Bang_Theory and https://bigbangtheory.fandom.com/wiki/Main_Page.

26 See https://tvline.com/2018/08/22/the-big-bang-teory-ending-season-12-final-episode/.

27 'Young Sheldon' is one of the most-watched shows on broadcast and the second most-wached comedy, behind only 'Big Bang.' https://variety.com/2019/tv/news/young-sheldon-renewed-season-3-4-cbs-1203146124/ (retrieved $12^{\text {th }}$ Oct 2019). 
28 https://www.hollywoodreporter.com/live-feed/big-bang-theory-series-finale-explained-chuck-lorre-how-itended-1211557 (published 16th May 2019; retrieved 25 th May 2019).

29 See further Cooper 2014.

30 See esp. Pigliucci 2012, Barkman and Kowalski 2012, Kro 2014, and Lewis and Molloy 2015.

31 Quoted in Lennox 2019, 18.

32 See esp. the discussion on naturalism, secular humanism and Marxism in Sire 2019, 66-93.

33 McGrath refers to philosopher Ian Kidd's insightful observation that 'three basic 'impulses' can be discerned as lying behind the rise of scientism: 1. An imperialist urge ..., 2. A salvific urge ... [and] 3. An absolutist urge ...' (McGrath 2019, 57)

34 'Christian apologetics is both a science and an art. It is an academic discipline, rigorously grounded in Christian theology, and passionately concerned to demonstrate and defend the truth of Christianity. But it is also a craft, a creative attempt to ensure that the gospel proclamation meshes as closely as possible with the needs and concerns of human existence.' (McGrath 1992, 265) Thus, whereas the science of apologetics is a branch of systematic theology, the art of apologetics is an integrated part of practical theology.

35 Quoted in Williams 2019, 79-80.

36 See M. S Dahle and I. T. Kro 2013, and M. S. Dahle and I. T. Kro 2018.

37 See M.S. Dahle 2010, M.S. Dahle 2017, and M.S. Dahle 2019.

38 See further Kro 2014.

39 See See https://bigbangtheory.fandom.com/wiki/The_Big_Bang_Theory (retrieved 12 ${ }^{\text {th }}$ Oct. 2019).

40 In writing this song, Robertson was influenced by Simon Singh's Big Bang: The Most Important Scientific Discovery of All Time and Why You Need to Know About It, often nicknamed 'The History of Everything'. The title theme is the first verse of a whole song.

See further https://www.songfacts.com/facts/barenakedladies/the-big-bang-theory (retrieved $12^{\text {th }}$ Oct. 2019).

41 In Norway the season aired a few months later, mainly during 2018.

42 Supersymmetry may be defined as 'a hypothetical symmetry among groups of particles containing fermions and bosons, especially in theories of gravity (supergravity) that unify electromagnetism, the weak force, and the strong force with gravity into a single unified force'

(https://www.dictionary.com/browse/supersymmetry ; retrieved $12^{\text {th }}$ Oct. 2019).

43 It should be mentioned that Sheldon's mother and brother, as well as Bernadette's father and Amy's parents, are part of this season, but - in line with this fictional universe as a whole - the family members are not being described as clear family units.

44 Episode 18: 'The Gates Excitation'.

45 Episode 9: 'The Bitcoin Entanglement'.

46 Episode 12: 'The Matrimonial Metric'.

47 Episode 18: 'The Retraction Reaction'

48 Episode 7: 'The Geology Methodology'. Here, her 'checkered past' means 'the ups and downs' of her past.

49 Episode 14: «The Separation Triangulation»

50 Throughout the series, Raj's Hindu background is seldom mentioned, and when it is, it is mainly as a cultural identification. Religious practices only come into play when it serves his best interests. (See also Lewis and Molloy 2015, 97.)

51 Episode 7: The Geology Methodology.

52 Episode 12: The Matrimonial Metric.

53 Episode 2: The Retraction Reaction.

54 Episode 2: The Retraction Reaction.

55 Episode 2: The Retraction Reaction.

56 Further on, related to aspects of the future, Howard and Bernadette's reflections around having another baby and managing family life, and Penny and Leonard talking about the possibility of having children, reveals aspects of the future, but with no clear links to this article's focus on naturalism or scientism, and will therefore not be explored any further here.

57 For Leonard, Penny and Amy, there are no clear pointers to any kind of religious upbringing. Their view on religion seems to be benign indifference, pointing towards more atheistic or agnostic upbringings, except for the times Penny reveals an openness to supernatural, more New Age-related experiences, such as psychics. 58 It is interesting to note that Islam is never mentioned, thus apparently not subject to the same kind of sceptical treatment as the other theistic religions.

59 Episode 5: 'The Collaboration Contamination'.

60 Episode 15: 'The Novelization Correlation'.

61 Episode 16: 'The Neonatal Nomenclature'.

62 Episode 1: 'The Proposal Proposal'. 
63 Episode 24: The Bou Tie Asymmetri.
64 Episode 12: The Matrimonial Metric.
65 See e.g. Lennox 2009, Lennox 2011, Lennox 2019, and McGrath 2019.
66 The first titles of the new popular-level Questioning Faith Series illustrate such fruitful explorations:
Can science explain everything? (John Lennox); Am I just my brain? (Sharon Dirckx); Is Jesus history?
(John Dickson); Why does God care who I sleep with? (Sam Allberry); and Where is God in all the suffering?
(Amy Orr-Ewing). (See further https://www.thegoodbook.com/series/questioning-faith/; retrieved 16 ${ }^{\text {th }}$ Nov.
2020.) 


\title{
Natural Theology and Science in Contemporary Apologetic Context: An Overview
}

\author{
Peter S. Williams \\ Assistant Professor in Communication and Worldviews \\ NLA University College, Kristiansand, Norway \\ peterswilliams@gmail.com
}

\begin{abstract}
This essay offers some context to this Supplement edition of Theofilos, which presents peer reviewed papers resulting from the 2018 NLA Gimlekollen Symposium on the theme of 'Science, Natural Theology, and Christian Apologetics'. I review something of the history of natural theology and of natural philosophy (i.e. science), discuss objections to natural theology from theological and philosophical critics, review some key developments within the field of natural theology (especially as it relates to science), and end with some advice on natural theology and Christian apologetics in an age of science.
\end{abstract}

Keywords: Natural Theology, Science, Apologetics, Philosophy, Spirituality

\section{Science, Natural Philosophy, and Natural Theology \\ In his 'Address to the Clergy', John Wesley (1703-1791) urged:}

Some knowledge of the sciences also, is ... expedient ... the knowledge of one ... is even necessary ... I mean logic. For what is this, if rightly understood, but the art of good sense, of apprehending things clearly, judging truly, and reasoning conclusively? What is it, viewed in another light, but the art of learning and teaching; whether by convincing or persuading? What is there, then, in the whole compass of science, to be desired in comparison of it? . . . Should not a

\begin{abstract}
Minister be acquainted too with at least the general grounds of natural philosophy? Is not this a great help to the accurate understanding of several passages of Scripture? Assisted by this, he may himself comprehend, and on proper occasions explain to others, how the invisible things of God are seen from the creation of the world; how 'the heavens declare the glory of God, and the firmament showeth his handiwork;' till they cry out, 'O Lord, how manifold are thy works! In wisdom hast thou made them all.' 1
\end{abstract}

To grasp the meaning of Wesley's advice, it helps to know that the Latin word scientia (from which we derive the word 
'science') simply meant 'knowledge'. For scholars from classical times until the nineteenth century, every academic discipline that laid claim to knowledge was by definition scientific. This included the sciences of theology ('the queen of sciences') and theology's 'handmaid' philosophy; the latter being a broad subject that included the sub-disciplines of rhetoric (and thus logic), natural philosophy (inquiry into the physical cosmos), and the making of arguments for God's existence (a discipline called natural theology).

Whilst the scriptures quoted by Wesley (Romans 1:18-20, Psalm 19) may be read as affirming that God can be intuitively perceived through contemplating creation, rather than as affirming that good arguments can be constructed linking creation to God (a matter of 'general revelation' rather than 'natural theology'2), they at least lay a foundation conducive to natural theology. Another scripture worth noting in this context is Paul's speech to the Lycaonians (Acts 14:15-17). ${ }^{3}$ As Norman L. Geisler writes: 'It should not seem strange to those who believe in God's manifestation in His creation (Rom. 1:19-29; Ps. 19:1) that it is possible to arrive at knowledge of God by inference from these manifestations.'4

\section{Natural Theology and Theology of Nature}

British scientist turned theologian Alister McGrath advocates a 'theology of nature' defined as 'a Christian understanding of the natural world that reflects the core assumptions of the Christian faith.' $5 \mathrm{He}$ explains:

The trajectory of thought here is from within the Christian tradition towards nature rather than from nature towards faith. This theology of nature is often expressed particularly in terms of the doctrine of creation ... The Christian faith is here understood to provide an interpretative framework by which nature may be seen in profound and significant ways ... like a lens bringing a vast landscape into sharp focus, or a map helping us grasp the features of the terrain around us. ${ }^{6}$

For McGrath, a 'theology of nature' isn't opposed to 'natural theology', but a way of approaching it:

The capacity of the Christian vision of reality to 'fit in' so much of what we see around us and experience within us ... can be seen as an indication of both its truth and its trustworthiness. Christianity makes sense of what we know about the history of the cosmos, especially the curious phenomenon of fine tuning. It helps make sense of the complexity of human nature, including our propensity to failure and self-delusion on the one hand and our genuine aspirations to goodness on the other. ${ }^{7}$

McGrath prefers this approach to natural theology over others because it's in sympathy with his preferred apologetic methodology: 'My approach is more like a scientist than a philosopher,'8 explains McGrath, 'I would describe my approach as 'inductive' or 'abductive' . . .'9 Indeed, McGrath extols 'a new style of natural theology adapted to the methods of natural science rather than conforming to the conventions of the philosophy of religion.'10 However, this latter distinction rests on a caricature of 'the philosophy of religion' as exclusively concerned with deductive arguments which claim 'to prove the existence of God'.11

On the one hand, contemporary philosophers of religion generally recognize 
that, in most contexts, including natural theology, there is no such thing as a rationally coercive argument. As Stephen T. Davis observes: 'few arguments are intellectually coercive ...'12 Indeed, Alvin Plantinga comments that:

A person might, when confronted with an argument he sees to be valid for a conclusion he deeply disbelieves from premises he knows to be true, give up (some of) those premises: in this way you can reduce someone from knowledge to ignorance by giving him an argument he sees to be valid from premises he knows to be true. ${ }^{13}$

In other words, the effectiveness of an argument is person-relative. ${ }^{14}$

On the other hand, natural theology has long incorporated arguments beyond the stereotypical 'proofs' of medieval scholasticism. For example, F.C. Copleston advanced a 'best explanation'15 argument from religious experience in his 1948 debate with Bertrand Russell. F.R. Tennant made a cumulative argument from 'cosmic teleology' in the second volume of his Philosophical Theology (Cambridge University Press, 1930).16 William Paley's famous 'watch-maker' argument from the early nineteenth century was framed as an inference (though it's often incorrectly portrayed as an argument by analogy). ${ }^{17}$ Blaise Pascal formulated an abductive version of the argument from desire in his seventeenth century Pensées. ${ }^{18}$. Even Thomas Aquinas' 'Five Ways' from Summa Theologica included an argument (i..e the 'fifth way') resting upon the inference that 'natural bodies, act for an end, and this is evident from their acting always, or nearly always, in the same way, so as to obtain the best result.'19

Moreover, twentieth century philoso- phers of religion explicitly imitated argumentative strategies from the natural sciences in natural theology. For example, Basil Mitchel used an analysis of scientific rationality in pursuit of The Justification of Religious Belief (Macmillan, 1973). Richard Swinburne's influential natural theology likewise takes its cues from scientific inferences and is famously structured using Bayes' probability theorem. ${ }^{20}$

In the final analysis, a preference for a given apologetic methodology cannot overrule the need to judge every purported argument for God on its individual merits, regardless of its logical form.

\section{Natural Theology Under Fire}

The project of natural theology, stretching at least as far back as the ancient Greeks ${ }^{21}$, came under fire in the early twentieth century from both within and without Christianity. 22

\section{Natural Theology Takes a Cold Bath}

In the theology of Karl Barth, not only was natural theology 'set against the revealed religion of Christ in Scripture' due in part to the former's historical linkage 'with German national Volk-religion', but 'biblical theology became isolated from rationality, presupposing its own truth ...23 Barth held that knowledge of God comes only through special revelation:

God in his sovereignty makes himself knowable. Man in his sinfulness cannot otherwise obtain any knowledge of God. A great gulf is fixed, bridged only by God in disclosing himself in Christ through the work of the Holy Spirit. Such knowledge is entirely a work of grace, unaided by human intellect. ${ }^{24}$

As Peter May goes on to explain, Barth:

did not believe in arguments or evidences to proclaim Christianity, 
and his influence persists strongly today. Such rational approaches to belief could in his view do nothing to facilitate a personal encounter with Christ. The evidence of nature and apologetic reasoning had no role in bringing people to faith. In his view, such rational thought could only be of benefit for those who already believed in God, and such belief could only come about by God's revelation of himself. ${ }^{25}$

As creator, God obviously takes the initiative in making himself knowable to humanity. However, to say that human (Godgiven) reasoning plays no role in bringing people to knowledge of or to faith in God/Christ, flies in the face of plentiful scriptural evidence to the contrary (e.g. Exodus 7:5; Ezekiel 25:11; John 14:11 \& 20:29-31; Acts 1:3, 2:1-42, 9:22, 14:1517 \& 17:30-31; Romans 1:17-19; 1 Peter $3: 15)^{26}$, as well as plentiful testimony from people whose belief in God and/or commitment to Christ was at least partially facilitated by Christian apologetics. ${ }^{27}$ As a case in point, I was delighted to receive an e-mail from Venezuela some years ago offering testimony that:

as a graduate student of philosophy, I'm a eager reader of your books and online articles, which have been instrumental in my rejection of agnosticism and naturalism and have contributed strongly to make me a new-born Christian.

\section{Once upon a time in Vienna}

There was a time, in the early twentieth century, when thinking about God was nearly banished from academia because of the many academics who thought that talk about 'God' was literally meaningless. They thought that 'God-talk' made no sense beyond its emotive content. 'God' wasn't the only subject to suffer such banishment. Assertions about right and wrong, beauty and ugliness - all statements that were metaphysical in nature - were widely considered to be literally nonsense.

The enforcer of this philosophical dress code was the now infamous 'verification principle' sponsored by a group of thinkers known as 'logical positivists'. Kelly James Clark explains that logical positivism: 'began in the early 1920s in an informal discussion group in Austria called the Vienna Circle. The original members, led by physicist Moritz Schlick, included mathematicians, physicists, sociologists and economists but no professional philosophers.'28 This omission was unfortunate, because: 'United by their passionate dislike of the metaphysical ... the group developed a unified philosophy that embraced science and attempted to destroy philosophy.'29 Attempting to develop a unified philosophy that dispenses with philosophy makes about as much sense as Groucho Marx's comment that he wouldn't belong to any club that would have him as a member. Nevertheless, the ideas of the Vienna Circle spread far and wide.

\section{The Circle of Exclusion}

Despite some disagreement among the members of the Vienna Circle, 'there was an initial impulse to accept the verification theory of meaning. . .'30 This theory held that any statement that wasn't true by definition (e.g. 'all bachelors are unmarried men') was only meaningful if it could be empirically verified (at least in principle). To 'empirically verify' something means to check it out with the physical senses (sight, hearing, touch, etc.), at least indirectly. In other words, the statement 'This is a book' is meaningful, because you can verify it by seeing, 
hearing, touching, smelling and/or tasting the book; but a statement like 'That sunset is beautiful' is not meaningful because you can't verify it's meaning by seeing, hearing, touching, smelling or tasting the 'beauty' of the sunset. Likewise, positivists hold that the statement 'God exists' cannot be verified and is therefore meaningless, a use of language on a par with nonsense poetry (like the parts of 'Jabberwocky' that Lewis Carroll didn't define ${ }^{31}$ ). It may have an emotional resonance, but it has no rational content that can be understood or judged as being an accurate or inaccurate representation of reality.

\section{The Influence of Language, Truth \& Logic}

The primary importer of logical positivism into Britain, and hence into AngloAmerican analytic philosophy, was A.J. Ayer (1910-1989). Unlike the members of the Vienna Circle, Alfred Jules Ayer (known to his friends as 'Freddie') was a philosopher. Ayer studied philosophy at Oxford under Gilbert Ryle before becoming a professor himself, ending up back at Oxford for a time (1947-59).

Ayer was immersed in logical positivism during 1932 whilst studying (at Ryle's recommendation) with Moritz Schlick in Vienna. This visit filled the gap between Ayer's university finals and taking up his first lectureship. Two years later, Ayer started work on the book that would make his name: Language, Truth \& Logic (1936):

Ayer's philosophical ideas were largely parasitic on those of the Vienna Circle. However, his clear, vibrant and (arguably) arrogant exposition of them makes Language, Truth and Logic essential reading on the tenets of logical positivism - the book is a classic and is widely read in philosophy courses around the world. ${ }^{32}$
Ayer proclaimed:

The term 'God' is a metaphysical term. And if 'God' is a metaphysical term, then it cannot even be probable that a god exists. For to say that 'God exists' is to make a metaphysical utterance which cannot be either true or false. . . If a putative proposition fails to satisfy [the verification] principle, and is not a tautology, then. . . it is metaphysical, and ... being metaphysical, it is neither true nor false but literally senseless. ${ }^{33}$

As Ayer admitted, positivism entailed that the denial of God's existence was just as meaningless as the affirmation of his existence, atheism as irrational as theism: 'If the assertion that there is a god is nonsensical, then the atheist's assertion that there is no god is equally non-sensical.' 34

Likewise, according to Ayer:

Such aesthetic words as 'beautiful' and 'hideous' are employed, not to make statements of fact, but simply to express certain feelings and evoke a certain response. It follows, as in ethics, that there is no sense in attributing objective validity to aesthetic judgements, and no possibility of arguing about questions of value in aesthetics ... there is nothing in aesthetics, any more than there is in ethics, to justify the view that it embodies a unique type of knowledge. It should now be clear that the only information which we can legitimately derive from the study of our aesthetic and moral experiences is information about our own mental and physical make-up. 35

Copleston noted that 'Ayer's writings exercised a widespread influence, particularly perhaps on university students, for whom it possessed the charm of novelty and an atmosphere of daring.' 36 Ayer's declaration that God-talk is nonsense has influenced generations of scholars, despite 
the fact that his book originally only sold 'just over 1,000 copies (64 years later, the book still sells 2,000 a year in Britain: a 1945 reprint in the United States has sold 300,000).'37 As Hilary Spurling observes:

It was one of those books that galvanize a whole generation. Ambitious undergraduates commonly read it at a sitting. Their elders were appalled. When students tried to discuss the book at an Oxford seminar, the Master of Balliol flung it through the window. Ayer was denounced by a housemaster at Winchester School as the wickedest man in Oxford. Asked what came next, the young iconoclast said cheerfully: 'There's no next. Philosophy has come to an end. Finished.'38

However, within a few of decades it became clear that philosophy had not come to an end and that positivism was 'finished', at least within academic philosophy. In 1943, E.L. Mascall observed that 'the logical positivists' position seems to be crumbling from within . . .'39 Two decades after Language, Truth and Logic was published, Copleston wrote: 'There are few British philosophers who willingly accept the title of 'positivists' or who make open profession of applying the principle of verifiability as a criterion of meaning . . . [Positivism] is no longer fashionable.'40 In The Cosmological Argument: A Reassessment (Charles C. Thomas, 1972), Bruce R. Reichenbach commented: 'The era is past when all metaphysical statements or arguments can simply be dismissed as silly or senseless, since they do not meet a pre-established criterion of verifiability.' 41 Despite being a dead issue in academic philosophy, the ghost of positivism continues to inspire uninformed attacks upon philosophy in general and natural theology in particular.

\section{A Negative Assessment of Positivism}

A number of factors explain the near total demise of positivism.

Ironically for materialists who embraced logical positivism, 'materialism would have to be rejected as nonsense by a strict interpretation of logical positivism'. ${ }^{42}$. The claim that matter is objectively real is, after all, neither true by definition nor something that can be verified by sense data (since it's the nature of what the senses perceive that's in question).

Indeed, positivism makes not only materialism, but also a realist account of science, impossible. As Copleston argued:

if the meaning of an existential proposition consists, according to the principle, in its verifiability, it is impossible, I think, to escape an infinite regress, since the verification will still itself need verification, and so on indefinitely. If this is so, then all [existential] propositions, including scientific ones, are meaningless. ${ }^{43}$

In an article published in 1960, philosopher John Hick pointed out that, when made precise enough, the statement that 'God exists' is, in principle at least, indirectly verifiable. Hick argued that:

A set of expectations based upon faith in the historic Jesus as the incarnation of God, and in his teaching as being divinely authoritative, could be so fully confirmed in postmortem experience as to leave no grounds for rational doubt as to the validity of that faith. ${ }^{44}$

If you were to die and then find yourself in a Christian afterlife - you are given a resurrected body and a life in a sinless community that revolves around the resurrected Jesus Christ - one could surely count this as an indirect verification of God's existence. Unless positivism is framed broadly enough to allow for indirect 
verification, many explanatory entities within science would count as nonsense, because they are verified indirectly. For example, scientific theories about so-called 'dark matter' would count as meaningless under a verification principle that excluded indirect verification. ${ }^{45}$ Again, just as empirical measurement of the background radiation of the universe provides indirect verification of the 'big bang' in cosmology (to see one isn't to see the other, but to see the one is to see something from which the other can be infer$\mathrm{red}^{46}$ ), so experiencing the sort of afterlife promised in the New Testament would likewise provide indirect empirical verification of God's existence. This being so, the claim that God exists is open to verification, in principle, and therefore counts as being a meaningful claim according to any principle of verification consistent with scientific practice.

In other words, the verification principle can't be used to wall off scientific claims about the universe from religious claims about its creator, because it either lets too much metaphysics or too little science into the category of 'claims that are meaningful'. As Llyod Eby observes: 'All attempts to solve this problem of having a version of the verification principle... that admits all scientific statements but excludes all metaphysical statements have met with failure.' ${ }^{47}$ Hence, as Hick concluded: 'the existence or non-existence of the God of the New Testament is a matter of fact, and claims as such eventual experiential verification.' 48

In 1967 American philosopher Alvin Plantinga published God and Other Minds, which 'applied the tools of analytic philosophy to questions in the Philosophy of Religion with an unprecedented rigour and creativity.' $49 \mathrm{He}$ argued by analogy with the rationality of belief in other minds (whose non-tautological existence can't be directly verified by empirical methods) that 'if my belief in other minds is rational, so is my belief in God.'50 But, of course, even verificationists generally believe in other minds.

Then, with the 1974 publication of The Nature of Necessity, Plantinga kickstarted a philosophical re-evaluation of theistic arguments by using modal logic to lay out a logically valid version of the ontological argument. ${ }^{51}$

Between them, God and Other Minds and The Nature of Necessity tackled both prongs of the positivist's proposed dilemma: Show that theism is either verifiable or tautologically true as a matter of definition, or else accept banishment to the outer darkness of meaninglessness. Plantinga responded to the first positivist prong that a demand for direct verification renders positivism self-contradictory, thereby opening up the possibility of arguments from indirect verification. To the second prong, Plantinga responded that, even if he can't prove that God's existence is tautologically true, he can prove that it is rational to think that God's existence is tautologically true, and that this fact is sufficient to demonstrate that God-talk is meaningful, for how can a truth-claim be rational without also being meaningful?

Exploiting the openings noted by Hick and Plantinga, philosophers such as Basil Mitchell and Richard Swinburne began to argue that the God hypothesis isn't merely indirectly verifiable in principle, but also in practice, since several arguments for God can be framed using the scientific method of indirect verification (e.g. arguments from miracles or from design). As Mitchell comments:

the Logical Positivist movement started as an attempt to make a clear demarcation between science 
and common sense on the one hand, and metaphysics and theology on the other. But work in the philosophy of science convinced people that what the Logical Positivists had said about science was not true, and, by the time the philosophers of science had developed and amplified their accounts of how rationality works in science, people discovered that similar accounts applied equally well to the areas which they had previously sought to exclude, namely theology and metaphysics. 52

Finally, as R. Douglas Geivett explains, philosophers noticed that the verification principle 'was neither empirically verifiable nor tautological.'53 That is, the verification principle was itself a metaphysical claim, a claim that therefore ruled itself to be meaningless: 'it failed its own requirement for factual meaningfulness', notes William P. Alston, 'and thus was self-refuting.' 54

Ayer tried to get around this problem by admitting that the verification principle wasn't a meaningful proposition but saying that it was a rule for using language. But why pay attention to such an arbitrary rule? Ayer himself asked: 'why should anyone follow the prescription if its implications were not to his taste?'55

Keith Ward reports the following conversation between Ayer and a student:

A student once asked [Ayer] if you could make any true general statement about meaningful statements. 'Yes,' he replied. 'You can say that all meaningful statements must be verifiable in principle.' 'I see what you mean,' said the student. 'But how can I verify that?' 'I am glad you asked that,' said the philosopher. 'You cannot verify it. But it is not really a meaningful statement; it is just a rule for using language.'
'Whose rule?' 'Well, it's my rule, really. But it is a very useful one. If you use it, you will find you agree with me completely. I think that would be very useful.' 56

If we adopt the rule, then of course we'll agree with Ayer, and of course he'll find that useful! But he can't provide us with a good reason for adopting his rule (certainly not one that doesn't implicitly contradict the rule he wants us to adopt). Instead, he recommends it on the basis of its usefulness. Usefulness for what? For insulating a worldview that excludes everything metaphysical, especially religion (as the positivist's failed attempts to produce a version of the principle able to draw a line of demarcation between science on the one hand religion on the other hand, shows). Indeed, it would seem that the motivation behind logical positivism was the desire to exclude God by excluding talk about God. Logical positivism was quite simply a form of atheistic censorship. However, philosophers who opposed this baseless peerpressure were well within their rights to point out that the Emperor of positivism had no clothes, but brazenly walked the halls of academia with nothing but a smile of fashionable popularity to disguise his embarrassingly self-contradictory ways.

James Kelly Clark describes the verification principle as a piece of 'unjustifiable philosophical imperialism that, in the end, could not survive critical scrutiny.' 57 William Lane Craig comments: 'Fifty years ago philosophers widely regarded talk about God as literally meaningless . . . but today no informed philosopher could take such a viewpoint.'58 Ronald H. Nash concludes that positivism is dead and quite properly so.' 59 Roger Scruton observes: 'Logical positivism no longer has a 
following, and it is easy to see why. The verification principle cannot be verified: it therefore condemns itself as meaningless.'60

By 1973 Ayer himself admitted: 'the verification principle is defective . . .'61 Talking about positivism during an interview in 1978, Ayer conceded: 'Nearly all of it was false.' 62 He reflected: 'I just stated [the verification rule] dogmatically and an extraordinary number of people seemed to be convinced by my assertion.' 63 In the end, Ayer conceded: 'Logical Positivism died a long time ago. I don't think much of Language, Truth and Logic is true. I think it is full of mistakes.' 64

\section{The Resurrection of God-Talk}

On 8 April 1966, Time Magazine ran a cover story about the then current 'deathof-God' movement in American theology entitled 'Is God Dead?' William Lane Craig explains that:

According to the movement's protagonists, traditional theism was no longer tenable and had to be once and for all abandoned. Ironically, however, at the same time that theologians were writing God's obituary, a new generation of young philosophers was rediscovered His vitality. 65

Only a few years later, Time carried a cover story asking 'Is God coming back to life?' Interest in the philosophy of religion continued to grow to the point where, in 1980, Time ran a story about 'Modernizing the case for God', describing the contemporary movement among philosophers putting new life into the arguments for God's existence:

In a quiet revolution in thought and argument that hardly anybody could have foreseen only two decades ago, God is making a come- back. Most intriguingly, this is happening not amongst theologians or ordinary believers, but in the crisp intellectual circles of academic philosophers, where the consensus had long banished the Almighty from fruitful discourse. 66

The reference to banishing the Almighty from fruitful discourse is a reference to positivism. It's no surprise to find Tyler Burge, Professor of philosophy at UCLA, writing that the central event in philosophy during the last half-century was 'the downfall of positivism and the re-opening of discussion of virtually all the traditional problems of philosophy.' 67 This philosophical renaissance went hand-in-hand with a revival of interest in natural theology amongst analytic philosophers of religion. As James Brent comments: 'Natural theology today is practiced with a degree of diversity and confidence unprecedented since the late Middle Ages.' ${ }^{68}$

\section{Defining 'Natural Theology'}

Thomas Aquinas famously distinguished between 'revealed (dogmatic) theology and rational (philosophical) theology,'69 writing in his Summa Contra Gentiles that:
there exists a twofold truth concer- ning the divine being, one to which the inquiry of the reason can reach, the other which surpasses the whole ability of the human reason, it is fit- ting that both of these truths be proposed to man divinely for be- lief. 70

Aquinas was not making a distinction between truths of reason in the domain of natural theology on the one hand and truths of blind faith on the other. Aquinas' meaning would have been clearer if he'd written that 'there exists a twofold truth concerning the divine being, one to which the inquiry of the reason unaided 
by special revelation can reach, the other which surpasses the whole ability of the human reason unaided by special revelation'. That this is what he meant becomes clear later in Summa Contra Gentiles, where he argues:

Those who place their faith in this truth, however, 'for which the human reason offers no experimental evidence,' do not believe foolishly . . . For these 'secrets of divine Wisdom' (Job 11:6) the divine Wisdom itself ... has deigned to reveal to men. It reveals its own presence, as well as the truth of its teaching and inspiration, by fitting arguments; and in order to confirm those truths that exceed natural knowledge, it gives visible manifestation to works that surpass the ability of all nature ... and what is more wonderful, there is the inspiration given to human minds, so that simple and untutored persons, filled with the gift of the Holy Spirit, come to possess instantaneously the highest wisdom . . .71 [my italics]

In other words, human reason is enabled to reach what it otherwise would not be able to reach - truths of special revelation which surpasses the ability of human reason unaided by special revelation - by the divine design to reveal these truths in such a manner that warrant is thereby provided for rational belief in them.

For Aquinas, this warrant is provided by the Holy Spirit, either quite aside from arguments, or in conjunction with the revelation of 'fitting arguments' and publicly accessible evidence of 'works that surpass the ability of all nature' (that is, miracles). Aquinas argues that the latter, argumentative warrant falls into the category of 'persuasive [i.e. non-deductive] reasoning' rather than that of 'demonstrative reasoning' which 'yields a conclusion that is undeniable for anyone who grasps the truth of the demonstration's premises' 72

Not only does Aquinas make a principled distinction between truths of reason (i.e. truths of natural theology accessible to reason unaided by special revelation) and truths of faith (truths of revealed theology accessible to human reason with the help of special revelation), but he claims to know where the line of this distinction runs:

$$
\begin{aligned}
& \text { Some truths about God exceed all } \\
& \text { the ability of the human reason. } \\
& \text { Such is the truth that God is triune. } \\
& \text { But there are some truths which the } \\
& \text { natural reason also is able to reach. } \\
& \text { Such are that God exists, that He is } \\
& \text { one, and the like. }{ }^{73}
\end{aligned}
$$

While it is wise to recognize that we will never comprehend God, I would argue that it is also wise not to think, with Aquinas, that we can discern in advance of trying to understand some theological topic that this or that topic 'surpasses the whole ability of the human reason' unaided by special revelation. Indeed, not only have Christian philosophers (e.g. Stephen T. Davies) given arguments against a Unitarian definition of $\mathrm{God}^{74}$, some have explicitly argued for God's Tri-unity (e.g. Richard of St Victor, Richard Swinburne and myself ${ }^{75}$ ).

Aquinas' demarcation between natural and revealed theology was highly influential, leading generations of thinkers to assume the existence of a principled division between these disciplines. For example, according to Hugh G. Gauch Jr.:

The task of natural theology is to reach the most significant truths available to unaided reason evaluating public evidence, in contrast to the greater truths available only to faith through a genuine revelation from God. 76 
However, on the one hand, significant truths that natural theologians routinely think 'available to unaided reason evaluating public evidence' can, of course, be taken on faith (treating 'faith' here as a synonym for 'trust'). For example, while advocates of natural theology often endorse cosmological arguments ${ }^{77}$, the author of Hebrews writes: 'By faith we understand that the universe was formed at God's command, so that what is seen was not made out of what was visible.' (Hebrews 11:3.) On the other hand, any 'greater truths available only ... through a genuine revelation from God' can only be the object of faith if human (Godgiven) 'reason' is set to the task of 'evaluating' the relevant revelation (for example, in understanding what a given scriptural passage means).

James F. Sennett and Douglas Groothuis define natural theology as:

The attempt to provide rational justification for theism using only those sources of information accessible to all inquirers, namely, the data of empirical experience and the dictates of human reason. In other words, it is defense of theism without recourse to purported special revelation. 78

Likewise, according to Scot MacDonald:

Natural theology aims at establishing truths or acquiring knowledge about God (or divine matters generally) using . . . standard techniques of reasoning and facts or truths in principle available to all human beings just in virtue of their possessing reason and sense perception. ${ }^{79}$

However, while purported special revelation about Jesus Christ was obviously unavailable to the 'empirical experience and ... reason' of, say, stone-age humans, so too were many cosmological and bio- logical discoveries that ground various contemporary arguments in natural theology (e.g. the 'Big Bang', the precision of cosmic 'fine tuning', the informational nature of life and the existence of molecular machines). Likewise, 'purported special revelation' about Jesus is just as 'accessible to all inquirers' today as are those cosmological and biological discoveries. And again, the purported 'special revelation' available to all inquirers today is only available to them through the same 'empirical experience and ... reason' that they have to use to access the discoveries of modern science.

John Polkinghorne defines natural theology as:

the attempt to learn something of God from the exercise of reason and the inspection of the world - in other words, from reflection on general experience. ${ }^{80}$

However, on the one hand, restricting natural theology to the data of 'general experience' excludes much data (originating from the specialised experience of scientists) with which natural theology is traditionally concerned. On the other hand, if we allow natural theology to work with data grounded in the experience of twenty-first century scientists, why not allow natural theology to work with the apostle Paul's first century experience of encountering the resurrected Jesus? 81

William Lane Craig defines natural theology as:

that branch of theology which seeks to provide rational warrant for the proposition that God exists on the basis of argument and evidence independent of authoritative divine revelation. ${ }^{82}$

However, warrant can be provided 'on the basis of argument and evidence inde- 
pendent of an authoritative divine revelation' qua divine revelation without being independent of that revelation qua a source of potential data, as long as that data is established through the use of standard critical methods. That is, since any argument for theism that assumed the revelatory status of a purported divine revelation would be question begging, stipulating that natural theology should proceed 'without recourse to purported special revelation' qua revelation, 'on the basis of argument and evidence independent of authoritative divine revelation' 83 as such, is redundant.

Of course, we are free to define theological disciplines as proceeding on the assumed basis of 'purported special revelation', or not, as we find it convenient. But such choices imply nothing about the legitimacy of apologetic arguments, including the arguments of natural theology. Thus the website of the famous Gifford Lecturers states that: 'Traditionally natural theology is the term used for the attempt to prove the existence of God and divine purpose through observation of nature and the use of human reason.' 84 While this definition leaves the question of purported special revelation to one side - as may be convenient to do in a university course of a limited duration, or a book of limited size - it doesn't try to erect a principled distinction between natural and revealed theology in the manner of Aquinas.

William P. Alston avoids all these problems when he simply defines natural theology as: 'the enterprise of providing support for religious beliefs by starting from premises that neither are nor presuppose any religious beliefs.' 85 In other words, natural theology seeks to offer a non-question-begging defence of theism.

\section{Ramified Natural Theology}

Recent developments in the philosophy of religion show that 'natural theology' shouldn't be understood in too narrow or insular a manner. ${ }^{86}$ For one thing, as Rodney Holder writes: 'the traditional division between natural theology and revealed theology breaks down as soon as we ask why we should believe in a putative revelation and how we can commend our own perceived revelation to others.' ${ }^{\text {'7 }}$ Then again, what Richard Swinburne has called 'ramified natural theology' 88 (i.e. an expanded, more varied natural theology ${ }^{89}$ ) highlights the fact that so-called 'Christian evidences' (e.g. the argument for Jesus' resurrection ${ }^{90}$, the 'trilemma' argument for the deity of Jesus ${ }^{91}$, arguments about fulfilled Biblical prophe$\mathrm{cy}^{92}$, etc.) don't merely round out the classical case for theism with reasons to believe in a specifically Christian God, but can actually do double-work as argument for God in their own right. ${ }^{93}$

Such arguments don't appeal to special revelation qua special revelation, but they often make non-question-begging appeals to evidence relating to purported acts of special revelation, including evidence contained within the historical documents that Christians call Scripture, as well as evidence outside of Scripture. As Hugh G. Gauch Jr. writes: 'For natural theology's purposes, the Bible is read as historical evidence rather than authoritative scripture ...'94

For example, in the course of arguing for the resurrection of Jesus, an apologist may appeal to the historical datum of the creedal material quoted by the apostle Paul in 1 Corinthians 15 , as well as to archaeological evidence showing that it was possible for a crucified man to receive a decent burial. ${ }^{95}$ As Robert A. Larmer observes: 
Traditionally, it has been assumed that natural theology must eschew consideration of special revelation from God and consider only data that is available to unaided reason. This, however, is to ignore the fact that a purported revelation may include content that is empirically verifiable and thus within the purview of natural theology. Miracles are publicly observable events that cry out for an explanation. One need not come to such events already accepting the interpretation placed on them by religious believers. The Bible can be read as historical evidence rather than authoritative Scripture - but neither is one prohibited from considering whether that interpretation does indeed provide the best understanding of the events. This opens up the possibility that someone who initially does not accept theism might at once accept both the claim of God's existence and the claim of God's selfdisclosure. ${ }^{96}$

This means that natural theology is not restricted to the bare theism (or even deism) of what Pascal famously called 'the God of the Philosophers'.

\section{The Breadth of Contemporary Natural Theology}

Twenty-first century natural theology has rediscovered an emphasis upon the intuitive or 'natural' nature of belief in God'7 in dialogue with what we might call 'epistemologies of trust' (e.g. Richard Swinburne's defence of the principles of credulity and testimony, Alvin Plantinga's 'reformed' account of warrant and properly basic beliefs ${ }^{98}$ and/or Michael Huemer's phenomenal conservatism ${ }^{99}$ ). These epistemologies of trust, together with the sheer breadth of arguments offered within contemporary natural theology, 100 helps us avoid focusing too narrowly upon the 'classical' arguments for God discussed by ancient pagans and/or medieval thinkers (i.e. cosmological, teleological, axiological and ontological arguments),101 although these families of argument have all been ably defended by contemporary scholars. ${ }^{102}$

The breadth of contemporary natural theology is demonstrated by the following half-dozen (or so) exemplars:

- Richard Swinburne's The Existence of God (Clarendon, 1979/2004) defended theistic arguments from the beauty of the natural world and from a philosophical anthropology that includes libertarian free will, conscious thoughts, sensations and desires, the conscious acquisition of warranted true beliefs and various types of religious experience (themes that have been explored in a plethora of more recent publications). 103

- Peter Kreeft and Ronald K. Tacelli sketch nearly 'Twenty Arguments For God's Existence'104 (they actually give nineteen arguments for God's existence plus Pascal's wager argument for belief in God) in their entry level Handbook of Christian Apologetics (IVP, 1994).

- In Defense of Natural Theology: A Post-Humean Assessment (James F. Sennett and Douglas Groothuis ed.'s. IVP Academic, 2005) contains essays defending the project of natural theology from the influential but overrated critiques of David Hume, including defences of nine theistic arguments.

- The Blackwell Companion to Natural Theology (ed. William Lane Craig and J.P. Moreland. Wiley-Blackwell, 2009), contains substantial essays defending nine theistic arguments. 
- The Naturalness of Belief: New Essays on Theism's Rationality (ed. Paul Copan and Charles Taliaferro. Lexington, 2018), offers a wide ranging collection of papers defending theism in light of the phenomena of consciousness, intentionality, beauty, human dignity, free will, rationality and knowledge; as well as looking at common-sensical, existential, psychologi$\mathrm{cal}$, and cultural reasons for theistic belief, in addition to insights from the cognitive science of religion.

- Alvin Plantinga's famous 1986 paper on 'Two Dozen (or so) Arguments for God'105 spawned an academic conference at Baylor University in 2014106 and a subsequent book - The Plantinga Project: Two Dozen (Or So) Arguments For God (ed. Jerry L. Walls and Trent Dougherty. Oxford University Press, 2018) - highlighting 29 theistic arguments, including lesser known arguments such as the argument from desire ${ }^{107}$, play, simplicity, etc.

It bears noting that although philosophical anthropology, philosophical aesthetics and so forth are not the ultimate object of natural theology, since theistic arguments can be mounted that try to make explicit relationships between certain conclusions in these different philosophical disciplines and God's existence, these different subjects are inevitably drawn into the task of elaborating a synoptic Christian worldview through the project of natural theology.

\section{A Brief History of the Natural Sciences in Relation to Natural Theology}

The founding assumption of Western medieval universities was that every academic discipline could be philosophically integrated into a coherent, synoptic worldview provided by Christian theology. Due to the secularizing impetus of the Enlightenment, natural philosophy became detached from theology. In the Victorian era 'natural philosophy' became known as 'science'. In the twentieth century, under the influence of logical positivism, 'science' came to be defined as a search for the best understanding of the natural world consistent with a naturalistic worldview. This supposedly neutral 'methodological naturalism' was turned into a de facto metaphysical naturalism via the condemnation of any dissenting understanding of science as 'pseudo-science'. In recent decades, these philosophical strictures have begun to loosen. ${ }^{108}$ As Garrett J. DeWeese \& J.P. Moreland report: 'The inadequacy of methodological naturalism [is now] widely acknowledged by philosophers of science, even among those who are atheists ...' ${ }^{109}$ For example, atheist philosopher of science Bradley Monton rejects methodological naturalism because it stands in tension with seeing science as a search for the truth:

If science really is permanently
committed to methodological natu-
ralism - the philosophical position
that restricts all explanations in sci-
ence to naturalistic explanations -
it follows that the aim of science is
not generating true theories. In-
stead, the aim of science would be
something like: generating the best
theories that can be formulated
subject to the restriction that the
theories are naturalistic. 110

However one sees the relationship between science and metaphysics, it is obvious that the scientific study of the very large (cosmology) and the very small (e.g. molecular biology) has uncovered a wealth of data that gives support to key premises in various arguments for theism. 
As Rodney Holder comments: 'modern cosmology ... has provided a new impetus to natural theology, reviving traditional arguments but expressing them in new ways.' 111 In the first place, discoveries since the 1960's have overturned the ancient pagan assumption that the cosmos exists without a beginning, thereby rejuvenating the discussion of Kalamtype cosmological arguments.112 Moreover, scientists have uncovered a life-permitting 'fine tuning' at the cosmic ${ }^{113}$ (as well as the planetary114) levels of reality that has rejuvenated the discussion about design in both cosmology and natural theology.

Concurrently, discoveries in biology, including the complex information processing systems and intricate molecular machinery within cells, have rejuvenated discussion about design in both the biological sciences and natural theology. ${ }^{115}$

These scientific discoveries, coinciding with a growing disquiet amongst philosophers of science with attempts to define science as methodologically naturalistic ${ }^{116}$, have led to a discussion of the legitimacy of 'theistic science' (a return to natural philosophy open to indirectly testable theistic hypotheses), 117 as well as the birth of the controversial scientific theory of 'Intelligent Design', a scientific theory that provides material of obvious interest to natural theology. Intelligent Design Theory limits itself to making inferences to design whilst heeding David Hume's point that one cannot thereby infer much about the nature of the designer or designers beyond those qualities necessary to account for the design that has been observed. 118

Scientific contributions to natural theology are not limited to the natural sciences. For example, although it's a relatively young field of study, archaeology has yiel- ded a wealth of data that should be taken into account by the search for the historical Jesus (and thus by ramified natural theology). For example, archaeologists and other scientists have recently uncovered data relevant to discussions about the historical existence of Jesus, the date from which people believed that Jesus was divine, Jesus's crucifixion and burial, etc. ${ }^{119}$ Then again, social sciences have contributed to discussions about the reliability of oral tradition in the ancient near east. 120 Recent decades have also seen various attempts to investigate prayer for healing within the experimental scientific framework. ${ }^{121}$ Hence Christian philosophy and/or apologetics needs to cast its net beyond the waters of the natural sciences if these disciplines are to live up to the synoptic vision of the Christian university.

\section{Some Advice on Apologetics and Natural Theology in an Age of Science}

Natural theology and ramified natural theology are sub-disciplines within both Christian apologetics and the philosophy of religion. To be a 'philosopher' means to be 'a lover of wisdom'. As such, a philosopher is dedicated to the wise pursuit and dissemination of true answers to significant questions through the practice of good intellectual habits, 'speaking the truth in love' (Ephesians 4:15).122 Whether or not one is a professional philosopher, one's philosophical worldview $^{123}$ forms the foundation of one's way of life, that is, one's spirituality. ${ }^{124}$ That is to say, the contents and intellectual habits of our minds, coupled with the choices, commitments and attitudes of our hearts, issue in behaviour that characterizes (and re-enforces) our spirituality 
or 'way of life'. Thus, philosophy is an integral component of any spirituality, including Christian spirituality. 125

Christian spirituality is a Christ-centred way of life, a Christ-centred way of relating to reality via one's head, heart and hands. ${ }^{126}$ By drawing upon a range of disciplines, including natural theology, Christian apologetics aims to enable people to be persuaded that a Christ-centred spirituality is a beautiful, good and reasonable commitment. It is the art of persuasively advocating Christian spirituality, through the responsible use of rhetoric, as being objectively beautiful, good and true/reasonable.127 This being so, Christians should approach natural theology as a more than merely 'academic' pursuit, for as Paul Copan writes:

philosophy should be an act of worship ... when we undertake philosophy in Christ's name, our desk or reading chair becomes an altar, yielding 'a fragrant aroma, an acceptable sacrifice, well-pleasing to God' (Phil 4:18).128

Apologetic appeals to scientific data, theories and/or methodology pack a strong rhetorical punch, partly because such appeals tap into a culturally accepted epistemology and partly because such appeals can undermine the mistaken belief that Christians are anti-science (especially when such appeals embrace the scientific consensus). However, it's worth bearing in mind that when making appealing to science, apologists need to avoid appearing to endorse scientism. ${ }^{129}$ As McGrath comments:

One of the most important functions of natural theology is to protest against the radically reduced visions of nature that arise from the movement sometimes known as 'scientific imperialism' but now generally as simply 'scientism'. 130
Although we live in a culture that encourages a degree of scientific literacy, apologists should consider how receptive nonspecialist audiences are likely to be to theistic arguments that require them to begin learning complex information about cosmology or molecular biology, etc. By comparison, other theistic arguments function at a more intuitive level, at least at a first pass. ${ }^{131}$ For example, the meta-ethical moral argument begins with moral experiences common to, and thus readily understood by, all properly functioning humans from an early age.132 Likewise, the argument from desire is rooted in common human experience. ${ }^{133}$

Whilst Christians should continue to explore the theological fruitfulness of contemporary scientific cosmology and biology, it's worth bearing in mind both that natural theology can draw upon a broad range of scientific subjects beyond the natural sciences (e.g. archaeology and social science can both contribute to ramified natural theology) and upon a broad range of knowledge beyond the limited grasp of science (e.g. meta-ethics, aesthetics, philosophical anthropology). Indeed, making arguments that begin with mental properties such as intentionality, or with moral or aesthetic facts, helps make the point that empirical science isn't the self-justifying golden path to everything that can be known hoped for by the logical positivists. 134

I would encourage Christians to give a higher priority to defending the doctrine of creation (focusing upon the creedal claim that God is the ultimate causer and intender, as well as sustainer, of the cosmos) ${ }^{135}$ than to arguing for any particular model of creation (focusing upon differing interpretations of scriptural creation texts and how they can be best integrated into a synoptic Christian worldview).136 
Concerning the quest for a synoptic model of creation, I agree with Michael J. Murray and Michael Rea that:

for the religious believer, the [resolution of purported] conflicts between science and religion will involve balancing evidence against evidence: the empirical evidence favouring scientific claims against the revelatory evidence favouring theological claims. The Christian [might] conclude that the . . . evidence for an ancient earth seems quite strong, while the evidence for the naturalistic origin of life is, in fact, virtually non-existent. This then needs to be balanced against the evidence of revelation. How clear is it that the Bible teaches that the earth is young, or that God directly intervened in the cosmos to bring about life?137

As Plantinga reminds us:

we can't automatically assume that when there is a conflict between science and our grasp of the teach- ing of Scripture, it is science that is wrong and must give way. But the same holds vice versa; when there is a conflict between our grasp of the teaching of Scripture and current science, we can't assume that it is our interpretation of Scripture that is at fault. It could be that, but it doesn't have to be; it could be because of some mistake or flaw in current science. ${ }^{138}$

Science and theology (including natural theology) are fallible human projects. Wisdom enjoins that we do our best to follow the available evidence where it appears to lead, yet without falling into undue dogmatism. 139

Finally, I'd encourage Christians to engage with the many challenges to and opportunities for apologetics provided by contemporary popular culture, challenges and opportunities that are often focused around science or found within science fiction. 140

\footnotetext{
Notes

1 John Wesley, ‘An Address to the Clergy' http://wesley.nnu.edu/john_wesley/10clergy.htm.

2 As John M. Frame observes: 'For some this belief may be an immediate response to the world around them. For others it may be the result of an argument.' - Steven B. Cowen, ed. Five Views on Apologetics (Grand Rapids, Michigan: Zondervan, 2000), 80. See: Brian K. Morley, Mapping Apologetics: Comparing Contemporary Approaches (Downers Grove, IL: IVP, 2015), 231-232 \& 364.

3 See: Clinton E. Arnold, Acts (Grand Rapids, Michigan: Zondervan, 2002), 134-136. See also: Lars Dahle, 'Acts 17:16-34: An Apologetic Model Then and Now?' Tyndale Bulletin 53.2 (2002) 313-316, https://legacy.tyndalehouse.com/tynbul/Library/TynBull_2002_53_2_09_Dahle_Acts17Apologetic.pdf.

4 Norman L. Geisler, Philosophy of Religion (Grand Rapids, MI: Zondervan, 1974), 208.

5 Alister McGrath, Enriching our Vision of Reality: Theology and the Natural Sciences in Dialogue (West Conshohocken, PA: Templeton Press, 2017), 169.

6 McGrath, Enriching our Vision of Reality, 169.

7 McGrath, Enriching our Vision of Reality, 170.

8 McGrath, Enriching our Vision of Reality, 170.

9 McGrath, Enriching our Vision of Reality, 171.

10 McGrath, Enriching our Vision of Reality, 66.

11 McGrath, Enriching our Vision of Reality, 67.

12 Stephen T. Davis, God, Reason and Theistic Proofs (Edinburugh: Edinburugh University Press, 1997), 13.

13 Alvin Plantinga, 'Two dozen (or so) arguments for God' https://appearedtoblogly.files.wordpress.com/ 2011/05/plantinga-alvin-22two-dozen-or-so-theistic-arguments221.pdf.

14 For discussion of what makes an argument a good argument, see: William Lane Craig and Joseph E. Gorra, Reasonable Response (Chicago, IL: Moody, 2013); Stephen T. Davis, God, Reason and Theistic Proofs (Edinburugh: Edinburugh University Press, 1997); Alvin Plantinga, 'Two dozen (or so) arguments for God' https://appearedtoblogly.files.wordpress.com/2011/05/plantinga-alvin-22two-dozen-or-so-theisticarguments221.pdf.
} 
15 F.C. Copleston in John Hick, ed. The Existence of God (New York: Macmillan, 1964), 178, 180.

16 See: John Hick, ed. The Existence of God (New York: Macmillan, 1964), 120-136.

17 See: John Hick, ed. The Existence of God (New York: Macmillan, 1964), 99-103; Peter S. Williams, A Faithful Guide to Philosophy: A Christian Introduction to the Love of Wisdom (Eugene, Oregon: Wipf and Stock, 2019), chapter six.

18 See: Blaise Pascal, Honor Levi, trans., Pensées and other writings (Oxford: Oxford University Press, 1995), 52.

19 Thomas Aquinas's fifth way from Summa Theologica in Hick, ed. The Existence of God, 85.

20 See: Richard Swinburne, 'The Justification of Theism' www.leaderu.com/truth/3truth09.html; Richard Swinburne, 'Evidence for God' (1986) http://christianevidence.org/docs/booklets/evidence_for_god.pdf; Richard Swinburne, The Existence of God, second edition (Cambridge: Clarendon Press, 2004); The Resurrection of God Incarnate (Cambridge: Clarendon Press, 2003). See also: Rodney Holder, Ramified Natural Theology in Science and Religion (London: Routledge Science and Religion Series, 2020).

21 See: David Sedley, Creationism And Its Critics In Antiquity (California: University of California Press, 2007).

22 See: Hugh Montifiore, The Probability of God (London: SCM, 1985), chapter one.

23 Peter May, 'Karl Barth and Natural Theology?'

www.bethinking.org/is-christianity-true/karl-barth-and-natural-theology. As Wyatt Houtz writes: 'Barth's protest against Natural Revelation was also a protest against the Nazi claim to be a revelation of God.' 'Karl Barth's No! to Natural Theology: Secular Parables of the Kingdom' https://postbarthian.com/2016/07/22/karl-barths-no-natural-theology-secular-parables-kingdom/. See also: James Barr, 'Natural Theology in This Century: Concepts and Approaches', www.giffordlectures.org/books/biblical-faith-and-natural-theology/1-natural-theology-century-concepts-andapproaches.; Rodney Holder, The Heavens Declare: Natural Theology and the Legacy of Karl Barth (West Conshohocken, PA: Templeton Press, 2012).

24 May, 'Karl Barth and Natural Theology?'

25 May, 'Karl Barth and Natural Theology?'

26 See: Alister McGrath, Enriching our Vision of Reality (West Conshohocken, PA: Templeton Press, 2017), 56-58. See also William Lane Craig, 'Classical Apologetics' in Steven B. Cowen, ed. Five Views On Christian Apologetics (Grand Rapids, MI: Zondervan, 2000), 39-43.

27 For example: 'Disillusioned with Dawkins: My Journey from Atheism to Christianity: Peter Byrom' www.solas-cpc.org/disillusioned-with-dawkins-my-journey-from-atheism-to-christianity-peter-byrom/.

28 Kelly James Clark, Philosophers Who Believe: The Spiritual Journeys Of 11 Leading Thinkers (Downers Grove, Illinois: IVP, 1993), Introduction

www.calvin.edu/academic/philosophy/writings/pwbintro.htm.

29 Clark, Philosophers Who Believe, Introduction.

30 Clark, Philosophers Who Believe, Introduction.

31 See: Lewis Carroll, 'Jabberwocky', https://interestingliterature.com/2016/01/22/a-short-analysis-of-jabberwocky-by-lewis-carroll/.

32 Wikipedia, 'A.J. Ayer' http://en.wikipedia.org/wiki/A._J._Ayer.

33 A.J. Ayer, Language, Truth and Logic, 2nd edition (London: Victor Gollancz, 1946), 115.

34 Ayer, Language, Truth and Logic, 175.

35 A.J. Ayer, The Central Questions of Philosophy (London: Penguin, 1973), 118-119. cf. C.S. Lewis, The Abolition of Man (Grand Rapids, MI: Zondervan, 2001).

36 F.C Copleston, Contemporary Philosophy: Studies of Logical Positivism and Existentialism (London: Burns \& Oates, 1957), 9.

37 Hilary Spurling, 'The Wikedest Man in Oxford' www.nytimes.com/books/00/12/24/reviews/001224.24spurlit.html.

38 Spurling, 'The Wickedest Man in Oxford'.

39 E.L. Mascall, He Who Is (New York: Longmans, Green and Co., 1954), Preface, xi.

40 Copleston, Contemporary Philosophy, 9.

41 Bruce R. Reichenbach, The Cosmological Argument: A Reassessment (Springfield, Illinois: Charles C. Thomas, 1972), ix.

42 Victor Reppert, C. S. Lewis's Dangerous Idea (Downers Grove, IL: IVP, 2003), 20.

43 F.C. Copleston, 'Logical Positivism-A Debate' in A Modern Introduction to Philosophy, Paul Edwards and Arthur Pap, ed.'s. (New York: The Free Press, 1965), 756.

44 John Hick, 'Theology and Verification' in Basil Mitchell, ed. The Philosophy of Religion (Oxford: Oxford University Press, 1971), 69. 
45 'According to Newton's law of gravitation, the more distant a star is from the centre of a spiral galaxy, the lower its orbiting velocity. However, observations showed that even stars in the far periphery of a galaxy orbited at nearly the same speed as those closer to the centre. To our eyes, galactic mass appears concentrated towards the centre and diminishes towards the periphery. And yet the stars at the periphery move as if they are embedded in much greater mass ... The unseen matter, by inference, must be a major component of galaxies. This came to be known as 'dark matter.' This non-luminous matter has not been confirmed by observations at any electromagnetic wavelength and constitutes at least 90 percent of the universe.' Singapore Science Centre www.science.edu.sg/ssc/detailed.jsp? artid=4191 andtype $=6 \&$ root $=6 \&$ parent $=6 \&$ cat $=65$.

46 See: Douglas Scott and Martin White, 'Cosmic Microwave Background Radiation' www.astro.ubc.ca/people/scott/cmb_intro.html.

47 Lloyd Eby, 'Viewpoint: What is Science? Part I', World Peace Herald (December 16th, 2005) www.wpherald.com/storyview.php?StoryID=20051216-041328-8321r.

48 Hick, 'Theology and Verification', 71.

49 William Lane Craig, Philosophy of Religion: A Reader and Guide (Edinburgh: Edinburgh University Press, 2002), 1.

50 Alvin Plantinga, God and Other Minds (Ithaca, New York: Cornell University Press, 1967), 271.

51 See: Alvin Plantinga, 'The Ontological Argument'

www.lastseminary.com/ontological-argument/Plantinga \%20-\%20The\%20Ontological\%20Argument.pdf.

See also: YouTube Playlist, 'The Ontological Argument for God'

www.youtube.com/playlist?list=PLQhh3qcwVEWjE7hqAz3D6jp7MWjChVYKn; Peter S. Williams and Peter Millican, 'Debating the Ontological Argument'

https://unbelievable.podbean.com/e/debating-the-ontological-argument-peter-s-williams-peter-millican/; Peter S. Williams, 'A Brief Introduction to and Defence of the Modern Ontological Argument' https://theofilos.no/wp-content/uploads/2019/09/3d_Forum_Williams_A-Brief-Introduction-to-and-Defenceof-the-Modern-Ontological-Argument.pdf; Peter S. Williams, A Faithful Guide to Philosophy: A Christian Introduction to the Love of Wisdom (Eugene, Oregon: Wipf and Stock, 2019).

52 Basil Mitchell, 'Reflections on C.S. Lewis, Apologetics, And the Moral Tradition: Basil Mitchell in Conversation with Andrew Walker' in Andrew Walker and James Patrick, ed.'s. Rumours of Heaven: Essays in Celebration of C.S. Lewis (Guildford: Eagle, 1998), 19.

53 R. Douglas Geivett, 'The evidential Value of Religious Experience' in Paul Copan and Paul K. Moser, ed.'s. The Rationality of Theism (London: Routledge, 2003), 175.

54 William P. Alston, 'Religious Language and Verificationism', Copan and Moser, ed.'s. The Rationality of Theism, 21.

55 Ayer, The Central Questions of Philosophy, 34.

56 Keith Ward, God: A Guide for the Perplexed (Oxford: OneWorld, 2002), 184.

57 Clark, Philosophers Who Believe, 11-12.

58 William Lane Craig, 'Advice to Christian Apologists'

www.baptistpastors.org.au/Mosaic/Spring_Summer_2002/lane_advice_to_apologists.htm.

59 Ronald H. Nash, Faith and Reason (Grand Rapids, Michigan: Zondervan, 1988), 53.

60 Roger Scruton, An Intelligent Person's Guide To Philosophy (London: Duckworth, 1997), 18.

61 Ayer, The Central Questions of Philosophy, 22-34.

62 A.J. Ayer, The Listener, 2 March 1978.

63 A.J. Ayer, quoted by Keith Ward, The Turn of the Tide (London: BBC Publications, 1986), 59.

64 A.J. Ayer in Roy Abraham Vargese ed., Great Thinkers on Great Questions (Oxford: OneWorld, 1998), 49.

65 William Lane Craig, Philosophy of Religion: A Reader and Guide (Edinburgh: Edinburgh University Press, 2001), 1.

66 'Modernizing the Case for God', Time Magazine, 7 April 1980, 65-66.

67 Tyler Burge, 'Philosophy of Language and Mind' Philosophical Review 101 (1992), 49.

68 James Brent, 'Natural Theology' in Internet Encyclopedia of Philosophy, www.iep.utm.edu/theo-nat/\#H4.

69 James Swindal, 'Faith and Reason' in Internet Encyclopedia of Philosophy, www.iep.utm.edu/faith-re/\#SH4e.

70 Thomas Aquinas, Summa Contra Gentiles, https://dhspriory.org/thomas/english/ContraGentiles1.htm\#4.

71 Aquinas, Summa Contra Gentiles, https://dhspriory.org/thomas/english/ContraGentiles1.htm\#6, my italics.

72 Shawn Floyd, 'Aquinas: Philosophical Theology' in Internet Encyclopedia of Philosophy, www.iep.utm.edu/aq-ph-th/\#SH3c.

73 Aquinas, Summa Contra Gentiles, https://dhspriory.org/thomas/english/ContraGentiles1.htm\#3. 
74 See: Stephen T. Davies, 'A Somewhat Playful Proof of the Social Trinity in Five Easy Steps', Philosophia Christi, Series 2, Vol.1, No.2, 103; J.P. Moreland and William Lane Craig, Philosophical Foundations for a Christian Worldview (Downers Grove, IL: IVP, 2003), 594-595.

75 See: Richard of St Victor, On the Trinity (Eugene, Oregon: Cascade, 2011); Richard Swinburne, The Christian God (Oxford: Oxford University Press, 1995); Peter S. Williams, 'Understanding the Trinity' www.bethinking.org/god/understanding-the-trinity.

76 Hugh G. Gauch Jr., 'Recent Transitions in Natural Theology: The Emergence of a Bolder Paradigm ( IBRI Research Reports Book 58).' www.amazon.co.uk/Recent-Transitions-Natural-Theology-Emergence-ebook/dp/B009EIKNMY.

77 See: Dallas Willard, 'Language, Being, God, and the Three Stages of Theistic Evidence' www.dwillard.org/articles/individual/language-being-god-and-the-three-stages-of-theistic-evidence; Peter S. Williams, 'A Universe From Someone - Against Lawrence Krauss' (2012) www.bethinking.org/is-there-a-creator/a-universe-from-someone-against-lawrence-krauss.

78 James F. Sennett and Douglas Groothuis, 'Introduction' in James F. Sennett and Douglas Groothuis, ed.'s. In Defence of Natural Theology: A Post-Humean Assessment (Downers Grove, IL: IVP Academic, 2005), 10.

79 Scott MacDonald, 'Natural Theology' Routledge Encyclopedia of Philosophy www.rep.routledge.com/articles/thematic/natural-theology/v-1.

80 John Polkinghorne, 'Where Is Natural Theology Today?' Science and Christian Belief 18 (2006): 169.

81 See: Peter May, 'The Resurrection of Jesus and the Witness of Paul' www.bethinking.org/did-jesus-rise-from-the-dead/the-resurrection-of-jesus-and-the-witness-of-paul; Peter S. Williams, Getting at Jesus (Eugene, Oregon: Wipf and Stock, 2019).

82 William Lane Craig, ed. Philosophy of Religion: A Reader and Guide, 'Natural Theology: Introduction' (New Jersey: Rutgers University Press, 2002), 69.

83 Craig, ed. Philosophy of Religion, 69. Likewise, Colin Brown defined natural theology as 'the attempt to attain an understanding of God and his relationship with the universe by means of rational reflection, without an appeal to special revelation.' (Sinclair B. Ferguson and David F. Wright, ed.'s. New Dictionary of Theology (Leicester: IVP, 1988), 452.

84 www.giffordlectures.org/overview/natural-theology.

85 William P. Alston, quoted by Rodney Holder, Ramified Natural Theology in Science and Religion (London: Routledge Science and Religion Series) (Kindle Android version, 2020), 19.

86 See: Robert A. Larmer, 'The 'Argument From Miracle': An Example of Ramified Natural Theology' www.epsociety.org/userfiles/art-Larmer\%20(ArgumentFromMiracle-ExampleOfRamified).pdf; Angus Menuge and Charles Taliaferro 'Introduction to a Special Issue of Philosophia Christi on Ramified Natural Theology' www.epsociety.org/library/articles.asp?pid=195; Angus Menuge, 'Ramified Personalized Natural Theology: A Third Way?' www.epsociety.org/userfiles/art-Menuge\%20(Ramified\%20Personalized\%20Natural\%20Theology).pdf.

87 Rodney Holder, Ramified Natural Theology in Science and Religion (London: Routledge Science and Religion Series) (Kindle Android version, 2020),78.

88 Richard Swinburne, 'Natural Theology, Its "Dwindling Probabilities" and "Lack of Rapport"' Faith and Philosophy 21(4): 533-546 (2004).

89 To 'ramify' means 'to spread and develop many parts or branches.' Accordingly, 'Ramified' means 'having many different parts or branches' https://dictionary.cambridge.org/dictionary/english/ramify.

90 See: Craig Blomberg and Carl Stecher with contributions by Richard Carrier and Peter S. Williams, Resurrection: Faith or Fact? A Scholars' Debate Between a Skeptic and a Christian (Durham, North Carolina: Pitchstone, 2019); Peter S. Williams, 'Resurrection: Faith or Fact? Miracle Not Required?' https://theofilos.no/wp-content/uploads/2020/03/Theofilos-vol.-11-nr.-2-2019-Forum-3-Arkiv.pdf; Peter S. Williams, Getting at Jesus: A Comprehensive Critique of Neo-Atheist Nonsense About the Jesus of History (Eugene, Oregon: Wipf \& Stock, 2019).

91 See: Williams, Getting at Jesus: A Comprehensive Critique of Neo-Atheist Nonsense About the Jesus of History (Eugene, Oregon: Wipf \& Stock, 2019).

92 See: YouTube Playlist, 'Biblical Prophecy'

www.youtube.com/playlist?list=PLQhh3qcwVEWgq_Hba52LXvmcUHR4T01oa; Robert C. Newman, ed. The Evidence of Prophecy: Fulfilled Prediction as a Testimony to the Truth of Christianity (Hatfield, Pennsylvania: IBIR, 1998); Peter S. Williams, Understanding Jesus (Milton Keynes: Paternoster, 2011). 93 See: Angus Menuge and Charles Taliaferro 'Introduction to a Special Issue of Philosophia Christi on Ramified Natural Theology' www.epsociety.org/library/articles.asp?pid=195.

94 Gauch Jr., 'Recent Transitions in Natural Theology'.

95 See: Williams, Getting at Jesus (Eugene, Oregon: Wipf \& Stock, 2019).

96 Robert A. Larmer, 'The “Argument From Miracle”: An Example of Ramified Natural Theology' www.epsociety.org/userfiles/art-Larmer\%20(ArgumentFromMiracle-ExampleOfRamified).pdf. 
97 See: C. Stephen Evans, Natural Signs and Knowledge of God: A New Look at Theistic Arguments (Oxford: Oxford University Press, 2012); Paul Copan and Charles Taliaferro, ed.'s. The Naturalness of Belief: New Essays on Theism's Rationality (London: Lexington, 2018).

98 See: Alvin Plantinga, Knowledge and Christian Belief (Grand Rapids, Michigan: Eerdmans, 2015); Alvin Plantinga Warranted Christian Belief (Oxford: Oxford University Press, 2000). See also: Stephen Wykstra, “"Not Done in a Corner” Revisited: Becoming a More Sensible Evidentialist about Jesus' (2017) https://youtu.be/7Tmngq3ZR1w; Mitch Stoke, A Shot of Faith (to the Head): Be a Confident Believer in an Age of Cranky Atheists (Nashville, Tennessee: Thomas Nelson, 2012).

99 See: CCA, 'Phenomenal Conservatism, Evidentialism, and Religious Epistemology (Dr. Chris Tucker)' https://youtu.be/LgBlLnT3h38; Michael Huemer, 'Compassionate Phenomenal Conservatism' www.academia.edu/4446095/Compassionate_Phenomenal_Conservatism; Luca Moretti, 'phenomenal conservatism' https://core.ac.uk/download/pdf/204175534.pdf.

100 See: YouTube Playlist: 'Natural Theology' YouTube playlist:

www.youtube.com/playlist?list=PLQhh3qcwVEWiDA8QN4h8wLrrbm49fLzPN; YouTube Playlist, 'Debating God' YouTube playlist: www.youtube.com/playlist?list=PLQhh3qcwVEWiY3UmTA iRdj2OW4SBG0y_W.

101 See: David Sedley, Creationism And Its Critics In Antiquity (Berkeley: University of California Press, 2007); Frederick Copleston, A History of Philosophy: Volume 2 - Medieval Philosophy (New York: Continuum, 2003).

102 See: William Lane Craig, 'Five Arguments for God'

http://christianevidence.org/docs/booklets/five_arguments_for_god.pdf; William Lane Craig and J.P.

Moreland, The Blackwell Companion to Natural Theology (Wiley-Blackwell, 2009); J.P. Moreland and William Lane Craig, Philosophical Foundations for a Christian Worldview, second edition (Downers Grove, IL: IVP, 2017); J.P. Moreland, Scaling the Secular City: A Defence of Christianity (Grand Rapids, Michigan: Baker, 1987); James F. Sennett and Douglas Groothuis, ed.'s. In Defence of Natural Theology: A PostHumean Assessment (Downers Grove, IL: IVP, 2005); Peter S. Williams, Outgrowing God? A Beginner's Guide to Richard Dawkins and the God Debate (Eugene, Oregon: Cascade, 2020); Peter S. Williams, A Faithful Guide to Philosophy: A Christian Introduction to the Love of Wisdom (Eugene, Oregon: Wipf and Stock, 2019).

103 See: Gregory Bassham ed. C.S. Lewis's Christian Apologetics: Pro and Con (Leiden: Brill/Rodopi, 2015); Thomas Dubay, The Evidential Power Of Beauty: Science And Theology Meet (San Francisco: Ignatius, 1999); Angus Menuge, Agents Under Fire: Materialism And The Rationality Of Science (Lanham, Maryland: Rowman \& Littlefield, 2004); J.P. Moreland, The Recalcitrant Imago Dei: Human Persons and the Failure of Naturalism (London: SCM, 2009), J.P. Moreland, Consciousness and the Existence of God: A Theistic Argument (London: Routledge, 2008); J.P. Moreland, Scaling the Secular City: A Defence of Christianity (Grand Rapids, Michigan: Baker, 1987); Alvin Plantinga, Where The Conflict Really Lies: Science, Religion, \& Naturalism (Oxford: Oxford University Press, 2011); Victor Reppert, C.S. Lewis's Dangerous Idea: In Defense of the Argument from Reason (Downers Grove, IL: IVP Academic, 2003); Peter S. Williams, A Faithful Guide to Philosophy: A Christian Introduction to the Love of Wisdom (Eugene, Oregon: Wipf and Stock, 2019); Peter S. Williams, 'Intelligent Design, Aesthetics and Design Arguments' www.arn.org/docs/williams/pw_idaestheticsanddesignarguments.htm; Peter S. Williams 'In Defence of Arguments From Desire' www.peterswilliams.com/2016/11/02/in-defence-of-arguments-from-desire/. 104 See: Peter Kreeft and Ronald K. Tacelli, 'Twenty Arguments For God's Existence' www.peterkreeft.com/topics-more/20_arguments-gods-existence.htm.

105 Alvin Plantinga, 'Two dozen (or so) arguments for God' https://appearedtoblogly.files.wordpress.com/ 2011/05/plantinga-alvin-22two-dozen-or-so-theistic-arguments221.pdf.

106 See: Baylor Institute for the Study of Religion, Plantinga Conference 2014, www.youtube.com/playlist?list=PL0JmtbsEea3gcN5eNq-0JXq2qTwDg7L_Q.

107 See: YouTube Playlist: 'The Argument from Desire'

www.youtube.com/playlist?list=PLQhh3qcwVEWj3nK3TBydEVAFRtdqfrpW2; Peter S. Williams, 'A Beginner's Guide to the Theistic Argument from Desire' www.solas-cpc.org/a-beginners-guide-to-the-theistic-argument-from-desire/; Gregory Bassham ed. C.S. Lewis's Christian Apologetics: Pro and Con (Leiden: Brill/Rodopi, 2015), 27-74; Peter S. Williams 'In Defence of Arguments From Desire' www.peterswilliams.com/2016/11/02/in-defence-of-arguments-from-desire/; Joe Puckett Jr. The Apologetics of Joy: A Case for the Existence of God from C.S. Lewis's Argument from Desire (Cambridge: Lutterworth, 2013).

108 See: Peter S. Williams, 'Atheists Against Darwinism: Johnson’s Wedge Breaks Through' http://epsociety.org/library/articles.asp?pid=66; Jonathan Bartlett and Eric Holloway, ed.'s. Naturalism And Its Alternatives In Scientific Methodologies (Broken Arrow, Oklahoma: Blyth Institute Press, 2017); Bruce L. Gordon and William A. Dembski, ed.'s. The Nature of Nature: Examining the Role of Naturalism in Science (Wilmington, DE: ISI Books, 2011); J.P. Moreland, ed. The Creation Hypothesis: Scientific Evidence for an Intelligent Designer (Downers Grove, IL: IVP, 1994); Del Ratzsch, Science \& Its Limits: The Natural Sciences in Christian Perspective, second edition (Downers Grove, IL: IVP, 2000). 
109 Garrett J. DeWeese and J.P. Moreland, Philosophy Made Slightly Less Difficult (Downers Grove, IL: IVP, 2005), 146.

110 Bradley Monton, 'Is Intelligent Design Science? Dissecting the Dover Decision'

http://philsci-archive.pitt.edu/archive/00002592/01/Methodological_Naturalism_Dover_3.doc.

111 Holder, Ramified Natural Theology in Science and Religion, 4.

112 See: Paul Copan and William Lane Craig, ed.'s. The Kalam Cosmological Argument, Volume 2: Scientific Evidence for the Beginning of the Universe (New York: Bloomsbury Studies in Philosophy of Religion, 2019); J.P. Moreland and William Lane Craig, Philosophical Foundations for a Christian Worldview, second edition (Downers Grove, IL: IVP, 2017); Peter S. Williams, A Faithful Guide to Philosophy (Eugene, Oregon: Wipf and Stock, 2019).

113 See: Robin Collins' Fine-Tuning Website, http://home.messiah.edu/ rcollins/Fine-tuning/FT.HTM; Paul Davies, The Goldilocks Enigma (London: Penguin, 2007); J.P. Moreland and William Lane Craig, Philosophical Foundations for a Christian Worldview, second edition (Downers Grove, IL: IVP, 2017); Peter S. Williams, Outgrowing God? A Beginner's Guide to Richard Dawkins and the God Debate (Eugene, Oregon: Cascade, 2020).

114 See: Guillermo Gonzalez and Jay W. Richards, The Privileged Planet: How Our Place In The Cosmos Is Designed For Discovery (Washington, DC: Regnery, 2004).

115 See: William A. Dembski and Jonathan Wells, The Design of Life: Discovering Signs of intelligence in Biological Systems (Foundation for Thought and Ethics, 2008); Chad Meister, Introducing Philosophy of Religion (London: Routledge, 2009). See also: Michael J. Behe, Darwin Devolves: The New Science about DNA That Challenges Evolution (HarperOne, 2019), The Edge of Evolution: The Search for the Limits of Darwinism (New York: Free Press, 2007) \& Darwin's Black Box: The Biochemical Challenge to Evolution, $10^{\text {th }}$ anniversary edition (New York: Free Press, 2006); Matti Leisola and Jonathan Witt, Heretic: One Scientist's Journey from Darwin to Design (Seattle: Discovery Institute, 2018); Robert J. Marks II, William A. Dembski and Winston Ewert, Introduction to Evolutionary Informatics (Singapore: World Scientific, 2017); Stephen C. Meyer, Darwin's Doubt: The Explosive Origin Of Animal Life And The Case For Intelligent Design (New York: HarperOne, 2013) \& Signature In The Cell: DNA And The Evidence For Intelligent Design (New York: HarperOne, 2009); Charles B. Thaxton et al, The Mystery of Life's Origin: The Continuing Controversy (Seattle: Discovery Institute, 2020); Peter S. Williams, 'Intelligent Designs on Science' www.peterswilliams.com/2016/02/09/intelligent-designs-on-science/, 'Atheists Against Darwinism: Johnson's Wedge Breaks Through' http://epsociety.org/library/articles.asp?pid=66, 'The Design Inference from Specified Complexity Defended by Scholars Outside the Intelligent Design Movement: A Critical Review' Philosophia Christi (Vol. 9, Issue 2, 2007)

www.discovery.org/scripts/viewDB/filesDB-download.php?command=download\&id=1491; Outgrowing God? A Beginners' Guide to Richard Dawkins and the God Debate (Eugene, Oregon: Cascade, 2020); A Faithful Guide to Philosophy: A Christian Introduction to the Love of Wisdom (Eugene, Oregon: Wipf and Stock, 2019) \& I Wish I Could Believe In Meaning: A Response To Nibilism (Southampton: Damaris, 2004).

116 See: Del Ratzsch, Science \& Its Limits: The Natural Sciences in Christian Perspective, second edition (Downers Grove, IL: IVP, 2000).

117 See: J.P. Moreland ed., The Creation Hypothesis: Scientific Evidence for an Intelligent Designer (Downers Grove, IL: IVP, 1994); Fuzale Rana and Hugh Ross, Origins of Life: Biblical and Evolutionary Models Face Off (Covina, CA: RTB Press, 2014).

118 See: YouTube Playlist, 'Debating Intelligent Design Theory'

www.youtube.com/playlist?list=PLQhh3qcwVEWhO4mPNzA-K41C7VfvSvkQW; William A. Dembski \& Jonathan Wells, The Design of Life: Discovering Signs of intelligence in Biological Systems (Richardson, Texas: Foundation for Thought and Ethics, 2008); Bruce L. Gordon and William A. Dembski, ed.'s. The Nature of Nature: Examining the Role of Naturalism in Science (Wilmington, DE: ISI Books, 2011); Bradley Monton, Seeking God in Science: An Atheist Defends Intelligent Design Theory (Peterborough, Canada: Broadview Press, 2009); Peter S. Williams, 'The Design Inference from Specified Complexity Defended by Scholars Outside the Intelligent Design Movement: A Critical Review' Philosophia Christi (Vol. 9, Issue 2, 2007) www.discovery.org/scripts/viewDB/filesDB-download.php? command=download\&id=1491; 'Atheists Against Darwinism: Johnson's Wedge Breaks Through' http://epsociety.org/library/articles.asp?pid=66; 'Intelligent Designs on Science' (2006) www.peterswilliams.com/2016/02/09/intelligent-designs-on-science/

and 'Design and the Humean Touchstone' www.arn.org/docs/williams/pw_humeantouchstone.htm.

119 See: Craig A. Evans, Jesus and the Remains of His Day: Studies in Jesus and the Evidence of Material Culture (Peabody, Massachusetts: Henderickson, 2015); Peter S. Williams, 'Archaeological Evidence and Jesus' https://youtu.be/ZaGlKZqED1k; Peter S. Williams, 'Archaeological Evidence and Jesus' http://podcast.peterswilliams.com/e/elf-2020-archaeological-evidence-and-jesus/, Peter S. Williams, 'Defending Early High Christology with Archaeology and New Testament Letters' https://youtu.be/vUha7-4Puy8; Peter S. Williams, 'Digging for Evidence: Archaeology and the Historical Reliability of the New Testament' Christian Evidence Society (2016) http://christianevidence.org/docs/booklets/digging_for_evidence.pdf \& Peter S. 
Williams, Getting at Jesus: A Comprehensive Critique of Neo-Atheist Nonsense About the Jesus of History (Eugene, Oregon: Wipf and Stock, 2019).

120 See: Paul Rhodes Eddy and Gregory A. Boyd, The Jesus Legend: A Case for the Historical Reliability of the Synoptic Jesus Tradition (Grand Rapids, Michigan: Baker Academic, 2007).

121 See: Candy Gunther Brown, Testing Prayer (Cambridge, Massachusetts: Harvard University Press, 2012).

122 See: Peter S. Williams, A Faithful Guide to Philosophy (Eugene, Oregon: Wipf and Stock, 2019).

123 See: YouTube Playlist, 'Understanding Worldviews'

www.youtube.com/playlist?list=PLQhh3qcwVEWhCn7rqlW7UsvFNRjQ9wxoH;

James W. Sire, The Universe Next Door: A Basic Worldview Catalogue, fifth edition (IVP, 2009).

124 See: Peter S. Williams, 'Apologetics in 3D - "Input” at Trondheim Frikirke' (2018)

http://podcast.peterswilliams.com/e/apologetics-in-3d-input-at-trondheim-frikirke/ \& 'Apologetics in 3D:

Persuading Across Spiritualities With the Apostle Paul', Theofilos (2012:1)

www.bethinking.org/apologetics/apologetics-in-3d.

125 See: YouTube Playlist, 'Discipleship \& Spiritual Formation'

www.youtube.com/playlist?list=PLQhh3qcwVEWhGSK1x6H3qeqzefB8hmvvM; André Comte-Sponville, The Book Of Atheist Spirituality: An Elegant Argument For Spirituality Without God (London: Bantam, 2007); Philip Sheldrake, Spirituality: A Very Short Introduction (Oxford: Oxford University Press, 2012); Peter S. Williams, 'Apologetics in 3D' https://youtu.be/hiUHeaEaPLA; Peter S. Williams, 'Apologetics in 3D - "Input" at Trondheim Frikirke' (2018)

http://podcast.peterswilliams.com/e/apologetics-in-3d-input-at-trondheim-frikirke/; 'Apologetics in 3D:

Persuading Across Spiritualities With the Apostle Paul', Theofilos (2012:1)

www.bethinking.org/apologetics/apologetics-in-3d \& Understanding Jesus: Five Ways to Spiritual

Enlightenment (Milton Keynes: Paternoster, 2011).

126 See: Peter S. Williams, 'Discipleship in 3D: Change for head, heart and hands'

https://youtu.be/QTyEo0JgIBI; Peter S. Williams, 'Apologetics in 3D: Persuading across Spiritualities with the Apostle Paul', Theofilos 2012:1, 3-24, www.bethinking.org/apologetics/apologetics-in-3d.

127 See: Peter S. Williams, 'Apologetics in 3D' https://youtu.be/hiUHeaEaPLA; Peter S. Williams, 'Apologetics in 3D - "Input" at Trondheim Frikirke' (2018)

http://podcast.peterswilliams.com/e/apologetics-in-3d-input-at-trondheim-frikirke/; Peter S. Williams,

'The Apologetics of Cultural Re-Enchantment in 3D: Makoto Fujimura's Culture Care \& Paul M. Gould's

Cultural Apologetics' Theofilos 2019/1 (June / July), 79-88, https://theofilos.no/wp-content/uploads/

2020/03/3e_Forum_Williams_The-Apologetics-of-Cultural-Re-Enchantment-in-3D.pdf; Peter S. Williams,

'Apologetics in 3D: Persuading across Spiritualities with the Apostle Paul' Theofilos (2012:1), 3-24,

www.bethinking.org/what-is-apologetics/advanced/apologetics-in-3d.htm.

128 Paul Copan, A Little Book for New Philosophers (Downers Grove, Illinois: IVP Academic, 2016), 119-120.

129 See: Peter S. Williams, YouTube Playlist: 'Scientism'

www.youtube.com/playlist?list=PLQhh3qcwVEWiIgrCwkM8Y-RoqU1TmYK8R.

130 McGrath, Enriching our Vision of Reality, 174.

131 See: Peter S. Williams, 'Arguing for God' (August 2020)

http://podcast.peterswilliams.com/e/arguing-for-god/.

132 See: Peter S. Williams, 'Can Moral Objectivism Do Without God?’ Theofilos (2011)

www.bethinking.org/morality/can-moral-objectivism-do-without-god; Peter S. Williams, Outgrowing God?

A Beginner's Guide to Richard Dawkins and the God Debate (Eugene, Oregon: Cascade, 2020), chapter four; A Faithful Guide to Philosophy (Eugene, Oregon: Wipf and Stock, 2019), chapter 8; Robert K. Garcia and Nathan L. King, Is Goodness without God Good Enough? A Debate On Faith, Secularism, And Ethics (Lanham, Maryland: Rowman \& Littlefield, 2009).

133 See: YouTube Playlist: 'The Argument from Desire'

www.youtube.com/playlist?list=PLQhh3qcwVEWj3nK3TBydEVAFRtdqfrpW2; Peter S. Williams, 'A

Beginner's Guide to the Theistic Argument from Desire'

www.solas-cpc.org/a-beginners-guide-to-the-theistic-argument-from-desire/; 'C.S. Lewis as a Central Figure in Formulating the Theistic Argument from Desire', Linguaculture (Volume 10, 2019:2),

http://journal.linguaculture.ro/images/2019-2/Linguaculture\%202_2019_11_Peter\%20S\%20Williams.pdf;

Gregory Bassham ed. C.S. Lewis's Christian Apologetics: Pro and Con (Leiden: Brill/Rodopi, 2015), 27-74; Peter S. Williams 'In Defence of Arguments From Desire'

www.peterswilliams.com/2016/11/02/in-defence-of-arguments-from-desire/; Joe Puckett Jr. The Apologetics of Joy: A Case for the Existence of God from C.S. Lewis's Argument from Desire (Cambridge: Lutterworth, 2013).

134 See: Peter S. Williams, A Faithful Guide to Philosophy (Eugene, Oregon: Wipf and Stock, 2019), chapters $8,14 \& 15$. 
135 As C. John Collins notes: 'Traditional Christian metaphysics put all these things together by describing God's initial creation - which produced all things - followed by his providential maintaining and ruling what he had made.' - Reading Genesis Well (Grand Rapids, Michigan: Zondervan, 2018), $267 \mathrm{ff}$.

See: Alister McGrath, I Believe: Exploring the Apostle’s Creed (Leicester: IVP, 1997), 29-36.

136 See: Paul Marston, 'Understanding the Biblical Creation Passages'

www.asa3.org/ASA/topics/Bible-Science/understanding_the_biblical_creation_passages.pdf; Matthew Barrett, Ardel B. Caneday and Stanley N. Gundry, ed.'s. Four Views On The Historical Adam (Grand Rapids, MI: Zondervan, 2013); J. Daryl Charles, ed. Reading Genesis 1-2: An Evangelical Conversation (Peabody, Massachusetts: Hendrickson, 2013); Charles Halton and Stanley N. Gundry, ed.'s. Genesis: History, Fiction, or Neither? Three Views On The Bible's Earliest Chapters (Grand Rapids, MI: Zondervan, 2015); J.B. Stump and Stanley N. Gundry, ed.'s. Creation, Evolution, And Intelligent Design (Grand Rapids, MI: Zondervan, 2017); John H. Walton, The Lost World Of Genesis One: Ancient Cosmology and the Origins Debate (Downers Grove, IL: IVP Academic, 2009); John H. Walton, The Lost World Of Adam And Eve: Genesis 2-3 and the Human Origins Debate (Downers Grove, IL: IVP Academic, 2015).

137 Michael J. Murray and Michael Rea, An Introduction to the Philosophy of Religion (Cambridge: Cambridge University Press, 2008), 211. See: John C. Lennox, Seven Days That Divide The World: The Beginning According To Genesis And Science (Grand Rapids, MI: Zondervan, 2011); Stephen C. Meyer, Signature in the Cell: DNA And The Evidence For Intelligent Design (New York: HarperOne, 2009); Charles B. Thaxton et al, The Mystery of Life's Origin: The Continuing Controversy (Seattle: Discovery Institute, 2020).

138 Alvin Plantinga, 'When Faith and Reason Clash: Evolution and the Bible' www3.nd.edu/ afreddos/courses/43150/plantinga.pdf.

139 See: Peter S. Williams, 'Is Christianity Unscientific?' https://youtu.be/mWiU2p_PIE8; Peter S. Williams, 'Is Christianity Unscientific?' Theofilos (2013), www.peterswilliams.com/wp-content/uploads/2013/07/Is-Christianity-Unscientific-Theofilos-Paper.pdf.

140 See: Peter S. Williams, 'A Universe From Someone - Against Lawrence Krauss' (2012)

www.bethinking.org/is-there-a-creator/a-universe-from-someone-against-lawrence-krauss; 'Carl Sagan: The Skeptic's Sceptic' (2008) www.bethinking.org/atheism/carl-sagan-the-skeptics-sceptic; 'In Search Of Innocence: Ghost in a Shell 2' www.peterswilliams.com/2016/02/09/in-search-of-innocence/; Peter S. Williams, Outgrowing God? A Beginner's Guide to Richard Dawkins and the God Debate (Eugene, Oregon Cascade, 2020); Steve Couch, Tony Watkins an Peter S. Williams, Back In Time: A Thinking Fan's Guide to Doctor Who (Southampton: Damaris, 2005); Steve Couch, ed. Matrix Revelations: A Thinking Fan's Guide to the Matrix Trilogy (Southampton: Damaris, 2003). 


\title{
Theofilos
}

A Nordic open access journal in Theology, Philosophy and Culture

Published by NLA University College - in partnership with Johannelund School of Theology

Available at www.theofilos.no

\section{Science and Faith: Friendly Allies, Not Hostile Enemies ${ }^{1}$}

\author{
John Lennox \\ Professor of Mathematics (Emeritus), Associate Fellow of the Saïd Business School, and Emeritus \\ Fellow and Pastoral Adviser of Green Templeton College, \\ The University of Oxford \\ www.jobnlennox.org
}

Contemporary science is a wonderfully collaborative activity. It knows no barriers of geography, race, or creed. At its best, it enables us to wrestle with the problems that beset humanity, and we rightly celebrate when an advance is made that brings relief to millions.

I have spent my life as a pure mathematician, and I often reflect on what physics Nobel Prize-winner Eugene Wigner called "the unreasonable effectiveness of mathematics." How is it that equations created in the head of a mathematician can relate to the universe outside that head? This question prompted Albert Einstein to say, "The only incomprehensible thing about the universe is that it is comprehensible." The very fact that we believe that science can be done is a thing to be wondered at.

Why should we believe that the universe is intelligible? After all, if, as certain secular thinkers tell us, the human mind is nothing but the brain and the brain is nothing but a product of mindless unguided forces, it is hard to see that any kind of truth, let alone scientific truth, could be one of its products. As chemist J.B.S. Haldane pointed out long ago: if the thoughts in my mind are just the motions of atoms in my brain, why should I believe anything it tells me - including the fact that it is made of atoms? Yet many scientists have adopted that naturalistic view, seemingly unaware that it undermines the very rationality upon which their scientific research depends!

It was not - and is not - always so. Science as we know it exploded on to the world stage in Europe in the sixteenth and seventeenth centuries. Why then and why there? Alfred North Whitehead's view, as summarized by C.S. Lewis, was that "men became scientific because they expected Law in Nature, and they expected Law in Nature because they believed in a Legislator."2 It is no accident that Galileo, Kepler, Newton, and ClerkMaxwell were believers in God.

Melvin Calvin, American Nobel Prize laureate in biochemistry, finds the origin of the foundational conviction of science - that nature is ordered - in the basic notion "that the universe is governed by a single God, and is not the product of the whims of many gods, each governing his own province according to his own laws. This monotheistic view seems to be the historical foundation for modern science."3

Belief in God, far from hindering science, was the motor that drove it. Isaac Newton, when he discovered the law of gravitation, did not make the common mistake of saying "now [that] I have a law of gravity, I don't need God.” Instead, he wrote Principia Mathematica, the most famous book in the history of science, expressing the hope that it would persuade 
the thinking reader to believe in a creator.

Newton could see what, sadly, many people nowadays seem unable to see: that God and science are not alternative explanations. God is the agent who designed and upholds the universe; science tells us about how the universe works and about the laws that govern its behavior. God no more conflicts with science as an explanation for the universe than Henry Ford conflicts with the laws of the internal combustion engine as an explanation for the motorcar. The existence of mechanisms and laws is not an argument for the absence of an agent who set those laws and mechanisms in place. On the contrary, their very sophistication, down to the fine tuning of the universe, is evidence for the Creator's genius. For Johannes Kepler, German seventeenth-century mathematician, astronomer and astrologer: "The chief aim of all investigations of the external world should be to discover the rational order which has been imposed on it by God and which he revealed to us in the language of mathematics." 4

As a scientist, then, I am not ashamed or embarrassed to be a Christian. After all, Christianity played a large part in giving me my subject.

The mention of Kepler brings me to another issue. Science is, as I said earlier, by and large a collaborative activity. Yet real breakthrough is often made by a lone individual who has the courage to question established wisdom and strike out on his or her own. Johannes Kepler was one such. He went to Prague as assistant to the astronomer Tycho Brahe, who tasked him with making mathematical sense of observations of planetary motion in terms of complex systems of circles. The view that perfect motion was circular came from Aristotle and had dominated thought for centuries. But Kepler just couldn't make circles fit the observations. He took the revolutionary step of abandoning Aristotle, approaching the observations of the planets from scratch, and seeing what the orbits actually looked like. Kepler's discovery, that the planetary orbits were not circular but elliptical, led to a fundamental paradigm shift for science.

Kepler had the instinct to pay careful attention to things that didn't fit into established theory. Einstein was another such groundbreaker. Things that don't fit in can lead to crucial advances in scientific understanding. Furthermore, there are matters that do not fit into science. For, and it needs to be said in the face of widespread popular opinion to the contrary, science is not the only way to truth. Indeed, the very success of science is due to the narrowness of the range of its questions and methodology.

Nor is science coextensive with rationality. If it were, half our university faculties would have to shut. There are bigger matters in life - questions of history and art, culture and music, meaning and truth, beauty and love, morality and spirituality, and a host of other important things that go beyond the reach of the natural sciences, and, indeed, of naturalism itself. Just as Kepler was initially held back by an assumed Aristotelianism, could it not be that an a priori naturalism is holding back progress by stopping evidence from speaking for itself?

It is to such things that my mind turns when I think of Jesus, the human, above all others, who did not fit into the preconceptions of this world. Just as Johannes Kepler revolutionized science by paying close attention, observing why the planets did not fit in to the mathematical wisdom of the time, I claim that my life and that of many others has been revolutionized by paying close attention to Jesus and 
why He did not, and still does not, fit in to the thinking of this world. Indeed, the fact that Jesus did not fit in is one of the reasons I am convinced of His claim to be the Son of God.

For instance, Jesus does not fit into the category of literary fiction. If $\mathrm{He}$ did, then what we have in the Gospels is inexplicable. It would have required exceptional genius to have invented the character of Jesus and put into His mouth parables that are in themselves literary masterpieces. It is just not credible that all four gospel writers with little formal education between them just happened simultaneously to be literary geniuses of world rank.

Furthermore, there are relatively few characters in literature who strike us as real people, whom we can know and recognize. One of them is my intellectual hero, Socrates. He has struck generation after generation of readers as a real person. Why? Because Plato did not invent him. So it is with Jesus Christ. Indeed, the more we know about the leading cultures of the time, the more we see that, if the character of Jesus had not been a historical reality, no one could have invented it. Why? Because He did not fit in to any of those cultures. The Jesus of the Gospels didn't fit anyone's concept of a hero. Greek, Roman, and Jew - all found Him the very opposite of their ideal.

The Jewish ideal was that of a strong military general, fired with messianic ideals and prepared to fight the Roman occupation. So when Jesus eventually offered no resistance to arrest, it was not surprising that His followers temporarily left Him. He was far from the Jewish ideal leader.

As for the Greeks, some favored the Epicurean avoidance of extremes of pain and pleasure that could disturb tranquility. Others preferred the rationality of
Stoicism, which suppressed emotion and met suffering and death with equanimity, as Socrates had done.

Jesus was utterly different. In the Garden of Gethsemane, facing such intense agony that $\mathrm{He}$ sweat drops of blood, $\mathrm{He}$ asked God to let Him skirt the torturous cross. No Greek would have invented such a figure as a hero.

And the Roman governor Pilate found Christ unworldly and impractical when Jesus told him: "My kingdom is not of this world ... For this purpose I was born and for this purpose I came into the world - to bear witness to the truth" (John 18:36-37).

So, Jesus ran counter to everyone's concept of an ideal hero. Indeed, Matthew Parris, an atheist, suggested in the Spectator recently that if Jesus hadn't existed not even the church could have invented Him! Jesus just did not fit in.

Nor did His message. St. Paul tells us that the preaching of the cross of Christ was regarded by the Jews as scandalous, and by the Greeks as foolish. The early Christians certainly could not have invented such a story. Where, then, did it come from? From Jesus Himself, who said, "The Son of Man came not to be served but to serve, and to give his life as a ransom for many" (Matt. 20:28). Jesus did not fit into the world. So they crucified Him and tried to fit Him in a tomb. But that did not work either. He arose from the dead on the third day.

But doesn't this go against the grain of the science I was praising earlier? Aren't such miracles impossible because they violate the laws of nature? I disagree. To use an illustration based on one offered by C.S. Lewis, on each of two nights, if I put ten pounds (British currency) into my drawer, the laws of arithmetic tell me I have twenty pounds. If, however, on 
waking up I have only five pounds in the drawer I don't conclude that the laws of arithmetic have been broken but possibly the laws of England. 5 The laws of nature describe to us the regularities on which the universe normally runs. God, who created the universe with those laws, is no more their prisoner than the thief is prisoner of the laws of arithmetic. Like my room, the universe is not a closed system, as the secularist maintains. God can, if He wills, do something special, like raise Jesus from the dead.

Note that my knowledge of the laws of arithmetic tells me that a thief has stolen the money. Similarly, if we did not know the law of nature that dead people normally remain in their tombs, we should never recognize a resurrection. We could certainly say that it is a law of nature that no one rises from the dead by natural processes. But Christians do not claim that
Jesus rose by natural processes, but by supernatural power. The laws of nature cannot rule out that possibility.

Philosopher David Hume said that you must reject a miracle as false, unless believing in its falsity would have such inexplicable implications that you would need an even bigger miracle to explain them. That is one good reason to believe in the resurrection of Jesus. The evidence of the empty tomb, the character of the witnesses, the explosion of Christianity out of Judaism, and the testimony of millions today are inexplicable without the resurrection. As Holmes said to Watson: "How often have I said to you that when you have eliminated the impossible, whatever remains, however improbable, must be the truth?" As Russian Christians say at Easter: "Khristos Voskryes. Voiistinu Voskryes! Christ is risen. He is risen indeed!"

\footnotetext{
Notes

1 Previously published in the Winter 2015 issue of the C.S. Lewis Institute publication Knowing \& Doing (www.cslewisinstitute.org/Science_and_Faith_Friendly_Allies_Not_Hostile Enemies_FullArticle). Published in Theofilos with permission from Dr. John Lennox (www.johnlennox.org).

2 C.S. Lewis, Miracles: A Preliminary Study, London: Collins), 1947), 110.

${ }^{3}$ Melvin Calvin, Chemical Evolution (Oxford: Clarendon Press, 1969), 258.

4 Johannes Kepler (1571-1630), Astronomis Nova de Moti- 4 Miracles, 62.

${ }^{5}$ Lewis, op cit, 62.
} 


\title{
Theofilos
}

A Nordic open access journal in Theology, Philosophy and Culture

Published by NLA University College - in partnership with Johannelund School of Theology

Available at www.theofilos.no

\section{Freedoms and Limitations: C. S. Lewis and Francis Schaeffer as a tag team ${ }^{1}$}

\author{
C. John Collins \\ Professor of Old Testament \\ Covenant Theological Seminary, St. Louis, Missouri \\ Jack.Collins@covenantseminary.edu
}

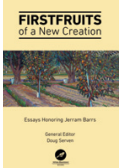

We are grateful for the permission to re-publish this tribute by Genesis specialist C. John ("Jack") Collins to his colleague and friend Jerram Barrs. A version of this article was first published in Firstfruits of a New Creation: Essays Honoring Jerram Barrs (2019).

Barrs was a Worker at L'Abri Fellowship in UK for many years before joining the Faculty at Covenant Theological Seminary in 1989. He was instrumental in founding The Francis Schaeffer Institute as a "means of extending and embodying the legacy of Dr. Francis A. Schaeffer within the context of seminary education". ${ }^{2}$

Some of the ideas from C. S. Lewis in this article are further developed by Jack Collins in Reading Genesis Well: Navigating History, Poetry, Science, \& Truth in Genesis 1-11 (Zondervan, 2018).

The Editors

I count it a great delight to contribute this essay in honor (or should I say, in honour?) of Professor Jerram Barrs, especially since he (together with his associate Ranald Macaulay), Francis Schaeffer, and C. S. Lewis have done so much to shape my own thinking and living as a Christian. To have Professor Barrs as a colleague, and a friend, is a privilege beyond my wildest imagining. And if I focus on Genesis 1-11 in this essay, consider that a tribute to my sharing the 2010 Francis A. Schaeffer lectureship with Professor Barrs on that topic. ${ }^{3}$

\section{Francis Schaeffer introduces "freedoms and limitations"}

Francis Schaeffer (1912-84) had a major influence on Jerram Barrs. Schaeffer served as a Bible Presbyterian pastor in St Louis, and then as a missionary in Europe; he founded and operated L'Abri, with its orientation toward young people. As a pastor and apologist within the great Christian tradition, Schaeffer was convinced that there was "no final conflict" between the sciences and the Bible, when both are properly understood.

But many do interpret the sciences and the Bible as being in conflict; and these alleged conflicts can be the most acute when it comes to the story of origins: the origin of the universe, of life, of the varieties of life forms, and especially of humankind. Christians have tried various ways to address these conflicts; Schaeffer, being both an evangelist eager to remove barriers to coming to Christian faith, and 
a theologian knowing that we must preserve the true Christian faith without diluting it, aimed to give some guidance on just how to address those potential barriers. Schaeffer was also a churchman, considering unnecessary conflict within the church to be destructive of Christian wellbeing and witness.

For these reasons Schaeffer articulated an approach to origins that he called "freedoms and limitations": there is a range of reasonable scenarios by which we may address the apparent conflicts between the Bible and the sciences, and yet there are limits to this range, limits set both by basic Biblical concepts and by good human judgment. 4

Schaeffer was willing to consider, among other freedoms, the possibility that Genesis 1 describes God creating a "grown up universe" (nowadays called the "appearance of age hypothesis"); or that God was reforming a creation that had been partially deformed by Satan's fall; or that the "days" refer to long ages. He concluded, sensibly and generously:

I urge you again to remember that I am not saying that any of these positions are my own or that they will prove to be the case. I am simply stating theoretical possibilities as we consider the correlations between what the Bible sets forth about cosmogony and what we can study from general revelation.

At the same time he wanted to insist, first, on God's special creative activity at certain places; in particular, at the original creation, and then at the creation of conscious life, and again at the creation of man, the result was discontinuous in some way from what had preceded. He also thought it essential to say that Adam was the first man and that Eve was made from him. This left him with a careful view of what is called "theistic evolution": he saw no support for the molecule-to-man sort of naturalistic evolution, and he imagined that anyone who held to his limitations would not be an evolutionist in the fullest sense of the word.

When it comes to assessing Schaeffer's version of specific freedoms and limitations, the first thing to do is to recognize that he has covered the main options that evangelicals in his day had explored. And surely his instincts are right: these explorations come from obviously good people, who are competent scholars; why should we get worked up over their differences? At the same time, a great deal of water has gushed on by under the exegetical bridge since his booklet first saw publication in 1975, and thus I would take his list of freedoms as enumerative and suggestive, rather than exhaustive. The limitations strike me as eminently reasonable, and indeed generous - and, as we will see, they fit well with the arguments of C. S. Lewis.

Further, Schaeffer's approach allows what we might call a "glass half full" style of ministry, whose main goal is to help people adequately face the facts about their humanness - we are distinct from the other animals, and we all need God - without quibbling over every detail. This approach allows us to affirm people, and leave them to develop their own perspectives further - traits that I have seen vividly embodied in Jerram Barrs!

So, all these factors certainly make me admire Schaeffer. In addition, I think another factor, unstated, comes into play as well: namely, a sane Christian has a hierarchy of commitments, and thus, for example, should insist more strongly on the tenets of "mere" or "basic" Christianity - say, the Trinity, or the resurrection of Jesus - than on some other matters 
that are important, but not quite so vital - say, the number of sacraments and their exact effects. Since I am, like Schaeffer and Barrs, a Presbyterian, I appreciate as well the ideal of "generic Calvinism," which allows a range of possible views on a number of matters, within the circle of the Reformed ministry. ${ }^{5}$

My admiration for Schaeffer's approach grows even greater when I add into the mix some insights from C. S. Lewis, the literary scholar. In my judgment, Lewis' insights show that the very nature of the material we have in Genesis leads to some sort of freedoms and limitations rubric, since the material both resists a purely literalistic reading, and invites a recognition of its historical impulse.

In this essay I want to develop these insights from Lewis, and in places to refine them (since they touch on my own area of specialization, namely Genesis). I will also draw on Lewis to defend this approach against some of its critiques, which are still current. And if at times I think I can improve on some particulars in their outlooks, I still think that a "broadly Lewisian" and "broadly Schaefferian" tack when it comes to Genesis will provide us with the intellectually and morally robust tools we need for bringing the message of Genesis to each culture. ${ }^{6}$

\section{What kind of introduction does}

\section{S. Lewis need?}

C. S. Lewis (1898-1963), famous both as a defender of Christian faith and as the writer of imaginative fiction, actually had a day job: he was a professional scholar of medieval and Renaissance European literature. From 1925 until 1954, he was Fellow and Tutor in English Literature at Magdalen College, Oxford; and from 1954 until he retired in 1963 (shortly before he died that same year), he was Professor of
Medieval and Renaissance Literature at Cambridge University. In the course of his academic work he produced books and papers on topics in ideological history, English philology, and literary interpretation, many of which still show considerable value.

Nowadays the general public knows Lewis primarily for the theological, apologetic, and imaginative works; nevertheless his total work hangs together, and the same personal traits come through in all of his writings.

Lewis the apologist wrote when the standard narrative in the Western world was that the advances of the sciences were relegating the archaic beliefs of traditional religions such as Christianity to the museum. As he put it, ${ }^{7}$

It is a common reproach against Christianity that its dogmas are unchanging, while human knowledge is in continual growth. Hence, to unbelievers, we seem to be always engaged in the hopeless task of trying to force the new knowledge into moulds which it has outgrown. I think this feeling alienates the outsider much more than any particular discrepancies between this or that doctrine and this or that scientific theory. ... For him it seems clear that, if our ancestors had known what we know about the universe, Christianity would never have existed at all.

As Christians sought to adapt to the new knowledge, many skeptics held these efforts in contempt; as Lewis put it: ${ }^{8}$

My friend Corineus has advanced the charge that none of us are in fact Christians at all. According to him historic Christianity is something so barbarous that no modern man can really believe it: the moderns who claim to do so are in fact believing a modern system of 
thought which retains the vocabulary of Christianity and exploits the emotions inherited from it while quietly dropping its essential doctrines.

Lewis took it to be his job to defend the essentials of Christian belief, and to show that these essentials wear well as they encounter modern trends of thought.

Lewis portrayed himself as a purveyor of traditional Christianity; but he made his own contributions as well. For example, it has been common in Christian thinking to treat the Bible as a virtually disjointed collection of stories, poems, doctrinal treatises, ethical discourses and so forth. Since about 1990, Christian students of Biblical theology have become more explicitly aware of the over-arching story of the Bible, and of the powerful role that story plays in forming the worldview of a community. As Albert Wolters and Michael Goheen put it, ${ }^{9}$

To miss the grand narrative of Scripture is a serious matter; it is not simply a matter of misinterpreting parts of Scripture. It is matter of being oblivious to which story is shaping our lives. Some story will shape our lives. When the Bible is broken up into little bits and chunks - theological, devotional, spiritual, moral, or worldview bits and chunks - then these bits can be nicely fitted into the reigning story of our own culture with all its idols! One can be theologically orthodox, devotionally pious, morally upright, or maybe even have one's worldview categories straight, and yet be shaped by the idolatrous Western story. The Bible loses its forceful and formative power by being absorbed into a more encompassing secular story.

One way of marking key episodes in this unfolding story is the rubric, "Creation, Fall, Redemption, and Consummation.”10
Lewis was, at least with respect to mainstream Biblical theology, ahead of the game in his attention to the narrative unity of the Christian message. ${ }^{11}$ As early as 1947, in his book Miracles, he was describing world history (which its redemptive component) as "this great story ... a very long story, with a complicated plot."12 In his 1950 essay, "Historicism," he was even more explicit: ${ }^{13}$

For Christianity, ... history is a story with a well-defined plot, pivoted on Creation, Fall, Redemption, and Judgement.

And again, in his Cambridge lectures introducing the medieval picture of the world, published posthumously in 1964 as The Discarded Image, he wrote: 14

History, in a word, was not for them [the Greeks] a story with a plot. The Hebrews, on the other hand, saw their whole past as a revelation of the purposes of Yahweh. Christianity, going on from there, makes world-history in its entirety a single, transcendentally significant, story with a well-defined plot pivoted on Creation, Fall, Redemption, and Judgement.

Many theologians are coming to recognize that their doctrinal formulations must do justice to this narrative structure, and I will return to this theme. For now I simply want to notice that a literary scholar, with no special training in Biblical studies or theology, had seen something that is now acknowledged as old hat. Perhaps his further observations, as I will discuss below, will be likewise fruitful. ${ }^{15}$

\section{Lewis discusses textual features of Genesis}

In his Reflections on the Psalms, Lewis made it clear that he was not what he called a "Fundamentalist"; he did not define the term, but it appears from the context that 
he meant someone with "a prior belief that every sentence of the Old Testament has historical or scientific truth." 16 And Lewis added,

But this [prior belief] I do not hold, any more than St. Jerome did when he said that Moses described Creation "after the manner of a popular poet" (as we should say, mythically) or than Calvin did when he doubted whether the story of Job were history or fiction.

(By the way, this version of "fundamentalism" is often assumed to be entailed by another principle that Schaeffer held to, namely the "inerrancy" of the Bible. No doubt this frequent assumption is due to the fact that plenty of "inerrantists" exist who do indeed fall into that kind of "fundamentalism."17 But the overall principle does not require it. Interestingly enough, Lewis himself touches on some of the linguistic, literary, and philosophical matters that, combined with disciplines such as speech act theory and rhetoric, can provide the tools for articulating a sound notion of Biblical truthfulness - but I shall have to develop that elsewhere. ${ }^{18}$ )

Lewis here refers to Jerome, but no one has located the exact spot in which Jerome makes this claim. The closest source is a passage in the English protoReformer John Colet (1467-1519), who wrote in a letter to one Radulphus: 19

Thus Moses arranges his details in such a way as to give the people a clearer notion, and he does this after the manner of a popular poet, in order that he may the more adapt himself to the spirit of simple rusticity, picturing a succession of things, works, and times, of such a kind as there certainly could not be in the work of so great a Workman.

With this principle in mind, Lewis addresses the possibility that the creation story in Genesis is in some way "derived from earlier Semitic stories which were Pagan and mythical" - a view that had become widely spread by his time, and which was held to discredit Genesis. But Lewis shows his good literary and philosophical sense by first insisting, "We must of course be quite clear what 'derived from' means. Stories do not reproduce their species like mice." He observed that it is persons who do the retelling, and revising of stories, for various ends:

Thus at every step in what is called - a little misleadingly - the "evolution" of a story, a man, all he is and all his attitudes, are involved. And no good work is done anywhere without aid from the Father of Lights. When a series of such re-tellings turns a creation story which at first had almost no religious or metaphysical significance into a story which achieves the idea of true Creation and of a transcendent Creator (as Genesis does), then nothing will make me believe that some of the re-tellers, or some one of them, has not been guided by God.

Hence, although Lewis found much that he deemed poetical, or even mythical, in the Genesis creation story, he was nevertheless willing to attach to it some kind of referent. For example:

We read in Genesis $(2,7)$ that God formed man of the dust and breathed life into him. For all the first writer knew of it, this passage might merely illustrate the survival, even in a truly creational story, of the Pagan inability to conceive true Creation, the savage, pictorial tendency to imagine God making things "out of" something as the potter or the carpenter does. Nevertheless, whether by lucky accident or (as I think) by God's guidance, it embodies a profound principle. For 
in any view man is in one sense made "out of" something else. He is an animal; but an animal called to be, or raised to be, or (if you like) doomed to be, something more than an animal. On the ordinary biological view (what difficulties I have about evolution are not religious) one of the primates is changed so that he becomes man; but he remains still a primate and an animal.

(For some examples of Lewis' delight in seeing humans as a special kind of animal, see below.)

Now, Lewis elsewhere makes it clear that he thought this "changing" of one of the primates to become man was both historical and supernatural. ${ }^{20}$ Thus the poetical or pictorial style of the Genesis story does not prevent it from referring to a real event in the history of the world.

Several ways of qualifying and refining Lewis' observations here immediately come to mind; and as I consider them, I hope that we do not lose sight of the "broadly Lewisian" character of the revision that results.

The first refinement addresses Lewis' interpretation of the phrase in Jerome or Colet, "after the manner of a popular poet" as "mythically," or as "in the form of a folk tale" (in the parallel passage in Miracles). ${ }^{21}$ A chief difficulty in appreciating what Lewis meant here comes from the multiple definitions of the English word "myth," together with the fact that Lewis himself did not consider that word a derogatory categorization. From Lewis' own discussion it appears that he does not intend to suggest that the tale has no historical referentiality; but he is clear that we do not discern whatever referentiality it has by way of a literalistic reading.

For the reader not attuned to all of Lewis' intended nuances, it would be bet- ter to turn to the context of the passage in Colet, the only known source for Lewis' description. Colet's phrases "give the people a clearer notion" and "simple rusticity" point the way; and earlier in the same place, Colet indicates that Moses' object "was not to give to the learned of future generations a scientific statement of the manner and order of the creation of the universe, but to teach a moral lesson to the people whom he was leading out of the bondage and idolatry of Egypt." That is, Colet is not contrasting the literary type of myth or folk tale with a literary type of "history," but rather the popular account with the scientific. The popular account does not even pretend to give the kind of details that the learned scholars seek, about the exact order of events, or the inner workings of the things described. It is content with vivid, pictorial description, and trusts the reader or hearer with the responsibility of using the account properly, namely with allowing the story to capture the imagination and loyalty of the community that owns it.

A further refinement speaks to Lewis' acknowledgement that other ancient Near Eastern origin stories are relevant to the meaning of Genesis. Much has happened in the study of the ancient Near East since Lewis' time. While it was once common to suppose that the Babylonian poem Enuma Elish was the relevant "ancestor" of the Genesis creation story,22 and though some Biblical scholars still think this way, Assyriologists now find in Genesis 1-11 a set of "parallels" to some much older Mesopotamian sources. ${ }^{23}$ To call them "parallels" highlights the problems connected with "derivation"; it allows that Genesis is a response to, a comment upon, or even a refutation of, the Mesopotamian stories, without saying what 
the exact literary relationship is (or even whether specific texts were in mind).

And what do these parallels tell us about the function of Genesis 1-11? The Mesopotamian sources provide what Assyriologist William Hallo calls "prehistory" - the story of the period of human existence before there are any secure written records - and "protohistory" - tales of the earliest stages for which there are records. ${ }^{24}$ Another way to put this is to recognize that these materials provide what we can call the front end of the official Mesopotamian worldview story. Further, it appears that the Mesopotamians aimed to accomplish their purpose by founding their stories on what they thought were actual events, albeit told with a great deal of imagery and symbolism. Thus it is reasonable to take Genesis 1-11 as having a similar purpose in Israel, expecting similar attention to history without undue literalism: these stories explain to ancient Israel where they came from, how things got be the way they are, and why God has called Israel to exist in the first place (to restore the whole of God's world to a condition of "blessing"). 25

Lewis rightly, therefore, recognized the hermeneutical caution that good readers should exercise when approaching Genesis 1-11. His own scholarly studies had made him vividly aware of the problem. In discussing a medieval writer who takes older poetical works too literalistically he says, ${ }^{26}$

The poet is ranked with the scientist as authority for a purely scientific proposition. This astonishing failure or refusal to distinguish - in practice, though not always in theory - between books of different sorts must be borne in mind whenever we are trying to gauge the total effect of an ancient text on its medieval readers.

Lewis speaks further of "the medieval failure to distinguish between writers of wholly different kinds," and gives as an example, "A highly lyrical passage from Job (xxxix. 19-25) is here being turned into a proposition in natural history." 27

A further example of a failure along the lines that Lewis exposes is the effort to describe the "Biblical" picture of the world, as a flat place, possibly disc-shaped, with mountains at the extremities supporting the sky, which is a solid dome with an actual body of water above it; below the land we find an ocean and the subterranean pillars of the earth. Unlike the medievals that Lewis was writing about, scholars' purpose for this description is not to adopt it, but to warrant rejecting the Biblical picture for its primitivity. Such a description appears in, for example, the United Bible Societies' Handbook on Genesis, which makes its appeal to passages such as Psalm 104:2-3, 5-9; 148:4; Job 26:11; 37:18; 38:4-11; Proverbs 8:28-29; Amos 9:6.28 In view of the general sensitivity to linguistic, literary, and rhetorical matters in the UBS series, it is surprising to realize that the list of texts is entirely of poetical passages, with no assessment of the different kinds of texts and what one might have to do to ascertain their presupposed picture of the world. ${ }^{29}$ I wonder what Lewis would say about this way of reading!

Further, Lewis the historian of literature helps us to appreciate that one of the literary techniques at work in Genesis may well be what we call "anachronism," portraying past events in light of the author's and audience's present world. This was certainly a feature of medieval European literature; as Lewis noted, the 
medievals "pictured the whole past in terms of their own age. So did the Elizabethans. ... It is doubtful whether the sense of period is much older than the Waverley novels." 30 This need not detract from the "historicity" of the text, since the text can still refer to actual events without making any kind of strong claim about the details of the characters' circumstances. An example in Genesis would be the term "city" for the very early kind of settlement in Genesis 4:17.

Some may prefer a higher level of literalism in their reading of Genesis than Lewis did, and that preference is legitimately open to discussion. Nevertheless the broadly Lewisian points still stand: first, the possible effect of "pagan" stories on the origin of Genesis need not detract from its inspiration; and second, the possibility (in my mind, the near assurance) of shared motifs and literary conventions with other ancient near Eastern stories need not detract from the referentiality, nor even from the historicity, of the Genesis material - so long as we do not identify historicity with literalism in interpretation. 31

\section{An example: The origin and fall of human beings}

The flow of this essay is headed toward the conclusion that the presence of pictorial material and literary conventions in Genesis 1-11 shows that an approach like Schaeffer's is surely the best way for believers to hold and commend their faith in the larger world.

C. S. Lewis fits into this pattern. For example, he was happy to entertain a variety of scientific-historical scenarios for the origin of humankind, but none of them would be valid if they were to deny the mystery of reason, or any implications that follow from that mystery.
Likewise, these scenarios must not deny the objectivity of ethical judgments.

Consider, for example, his treatment of human origins in the context of his chapter on "The Fall of Man" in The Problem of Pain. ${ }^{32}$ In discussing the Biblical story of Adam and his sin, and the degree to which that event may have affected the rest of us (traditionally the descendants of Adam and Eve), he acknowledges this about "the Fathers" (the leading theologians in the first few Christian centuries):

$$
\begin{aligned}
& \text { Wisely, or foolishly, they believed } \\
& \text { that we were really - and not simp- } \\
& \text { ly by legal fiction - involved in } \\
& \text { Adam's action. }
\end{aligned}
$$

Now, Lewis wanted to do justice to this belief, at the same time as he recognized that 20th century scientific beliefs ran contrary to a literalistic reading. So he set about addressing, with his characteristic clarity, how these two sets of beliefs might relate to one another. "Many people think that this proposition" - that God created Man good, but then Man fell by disobedience - "has been proved false by modern science," with its view that "men have arisen from brutality and savagery."

There seems to me to be a complete confusion here. Brute and savage both belong to that unfortunate class of words which are sometimes used rhetorically, as terms of reproach, and sometimes scientifically, as terms of description; and the pseudo-scientific argument against the Fall depends on a confusion between the usages. If by saying that man rose from brutality you mean simply that man is physically descended from animals, I have no objection. But it does not follow that the further back you go the more brutal - in the sense of wicked or wretched - you will find man to be. 
Lewis insisted, "Science, then, has nothing to say either for or against the doctrine of the Fall," and proceeded to offer a scenario that he thought might be "a not unlikely tale":

For long centuries, God perfected the animal form which was to become the vehicle of humanity and the image of Himself. He gave it hands whose thumb could be applied to each of the fingers, and jaws and teeth and throat capable of articulation, and a brain sufficiently complex to execute all of the material motions whereby rational thought is incarnated. ... Then, in the fullness of time, God caused to descend upon this organism, both on its psychology and physiology, a new kind of consciousness which could say "I" and "me", which could look upon itself as an object, which knew God, which could make judgments of truth, beauty and goodness, and which was so far above time that it could perceive time flowing past. ... We do not know how many of these creatures God made, nor how long they continued in the Paradisal state. But sooner or later they fell. Someone or something whispered that they could become as gods. ... They wanted some corner in the universe of which they could say to God, "This is our business, not yours." But there is no such corner. They wanted to be nouns, but they were, and eternally must be, mere adjectives. We have no idea in what particular act, or series of acts, the selfcontradictory, impossible wish found expression. For all I can see, it might have concerned the literal eating of a fruit, but the question is of no consequence.

It is clear from the context, and from Lewis' other writing, that by "God caused to descend upon this organism, both on its psychology and physiology, a new kind of consciousness" he meant something that was supernatural; as he said in Miracles, "To believe that Nature produced God, or even the human mind, is, as we have seen, absurd." 33 And notice that this "new kind of consciousness" enables the creature to reason about transcendent moral realities, which again cannot be a simple outgrowth of its material capacities.

We might want to revise this scenario in some of its particulars; I have offered my own revisions for it elsewhere, and my result is still "broadly Lewisian." 34 The point here is that, according to Lewis, whatever the details of the story we tell about human origins, there are limits to what we may suggest and still be within the bounds of good critical thinking - which, as Lewis would insist, is necessary if we want to be practicing good science.

What applies to the origin of humankind applies to evolutionary theory in general. Lewis mentioned evolution frequently in his writings, generally to distinguish the scientific theory from the ideological extrapolations some made of it (which he ranked as a "Myth"). But he said a few things about the theory itself. A fair sample would be this: ${ }^{35}$

Again, for the scientist Evolution is a purely biological theorem. It takes over organic life on this planet as a going concern and tries to explain certain changes within that field. It makes no cosmic statements, no metaphysical statements, no eschatological statements. ... It does not in itself explain the origin of organic life, nor of the variations, nor does it discuss the origin and validity of reason. It may well tell you how the brain, through which reason now operates, arose, but that is a different matter. Still less does it even attempt to tell you 
how the universe as a whole arose, or what it is, or whither it is tending. But the Myth knows none of these reticences. ... 'Evolution' (as the Myth understands it) is the formula of all existence.

The kind of evolutionary theory that did not bother Lewis theologically "does not in itself explain the origin of organic life, nor of the variations, nor ... of reason"; that is, it does not insist beforehand that we may only allow a purely naturalistic scenario for the whole development of life (though he has not ruled that out). ${ }^{36}$

Nominally, at least, some leading evolutionary biologists support Lewis on this. For example, D. M. S. Watson (1886-1973), Professor of Zoology and Comparative Anatomy at University College, London (1921-1951), acknowledged: "But whilst the fact of evolution is accepted by every biologist the mode in which it has occurred and the mechanism by which it has been brought about are still disputable." 37 The National Science Teachers Association (NSTA) says something very similar:

There is no longer a debate among scientists about whether evolution has taken place. There is considerable debate about how evolution has taken place: What are the processes and mechanisms producing change, and what has happened specifically during the history of the universe?

Even though these statements sensibly refuse to decide ahead of time what kinds of factors can be involved, other statements are emphatic in ruling some things out. The National Association of Biology Teachers (NABT) insists: ${ }^{38}$

Evolutionary biology rests on the same scientific methodologies the rest of science uses, appealing only to natural events and processes to describe and explain phenomena in the natural world. Science teachers must reject calls to account for the diversity of life or describe the mechanisms of evolution by invoking non-naturalistic or supernatural notions.

(I do not suggest here that Lewis thought that "non-naturalistic" notions must be involved in any extensive fashion, nor whether any of these would be readily perceptible to human students, nor even whether it was appropriate for him to have much of an opinion - except, of course, in the origin of humankind.)

It is therefore reasonable, in light of what kind of text Genesis 1-11 is, first, to refuse to dictate to the paleontologist what he or she may find in the fossils, or a geneticist in the genome. At the same time, when that geneticist or paleontologist wants to try to put those findings together into larger theories that tell the human story, then that person is reasoning as a human being, and his or her reasoning must comply with good reasoning. As Lewis wrote in another context, 39

Now I dread specialists in power because they are specialists speaking outside their special subjects. Let scientists tell us about sciences. But government involves questions about the good for man and justice, and what things are worth having at what price; and on these a scientific training gives a man's opinion no added value.

A white lab coat does not confer a privileged status to one's dicta in every subject!

Consider some more of the features that Lewis touches on, which distinguish humans from the rest of the animals. The motivation for science itself is distinctively human: "One of the things that distinguishes man from the other animals is 
that he wants to know things, wants to find out what reality is like, simply for the sake of knowing." 40 Human friendship is another feature that resists explanation purely in terms of natural development of animal capacities: ${ }^{41}$

Friendship is - in a sense not at all derogatory to it - the least natural of loves; the least instinctive, organic, biological, gregarious and necessary. ... We can live and breed without Friendship. The species, biologically considered, has no need of it. ...

[Friendship] has no survival value; rather it is one of those things which give value to survival.

Some researchers have indeed tried to argue that human friendship is continuous with some aspects of animal behavior, but they must rest their argument on defining friendship down. A 2003 survey article in Science News, entitled "Beast buddies," concludes: "Harder to understand though, according to Silk, are the bonds so close and widespread in Homo sapiens. She says, 'None of our models of reciprocity [among nonhuman animals] can accommodate the psychology of human friendship." 42

Humans even carry out their romantic loves in a way that shows both their animality and their distinctiveness: 43

For I can hardly help regarding it as one of God's jokes that a passion so soaring, so apparently transcendent, as Eros, should thus be linked in incongruous symbiosis with a bodily appetite which, like any other appetite, tactlessly reveals its connections with such mundane factors as weather, health, diet, circulation, and digestion. ... It is a continual demonstration of the truth that we are composite creatures, rational animals, akin on one side to the angels, on the other to tom- cats. It is a bad thing not to be able to take a joke.

The other animals are uniformly serious!

Lewis would have us believe that there is something fundamentally unreasonable in the insistence (such as the NABT has apparently made) that even humankind arose by a purely natural process; and since it is unreasonable, it is bad scientific history. And Lewis had undoubtedly met people who made just such an insistence, even in the name of "science." Of them he said, ${ }^{4}$

They ask me at the same moment to accept a conclusion and to discredit the only testimony on which the conclusion can be based. The difficulty is to me a fatal one; and the fact that when you put it to many scientists, far from having an answer, they seem not even to understand what the difficulty is, assures me that I have not found a mare's nest but detected a radical disease in their whole mode of thought from the very beginning.

To see how Lewis' approach helps us to face contemporary challenges, consider this example. Anthony Cashmore is a professor of biology at the University of Pennsylvania, specializing in "the mechanism by which plants respond to light." 45 He was elected to the National Academy of Sciences in 2003, and the Proceedings of the National Academy of Sciences published his inaugural article, "The Lucretian swerve: The biological basis of human behavior and the criminal justice system," in 2010.46 Cashmore aims to show that, since human behavior is the product of genes, environment, and "stochastic" factors (that is, they are probabilistic), therefore there is no such thing as free will. This in turn means that "individuals cannot logically be held respon- 
sible for their behavior"; which then leads to Cashmore's purpose for writing, namely a proposal to reform the American criminal justice system.

In making the argument about how the biological factors determine behavior, Cashmore does cite a few studies in cognitive science, regarding the relationship between measurable brain activity and human choices. He does not claim that anyone actually understands the brain processes, or what consciousness is; he rather expects that at some point we will have a full explanation for how it arises from the chemical properties of the nervous system. He nevertheless insists, "as living systems we are nothing more than a bag of chemicals"; "not only do we have no more free will than a fly or a bacterium, in actuality we have no more free will than a bowl of sugar. The laws of nature are uniform throughout, and these laws do not accommodate the concept of free will."

Because "progress in understanding the chemical basis of behavior will make it increasingly untenable to retain a belief in the concept of free will," therefore "it is time for the legal system to confront this reality." All of the reforms he proposes stem from "the elimination of the illogical concept that individuals are in control of their behavior in a manner that is something other than a reflection of their genetic makeup and their environmental history," and this will "hopefully minimize the retributive aspect of criminal law." Persons convicted of crimes will then be given the appropriate psychiatric help (as specified by a "court-appointed panel of experts").

There is much to say about the overall logic of Cashmore's argument, and many of the details as well. For now I will content myself with observing that Lewis would surely point out that Cashmore, in declaring our thoughts to be merely a biological phenomenon, has undercut anyone's right to believe such a claim. Cashmore seems to have taken it as fundamental to science that we must seek purely material and, apparently, reductionistic, explanations for everything.

Lewis, who wrote, “A man's rational thinking is just so much of his share in eternal Reason as the state of his brain allows to become operative," 47 would not be surprised at the close connection between brain activity and decisions, although he would likely also point out how little these findings actually do explain. He would surely also note what problems we make for ourselves if we suppose that it is even reasonable to posit that chemical events in the brain, strictly speaking, cause thoughts or choices.

Further, we recognize that free will and moral responsibility are parts of a larger realm of discourse, in which there is some transcendent norm that we are obligated to comply with. And Cashmore has not evaded such transcendence. Why does he not suggest that we simply eliminate those who commit crimes - whether from the population, or at least from the gene pool (say, by sterilization)? Surely it is because he sees as clearly as anyone else that we should not do such horrors to our fellow humans. Why does he think we ought to restructure our criminal justice system? Is it not because he considers it unjust to punish people for things for which they are not responsible? And who gets to choose these panels of experts, what kind of decision-making does he expect from them, and to whom will they be accountable? Will they be "wrong" if they accept bribes or other favors? I must believe that Cashmore expects everyone to behave with the utmost honesty and 
fairness, and that they are blameworthy if they do not. And even to make the case for something, to try to persuade us that it is true, is in effect to insist that the readers ought to believe it, and are culpable if they do not. 48

It is to Cashmore's credit that he commits these inconsistencies: they are his humanity breaking through. As Lewis put it, "Holding a philosophy which excludes humanity, they yet remain human.... They know far better than they think they know." 49 We might suspect that Lewis would add, along with his Professor Digory Kirke, “Logic! Why don't they teach logic at these schools?" 50

\section{Objection: These "adjustments" take leave of the Biblical presentation}

I have already cited a passage from Lewis where he imagined his friend Corineus objecting to a project such as I have discussed here, namely that we are no longer talking about the Biblical world (see $\$ 2$ above).

Indeed, in words that oddly echo Corineus, the Biblical scholar Peter Enns has made exactly this objection to my own study on Adam and Eve: 51

Collins's synthesis requires an ad hoc hybrid "Adam" who was "first man" in the sense of being either a specially chosen hominid or a larger tribe of early hominids (Collins is careful not to commit himself to either option). ... Further, this type of hybrid "Adam," clearly driven by the need to account for an evolutionary model, is not the Adam of the biblical authors.

For now I leave aside the question of whether Enns has presented and analyzed my argument carefully (I think he clearly did not), because I am not aiming to defend the specifics of my own work here, except insofar as I am "broadly Lewi- sian." 52 I will instead focus our attention on his words, not the Adam of the biblical authors, with its echo of Corineus.

How does Lewis help us think through such an objection? First, Lewis has reminded us that the material in Genesis 1-11 contains a good deal of pictorial description: and this means, both that we must be careful of undue literalism, and that the material can still have a referent. Enns seems to be suggesting that only a literalistic reading of the Genesis material is true to the Bible writers on their own terms, and that any effort to relate that to "science" departs from the Bible writers altogether (a departure he advocates). .53

The British New Testament scholar N. T. Wright seems to understand things better than Enns when he discusses the apostle Paul's use of Adam in Romans 5:54

Paul clearly believed that there had been a single first pair, whose male, Adam, had been given a commandment and had broken it. Paul was, we may be sure, aware of what we would call mythical or metaphorical dimensions to the story, but he would not have regarded these as throwing doubt on the existence, and primal sin, of the first historical pair. Our knowledge of early anthropology is sketchy, to put it mildly. Each time another very early skull is dug up the newspapers exclaim over the discovery of the first human beings; we have consigned Adam and Eve entirely to the world of mythology, but we are still looking for their replacements. What "sin" would have looked like in the early dawn of the buman race it is impossible to say; but the turning away from open and obedient relationship with the loving creator, and the turning toward that which, though beautiful and enticing, is not God, is such a many-sided phenomenon that it is 
not hard to envisage it at any stage of anthropoid development. The general popular belief that the early stories of Genesis were straightforwardly disproved by Charles Darwin is of course nonsense, however many times it is reinforced in contemporary myth-making. Things are just not that simple, in biblical theology or science.

Lewis deals with the ideas at the base of this objection: ${ }^{55}$

Remembering, as I do, from within, the attitude of the impatient sceptic, I realize very well how he is forearmed against anything I might say for the rest of this chapter. "I know exactly what this man is going to do," he murmurs. "He is going to start explaining all these mythological statements away ... ." ... I freely admit that "modernist" Christianity has constantly played just the game of which the impatient sceptic accuses it. But I also think there is a kind of explaining which is not explaining away. ... I am going to distinguish what I regard as the "core" or "real meaning" of the doctrines from that in their expression which I regard as inessential and possibly even changed without damage.

Lewis draws a distinction between the "core" of a Christian doctrine and the particular form by which some people might picture the relevant events, and he reminds us, "Christianity is not to be judged from the fancies of children any more than medicine from the ideas of the little girl who believed in horrid red things." ${ }_{56}$

He then asks us to imagine a scenario: 57

We can suppose a Galilean peasant who thought that Christ had literally and physically "sat down at the right hand of the Father." If such a man had then gone to
Alexandria and had a philosophical education he would have discovered that the Father had no right hand and did not sit on a throne... Even if it could be shown, then, that the early Christians accepted their imagery literally, this would not mean that we are justified in relegating their doctrines as a whole to the lumber room. Whether they actually did, is another matter. The difficulty here is that they were not writing as philosophers to satisfy speculative curiosity about the nature of God and of the universe. ... Hence the sort of question we are now considering is never raised by the New Testament writers. When once it is raised, Christianity decides quite clearly that the naif images are false. ... We do not find similar statements in the New Testament, because the issue has not yet been made explicit: but we do find statements which make it certain how that issue will be decided when once it becomes explicit.

Or, as he puts it in another place, 58

The answer is that the alternative we are offering [the early Christians] was probably never present to their minds at all. As soon as it was present, we know quite well which side of the fence they came down on....

The earliest Christians were not so much like a man who mistakes the shell for the kernel as like a man carrying a nut which he hasn't yet cracked. The moment it is cracked, he knows which part to throw away. Till then he holds on to the nut, not because he is a fool but because he isn't.

Besides Alexandrian analysis, what sorts of principles do we have that can guide us, ensuring that we are keeping the kernel? One overlooked factor in Lewis that I have alluded to is the notion of the over- 
arching storyline of the Bible. The story begins with a transcendent God who made a good world, with its human inhabitants morally innocent. By some sort of disobedience they pulled themselves and their offspring astray from God's good plan, and God's activity is thereafter redemptive - that is, he is constantly aiming to provide "forgiveness for having broken, and supernatural help towards keeping, that law," that universal law embedded in the good creation..$^{59}$ The freedoms leave some room for discussion over just what kinds of scenarios we will be intellectually satisfied with; but the shape of the story puts a limit on our speculations: we want to be sure that we are still telling the same story. This, by the way, is why we should not take Lewis' image of the kernel and shell too strictly: that is, the Biblical way of describing things retains its value as the proper way to envision the events and scenery, because that imagery shapes our attitudes. Hence, we are not free to "throw it away" in every sense, and Lewis himself did not.

Corineus' objection, then - as exemp- lified by Peter Enns - stems from a drastic oversimplification, and thus from actual misunderstanding.

\section{Conclusions}

C. S. Lewis, Francis Schaeffer, and Jerram Barrs have shown us how the Biblical story, sometimes summarized as Creation, Fall, Redemption, and Consummation, rings true: it actually accounts for what we find in ourselves and in the world. That story is, in fact, the true Big Story that makes sense of our lives. I admire the passion with which these men have sought to bring the truth of this Big Story to bear on a wide range of human activities - indeed, on all of life.

Such an endeavor will meet difficulties, and our faith obligates us to make our best effort to address these difficulties with full intellectual rigor and honesty. By combining the profound insights of Lewis and Schaeffer into a sensible program of "freedoms and limitations" we have the tools we need for responsible and faithful discussions of our origins.

\footnotetext{
Notes

1 [Eds.] This tribute to Jerram Barrs was originally published in Doug Serven (ed.) Firstfruits of a New Creation. Essays in Honor of Jerram Barrs (Oklahoma City, OK: White Blackbird Books, 2018), pp. 183-208. It is re-published here with the kind permission of both author, editor, and publisher.

2 [Eds.] See https://www.covenantseminary.edu/francis-schaeffer-institute/.

3 [Eds.] Jerram Barrs is Professor of Christian Studies \& Contemporary Culture, Senior Scholar-in-Residence of the Francis Schaeffer Institute, and Francis Schaeffer Chair of Apologetics at Covenant Theological Seminary. See further https://www.covenantseminary.edu/faculty/jerram-barrs/.

4 Francis A. Schaeffer, No Final Conflict (London: Hodder and Stoughton / Downers Grove, IL: Inter Varsity Press, 1975), ch. 3. This appears also in Francis A. Schaeffer, The Complete Works of Francis A. Schaeffer (Westchester, IL: Crossway, 1982), vol. 2.

5 Robert Letham uses this expression in his The Westminster Assembly: Reading its theology in historical context (Phillipsburg, NJ: P \& R, 2009), 3, 176, 182 ("The Assembly was not partisan body within the boundaries of its generic Calvinism, but allowed differing views to coexist.”), 365. Letham drew on Benjamin Warfield, The Westminster Assembly and its Work (New York: Oxford University Press, 1934), 136:

"obviously it was generic Calvinism they were intent on asserting and not any particular variety of it."

6 Although I have long thought along these lines, I attribute the delightful term "broadly Lewisian" to Steven Jon James Lovell, Philosophical Themes from C. S. Lewis (University of Sheffield PhD, 2003), e.g. p. 10.

7 C. S. Lewis, God in the Dock: Essays on theology and ethics (Walter Hooper, ed.; Grand Rapids:

Eerdmans, 1970), 38 ("Dogma and the universe," 1943). Since many of Lewis' works appear in several editions, with different page numbers (and some of these are online), and since the collections of essays gather things written at different times, my convention for citing Lewis is the following: the books I will cite from the edition I own, but also with the chapter or section number; the essays I will cite from the collection, but also with the title and (probable) date.
} 
8 Lewis, God in the Dock, 63 ("Myth became fact," 1944).

9 Albert M. Wolters and Michael W. Goheen, Creation Regained: Biblical Basics for a Reformational Worldview 2nd ed. (Grand Rapids: Eerdmans, 2005), 125.

10 Wolters and Goheen offer the idea of a play in six acts, Creation, then Fall, then Israel, then Jesus in the Gospels, then the post-Easter Church, and then the consummation - thus splitting Redemption up into three parts.

11 One can find various titles such as Abraham Oakes, A short essay on the creation, fall, and redemption of man (London, 1750), and T. R. Birks, The Difficulties Of Belief In Connexion With The Creation And The Fall, Redemption And Judgment (London, 1876). One might further find this narrative structure to underlie the famous "fourfold state of man" of authors such as Thomas Boston; but the influence of this structure on Biblical studies and theology seems (to me at least) small. Readers of the Greek Christian theologian Athanasius (296-373) will recognize that he has structured his two major apologetic works, Against the Heathen and On the Incarnation of the Word of God, around just this storyline.

12 C. S. Lewis, Miracles: A preliminary study (1 ${ }^{\text {st }}$ edition; London: Geoffrey Bles, 1947), 119-20 (ch. 12); (2 ${ }^{\text {nd }}$ edition; New York: Macmillan, 1960), $98-99$ (the edition I usually cite).

13 C. S. Lewis, "Historicism," in Christian Reflections (Walter Hooper, ed.; Grand Rapids: Eerdmans, 1967), $100-113$, at 103 .

14 C. S. Lewis, The Discarded Image: An introduction to Medieval and Renaissance literature (Cambridge: Cambridge University Press, 1964), 174. See also the incidental mention earlier in the book: "the Christian doctrines of man's creation, fall, redemption, and resurrection" (28).

15 For more general reflections on aspects of Lewis' thought, see my essay, "A peculiar clarity: How C. S. Lewis can help us think about faith and science," in John G. West, ed., The Magician's Twin: C. S. Lewis on Science, Scientism, and Society (Seattle: Discovery Institute Press, 2012), 69-106.

16 Lewis, Reflections on the Psalms (London: Geoffrey Bles, 1958), 109 (ch. 11).

17 For a similar difficulty, cf. Lesslie Newbigin, Proper Confidence: Faith, doubt, and certainty in Christian discipleship (Grand Rapids: Eerdmans, 1995), 84-92-a difficulty no doubt due both to Newbigin's contact with "fundamentalists" of this type, and to the general obscurity (or even non-availability) of a more sophisticated approach.

18 I do have such a work in preparation. See further, for example, the essays in D. A. Carson and John D. Woodbridge, eds., Hermeneutics, Authority and Canon (Leicester: Inter-Varsity Press, 1986).

19 From his second letter to Radulphus (1497); English translation from Frederick Seebohm, The Oxford Reformers (London: Longmans, Green, \& Co., 1869), 51 (italics original). Another translation, with the Latin original, appears in J. H. Lupton, ed., Letters to Radulphus on the Mosaic Account of the Creation, Together with Other Treatises, by John Colet, M.A. (London: George Bell, 1876), 9-10. The wording quoted suggests that Lewis had read the Seebohm edition of the letters (Lupton's rendering is "after the manner of some popular poet," which is also close). It is possible that Lewis mistakenly attributed this to Jerome, since he is well-known to have quoted often from memory - see Walter Hooper's "Preface" to Lewis, Selected Literary Essays (Walter Hooper, ed.; Cambridge: Cambridge University Press, 1969), xvii. But it is also possible that Colet did actually derive this view from Jerome, as he did so many other views. In the first letter to Radulphus, Colet had mentioned Jerome as a careful scholar familiar with the original Hebrew. Credit for tracking down this reference goes to the blog post and comments at

alltheblognamesalreadytaken.wordpress.com/2008/05/29/cs-lewis-and-st-jerome/.

20 This point follows from Lewis' argument in his Miracles, regarding the special status of mind, which cannot be explained as merely the material operations of the brain. See also his Problem of Pain (London: Geoffrey Bles, 1940), ch. 5.

21 Lewis, Miracles, 33 (ch. 4); God in the Dock, 42 ("Dogma and the universe," 1943).

22 See the discussion in Alexander Heidel, The Babylonian Genesis (Chicago: University of Chicago Press, 1951) - a book that addresses issues that were current in Lewis' time.

23 For discussion and documentation, see my Did Adam and Eve Really Exist? Who they were and why you should care (Wheaton, IL: Crossway, 2011), Appendix 1.

24 William W. Hallo, "Part 1: Mesopotamia and the Asiatic Near East," in William W. Hallo and William K. Simpson, eds., The Ancient Near East: A history (Fort Worth, TX: Harcourt Brace College Publishers, 1998), $3-181$, at 25 .

25 I make these points more fully in in chapter 2 and Appendix 1 of Did Adam and Eve Really Exist? An example of missing this point comes from Daniel Harlow, "After Adam: Reading Genesis in an age of evolutionary science," Perspectives on Science and Christian Faith 62.3 (2010): 179-95; at 185-87, Harlow notices symbolic and pictorial elements in both Genesis and the Mesopotamian sources, and pronounces them both unhistorical. He is confusing historicity with a literalistic scheme of interpretation, without argument.

26 Lewis, Discarded Image, 31. 
27 Lewis, Discarded Image, 147-48.

28 William D. Reyburn and Euan McG. Fry, Handbook on Genesis (New York: United Bible Societies, 1997), 27.

29 Likewise, in what is actually a good book (which I have commended), Davis Young and Ralph Stearley, The Bible, Rocks and Time (Downers Grove: InterVarsity, 2008), dismiss appeal to phenomenal language as an "attempt to avoid the force of the [Genesis] statement" (207), apparently unaware of all the linguistic, literary, and rhetorical issues they have swept under the rug.

30 Lewis, Discarded Image, 183. "The Waverley novels" refers to a class of historical fiction that began in the early $19^{\text {th }}$ century (as in Sir Walter Scott's Waverley, 1814).

31 For more detail, see my Did Adam and Eve Really Exist, $\$ 2$ b. I also employ a number of Lewisian and Schaefferian ideas in my contributions to Matthew Barrett and Ardel Canaday, eds., Four Views on the Historical Adam (Grand Rapids: Zondervan, 2013) - not only in my chapter, but also in my comments on the other contributions.

32 Lewis, Problem of Pain, ch. 5.

33 Lewis, Miracles, 32 (ch. 5).

34 See my discussion in my Did Adam and Eve Really Exist, $\$ 5$ d; I propose my own "freedoms and limitations" in $\$ 5 \mathrm{c}$. In my discussion of Lewis, I draw attention to his bafflement over the solidarity concept that underlies the Biblical picture. Hence it fascinated me to discover after my book's publication that Lewis continued to wish for greater light on this topic: in a letter written in 1951, more than 10 years after The Problem of Pain, he wishes he had known more about how the notion of "members of one another" works; letter, 12 September 1951, cited in Richard Purtill, C. S. Lewis' Case for the Christian Faith (San Francisco: Ignatius, 2004 [1985]), 56. This idea is part of what New Testament scholars now call "interchange," and it is part of the larger question of corporate solidarity among the people of God. 35 Lewis, Christian Reflections, 86 ("The funeral of a great myth," ca. 1945). Lewis may very well be reflecting a comment by G. K. Chesterton, whom he admired: "No philosopher denies that a mystery still attaches to the two great transitions: the origin of the universe itself and the origin of the principle of life itself. Most philosophers have the enlightenment to add that a third mystery attaches to the origin of man himself. In other words, a third bridge was built across a third abyss of the unthinkable when there came into the world what we call reason and what we call will," in The Everlasting Man (Garden City: Doubleday, 1955 [1925]), 27. A work that Lewis praised, Arthur James Balfour, Theism and Humanism (New York: Hodder \& Stoughton, 1915), makes this point as well. And, interestingly enough in view of Schaeffer's connection to "Old Princeton" Seminary, David Livingstone has shown that Benjamin Warfield wound up with a very similar approach to evolution; see Livingstone, Darwin's Forgotten Defenders (Grand Rapids: Eerdmans, 1987). Hence Lewis' reservations about what natural "evolution" can accomplish resonate with Schaeffer's freedoms and limitations cited at the head of this essay.

36 J. B. S. Haldane, whom Lewis mentioned often, certainly did want to claim that evolutionary biology ruled out any possibility of conventional theistic religion being true. He states this plainly in his essays "Darwinism today," "When I am dead," and "Science and theology as art forms" in Possible Worlds and Other Essays (New Brunswick, NJ: Transaction Publishers, 2002 [1927]); see further Gordon McOuat and Mary P. Winsor, “J. B. S. Haldane's Darwinism in its religious context," British Journal for the History of Science 28.2 (1995): 227-31.

37 Watson, "Adaptation," Report of the Ninety-Seventh Meeting British Association for the Advancement of Science (London: Office of the British Association, 1929), 88-99, at 88.

38 These two statements were accessed in January of 2016: "NSTA Position Statement: The Teaching of Evolution," 2003, http://www.nsta.org/about/positions/evolution.aspx “NABT Position Statement on Teaching Evolution," adopted in 1995 and modified in 1997, 2000, 2004, 2008, and 2011, http://www.nabt.org/websites/institution/?p=92. (Earlier versions held that "natural selection ... has no specific direction or goal," but this has been removed - so at least a teleological reading of the whole process is allowed for.)

39 Lewis, God in the Dock, 315 ("Is progress possible? Willing slaves of the welfare state," 1958).

40 Lewis, God in the Dock, 108 ("Man or rabbit?," 1946).

41 Lewis, The Four Loves (London: Geoffrey Bles, 1960), 70, 84 (ch. 4). In the same chapter Lewis observes, "To those-and they are now the majority - who see human life merely as a development and complication of animal life all forms of behaviour which cannot produce certificates of an animal origin and of survival value are suspect" (71).

42 Susan Milius, “Beast buddies,” Science News 164:18 (November 1, 2003), 282-84.

43 Lewis, The Four Loves, 116 (ch. 5).

44 Lewis, The Weight of Glory and Other Addresses (Walter Hooper, ed.; New York: Simon \& Schuster, 1996 [1980]), 103 ("Is theology poetry," 1944); cf. Christian Reflections, 89 ("Funeral of a great myth," ca. 1945). See also God in the Dock, 135 ("Religion without dogma?," 1946), where Lewis notes that there are different levels of openness to religion in the different scientific disciplines: "It is as their subject matter comes nearer to man himself that their anti-religious bias hardens." 


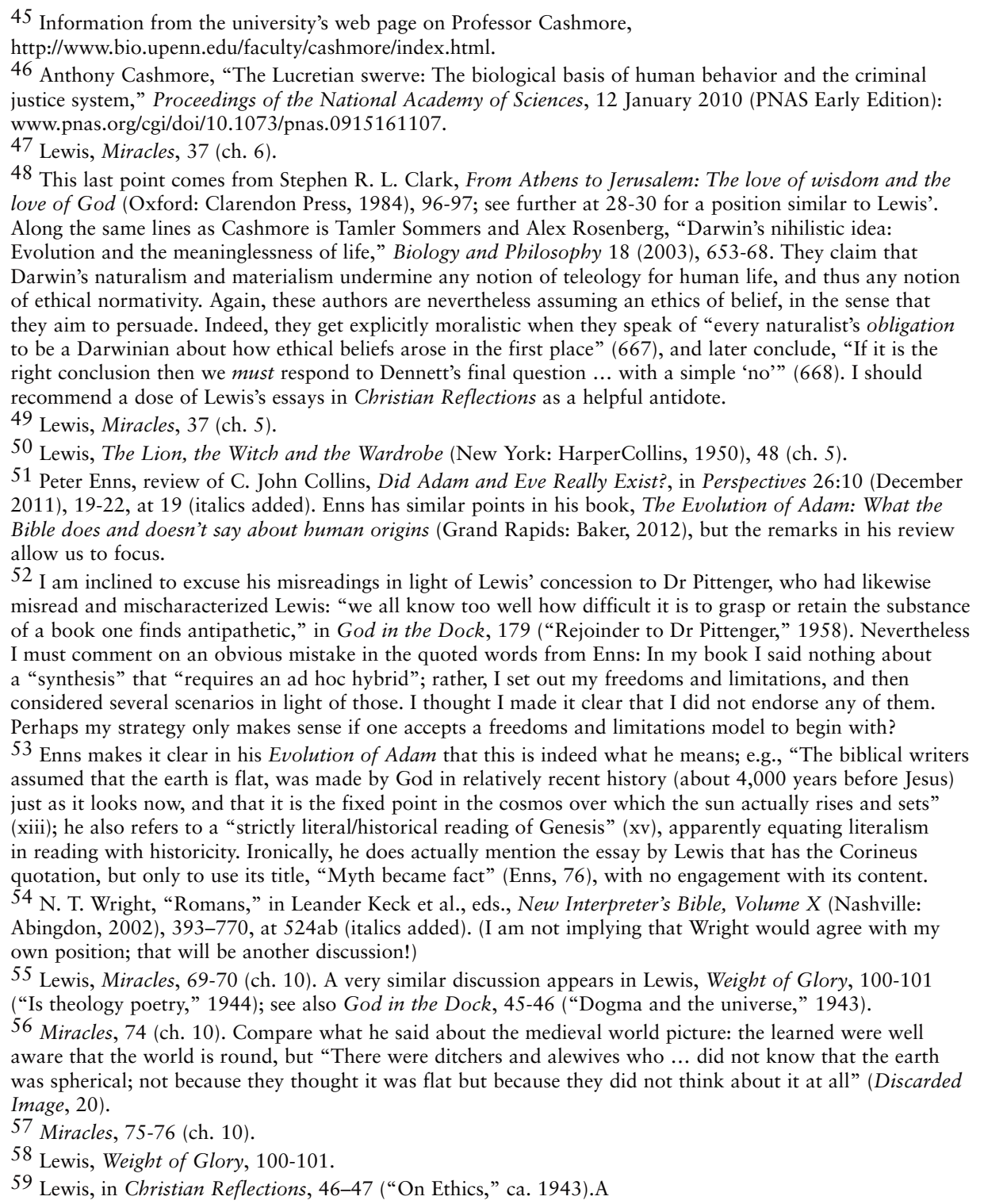


A Nordic open access journal in Theology, Philosophy and Culture

Published by NLA University College - in partnership with Johannelund School of Theology

Available at www.theofilos.no

\title{
Exploring Genesis 1-3 as a True Worldview Story: \\ Reading alongside C. S. Lewis, Francis A. Schaeffer, and C. John Collins
}

\author{
Lars Dahle \\ Associate Professor in Systematic Theology \\ NLA University College, Kristiansand, Norway \\ lars.dable@nla.no \\ Bjørn Hinderaker \\ Assistant Professor in Communication and Worldviews \\ NLA University College, Kristiansand, Norway \\ bjorn.hinderaker@nla.no
}

I still think that a 'broadly Lewisian' and 'broadly Schaefferian' tack when it comes to

Genesis will provide us with the intellectually and morally robust tools we need for bringing the message of Genesis to each culture.

$$
\text { C. John ("Jack") Collins" }
$$

As co-editors of this Theofilos Supplement issue, we are delighted that the issue contains such a wealth of valuable contributions. As theologians and apologists, we find Jack Collins' approach promising, not the least because he draws on key insights from the two influential 20th century apologists C. S. Lewis and Francis A. Schaeffer ${ }^{1}$ in his exposition and application of Genesis $1-3$ as a true worldview story.

We have a threefold intention with this article. First, to introduce some key contributions from Schaeffer, Lewis and Collins, largely in their own words. Secondly, to indicate why we find their contributions attractive and worthy of further explorations. Thirdly, in view of these contributions, to offer some brief, final reflections on how to understand Genesis 1-3 in worldview terms and how to integrate and apply this worldview story in our apologetics.

\section{S. Lewis on grasping a story and the Story}

\section{Approaching any story with Lewis}

As a Genesis specialist with a keen interest in issues of faith and science, Jack Collins was well suited to serve as Research Fellow at the Creation Project at the Carl F. Henry Center for Theological Understanding. This project is a major initiative "designed to nurture evangelical

\footnotetext{
* Lewis and Schaeffer were two of the most influential Christian apologists in the 20th Century in their own right. We have a special affinity to these two apologists in our academic Communication and Worldviews programme (in Norwegian: "kommunikasjon og livssyn"). This is due both to their foundational theological orientation, their significant - and quite different - contributions to Christian apologetics, and their deep understanding of the importance of worldviews in Christian apologetics.
} 
engagement with the doctrine of creation in all of its historical, theological, and scientific complexity."2 Collins' research resulted in the publication of a fascinating monograph entitled Reading Genesis Well: Navigating History, Poetry, Science, and Truth in Genesis 1-11 (2018)

In an interesting interview with Bible Gateway, Collins explains how he discovered his starting point in this study in C. S. Lewis' professional writings on English language and literature:

Lewis' professional writings display an intuitive grasp of disciplines that are nowadays held separate, such as rhetoric, literary interpretation, and linguistics - and these disciplines can, if used wisely, help us to make our reading more careful. In Lewis' intuitions we see the benefits of not separating what God has joined together, and that's what I've put to work here...

Lewis began one of his books this way: "The first qualification for judging any piece of workmanship from a corkscrew to a cathedral is to know what it is - what it was intended to do and how it is meant to be used." 3

Straightaway, Lewis has drawn our attention to three aspects of a work of literary craftsmanship:

1) What it is: issues of things like "genre," style, and register; What is the relation of literary form and the content?

2) What it was intended to do: What effect does the work aim to produce in its users?

3) How it is meant to be used: What kind of users are envisioned by the work, what knowledge and beliefs do they share with the author, what kind of social setting is the normal locus of use? 4

As we will see below, Collins shows how these three foundational questions may be highly significant for a deeper and more balanced reading of the early chapters of Genesis.

\section{Approaching the biblical Story with Lewis}

We may connect these literary insights from Lewis to his well-known emphasis on the deeper theological significance of 'mythical' stories. As Alister McGrath points out, this was an insight that Lewis gained from his friend J. R. R. Tolkien:

[A conversation with Tolkien in
1931] helped Lewis realize that
myths in the technical literary sense
of the term - were 'profound and
suggestive of meanings' that lay be-
yond his grasp, so that he was
unable to state in plain language
'what it meant'.

For Lewis, a myth is a story that evokes awe, enchantment, and inspiration, and conveys or embodies an imaginative expression of the deepest meanings of life. Lewis came to see that the story of Christ was a "true myth" - that is to say, a myth that functions in the same manner as other myths yet really happened. Christianity possessed the literary form of a myth, with the critical difference that it was true. The story of Christ is thus to be understood as 'God's myth', whereas the great pagan narratives are 'men's myths'. ${ }^{5}$

McGrath continues by clarifying how Lewis uses the term 'myth':

Many, particularly within the American evangelical community, misunderstand Lewis at this point, believing that his use of the term 'myth' implies that Christianity is fictional or false. As recent scholarship has made clear, however, a "myth" is ultimately a worldview that is presented in the form of a narrative. ${ }^{6}$

This biblical story makes sense of our glo- 
bal story as a common humanity. In Lewis' own words: "Christianity, going on from [the Hebrew Bible], makes world history in its entirety a single, transcendentally significant, story with a well-defined plot pivoted on Creation, Fall, Redemption, and Judgement."7 Thus, according to Lewis, the Bible provides us with a coherent worldview story from creation and fall, towards Christ and the ultimate consummation.

\section{Appreciating an imaginative retelling of the Story with Lewis}

We will now highlight two examples of how Lewis uses a 'mythical' retelling of the biblical Story, as his creative way of communicating rich biblical truth.

The first one is the imaginative re-telling of the creation story in the famous Narnia story The Magician's Nephew:

In the darkness something was happening at last. A voice had begun to sing. It was very far away and Digory found it hard to decide from what direction it was coming. Sometimes it seemed to come from all directions at once. Sometimes he almost thought it was coming out of the earth beneath them. Its lower notes were deep enough to be the voice of the earth herself. There were no words. There was hardly even a tune. But it was, beyond comparison, the most beautiful noise he had ever heard. It was so beautiful he could hardly bear it. The horse seemed to like it too: he gave the sort of whinny a horse would give if, after years of being a cab-horse, it found itself back in the old field where it had played as a foal, and saw someone whom it remembered and loved coming across the field to bring it a lump of sugar. "Gawd!" said the Cabby. "Ain't it lovely?" Then two wonders happened at the same mo- ment. One was that the voice was suddenly joined by other voices; more voices than you could possibly count. They were in harmony with it, but far higher up the scale: cold, tingling, silvery voices. The second wonder was that the blackness overhead, all at once, was blazing with stars. They didn't come out gently one by one, as they do on a summer evening. One moment there had been nothing but darkness; next moment a thousand, thousand points of light leaped out - single stars, constellations, and planets, brighter and bigger than any in our world. There were no clouds. The new stars and the new voices began at exactly the same time. If you had seen and heard it, as Digory did, you would have felt quite certain that it was the stars themselves who were singing, and that it was the First Voice, the deep one, which had made them appear and made them sing... 8

... The Lion was pacing to and fro about that empty land and singing his new song. It was softer and more lilting than the song by which he had called up the stars and the sun; a gentle, rippling music. And as he walked and sang the valley grew green with grass. It spread out from the Lion like a pool. It ran up the sides of the little hills like a wave. In a few minutes it was creeping up the lower slopes of the distant mountains, making that young world every moment softer. The light wind could now be heard ruffling the grass. Soon there were other things besides grass. The higher slopes grew dark with heather. Patches of rougher and more bristling green appeared in the valley. Digory did not know what they were until one began coming up quite close to him. It was a little, spiky thing that grew out dozens of arms and covered these arms with 
green and grew larger at the rate of about an inch every two seconds. There were dozens of these things all round him now. When they were nearly as tall as himself, he saw what they were. "Trees!" he exclaimed." 9

This beautiful, re-imagining of the Genesis 1 story fills us with wonder and joy, if we let it speak to us on a deeper level.

The second example of Lewis' retelling of the Genesis 1-3 story is from Pereland$\mathrm{ra}$, the second book in his science fiction trilogy. It relates how temptation is brought to the planet Perelandra (our Venus), a world with completely innocent inhabitants. It is the mad human scientist, Weston, who is the vehicle for tempting the queen of the planet, Green Lady. He goes to great length to argue that she should disobey the one command from Maleldil (Perelandra's name for God) that they must never stay the night at the Fixed Island. Weston is arguing that Maleldil really intends her to disobey his commands:

'These other commands of His-to love, to sleep, to fill this world with your children-you see for yourself that they are good. And they are the same in all worlds. But the command against living on the Fixed Island is not so. You have already learned that He gave no such command to my world. And you cannot see where the goodness of it is. No wonder. If it were really good, must He not have commanded it to all worlds alike? For how could Maleldil not command what was good? There is no good in it. Maleldil Himself is showing you that, this moment, through your own reason. It is mere command. It is forbidding for the mere sake of forbidding.'

'But why ...?'
'In order that you may break it. What other reason can there be? It is not good. It is not the same for other worlds. It stands between you and all settled life, all command of your own days. Is not Maleldil showing you as plainly as $\mathrm{He}$ can that it was set up as a test - as a great wave you have to go over, that you may become really old, really separate from Him.'

'But if this concerns me so deeply, why does He put none of this into my mind? It is all coming from you, Stranger. There is no whisper, even, of the Voice saying Yes to your words.'

'But do you not see that there cannot be? He longs-oh, how greatly He longs-to see His creature become fully itself, to stand up in its own reason and its own courage even against $\mathrm{Him}$. But how can $\mathrm{He}$ tell it to do this? That would spoil all. Whatever it did after that would only be one more step taken with Him. This is the one thing of all the things $\mathrm{He}$ desires in which $\mathrm{He}$ must have no finger. Do you think $\mathrm{He}$ is not weary of seeing nothing but Himself in all that He has made? If that contented Him, why should He create at all? To find the Other - the thing whose will is no longer His - that is Maleldil's desire.' 10

Again, we are struck by Lewis' imaginative retelling of the biblical story. Thus, both examples illustrate that deep truths of the Christian worldview may be communicated powerfully through various forms of imaginative narratives.

\section{Francis A. Schaeffer on approa- ching Genesis and science}

\section{Locating Genesis in Space and Time with Schaeffer \\ Like Jack Collins, we have also been influenced by C. S. Lewis and Francis A.}


Schaeffer. Whereas Collins specifically refers to a key booklet by Schaeffer called No Final Conflict (see below), we would also like to highlight Schaeffer's book on Genesis 1-11 called Genesis in Space and Time.

In this book, the early chapters of Genesis are immediately related to the larger worldview questions:

In some ways [Genesis 1-11] are the most important chapters in the Bible, for they put man in his cosmic setting and show him his peculiar uniqueness. They explain man's wonder and yet his flaw. Without a proper understanding of these chapters we have no answer to the problems of metaphysics, morals, or epistemology, and furthermore the work of Christ becomes one more upper-story 'religious' answer. ${ }^{11}$

Schaffer claims that we should not understand the early chapters of Genesis as unhistorical myths, but as credible stories firmly located in our space and time reality. Therefore, they speak with trustworthiness and relevance to our real world.

\section{Exploring Genesis as an Explanatory Worldview Story with Schaeffer}

Schaeffer was well-known for his worldview approach in apologetics, where he contrasted a biblical worldview with alternative perspectives. This was also the case in Genesis in Space and Time. Here we will quote one of Schaeffer's classical arguments at length. The major thrust of his argumentative approach is that alternative non-Christian worldviews do not have satisfactory answers to the big questions in life:

An impersonal beginning... raises two overwhelming problems which neither the East nor modern man has come anywhere near solving.
First, there is no real explanation for the fact that the external world not only exists but has a specific form. Despite its frequent attempt to reduce the concept of the personal to the area of chemical or psychological conditioning, scientific study demonstrates that the universe has an express form. One can go from particulars to a greater unity, from the lesser laws to more and more general laws or super-laws. In other words, as I look at the Being which is the external universe, it is obviously not just a handful of pebbles thrown out there. What is there has form. If we assert the existence of the impersonal as the beginning of the universe, we simply have no explanation for this kind of situation.

Second, and more important, if we begin with an impersonal universe, there is no explanation of personality. In a very real sense, the question of questions for all generations -- but overwhelmingly so for modern man -- is, "Who am I?" For when I look at the "I" that is me and then look around to those who face me and are also men, one thing is immediately obvious: Man has a "mannishness." You find it wherever you find man -- not only in the men who live today, but in the artifacts of history. The assumption of an impersonal beginning cannot adequately explain the personal beings we see around us; and when men try to explain man on the basis of an original impersonal, man soon disappears.

In short, an impersonal beginning explains neither the form of the universe nor the personality of man. Hence it gives no basis for understanding human relationships, building just societies, or engaging in any kind of cultural effort. It is not just the man in the university who needs to understand these ques- 
tions. The farmer, the peasant, anyone at all who moves and thinks needs to know. That is, as I look and see that something is there, I need to know what to do with it. The impersonal answer at any level and at any place at any time of history does not explain these two basic factors -- the universe and its form, and the "mannishness" of man. And this is so whether it is expressed in the religious terms of pantheism or modern scientific terms.

But the Judeo-Christian tradition begins with the opposite answer. And it is upon this that our whole Western culture has been built. The universe had a personal beginning a personal beginning on the high order of the Trinity. That is, before "in the beginning" the personal was already there. Love and thought and communication existed prior to the creation of the heavens and the earth. ${ }^{12}$

We would like to suggest that this worldview approach continues to be relevant for Christian apologetics, even though it may need to be further developed, as more nuanced, specific, and contextual.

\section{Claiming No Conflict between Genesis and science with Schaeffer}

In the booklet No Final Conflict'13 Schaeffer's concern is with the trustworthiness and authority of the Scriptures over against 'neo-orthodox existentialist' theologies, where the Bible is emptied from propositional content.

The issue is whether the Bible is God's verbalized communication to men giving propositional truth where it touches the cosmos and history, or whether it is only in some sense "revelational" where it touches matters of religion. The early chapters of Genesis relate to this discussion, but ultimately the question is not (and cannot be) confined to them: the whole Bible is involved. ${ }^{14}$

If we try to separate the religious passages in the book of Genesis from those which touch on history and the cosmos, the religious passages are relegated to an upper-story situation. They have been removed from any connection to space-time verification, and that means no historical or scientific study can refute them. But it also follows that no studies can verify them. In short, there is no reason to accept the upper-story religious things either. The upper-story religious things only become a quarry out of which to have our own personal subjective, existential, religious experience. There is no reason, then, to think of the religious things as being other than in one's own head. ${ }^{15}$

Even though Schaeffer has a strong, conservative evangelical view of the Bible, he proposes an approach to Genesis 1-3 with freedoms and limitations.

In terms of "freedoms", Schaeffer lists seven possible interpretations of Genesis $1-3$, while not explicitly supporting any of them: (1) God may have created a "grown up universe". (2) There may have been a time gap between verses 1 and 2, and verses 2 and 3. (3) It is possible that Genesis 1 talk about a "long day". (4) The flood may have affected the geological data. (5) The word "kind" in Gen $1: 11$ is not synonymous with species. (6) There may have been animal death before the Fall. (7) Only the word 'bara' must imply an absolute beginning.

On the other hand, Schaeffer suggests two "limits". The first is that "the word bara insists that the original creation, at the creation of conscious life and the creation of man there was specific discontinuity with what preceded." 16 The second 
is holding that "Adam was historic and was the first man and that Eve was made from Adam." For the latter point he refers to the NT, which means that this question also involves the whole authority of the NT including Paul.

When assessing Schaeffer's approach, Collins summarizes as follows:

He has covered the main options that evangelicals in his day had explored. And surely his instincts are right... At the same time, a great deal of water has gushed on by under the exegetical bridge since his booklet first saw publication in 1975, and thus I would take his list of freedoms as enumerative and suggestive, rather than exhaustive. The limitations strike me as eminently reasonable, and indeed generous. ${ }^{17}$

Thus, this approach seeks to formulate a constructive framework for the discussion on the early chapters of Genesis which allows for different ways of interpreting, while at the same time upholding some fundamental theological commitments.

\section{The Schaeffer Legacy: The L'Abri Statement on Creation and Evolution}

The L'Abri movement has felt the impact of the ongoing discussion on Genesis and science. In 2012, the Board of Trustees felt it necessary to formulate a statement on the issue, where they attempted to formulate the legacy from Schaeffer. The statement bears quoting in full:

\section{Creation/Evolution Summary Statement}

The Creation/Evolution debate can be complex, confusing and all too often controversial. But it has nevertheless been important within L'Abri to speak to the issues invol- ved. L'Abri has in fact produced many lectures and even a few books relevant to the subject. Schaeffer himself frequently addressed the issue in a number of places, not least in his book Genesis in Space and Time. There we find a good summary of the L'Abri approach to this subject.

We note that Schaeffer does not major on attacking Evolution as a scientific system. He does not get into the biology or the fossil records, etc. Rather his focus is on drawing out the central Biblical teaching on origins and contrasting it at critical points with the paradigm that he called 'the impersonal plus time plus chance' and its implications.

His focus is on the key ideas and their consequences rather than their origins in a particular scientific theory - and he never comes across as anti-science. $\mathrm{He}$ is extremely careful to leave room for debate on issues he feels not completely clear in Scripture and yet he never loses focus on the critical importance of defending a 'space-time' Creation. So he allows freedom of opinion on the lengths of the days, on animal death before the Fall, on the extent of the flood - all of which shows him to be remarkably free of his own fundamentalist heritage.

And yet he is crystal clear that there was an historical Adam and Eve, an historical Fall, and multiple moments of creative intervention by God. The enemy for him is not necessarily evolution per se, but rather - an impersonal universe, a chance origin, the absence of the supernatural, the uniformity of natural causes in a closed system, and man as [a] biological machine. What is defended is not so much a detailed pseudoscientific Creationism but rather the critical importance of divine supernatural acti- 
vity, of design and purpose, of the image of God in Man, of human death (including physical death) as a result of God's judgment, and a real historical flow in Genesis.

These continue to be the central affirmations and denials that shape our perspective in L'Abri today. As time moves on, various interpretations of Genesis and different scientific theories will doubtless come and go. Questions about exactly how God has interacted with Creation and to what degree $\mathrm{He}$ has used secondary causes to achieve His purposes will always prove challenging. Consequently, we also want to leave room for new data and fresh perspectives arising in our own moments of history, as these may call us to re-examine our positions. But in the matter of our origins, the theological affirmations and denials listed above will remain the key convictions we will want to stand on.

L'Abri Trustees

November 30th, 201218

This statement follows Schaeffer's key approach in focusing on the major worldview issues, affirming some basic theological commitments, while leaving the discussion open on several other issues.

\section{Reading Genesis 1-3 with Jack Collins - inspired by Lewis and Schaeffer}

As a leading evangelical specialist on Genesis, Collins has contributed many academic and more popular publications on Genesis 1-3. This part of our essay will therefore be highly selective and only indicative. We will focus on the three key literary questions from Lewis and on Schaeffer's freedoms and limitations approach.

\section{Answering the first question from} Lewis: "What it is"

When it comes to identifying the literary characteristics of Genesis 1:1-2:3, Collins uses the term exalted prose narrative. The literary form is narrative, while the style or register of the narrative is exalted prose. This is based on several observations from the text, including the following:

1. The pericope consists of an almost liturgical recounting of God's achievements...

2. We have a highly patterned presentation of the days. ...

3 . The narrative is exceedingly broad in its taxonomies...

4. The name for the heavens, [raqia'], the "expanse," is unusual and probably rhetorically "high" or poetic ...

5. The sun and the moon are given very allusive names ("greater light" and "lesser light"), names that are not normal for the Bible...

6. God takes a rest on his Sabbath (but every faithful person knows that God never gets tired).

7. The events are, in the nature of the case (creation), unique, which supplies a good reason for a unique style. ${ }^{19}$

But granted that Genesis 1:1-2:3 is an exalted prose narrative, what is it all about? Collins has become well-known for his analogical day position: "The creation days are God's workdays, their length is neither specified nor important, and not everything in the account needs to be taken as historically sequential." 20

The analytical overview provided by Bruce Gordon is a succinct summary of this position and approach:

Collins argues that Genesis 1:1 is best interpreted as a summary of God's activity prior to the first day of creation in Genesis 1:3, which 
allows for an unspecified period of time to have passed prior to God's beginning to shape the earth for habitability.

Collins develops his analogical understanding in light of the following considerations: (1) the ongoing nature of the seventh "day" that lacks an evening and a morning (Gen. 2:2); (2) the expansion of the sixth "day" in the second creation account (Gen. 2:5-25); (3) a lexicogrammatical resolution of the problem of the fourth "day" in which - since God here tasks the sun, moon, and stars to govern the day and night (Gen. 1:14-16) - the Hebrew allows God's action to be that of appointing these previously created heavenly bodies (Gen. 1:1) to their function of marking time for sentient life; and (4) the poetic parallelism correlating "days" one to three as a triad with "days" four through six (the literary-framework observation), which indicates that day length and chronology are not primary considerations in the creation account. ${ }^{21}$

As an exalted prose narrative, Genesis 1:1-2:3 should not be interpreted in a literalistic way. As Collins points out in various contributions, a literalistic approach may be found within a wide spectrum of interpretations, including both creationist and theistic evolutionist readings.

Therefore, the passage in Genesis 1 should neither be read as plain history nor as ancient or modern science. This relates to our understanding of 'history' and 'historical':

We appreciate that in ordinary language to say that something is 'historical' is to say that there are actual persons and events for it to refer to and these persons and events really existed. This does not determine the literary form or rhetorical setting in which the referring takes place, however. ... Hence, we must insist that 'history' is not a literary form; it is rather a way of referring to persons and events with a proper moral orientation. ${ }^{22}$

The early chapters of Genesis have a clear historical function in this referential sense, "in the sense that it speaks of real persons and events - even if we have difficulty in locating them precisely in time and space with the tools we currently have"23. We may relate Collin's insightful analysis at this point to Schaeffer's emphasis on the necessity to locate Genesis in real space and time, but without presupposing specific chronology and / or geography.

\section{Answering the second question from Lewis: "What it was intended to do"}

Through his careful analysis of the early chapters of Genesis, Collins uncovers a dual purpose for these chapters:

I take the purpose of Genesis to begin with opposing the origin stories of other ancient peoples by telling of one true God who made heaven and earth, and who dignified humankind with a special nobility, namely, the task of ruling the world wisely and well. 24

... [The] purpose of Genesis $1-11$ is to set the stage for Genesis 12-50, and it does this by clarifying that the God who called Abraham is in fact the one true God for whom all humankind yearns. ${ }^{25}$

Based on these key insights, Collins coined the phrase "the front end of the basic worldview story". It served as the front end of the basic story for ancient Israel, and in the same way it functions as the front end of the big story that defines Christians.

This leads naturally to two questions: 
How can we summarize this story? And what was this 'front end of the basic worldview story' intended to do?

The overall story - of an initially good creation, suitable for habitation and rule by humans exercising wisdom and benevolence; the intrusion of sin into human life, spoiling and disrupting human community; the good Creator steadfastly committed to redeeming his creatures and planning how to bring restoration and eventual fulfillment to them all - this story, I say, rings true. It makes sense of Israel, and it makes sense of Jesus. It enlists you and me to live loyally toward God, to like what he likes, and to embrace our place in the community of his faithful, the community that is a place where together we aspire to be good, and also provide safety for those who aren't very good at being good, and is the key player in this unfolding story. 26

Thus, the worldview story defines and shapes the worldview community.

\section{Answering the third question from Lewis: "How it is meant to be used"}

As the front end of the big story in the Bible, Collins point out that we may identify both a social and a liturgical function of Genesis 1-11:

Its social function is to narrate prehistory and protohistory, with a view to laying the groundwork for the Pentateuch's formation of Israel's identity - to reinforce God's calling: this is who we are, this is where we come from, this is what God intends to do in us and through us; these are the things we are called upon to like and to value. The narration would most often be read aloud in the public sacred gatherings of ancient Israel, and thus also in our Christian services of worship. Its literary form is pre- dominately narrative, with styles that differ from pericope to pericope. Does it aim to tell history? Yes, in the sense that it speaks of real persons and events - even if we have difficulty in locating them precisely in time and space with the tools we currently have. ${ }^{27}$

\section{Upgrading Schaeffer's Freedoms and Limitations Approach}

It is especially in the explorations of Genesis 3 and the relationship between a historical Adam and Eve and science, that Collins has applied Schaeffer's freedoms and limitations approach. He has summarized his fundamental convictions ("limitations") in the following way:

I consider it important to protect three basic affirmations:

1) the human race is one family with a unified origin (regardless of the initial population size);

2) humans arose by a process that goes beyond the impersonal;

and

3) sin is an alien intruder into God's good creation and entered into human experience at some point in the headwaters of human history.

I say, then, that we can preserve the Big Story so long as we maintain the solidarity of the human race in Adam - both his contemporaries and those who came after him. This story has the virtues of being robust in that it can make room for scientific exploration, critical in that it guards our good sense against erroneous views, and sense giving in that it actually addresses our condition and enables us to live faithfully. 28

Thus, Collins proposes that Adam may be described as the "federal head" of humankind, uniting humans in our identity as both image bearers and rebels. 


\section{Brief, final reflections on \\ Genesis $1-3$ as a True Worldview Story}

\section{Applying James Sire's Worldview Definition to Genesis 1-3}

The understanding of Genesis 1-3 as a biblical worldview story, may be illuminated further by James W. Sire's definition of worldviews: ${ }^{29}$

A worldview is a commitment, a fundamental orientation of the heart, that can be expressed as a story or in a set of presuppositions (assumptions which may be true, partially true or entirely false) which we hold (consciously or subconsciously, consistently or inconsistently) about the basic constitution of reality, and that provides the foundations on which we live and more and have our being. ${ }^{30}$

In relation to Genesis 1-3, we may paraphrase the four central elements of this definition as follows: (1) The basic commitment expressed by the author of these chapters is a personal trust in God as Creator, Sustainer, and Lord. The desired fundamental orientation of the heart is a personal covenant relationship with this one, true God. (2) Genesis 1-3 functions as the front end of a true worldview story, told in exalted prose narrative, and was neither intended as an ordinary history nor as ancient or modern science. (3) Genesis 1-3 has a referential function and claims that the basic constitution of reality is a created universe; thus, rejec- ting both ancient and modern alternative secular and religious worldviews. (4) As a true worldview story, it provides the foundation on which we in the Christian worldview community live and move and have our being.

\section{Relating Genesis 1-3 to Paul's Apologetic Argument in Athens}

We suggest that even though this worldview approach is a modern idea conceptually, it corresponds to a large extent to key biblical models. In fact, we find that the apologetic thrust of Genesis 1-3 as a true worldview story is parallel to the initial stages in Paul's apologetic speech to the Areopagos Council in Athens (Acts 17:22-31). Paul's argumentative approach in that context, when faced with Stoicism, Epicureanism, and polytheism, was a move from natural theology through ultimate authority to the Resurrection.

The first two stages in Paul's argument was (i) that a Judeo-Christian natural theology provides the most adequate view of God, the universe and humanity in comparison with other worldviews, and (i) that the Creator and Sustainer, as the Author of life, has absolute and legitimate authority over life. This is also - in broad terms - the overall argumentative move in Genesis 1-3, over against alternative worldview stories. ${ }^{31}$ In conclusion, we suggest that a careful reading of Gen 1-3 as a true worldview story is appropriate both exegetically, theologically, and apologetically. 


\section{Notes}

1 C. John Collins, "Freedoms and limitations: C.S. Lewis and Francis Schaeffer as a Tag Team" [re-published in this issue], p. 169

2 See further https://henrycenter.tiu.edu/section/creation-project/.

3 C. S. Lewis, A Preface to Paradise Lost (Oxford: Oxford University Press, 1942), 1.

4 Jonathan Petersen, "How to interpret the Book of Genesis: An Interview with C. John Collins", BibleGateway Blog February 21, 2019) https://www.biblegateway.com/blog/2019/02/how-to-interpret-thebook-of-genesis-an-interview-with-c-john-collins/

5 Alister E. McGrath, Narrative Apologetics: Sharing the Relevance, Joy, and Wonder of the Christian Faith (Grand Rapids, MI: Baker Books, 2019), p 31.

${ }^{6}$ McGrath 2019, pp. 31-32

7 C.S. Lewis, The Discarded Image: An Introduction to Medieval and Renaissance Literature (Cambridge: Cambridge University Press, p. 174.

8 C. S. Lewis, The Magician's Nephew (New York: Macmillan, 1966), pp. 69-70.

${ }^{9}$ Lewis 1966, p. 73.

10 C.S. Lewis, Perelandra, (New York: Harper Collins, 2011), pp. 142-143.

11 Francis A. Schaeffer, Genesis in Space and Time (Madison, WI: InterVarsity Press, 1972) p. 9.

12 Schaeffer 1972, p. 21.

13 Francis A. Schaeffer, No Final Conflict. The Bible Without Error in All That it Affirms (Downers Grove,

IL: Inter-Varsity Press, 1975)

14 Schaeffer 1975 , p. 8.

15 Schaeffer 1975, p. 14.

16 Schaeffer 1975 , p. 33.

17 Collins p. 168 (in this issue).

18 www.labri.org/statements/The-LAbri-Statements.pdf

19 C. John Collins, Reading Genesis Well: Navigating History, Poetry, Science, and Truth in Genesis 1-11

(Grand Rapids, MI: Zondervan, 2018), pp. 155-156.

20 C. John Collins, Genesis 1-4. A Linguistic, Literary, and Theological Commentary (Phillipsburg, NJ: P\&R Publishing, 2006), p. 124.

21 Bruce L. Gordon, "C. John Collins", in Paul Copan et al (eds) Dictionary of Christianity and Science (Grand Rapids, MI: Zondervan, 2017), pp. 98-99.

22 Collins 2018, p. 141.

23 C. John Collins, “RIP, Genre: The Idea Has Run Its Course”, Sapientia, April 4, 2017.

https://henrycenter.tiu.edu/2017/04/genre-has-run-its-course-let-the-word-retire-in-peace

24 Collins 2018, p. 137.

25 Collins 2018, p. 138.

26 Collins 2017 in Sapientia.

27 Collins 2017.in Sapientia.

28 C. John Collins, “Adam as Federal Head”, In: Stanley P. Rosenberg (ed.) Finding Ourselves After Darwin (Grand Rapids, MI: Baker Academic, 2018), p. 4012 [Kindle loc.].

29 See Bjørn Hinderaker, "James W. Sire (1933-2018): Unlikely Academic and Humble Apologist”, Theofilos; 2018 Vol. 10 (1) pp. 78-87; Margunn Serigstad Dahle and Bjørn Hinderaker: "Livssynsteori som perspektiv ved NLA Mediehøgskolen Gimlekollen"; in: Hagesæther, Gunhild et al (eds.) NLA Høgskolen: Fagutvikling og sjølvforståing på kristen grunn (Oslo: Cappelen Damm Akademisk / NOASP, 2020), pp. 147-185. 30 James W. Sire, The Universe Next Door: A Basic Worldview Catalogue (Downers Grove, Ill.: InterVarsity Press, 2004; $4^{\text {th }}$ ed.), p 17.

31 See Lars Dahle, "Truth, Christian Mission and Apologetics: A Response and A Proposal", Norwegian Journal of Missiology 2013, vol. 67 (1), pp. 21-38. Available online at https://journals.mf.no/ntm/article/view/4285/3602. 


\title{
Four Dozen Key Resources on Apologetics and Natural Theology in an Age of Science
}

\author{
Curated and annotated by Peter S. Williams \\ Assistant Professor in Communication and Worldviews \\ NLA University College \\ peterswilliams@gmail.com
}

I was both delighted and daunted when Chief Editor Lars Dahle invited me to compile a bibliography for this special Supplement edition of Theofilos on 'Science, Natural Theology, and Christian Apologetics'.

Of course, these days a literal interpretation of 'bibliography' would preclude mentioning some of the many excellent resources available in the form of video and audio material via platforms such as the internet, and so I've chosen to provide the following list of key 'resources' under several sub-headings. Each resource is followed by a brief description.

The title of this list was inspired by Alvin Plantinga's famous paper on 'Two dozen (or so) arguments for God', with four dozen recommendations giving room for covering the wide variety of issues that fall within the remit of 'apologetics and natural theology in an age of science', without becoming too unwieldy.

Key Documentary Series:

The God Question: The Series/Science vs God? (Dir. Ian Morris.):

www.thegodquestion.tv

The website for the series provides study guides, leaders guides, and materials for schools.

See also: Peter S. Williams \& Lars Dahle, 'Turning Back the Tide of Atheism with the God Question' https://youtu.be/wBWYvCBRYYw https://foclonline.org/talk/turning-backtide-atheism-god-question

\section{Key Websites:}

Reasonable Faith Website: www.reasonablefaith.com

This leading Christian apologetics website showcases the work of William Lane Craig.
Peter S. Williams' YouTube Channel, Curated Playlists:

www.youtube.com/user/peterswilliamsvid/playlists?flow=grid $\&$ view $=1$

Over 125 curated YouTube playlists on a wide variety of apologetic and philosophical subjects.

\section{Key Podcasts:}

Reasonable Faith Podcast: www.reasonablefaith.org/media/reasonable-faith-podcast/

William Lane Craig's interview style podcast.

Unbelievable? www.premierchristianradio. com/Shows/Saturday/Unbelievable

In this program from Premier Christian

Radio, Justin Brierley ably hosts discus- 
sion between guests with differing ideas about important issues.

The Peter S. Williams Podcast: http://podcast.peterswilliams.com

This apologetics podcast often covers issues related to science, natural theology, and Christian apologetics

\section{Key Texts:}

Barrett, Matthew, Ardel B. Caneday and Stanley N. Gundry ed.'s. Four Views On The Historical Adam (Zondervan, 2013)

Denis O. Lamoureux, John H. Walton, C. John Collins and William D. Barrick have a four-way discussion about how to understand the Biblical figure of Adam.

Bassham, Gregory ed. C.S. Lewis's Christian Apologetics: Pro and Con (Brill/Rodopi, 2015)

A series of short debates over arguments drawn from the works of C.S. Lewis. The debate between Bassham and Peter S. Williams over the argument from desire is continued by the latter in "In Defence of Arguments From Desire" (2016) www.peterswilliams.com/2016/11/02/ in-defence-of-arguments-from-desire/.

Blomberg, Craig and Carl Stecher, with contributions by Richard Carrier and Peter S. Williams, Resurrection: Faith or Fact? A Scholars' Debate Between a Skeptic and a Christian (Pitchstone, 2019)

This written debate on the resurrection is the only such volume published by a non-Christian publisher. See also:

Peter S. Williams, 'Resurrection:

Faith or Fact? Miracle Not Required?'

Theofilos vol.11, nr 2 (2019)

https://theofilos.no/wp-content/uploads/ 2020/03/Theofilos-vol.-11-nr.-2-2019-

Forum-3-Arkiv.pdf.

Copan, Paul and William Lane Craig, ed.'s. The Kalam Cosmological Argu- ment, Volume 2: Scientific Evidence

for the Beginning of the Universe

(Bloomsbury Studies in Philosophy of

Religion, 2019)

This collection of papers reviews and assesses the latest scientific evidences for the universe's beginning and ends with an examination of the kalam argument's conclusion that the universe has a cause - a personal cause with properties of theological significance.

Copan, Paul and Charles Taliaferro, ed.'s. The Naturalness of Belief:

New Essays on Theism's Rationality

(Lexington, 2018)

Beginning with naturalist Graham Oppy's own account of the naturalness of a naturalistic worldview, this wideranging collection of papers defends the naturalness of theism in light of consciousness, intentionality, beauty, human dignity, free will, rationality, and knowledge; as well as looking at commonsensical, existential, psychological, and cultural reasons, in addition to insights from the cognitive science of religion.

Copan, Paul et al ed.'s. Dictionary of Christianity and Science (Zondervan, 2017)

Billing itself as "The definitive reference for the intersection of Christian faith and contemporary science", this multiauthor work by over 140 leading international scholars includes "Multipleview essays on controversial topics" and entries on over 450 key terms, theories, individuals and subjects of debate.

Copan, Paul and Paul Moser, ed.'s. The Rationality of Theism (Routledge, 2003)

A good collection of introductory/intermediate level papers. Part One addresses foundational issues about religious language and epistemology. Part Two focuses on arguments for God's existence, including the ontological argument, the cosmological argument, the teleological argument, and miracles. In Part Three examines arguments 
against theism from the divine attributes and the existence of evil.

Cowen, Steven B. ed. Five Views on Apologetics (Zondervan, 2000)

Brings leading exponents of five different apologetic methodologies into dialogue.

Craig, William Lane. On Guard for Students: A Thinker's Guide to the Christian Faith (David C. Cooke, 2015)

The foremost apologist of our times writes an accessible book aimed at non-Christian readers.

Craig, William Lane and J.P. Moreland ed.'s. The Blackwell Companion to Natural Theology (Wiley-Blackwell, 2009)

Substantial essays on different aspects of natural theology written by leading philosophers.

Craig, William Lane and J.P. Moreland ed.'s. Naturalism: A Critical Analysis

(Routledge, 2014)

A stellar collection of papers that put the debate about theism in the context of arguments against metaphysical naturalism.

Dembski, William A. and Jonathan Wells. The Design of Life: Discovering Signs of Intelligence in Biological Systems (ISI, 2007)

An engaging intermediate level introduction to intelligent design theory within the biological sciences.

Gordon, Bruce L and William A. Dembski, ed.'s. The Nature of Nature: Examining the Role of Naturalism in Science (ISI, 2010)

A large collection of papers, from different perspectives, on naturalism in science.

Gundry, Stanley N. and J.B. Stump ed.'s. Four Views on Creation, Evolution, and Intelligent Design (Zondervan, 2017)
Representatives from Answers in Genesis, Reasons to Believe, BioLogos and the Discovery Institute dialogue over their different models of origins.

Hannam, James. The Genesis of Science: How the Christian Middle Ages

Launched the Scientific Revolution

(Regnery, 2011)

Sets straight the record about the relationship between Christianity and science in the middle ages.

Holder, Rodney. Ramified Natural Theology in Science and Religion:

Moving Forward from Natural

Theology (Routledge, 2021)

Uses Bayesian confirmation theory to defend a 'ramified natural theology' in dialogue with both science and historical-critical study of the Bible.

Kitchen, K.A. On the Reliability of the Old Testament (Eerdmans, 2006)

A robust defence of the historical reliability of the Old Testament by an eminent Egyptologist.

Larmer, Robert A. The Legitimacy of

Miracle (Lexington, 2014)

A brilliant philosophical defense of miracles.

Lennox, John C. God's Undertaker: Has Science Buried God?, second edition (Lion, 2009)

A winsome rejection of the popular idea that modern science has "buried" God.

Licona, Michael R. The Resurrection of Jesus: A New Historiographical Approach (IVP/Apollos, 2010)

This substantial monograph by a protégé of Gary R. Habermas leans over backwards to avoid confirmation bias and is noteworthy for its careful discussion of historical methodology.

Menuge, Angus. Agents under Fire: Materialism and The Rationality of Science (Rowman \& Littlefield, 2004) 
Philosopher Menuge relates intelligent design theory to the philosophy of mind, arguing that irreducible complexity challenges reductionist accounts of human psychology as well as reductionism in biology.

Meyer, Stephen C. The Return of The God Hypothesis: Three Scientific Discoveries Revealing the Mind Behind The Universe (HarperOne, 2021)

Philosopher of science and leading intelligent design theorist Stephen C. Meyer mounts an argument for theism.

Miller, Corey and Paul Gould, ed.'s. Is Faith in God Reasonable? (Routledge, 2014)

Begins with the transcription of a debate between William Lane Craig and Alex Rosenberg, adds several commenting papers, and gives the debaters the opportunity to respond.

Monton, Bradley. Seeking God in Science: An Atheist Defends Intelligent Design Theory (Broadview Press, 2009)

Atheist philosopher of science Bradley Monton defends the scientific status of intelligent design theory and explains why its arguments make him less certain of his atheism.

Moreland, J.P. The Recalcitrant Imago Dei: Human Persons and the Failure of Naturalism (SCM, 2009)

A leading Christian philosopher, Moreland mounts a wide-ranging argument against naturalistic accounts of human beings.

Moreland, J.P. Consciousness and the Mind of God (Routledge, 2008)

Moreland is a leading proponent of the theistic argument from mind.

Moreland, J.P. Scaling the Secular City: A Defence of Christianity (Baker, 1987)

One of the finest one-volume apologetics of the twentieth century.
Moreland, J.P. and William Lane Craig.

Philosophical Foundations for a

Christian Worldview, second edition

(IVP, 2017)

Moreland and Craig join forces to write a high level 'introduction' to philosophical issues relevant to forming a synoptic Christian worldview. Includes chapters on arguments for God.

Moreland, J.P. and Kai Nielsen et al. Does God Exist?: The Debate Between Theists and Atheists (Prometheus, 1993)

An interesting if somewhat frustrating debate between Moreland and Nielsen. On the atheist side, there are also contributions from atheists Antony Flew and Keith Parsons; but the real value of this collection lies in William Lane Craig' incisive debate analysis, Dallas Willard's classic 'Language, Being, God, and the Three Stages of Theistic Evidence' and Peter Kreeft's introduction, concluding chapter and appendix - all designed to help readers decide for themselves whether God is fact or fantasy.

Nagasawa, Yujin. The Existence of God: A Philosophical Introduction (Routledge, 2011)

Leading philosopher of religion Yujin Nagasawa takes the arguments for God seriously in this well written introductory work suitable for undergraduates.

Nagel, Thomas. Mind \& Cosmos: Why the Materialist Neo-Darwinian Conception Of Nature Is Almost Certainly Wrong (Oxford, 2012)

A leading atheist philosopher of mind, Nagel made waves with this short book in which he critiques the orthodox naturalistic worldview of contemporary Western culture, says nice things about the proponents of Intelligent Design theory, discusses the problems of fitting consciousness into a naturalistic ontology, and hopes vaguely for a nontheistic teleological alternative. 
Plantinga, Alvin. Where the Conflict

Really Lies: Science, Religion, and

Naturalism (Oxford University Press, 2012)

Leading Christian philosopher Alvin Plantinga argues that science and theistic religion in concord, whereas science and naturalistic atheism are in conflict.

Polkinghorne, John C. Belief in God in an Age of Science (Yale, 2003)

Quantum physicist turned theologian John Polkinghorne's Terry Lectures focus on the collegiality between science and theology.

Ratzsch, Del. Science \& Its Limits: The Natural Sciences in Christian Perspective, second edition (IVP, 2000)

An accessible introduction to the philosophy of science.

Sennett, James F. and Douglas Groothuis, eds. In Defence of Natural Theology: A Post-Humean Assessment (IVP, 2005)

Collection of papers written in the light of David Hume's influential critique of natural theology.

Smart, J.J.C. and J.J. Haldane. Atheism \& Theism, second edition (Blackwell, 2003)

A wide-ranging written debate between two noted philosophers.

Swinburne, Richard. The Existence of God, second edition (Clarendon Press, 2004)

A pioneering inductive approach to natural theology from a leading Christian philosopher of religion.

Swinburne, Richard. The Resurrection of God Incarnate (Clarendon Press, 2003)

Swinburne applies his inductive approach to defending the resurrection of Jesus.

Walls, Jerry L. and Trent Dougherty ed.'s, The Plantinga Project: Two Dozen (Or So) Arguments for God (Oxford
University Press, 2018)

Papers from an academic conference inspired by Alvin Plantinga's seminal 1986 paper on "Two Dozen (Or So) Arguments for God", highlighting the breadth of contemporary natural theology.

Williams, Peter S. Outgrowing God? A Beginner's Guide to Richard Dawkins and the God Debate (Cascade Books, 2020)

Written in dialogue form, this response to atheist Richard Dawkins' book Outgrowing God encourages critical thinking about Professor Dawkins' arguments concerning God, Jesus, and the Bible. Several chapters interact with Dawkins on issues of science and natural theology, covering the moral argument, arguments from design in biology and cosmology, and the kalam cosmological argument.

Williams, Peter S. Getting at Jesus:

A Comprehensive Critique of Neo-Atheist Nonsense about the Jesus of History (Wipf and Stock, 2019)

This "comprehensive critique" of New Atheist views on the historical Jesus and the historical testimony concerning his life, death and resurrection draws on philosophy, history, archaeology and other scientific evidence to make a positive case for the Christian understanding of Jesus. It also shows how statements from neo-atheists can be used to defend the major elements of this understanding.

Williams, Peter S. A Faithful Guide to Philosophy: A Christian Introduction to the Love of Wisdom, reprint edition (Wipf and Stock, 2019)

This well-received Christian introduction to philosophy includes an unusually broad range of material on natural theology and a chapter on the relationship between science and theology. This reprint edition includes a new author's preface and a foreword by Angus Menuge. 


\title{
How convincing is the case for God? The Finnes Gud? television series offers you the chance to assess it! 1
}

\author{
Iain Morris \\ Executive Director and Producer \\ Kharis Productions, Hamilton, Scotland \\ iain@kharisproductions.com
}

There are times in life when one is conscious of a 'wake-up call'. I seem to encounter them quite regularly and they tend to impact my life and my priorities.

One memorable example was the first time I encountered Richard Dawkins on television. In a series on prime time on the UK's Channel 4, he presented a series called The Root of All Evil? While the Bible claims that the root of (all kinds of) evil is the love of money, Dawkins implied it was religion - Christianity included. According to Dawkins, the insistence on there being a God is Medieval - fit only for a time when we had a more primitive understanding of science. Can there be anything more damaging than substituting science with magic? Can there be anything more destructive of intelligence and civilisation than teaching innocent children that there is a creator God who intended to bring the universe into existence - especially since we can show it achieved that all by itself!

What amazed me about this Dawkins TV series is that it broke all the rules of balanced broadcasting. Interviews that had been conducted with Christian theologians and/or scientists, ended up in the trash bin.

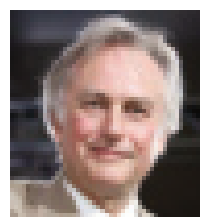

Richard Dawkins, arch opponent of religion.

Because of that indirect encounter, I went on to produce a TV series called The God Question. It is available with Norwegian subtitles as Finnes Gud? More in a moment.

Richard Dawkins has been a major catalyst in convincing wavering minds that belief in God involves being anti-intellectual and anti-science. In other words, to be a believer is to say farewell to your brain! Even though some claim that the New Atheism movement now has a diminished presence, it has a formidable continuing popular legacy. And Dawkins has a new audience in mind: children and young people. His latest book is for them - Outgrowing God.

So is there any response needed? Isn't it better that Christians ignore the issue and just go on living and preaching the Gospel? Then the problem might just go away! 


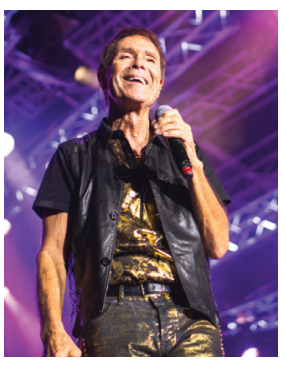

Sir Cliff Richard OBE Credit: Raph_PH, Creative Comm

Let me return to the subject of wake-up calls. On the evening before writing this article, I watched a TV interview with Cliff Richard. In it, there was reference to the fact that he is very open about his Christian faith, and has been since 1985, when he appeared at a Billy Graham meeting in Sheffield, England. In the course of discussing the problems that might have caused, a number of concerned friends appeared on screen confessing that they had been sure that such openness about Christian faith would cause Cliff's career to come to a sudden end. My wake-up call was that they should assume so.

Is being a Christian now really perceived as weird? Could it even be dangerous? Might it be a career killer? How far we have come from the point where our civilisation was known as Christendom! Yes, a response is needed. So very much needed! And the response we need is to evaluate the evidence as objectively as possible. Religious belief should not be based only on culture or historical tradition but on showing that belief is founded on good evidence. One might wish to claim that Christianity is the best explanation in the world about why we exist, but without being able to supply evidence it is harder to make the case. Evidence stands up if it survives being put to the test.

$* * *$

And that takes us to The God Question series: Finnes Gud? as it is known in Norway.

As a TV producer and director, programmes have become my favoured communication medium. What if we were to assemble on TV the world's most renowned believers alongside the world's most outspoken atheists? What if we took them on three crucially important journeys in which all on the journey exploded with wonder and then posed the question how all this can be explained? What would the result be? Would the finger of evidence point towards our existence emerging from an accumulation of

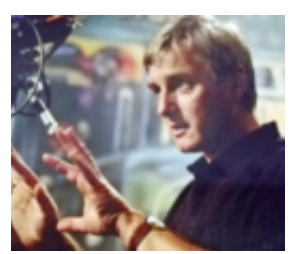

TV Director Iain Morris at work chance events in the cosmos and on earth or is the better explanation that we are the result of an intelligent mind, a creator? But where should we take our illustrious cast?

Programme 1, after setting out the ongoing conflict between the theist and atheist worldviews, blasts off into the cosmos. There our expert travellers tell the fascinating scientific story of the origins of the universe: every

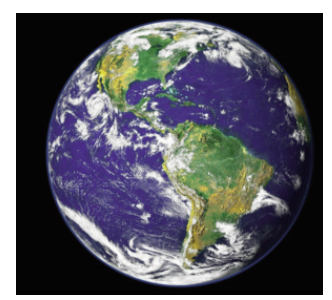
quark and atom that would ever exist was somehow represented in a dot you would not

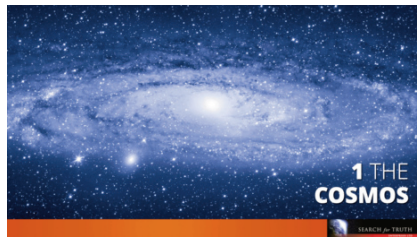

Programme 1: The Cosmos have been able to see! And then it grew, in what is termed the Big Bang. Of course the normal outcome of an explosion is chaos. But not so here.

In the first three minutes of the life of the newly born universe, 
elements crucial for its onward development began to form. Helium and hydrogen - fundamental to light and water and life - arrived! The split second timing (three minutes, not more not less) was vital to getting the balance right. And spread over billions of years the creative process continued. Out of gas and dust left over from the Big Bang, stars and planets began to form. In our solar system, $99.9 \%$ of the raw material was absorbed to form the sun. That left $1 \%$ for the formation of the planets including earth, from where we now look out, marvel and ask big questions about how and why.

Naturally, we look to science to reveal how but it cannot explain why. We must use our reasoning faculties for that. Was it all blind chance or is this real evidence for a mind behind the universe? How much faith does it take to believe in chance? Some argue that the force shaping the creativity of the universe is the laws of physics. But doesn't that beg the question: where did they come from? And there's more. For life to be sustained in the universe, finely tuned forces are required. The fine tuning in some cases is to at least 56 decimal places. Incredible! To believe in the creator in the face of such evidence is not to deploy magic; it is to accept the only reasonable and rational explanation we have! Of course, we must listen to the atheist reasoning on this too. Can the concept of 'multiverse' convince us that we really are just products of chance? That decision is for viewers to make.

Programme 2 brings us back to earth where the big question is: can the wonder of life itself - as well as the unique features of its host planet - be more convincingly explained as chance or a creator's intention? Atheists enter this fray in more confident mood. Has not Charles Darwin in his On the Origin of Species explained all we need to know about the development of life on earth

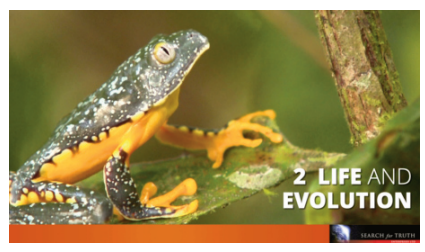

Programme 2: Life and Evolution through 'random mutation and natural selection'? One might argue that it takes substantial faith to accept that a mindless process can eventually arrive at something as sophisticated as the human mind! The issue here is not whether evolution is a 'true' account of the development of life on earth but whether such a system could work without a creator's involvement - even though we may be unclear about what that involvement precisely is.

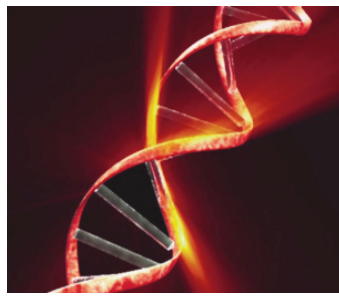

The mindless chance explanation is further challenged by the realisation that at the heart of life is the DNA code: 3 billion letters that combine in various ways to form the instruction book that builds living things. Within species those living things are essentially the same - otherwise community would not be possible, but the system also cleverly creates individuality. So we are, necessarily, the same but wonderfully individualistic too! Amazing!

$* * *$

And let's not forget that the mystery and the wonder of life itself is so far unexplained. So too is why planet earth should have so many life-encouraging properties - such as 
the phenomenon of water and a climate that protects and feeds life.

And so, the bank of evidence, to be weighed and assessed, builds.

$* * *$

Programme 3 takes us on the final journey - into the depths of the human mind and brain. It is the story of human consciousness. Here we truly are in the presence of instruments of wonder: the intricacies of the thought process, of language, of body co-ordination. But there is more. The mind and brain are capable of recognising beauty, of being creative and of problem solving and of

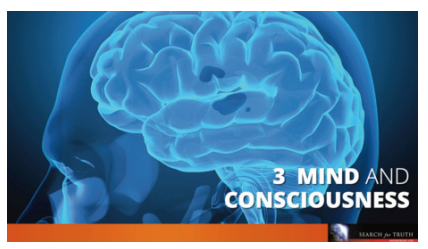

Programme 3: Mind and Consciousness making moral choices and distinctions between right and wrong. How can this be explained in purely evolutionary terms?

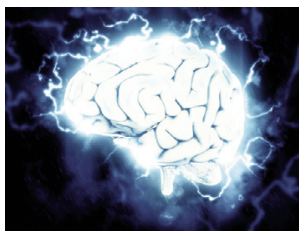

Programme 3: A human brain

Ultimately those same cerebral instruments, for most people across the world, sense a presence outside of themselves that we might call 'God'. Is this wishful thinking or might it be that humans are hard wired by their creator to make the ultimate connection? And if the connection is made, is there any evidence of impact? Personal testimonies supply some evidence to be pondered. By now we have gone beyond science, but to science we return, in order to investigate a world wide experiment taking place to test if human consciousness continues after the point of clinical brain death. The results are fascinating.

And so the jury is called once more to assess if there is a rational case to be made for a mind behind such sophisticated wonder.

$* * *$

Accompanying the series is a study guide that helps viewers absorb and remember the content of the programmes. Here they also receive summaries of The Case for Theism and The Case for Atheism as well as find a range of questions that help them to evaluate the evidence.

The question of God's existence is often decided (for believers and non-believers) on the basis of intuition, culture or peer group influence. Finnes Gud? offers an evidencebased opportunity to understand the issues.

Since its release, The God Question has been shown on scores of TV channels across the world with millions having had the opportunity to view it in their own language. NRK in Norway was the second European channel to acquire it, after SVT in Sweden. The series has been shown in universities and in schools, in churches and in homes. There are many reports of how it has strengthened belief and challenged scepticism.

For those who prefer a 'fast track' approach, a new version called The God Question for Starters has recently been produced. There are ten extracts

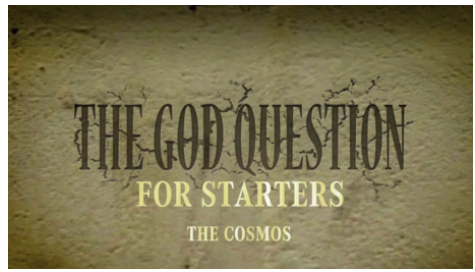


of 3-5 minutes for each of the three programmes, with an on-screen question at the conclusion of each extract. This is also available with Norwegian subtitles.

In Outgrowing God, Richard Dawkins argues that belief in a creator is a childish thing that should be naturally abandoned by thinking people. Thinking is integral to The God Question series. Perhaps he should 'think again'!

Especially now that The God Question series is

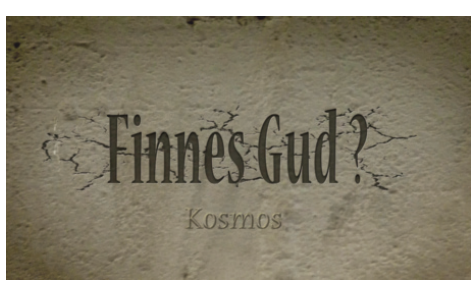
available with subtitles in Norwegian, take advantage! Assemble a group from your church to view and discuss; provide a copy for your local high school; use the series with your church youth group; gift a copy to friends or contacts who are sceptical about belief in God. The best way for them to decide is to consider the evidence.

1 For introduction, key resources, and access to the Finnes Gud? version with Norwegian subtitles, see https://finnesgud.no. The original version is introduced at http://www.thegodquestion.tv/. 


\section{Finnes Gud? Science, God and the search for truth}

Join a cast of experts debating evidence for God's existence as they:

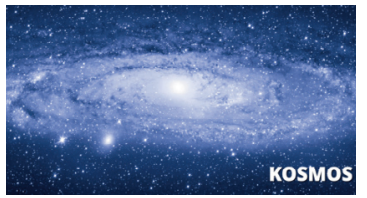

- journey into the cosmos

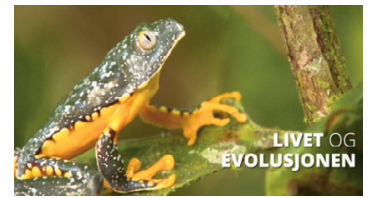

- explore the wonders of life

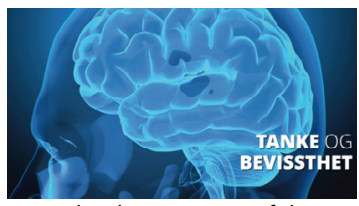

- probe the mysteries of the human mind and brain
"Superb programmes for all who want to understand why Christianity is a better and more convincing explanation of our existence than atheism." Professor John Lennox, The University of Oxford
"Every believer and non-believer should see this excellent series that addresses the most important questions of life."

Dr Greg Pritchard, Director European Leadership Forum

Order with Norwegian subtitles from www.finnesgud.no

\section{The God Question for Starters}

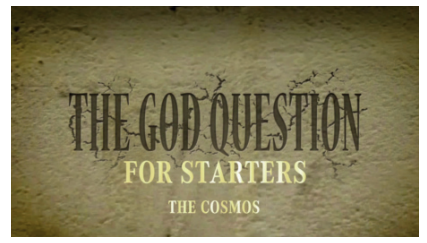

- Take the 'fast track' version of the Finnes Gud? series with ten short excerpts per programme

- Perfect for all who wish to take the Science and God question journey more quickly

- Ideal for younger teenage viewers and those in a hurry to learn

"A wonderful new resource to equip Christians to answer the questions people are asking."

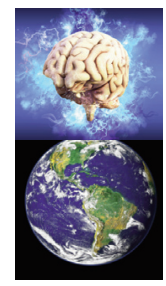
Rev Dr Fergus Macdonald, Former General Secretary, United Bible Societies.

"Nothing better for stimulating debate about the big issues in life."

Dr Liam Fraser, Campus Minister, The University of Edinburgh.

Order with Norwegian subtitles from www.finnesgud.no

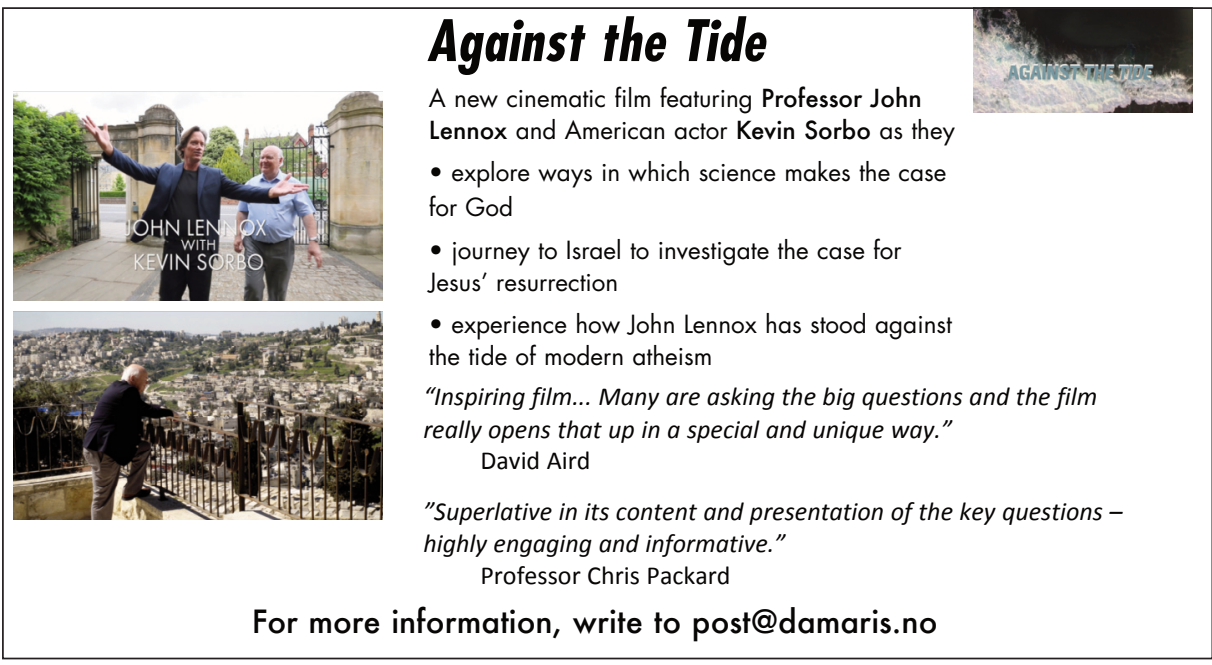




\section{Outgrowing God? A Beginner's Guide to Richard Dawkins and the God Debate \\ (Cascade Books, 2020)}

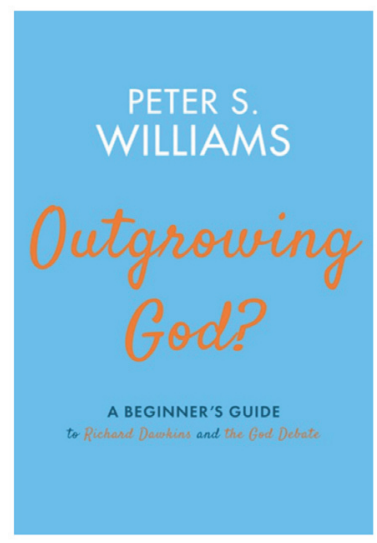

Outgrowing God? A Beginner's Guide to Richard Dawkins and the God Debate (Cascade, 2020) is a response to atheist Richard Dawkins' book Outgrowing God: A Beginner's Guide (2019). Join a cast of characters, with different perspectives, thinking through some of the biggest questions in life, as they discuss atheist Richard Dawkins' book Outgrowing God: A Beginner's Guide.

Written in the form of a dialogue between members of a student book club, Outgrowing God? A Beginner's Guide to Richard Dawkins and the God Debate encourages critical thinking about Professor Dawkins' arguments concerning God, Jesus, and the Bible.

'[a] delightful dialogue/critique of one influential atheist's philosophy...'

- Craig L. Blomberg, Distinguished Professor of New Testament, Denver Seminary

'Excellent work . . engaging, interesting and insightful.'

- Dr Lars Dable, Associate Professor in Systematic Theology and Christian Apologetics at NLA University College, Norway

'an important and insightful book... I highly recommend it.'

- J.P. Moreland, Distinguished Professor of Philosophy, Biola University

'provides many stimulating arguments on an introductory, easy-to-understand level... tackling decisive philosophical, theological, historical and scientific arguments, and providing many useful resources...'

- Martin Heide, Professor of Semitic Languages, Phillip University in Marburg, Germany

Review copies can be ordered from https://wipfandstock.com/outgrowing-god.html

Kindle or paperback from www.amazon.com

For more information and related resources, including video and audio materials, visit: www.peterswilliams.com/publications/books/outgrowing-god/ 


\section{To the contributors}

Theofilos welcome contributions to academia, forum and biblos in the fields of Theology, Philosophy, and Culture, and their neighbouring disciplines.

Contributions should be of high quality and relevant for the overall purpose of the journal, i.e. to present, analyse, and discuss the credibility and relevance of the Christian faith.

All manuscripts submitted to academia should not have been published elsewhere and should not be under consideration for publication elsewhere without the consent of the editors.

Theofilos does not charge any fees for receiving, assessing, processing, and publishing articles.

\section{academia}

Manuscripts submitted to academia should constitute a unique contribution to the academic debate within a field of study with relevance for the overall purpose of Theofilos.

Authors are asked only to submit academic texts that they consider complete with respect to content, language and format. Texts in academia should be written in Norwegian, Swedish, Danish, or English, and should usually be no shorter than 4.000 words and no longer than 9.000 words.

All research articles that are considered relevant for publication in academia are reviewed by at least two anonymous academic referees with no ties to the author. In addition, the article is reviewed by the editors and / or the journal's editorial board. The final decision regarding publication of the article is made by the Chief Editor. The journal practices double blind peer review, whereby both reviewers and the author remain anonymous to each other.

\section{forum and biblos}

The contributions to forum consist of essays, critical discussions, analysis, book review articles, and other relevant texts. These texts are not peer reviewed. They should be of the same general quality as in academia but may vary in terms of genre. In forum articles, the authors should seek to avoid specialist and technical language and aim for a broader audience.

The biblos section consists of book reviews. They should normally not exceed 6.000 characters (including space) and should contain critical assessments of the book in question.

\section{Formalia}

For more specific instructions to authors, see https://theofilos.no/authors-guidelines/.

\section{International standards}

Theofilos is committed to international professional and ethical standards for research and publication.

The journal is guided by the Principles of Transparency and Best Practice in Scholarly Publishing (Directory of Open Access Journals [DOAJ] \& Committee on Publication Ethics [COPE]) and the Guidelines for Research Ethics in the Social Sciences, Humanities, Law and Theology (The Norwegian National Research Ethics Committees).

For more information and references, see https://theofilos.no/open-access/.

\section{Theological basis and academic freedom}

The Apostles' Creed and the Lausanne Covenant constitute the theological basis for Theofilos. Whereas this confessional orientation guides the Editors and the Editorial Board, the opinions and conclusions published in Theofilos are solely those of the individual authors and do not necessarily represent the positions of the journal or the two sponsoring institutions.

\section{Academic recognition}

Theofilos is authorized as a publication channel on level 1 in NSD - Norwegian Centre for Research Data (for Norway and Sweden). 
Returadresse:

Theofilos, NLA Høgskolen

Gimlekollen

Bergtoras vei 120

NO-4633 Kristiansand, Norge

\section{Theofilos Supplement vol. 12 nr. 12020}

\section{intro}

Welcome to the first open access issue of Theofilos Stefan Lindholm .........................1 Introducing the Theofilos Supplement issue on Science, Natural Theology, and Christian Apologetics Peter S. Williams ...................................2

\section{academia}

Approaching Genesis and science: Hermeneutical principles and a case study Jens Brumn Kofoed 4

The origin of sin - in dialogue with natural science Gunnar Innerdal ......................24

The apologetic fruitfulness of a revised natural theology Knut-Willy Scether ...........46 How to formulate the fine-tuning argument for the existence of God? Atle Ottesen Søvik 56

Intelligent design and natural theology Steinar Thorvaldsen. .66

Scientific rebuttals to 'ancient aliens' as popular alternatives to biblical history

Peter S. Williams

'Unraveling the Mystery': Assessing The Big Bang Theory as a Secular

Fictional Universe Ingvild Thu Kro and Margunn Serigstad Dable. 114

\section{forum}

Natural Theology and Science in Contemporary Apologetic Context:

An Overview Peter S. Williams

Science and Faith: Friendly Allies, Not Hostile Enemies John Lennox

Freedoms and Limitations: C. S. Lewis and Francis Schaeffer as a Tag Team

C. John ("Jack") Collins

Exploring Genesis 1-3 as a True Worldview Story: Reading alongside C. S. Lewis, Francis A. Schaeffer, and C. John Collins Bjørn Hinderaker and Lars Dable .......184 